\begin{abstract}
UNIVERSIDADE DE SÃO PAULO - USP
INSTITUTO DE ELETROTÉCNICA E ENERGIA - IEE PROGRAMA DE PÓS-GRADUAÇÃO EM ENERGIA - PPGE
\end{abstract}

\title{
AVALIAÇÃO DA MONOCULTURA DE SOJA COMO MATÉRIA-PRIMA PARA A PRODUÇÃO DE BIODIESEL E SUA RELAÇÃO COM O DESMATAMENTO DA FLORESTA AMAZÔNICA: ESTUDO DE CASO NA REGIÃO DE SÃO JOSÉ DO XINGU (MT)
}

Mariana Soares Domingues

São Paulo

2010 
MARIANA SOARES DOMINGUES

\section{Avaliação da monocultura de soja como matéria- prima para a produção de biodiesel e sua relação com o desmatamento da Floresta Amazônica: Estudo de Caso na região de São José do Xingu (MT)}

Dissertação apresentada ao Programa de PósGraduação em Energia do Instituto de Eletrotécnica e Energia da Universidade de São Paulo para obtenção do título de Mestre em Ciências.

São Paulo

2010 


\section{AUTORIZO A REPRODUÇÃO E DIVULGAÇÃO TOTAL OU PARCIAL DESTE \\ TRABALHO, POR QUALQUER MEIO CONVENCIONAL OU ELETRÔNiCO, PARA FINS DE ESTUDO E PESQUISA, DESDE QUE CITADA A FONTE.}

\section{FICHA CATALOGRÁFICA}

Domingues, M, S; 2008.

Avaliação da Monocultura de Soja como Matéria-prima para a Produção de Biodiesel e sua Relação com o Desmatamento da Floresta Amazônica: Estudo de Caso na Região de São José do Xingu (MT)/

Mariana Soares Domingues; orientador Célio Bermann - São Paulo, 2010.

Dissertação (Mestrado - Programa de Pós-graduação em Energia) PPGE do Instituto de Eletrotécnica e Energia da Universidade de São Paulo.

1. Biodiesel; 2. Energia; 3. Soja; 4. Floresta Amazônica.; 5. Desmatamento;

6. São José do Xingu; 
À minha filha, Pandora. 


\section{AGRADECIMENTOS}

Embora essa dissertação tenha sido construída a partir de um trabalho individual, várias pessoas contribuíram para que esse trabalho fosse realizado. É nesse sentido que quero aqui expressar meus sinceros agradecimentos.

Agradeço ao Programa de Pós-graduação em Energia (PPGE) e ao Instituto de Eletrotécnica e Energia (IEE) que viabilizaram a realização dessa dissertação. Assim como, agradeço a Fundação Heinrich Böll pelo apoio financeiro que permitiu que a pesquisa de campo pudesse ser realizada. Ao Instituto Henfil, que me cedeu alguns dias para que o campo pudesse ser realizado.

Agradeço ao meu orientador Prof. D. Célio Bermann pelas horas de atenção, compreensão e pela paciência durante a realização dessa dissertação. Obrigada Professor! Agradeço, também, ao Prof. Dr. Murilo Werneck Fagá, Profa. Dra. Virginia Parente e Profa. Dra. Patrícia Mattai pelo apoio e estímulo prestado, valorizando esse trabalho.

Agradeço às entidades públicas que me atenderam tão amigavelmente em São José do Xingu (MT) e pelas informações prestadas: ao Sr. Gilberto Mendes, prefeito do município; Sr. Alcides, secretário da agricultura da prefeitura; Sr. Emanuel Martins, técnico agrícola do Empaer; e Sr. Elmídio e Sr. Smith, técnicos do INDEA (MT).

Agradeço aos estabelecimentos privados que me receberam tão bem e forneceram informações tão importantes para realização desse trabalho: ao Sr. Aires, Sra. Marta, Sr. Clésio, Sr. Usias, Sr. Camilo, Sr. Cássio, Sr. Leandro. Agradeço aos colegas de São José do Xingu e arredores que me encorajaram a manter a viagem, me ensinando sobre um mundo longínquo e desconhecido.

Agradeço aos meus amigos que me prestaram apoio técnico: ao Daniel, que me ajudou com toda boa vontade na elaboração dos mapas; ao Marcão, que me emprestou o GPS para o campo; à tia Chris, que me cedeu sua máquina fotográfica e sua amizade imensa; à Rúbia e Fernando, que colaboraram com seus conhecimentos no Laboratório de Sensoriamento Remoto; ao Balloo (Queridão), que tornou viável meu sonho de mestrar no IEE após uma dica especial; ao Rodolfo, que me auxiliou no inglês. Obrigado a todos pela troca de suas experiências comigo!

Agradeço, sinceramente, aos amigos que me valorizaram imensamente ao verificar meu esforço diante tantos desafios: ao Luis e Luana, casal luz; à Nice e Guilherme, meus "pais" postiços; à Luciana, minha amiga desde estagiária à profissional; à Cristiane, pela 
afinidade geográfica, ao Paulo Baco, pela amizade; ao Sérgio, por ter me acompanhado em parte desse trabalho.

Agradeço aos meus amigos do IEE, que tornaram essa passagem mais prazerosa e alegre: Luis Marcelo, Tina, Bruno, Ariel, Marcela, André, Aires e Bernal Todos me prestaram favores inúmeros e trocas valorosas para elaboração dessa dissertação e outros trabalhos.

Agradeço à família: às minhas primas Raíssa e Thaís, minhas parentes mais próximas para os "causos” familiares; às minhas irmãs Jéssica e Vitória, por serem somente lindas irmãs; à Marisa, por ter me orientado na infância.

Agradeço ao Paulinho, meu companheiro, que me valorizou e acreditou em mim e no meu potencial, estimulando meu sucesso. Além de sua ajuda em momentos muito ruins da minha vida. Obrigada pelo carinho comigo e com minha filha.

Agradeço, em especial, aos meus pais, Sr. Walter Domingues, pelo apoio emocional em toda minha vida, e Sra. Denardia Soares, pelo apoio financeiro em toda minha educação. Esse trabalho só foi possível com a insistência e presença contínua de vocês em meus estudos. Obrigada por minha educação e pelo respeito perante minhas decisões e caminhos de vida.

Agradeço à minha filha, Pandora Soares Oliveira, minha razão única de viver e que me dá coragem para lutar por um futuro melhor. Agradeço à minha fiel escudeira, Gisele, que me deu confiança e cuidou da minha pequena e da minha casa enquanto me dedicava aos estudos e a o trabalho.

A todos agradeço, profundamente.

Muito Obrigada! 


\section{RESUMO}

DOMINGUES, M.S. Avaliação da monocultura de soja como matéria-prima para a produção de biodiesel e sua relação com o desmatamento da Floresta Amazônica: Estudo de caso na região de São José do Xingu (MT). 2010. Dissertação de Mestrado. Programa de Pós-graduação em Energia, Instituto de Eletrotécnica e Energia, Universidade de São Paulo.

Esta dissertação analisa a produção de biodiesel de soja no país e sua relação com o desmatamento da Floresta Amazônica. Tendo como referência o Programa Nacional de Produção e Uso de Biodiesel - PNPB, criado em 2004 no intuito de promover a inserção de biodiesel ao diesel comum, diminuindo a dependência externa do petróleo importado e agregando valor às produções do campo, verifica-se que, a matéria-prima principal de produção de biodiesel no Brasil é a soja, que vem se expandindo pelo país desde 1970. Sua cultura iniciou-se no sul do país e avançou para a região central, expandindo-se, gradativamente, ao norte do Brasil, principalmente por meio de latifúndios monocultores e controlados por grandes empresas transnacionais. A área de avanço agrícola ao norte tem substituído o bioma local: a Floresta Amazônica, o que tem preocupado entidades públicas e privadas, diante o desmatamento exagerado e perda da biodiversidade. O estado do Mato Grosso apresentou um alto crescimento de produção de grãos, principalmente de soja, e de desmatamento, nas últimas décadas. A região de São José do Xingu, localizada no norte do Mato Grosso, é interface entre o crescimento agrícola e a Floresta Amazônica, e foi escolhida como estudo de caso. Verificou-se que o desmatamento recente da Floresta na área de avanço agrícola está sendo promovido pela atividade pecuária, e os solos descampados e erodidos do pasto têm sido usados com a cultura de soja. Ou seja, a soja estabelece-se em áreas antes degradadas pelo gado e não diretamente sobre as áreas de floresta desmatada. Verificou-se, também, a potencialidade do norte do Mato Grosso para produção de biodiesel de soja para atender a demanda de um mercado regional, já que encontra-se tão distante do centro consumidor do país. Entretanto, São José do Xingu tem maiores entraves logísticos e tem sua produção de soja vinculada às empresas transnacionais localizadas na região, não tendo, a curto prazo, potencialidade para produção de biodiesel. 


\begin{abstract}
DOMINGUES, M.S. Assessment of soybean monoculture as raw material for biodiesel production and its relation to the deforestation of the Amazon Rainforest: A case study in Sao Jose do Xingu (MT). 2010. Master Degree Dissertation. Graduate Program in Energy, Institute for Electrotechnical and Energy, University of São Paulo.
\end{abstract}

This dissertation examines the production of soy biodiesel in the country and its relation to the deforestation of the Amazon rainforest. With reference to the National Program for Production and Use of Biodiesel - PNPB (Programa Nacional de Produção e Uso de Biodiesel), created in 2004 with the aim of promoting the integration of biodiesel into diesel fuel, reducing dependence on foreign imported oil and adding value to the field productions, it is noted that the main raw material for biodiesel production in Brazil is soy, which has been expanded across the country since the 1970s. Its culture began in the south and advanced into the central region, spreading gradually to the north of Brazil, mainly through monoculture land properties controlled by large transnational corporations. The area of agricultural expansion to the north has replaced the local biome: the Amazon rainforest; such fact has worried both the public and private, since there are excessive deforestation and biodiversity loss. In recent decades, the state of Mato Grosso showed on the one hand a high growth of grain production, especially soybeans, and on the other hand deforestation. The region of Sao Jose do Xingu, located in northern Mato Grosso, represents an interface between agricultural growth and rainforest, and as such was chosen as a case study. It has been noticed that the recent deforestation of forest in the area of agricultural expansion is being promoted by the livestock industry, and soil eroded from the open fields and pastures have been recovered with the soybean crop. That is, soy is established in areas previously degraded by livestock, and not directly on the areas of cleared forest. Furthermore, it has been verified the potential of northern Mato Grosso to produce biodiesel from soybeans to meet the demands of a regional market, since it is so far from the consumer center of the country. However, Sao Jose do Xingu has greater logistical barriers and has its soybean production linked to transnational companies located in the region. Therefore, such region does not have, in the short term, potential for biodiesel production. 


\section{LISTA DE FIGURAS}

Figuras

Descrição

Página

$\begin{array}{lll}\text { Figura 2.1 } & \text { Estrutura do PNPB. } & 35\end{array}$

Figura 2.2 Usinas de Biodiesel vencedoras de leilões 46

$\begin{array}{lll}\text { Figura 3.1 Produção de soja no Brasil } & 53\end{array}$

$\begin{array}{lll}\text { Figura 3.2 Soja ao lado da Floresta Amazônica } & 59\end{array}$

$\begin{array}{lll}\text { Figura 3.3 } & \begin{array}{l}\text { Trator encoberto pela poeira preparando o plantio com floresta } \\ \text { remanescente ao fundo em Canarana (MT) }\end{array}\end{array}$

Figura 4.1 Arco de deflorestamento da Amazônia 82

$\begin{array}{lll}\text { Figura 4.2 Queimadas em área de floresta } & 85\end{array}$

$\begin{array}{lll}\text { Figura 4.3 Evolução da área plantada de soja } & 91\end{array}$

Figura 5.1 Vista aérea de São José do Xingu 92

Figura 5.2 Município de São José do Xingu 94

Figura 5.3 Interface entre área de preparo de solo para plantio de soja e 98

Figura 5.4 Área de APP em reconstituição de mata nas cabeceiras dos rios. $\quad 100$

Figura 5.5 Cultura de soja em abril de 2007, na Fazenda bang-bang 101

$\begin{array}{lll}\text { Figura 5.6 Área de Visita ao campo } & 103\end{array}$

$\begin{array}{lll}\text { Figura 5.7 Rua Principal do município de Feliz Natal } & 109\end{array}$

Figura 5.8 Perfil Panorâmico da Usina Cooperfeliz - Feliz Natal (MT) 110

Figura 5.9 Descaroçador de sementes e armazéns na Usina Cooperfeliz - 110

Figura 5.10 Tanques de armazenamento da Usina CLV - Colíder (MT) 116

$\begin{array}{lll}\text { Figura 5.11 } & \text { Tanques de glicerina da Usina CLV - Colíder (MT) } & 117\end{array}$

$\begin{array}{lll}\text { Figura 5.12 } & \text { Projeto de plantação de pinhão manso promovido pela usina CLV } & 118 \\ & \text { e SEMA para fertirrigação. }\end{array}$

Figura 5.13 Fachada da Prefeitura Municipal de São José do Xingu 119

$\begin{array}{lll}\text { Figura 5.14 Preparo de solo para plantio com uso do arado } & 120\end{array}$ 
$\begin{array}{lll}\text { Figura 5.15 APP não degradada com mata nativa na fazenda Bang-bang } & 124\end{array}$

Figura 5.16 Degradação de APP na cabeceira do rio na fazenda bang-bang 124

Figura 5.17 Placa da Fazenda Bang-bang em referência ao Projeto Y Ikatu 125

$\begin{array}{lll}\text { Figura 5.18 Secador de grãos na fazenda Limoeiro } & 127\end{array}$

$\begin{array}{lll}\text { Figura 5.19 Preparo de solo com uso do calcário na fazenda Limoeiro } & 127\end{array}$

$\begin{array}{lll}\text { Figura 5.20 Área de plantio na Fazenda Santa Maria } & 128\end{array}$

Figura 5.21 Preparo de solo com uso do correntão na fazenda Santa Maria $\quad 129$

Figura 5.22 Preparo de solo com palha de milhete na fazenda Santa Maria $\quad 129$

$\begin{array}{lll}\text { Figura 5.23 Preparo de solo limitando com a reserva } & 130\end{array}$

$\begin{array}{lll}\text { Figura 5.24 Localização da área de estudo } & 131\end{array}$

$\begin{array}{lll}\text { Figura 5.26 Imagem de Satélite de } 1984 & 132\end{array}$

$\begin{array}{lll}\text { Figura 5.27 } & \text { Imagem de Satélite de } 1994\end{array}$

$\begin{array}{lll}\text { Figura 5.28 Imagem de Satélite de } 2009 & 138\end{array}$ 


\section{LISTA DE QUADROS}

Quadros

Descrição

Página

Quadro 2.1 Relação de leis, decretos, portarias e instruções normativas que

Quadro 2.2 Programa de apoio Financeiro a investimentos do biodisel

Quadro 2.3 Características tributárias do PNPB

Quadro 2.4 Resultado dos leilões da ANP

\section{LISTA DE GRÁFICOS}

\section{Gráficos}

Descrição

Página

Gráfico 2.1 Efeito do Biodiesel sobre as emissões associadas ao diesel 30

Gráfico 3.1 Distribuição da produção de soja por estado. Safra 200/2007

Gráfico 3.2 Evolução da produtividade da soja em regiões do Brasil em anos 57

Gráfico 3.3 Matérias-primas utilizadas para produção de biodiesel 70

Gráfico 3.4 Participação dos produtores de biodiesel de soja e a renda em cada atividade

Gráfico 4.1 Evolução da produção de soja no estado do Mato-Grosso $1976-2005$.

\section{LISTA DE MAPAS}

Mapa Descrição

Página

Mapa 1 Localização da Área de Estudo

Mapa 2 Uso do solo de São José do Xingu - 1984.

Mapa 3 Uso do solo de São José do Xingu - 1994.

Mapa 4 Uso do solo de São José do Xingu - 2009. 


\section{LISTA DE TABELAS}

Tabelas

Descrição

Página

Tabela 2.1 Produção de Combustíveis e Dependência Externa 29

$\begin{array}{lll}\text { Tabela 2.2 } & \begin{array}{l}\text { Participação mínima de agricultura familiar entre os fornecedores } \\ \text { de matéria-prima para obtenção do Selo Combustível Social. }\end{array} & 47\end{array}$

$\begin{array}{lll}\text { Tabela 3.1 } & \text { Evolução da produção, área plantada e produtividade da soja no } \\ \text { Brasil 1990-2006. } & 52\end{array}$

$\begin{array}{lll}\text { Tabela 3.2 Potencial para expansão agrícola } & 58\end{array}$

$\begin{array}{lll}\text { Tabela 3.3 } & \begin{array}{l}\text { Características de alguns vegetais com potencial para produção de } \\ \text { biodiesel }\end{array}\end{array}$

$\begin{array}{lll}\text { Tabela 4.1 Distribuição de Projetos aprovados pela Sudam } & 78\end{array}$

$\begin{array}{lll}\text { Tabela 4.2 } & \begin{array}{l}\text { Estimativas anuais desde } 1988 \text { até } 2006 \mathrm{em} \text { anos selecionados. } \\ \text { Taxa de desmatamento anual }\left(\mathrm{km}^{2} / \mathrm{ano}\right) .\end{array}\end{array}$

Tabela 5.1 Principais Atividades Econômicas de São José do Xingu (MT) 99 
LISTA DE ABREVIATURAS E SIGLAS

\begin{tabular}{|c|c|}
\hline ABIODIESEL & Associação Brasileira de Biodiesel \\
\hline $\mathbf{A C}$ & Acre \\
\hline ADA & Agência de desenvolvimento da Amazônia \\
\hline $\mathbf{A M}$ & Amazonas \\
\hline ANP & Agência Nacional de Petróleo. \\
\hline ANPA & Associação Nacional dos Pequenos Agricultores \\
\hline $\mathbf{A P}$ & Amapá \\
\hline $\mathbf{A P P}$ & Área de Preservação Permanente \\
\hline ATER & Assistência Técnica e Extensão Rural \\
\hline B2 & 2\% de Biodiesel adicionado ao Diesel comum \\
\hline B5 & $5 \%$ de Biodiesel adicionado ao Diesel comum \\
\hline B10 & $10 \%$ de Biodiesel adicionado ao Diesel comum \\
\hline B20 & $20 \%$ de Biodiesel adicionado ao Diesel comum \\
\hline B50 & $50 \%$ de Biodiesel adicionado ao Diesel comum \\
\hline B100 & 100\% de Óleo vegetal (Biodiesel) \\
\hline BEC & Batalhão de Engenharia de Construção \\
\hline BID & Banco Intramericano de Desenvolvimento \\
\hline BIRD & Banco Internacional de Reconstrução e Desenvolvimento \\
\hline BNDES & Banco Nacional de Desenvolvimento Econômico e Social. \\
\hline C\&T & Ciência e Tecnologia. \\
\hline CEFET & Centro Federal de Educação Tecnológica \\
\hline CEIB & Comissão Executiva Interministerial. \\
\hline CENBIO & Centro Nacional de Referência em Biomassa. \\
\hline CENPES & Centro de Pesquisas da Petrobras \\
\hline CEPEA/USP & $\begin{array}{l}\text { Centro de Estudos Avançados em Economia Aplicada da Universidade de São } \\
\text { Paulo }\end{array}$ \\
\hline CEPLAC & Comissão Executiva de Plano de Lavoura \\
\hline CERBIO & Centro Brasileiro de Referência em Biocombustíveis \\
\hline $\mathrm{CH}_{4}$ & Metano. \\
\hline CIDE & Contribuição de intenção no Domínio Econômico. \\
\hline CNPE & Conselho Nacional de Política Energética. \\
\hline $\mathrm{CO}_{2}$ & Dióxido de Carbono. \\
\hline CONAB & Companhia Nacional de Abastecimento \\
\hline CONTAG & Confederação Nacional dos Trabalhadores na Agricultura. \\
\hline DESER & Desenvolvimento de Estudos Sócio-Econômicos Rurais. \\
\hline EMATER & Empresa de Assistência Técnica e Rural. \\
\hline EMBRAPA & Empresa Brasileira de Pesquisa Agropecuária. \\
\hline $\begin{array}{l}\text { EMPAER } \\
\text { et al }\end{array}$ & $\begin{array}{l}\text { Empresa Mato-grossense de Pesquisa, Assistência e Extensão Rural S/A } \\
\text { e colaboradores. }\end{array}$ \\
\hline FАMАTO & Federação da Agricultura e Pecuária do Estado do Mato-grosso \\
\hline FBOMS & Fórum Brasileiro de Ongs e Movimentos Sociais para o meio ambiente \\
\hline FEA -RP & Faculdade de Economia, Administração e Contabilidade de Ribeirão Preto. \\
\hline FETRAF & Federação dos Trabalhadores da Agricultura Familiar. \\
\hline FGV & Faculdade Getúlio Vargas \\
\hline FUNAI & Fundação Nacional do Índio \\
\hline
\end{tabular}




\begin{tabular}{|c|c|}
\hline FUNASA & Fundação nacional de Saúde \\
\hline GEE & Gases de Efeito Estufa. \\
\hline GNV & Gás Natural Veicular. \\
\hline GO & Goiás \\
\hline ha & Hectare \\
\hline IAC & Instituto Agronômico de Campinas \\
\hline IBAMA & Instituto Brasileiro do Meio Ambiente e dos Recursos Naturais Renováveis. \\
\hline IBGE & Instituto Brasileiro de Geografia e Estatística. \\
\hline IEA & Instituto de Economia Agrícola. \\
\hline IPEA & Instituto de Pesquisa econômica e Aplicada. \\
\hline INDEA & Instituto de Defesa Agropecuária \\
\hline INT & Instituto Nacional de Tecnologia. \\
\hline IPI & Imposto Sobre Produtos Industrializados. \\
\hline IPT & Instituto de Pesquisas Tecnológicas. \\
\hline ISA & Instituto Sócio Ambiental \\
\hline kg & Quilograma \\
\hline LAU & Licença Ambiental Única \\
\hline MA & Maranhão \\
\hline MAPA & Ministério de Agricultura, Pecuária e Abastecimento \\
\hline MCT & Ministério da Ciência e Tecnologia \\
\hline MDA & Ministério do Desenvolvimento Agrário. \\
\hline MMA & Ministério do Meio Ambiente \\
\hline MME & Ministério de Minas e Energia. \\
\hline MT & Mato Grosso \\
\hline NAE & Núcleo de Assuntos Estratégicos \\
\hline ONG & Organização Não-Governamental \\
\hline OVEG & Programa Nacional de Energia de Óleos Vegetais. \\
\hline PA & Pará \\
\hline PA & Projeto de Assentamento \\
\hline PCH & Pequena Central Hidrelétrica \\
\hline PETROBRAS & Petróleo Brasileiro SA. \\
\hline PIX & Parque Indígena do Xingu \\
\hline PNPB & Programa Nacional de Produção e Uso do Biodiesel. \\
\hline PROALCOOL & Programa Nacional do Álcool. \\
\hline PROINFA & Programa de Incentivo às Fontes Alternativas de Energia Elétrica. \\
\hline PRONAF & Programa Nacional de Fortalecimento da Agricultura Familiar. \\
\hline PRO-ÓLEO & Programa Nacional de Produção de Óleos Vegetais para Fins Energéticos. \\
\hline PROPASTO & Programa de Recuperação de Pasto Degradado \\
\hline PROSOLO & Programa de Incentivo ao Uso de Corretivo de Solo \\
\hline RADAM & Radares para Amazônia \\
\hline RO & Rondônia \\
\hline $\mathbf{R} \mathbf{R}$ & Roraima \\
\hline S.A. & Sociedade Anônima \\
\hline SENAR & Serviço Nacional de Aprendizagem Rural do Mato Grosso \\
\hline SIN & Sistema Interligado Nacional \\
\hline SINDIPEÇAS & Sindicato Nacional da Indústria de Componentes para Veículos Automotores \\
\hline SIVAM & Sistema de Vigilância da Amazônia \\
\hline SP & São Paulo \\
\hline
\end{tabular}


SPI

SPVEA

SRF

SUDAM

SUFRAMA

SUS

TAC

TCT

TECBIO

TJLP

ton.

UNICAMP

UNITINS

USP

UTM
Serviço de Proteção ao Índio

Superintendência de Valorização Econômica da Amazônia

Secretaria da Receita Federal

Superintendência para o Desenvolvimento da Amazônia

Superintendência da Zona Franca de Manaus.

Sistema Único de Saúde

Termo de Ajustamento de Conduta

Termo de Cooperação Técnica.

Tecnologias Bioenergéticas

Taxa de Juros a Longo Prazo.

Tonelada

Universidade de Campinas

Fundação Universidade do Tocantins

Universidade de São Paulo

Universal Transversa de Mercator. 


\section{SUMÁRIO}

\section{CAPÍTULOS}

PÁGINAS

$\begin{array}{lll}\text { 1. Introdução } & 18\end{array}$

1.1 Objetivos $\quad 22$

$\begin{array}{ll}1.2 \text { Metodologia } & 24\end{array}$

2. Programa Nacional de Biodiesel 29

$\begin{array}{ll}\text { 2.1 Marco Regulatório } & 34\end{array}$

2.2 Estrutura Econômica do PNPB 40

2.3 Estrutura Produtiva do PNPB 44

2.4 Avaliação critica ao PNPB 49

3. A Cultura de soja no Brasil e o PNPB 51

3.1. Evolução da Produção de soja

$\begin{array}{lll}3.2 & \text { Estrutura Produtiva da soja } & 60\end{array}$

3.3. Impactos da cultura sojeira $\quad 62$

$\begin{array}{ll}\text { 3.3.1. Nas águas e no solo } & 63\end{array}$

3.3.2. Na Biodiversidade e no clima 65

3.4. Participação da soja no PNPB 68

4. O Processo de Desmatamento da Amazônia 75

$\begin{array}{ll}\text { 4.1 Contextualização Econômica } & 75\end{array}$

4.2. O desmatamento na Amazônia 80

$\begin{array}{ll}\text { 4.2.1 Queimadas } & 83\end{array}$

4.3. Expansão da soja e desmatamento 86

5. Estudo de caso: a região do Município São José do Xingu (MT) 92 
5.2. Pesquisa de Campo 102

5.2.1. Ponto1 - Município de Sorriso (MT) - Usina Agrossoja 105

5.2.2. Ponto 2 - Município de Feliz Natal (MT) - Usina Cooperfeliz 109

5.2.3.Ponto 3 - Município de Sinop (MT) - Usinas desativadas(KGB)112

5.2.4. Ponto 4 - Município de Colíder (MT) - Usina CLV 115

5.2.5. Ponto 5 - Município de São José do Xingu (MT) 119

5.3. Análise dos mapas de uso do solo na região de estudo 131

6. Conclusões 143

7. Referências Bibliográficas 148

8. Anexos 1 e 2 


\section{INTRODUÇÃO}

Desde a II Revolução Industrial, ocorrida no século XIX na década de 1850, o petróleo domina o mercado mundial de combustíveis e seus derivados. A escolha desse insumo energético naquela época foi baseada na sua abundância, eficiência e preços atrativos, o que vem determinando o seu uso desde então.

Entretanto, após um século de crescente atividade energética baseada em combustíveis fósseis, a taxa de crescimento do consumo aumentou geometricamente em todo planeta. Com esse acréscimo, houve registro de altos índices de poluentes emitidos pela sua queima, principalmente por motores automotivos.

A emissão de poluentes atmosféricos também é complementada com o lançamento dos conhecidos Gases de Efeito Estufa - GEE, dentre eles o dióxido de carbono $\left(\mathrm{CO}_{2}\right)$ e o metano $\left(\mathrm{CH}_{4}\right)$. Com a provável escassez das reservas de petróleo conhecidas (que durariam cerca de 40 anos), pesquisas estão sendo realizadas para se obter a substituição ou complementação da matriz energética mundial (Holanda, 2004 \& NAE, 2005).

No Brasil, o óleo diesel é o grande responsável na movimentação do setor de transportes. O desenvolvimento econômico e industrial brasileiro foi baseado na expansão rodoviária e a maior parte da frota brasileira para circulação de produtos e mercadorias é composta de caminhões movidos a óleo diesel, sendo caracteristicamente o combustível mais consumido no Brasil.

Considerando o perfil de produção das refinarias brasileiras, uma fração crescente desse produto vem sendo importada. Nossa importação anual de óleo diesel variou aproximadamente, nos últimos oito anos, entre 14 a 40 milhões de barris, chegando, em 2007, a 32 milhões de barris, gerando uma despesa de cerca de 3 bilhões de dólares na nossa balança de pagamentos (ANP, 2008).

Atualmente, uma discussão tem fomentado a substituição do petróleo, ou ao menos, a complementação desta matriz energética a partir do biodiesel. O biodiesel é um combustível derivado de fontes renováveis, podendo ser extraído de quaisquer vegetais que tenham teor oleaginoso suficiente para tal uso. Dentre estes vegetais cita-se, o dendê, o babaçu, a soja, a mamona, o girassol, a canola, o algodão entre outras e que pode ser usado puro ou misturado ao diesel sem necessidade de nenhuma modificação nos motores de ciclo diesel dos veículos de carga e passeio ou motores estacionários para diversos fins. 
O interesse econômico e ambiental de inserir no mercado um novo combustível, seja na sua forma pura ou associada a outros combustíveis, tem sido um dos objetivos do setor energético para amenizar os impactos ambientais causados pelos consumidores de combustíveis fósseis e diminuir a dependência energética desses recursos não renováveis. Levando-se em consideração o potencial agrícola brasileiro e os condicionantes ambientais mundiais, torna-se oportuno discutir a produção de fontes alternativas de energia, “ecologicamente sustentáveis".

O biodiesel pode ser um importante produto para exportação e para a independência energética nacional. Associada à geração de emprego e renda nas regiões mais carentes do Brasil, representaria soluções de cunho regional mediante o aproveitamento econômico dos insumos disponíveis, já que o país tem todas as condições de se tornar um grande produtor de biodiesel. Tem um potencial incomparável para produção de biomassa para fins alimentares, químicos e energéticos devido a sua imensa extensão territorial e suas excelentes condições edafoclimáticas.

A produção de oleaginosas, como exemplo da mamona, do dendê e da soja, podem ser abundantes fontes de energia e uma importante fonte estratégica para o setor energético brasileiro, além do enfoque dado a essa nova matriz de que poderá ser uma ferramenta de inclusão social e econômica, haja vista o interesse do governo brasileiro em incentivar o sistema de agricultura familiar para produção desta nova fonte energética.

Diante esse cenário, foi criado o Programa Nacional de Produção e Uso do Biodiesel - PNPB - um programa interministerial do Governo Federal que objetiva a implementação sustentável, técnica e econômica da produção e uso do biodiesel, com enfoque na inclusão social e no desenvolvimento regional, via geração de emprego e renda. (Chiaranda, 2005).

Esse programa vem propor, através de suas ações, a divulgação das informações, a fim de promover de forma ágil e articulada, a comunicação entre os agentes envolvidos, assim como, fazer do programa um instrumento para o desenvolvimento das ações. Outro fator que favorece o estímulo nesse momento da produção do biodiesel é o nível de preços do petróleo, na faixa de US\$100,00 por barril em 2008.

Após diversos eventos realizados sobre a situação do biodiesel no Brasil e da tarefa governamental de implantá-lo na matriz energética brasileira, foram elaborados vários trabalhos de pesquisa com espécies oleaginosas, cujo intuito seria de viabilizá-las à 
implantação de novas fontes energéticas no país, haja vista o comprovado potencial de produção de biomassa para fins energéticos.

Uma oleaginosa possui potencialidade agrícola já consolidada e seu cultivo é muito difundido no país: a soja A soja é originalmente típica de países temperados, mas já foi "tropicalizada", sendo cultivada em diversas regiões do Brasil. (Bermann, 2007).

De acordo com Macedo (2005), atualmente no Brasil, a soja ocupa 22 milhões de hectares e existem cerca de 100 milhões de hectares aptos à expansão dessa monocultura. Essa expansão cresce nos países do Mercosul - Brasil, Argentina, Paraguai e Uruguai assim como a presença de grandes empresas multinacionais nos segmentos de comercialização e industrialização, que se estende em áreas de produção de sementes e financiamentos da produção do grão.

As indústrias de processamento de soja têm grande interesse em participar na produção do biodiesel. O setor que apresentava, em 2005, uma capacidade ociosa de 10 milhões de toneladas por ano, assedia agora o governo com uma série de argumentos para justificar uma variedade de favores do Estado: subsídios, isenções fiscais, financiamento com recursos públicos e outros, para acelerar o ingresso no Programa Nacional de Produção e Uso do Biodiesel (Schlesinger, 2006).

A expansão da área plantada tem se dado, sobretudo, sentido norte a partir da região central brasileira, ou seja, atingindo diretamente o ecossistema frágil correspondente à Floresta Amazônica. Essa expansão tem gerado impactos sócio-ambientais que envolvem desde queimadas nas áreas da Floresta Amazônica para expansão da área plantada (que respondem a grandes percentuais de gases de efeito estufa emitidos na atmosfera), a mudanças no uso da terra, concentração latifundiária entre outros.

No Estado do Mato Grosso, a área de floresta desmatada correspondeu, entre $2003 \mathrm{e}$ 2004, a um crescimento percentual de $6 \%$ em relação ao período anterior, ou seja, cerca de 26.130 quilômetros quadrados de desmatamento, sabendo-se que grande parte deste advém da expansão da soja (Schlesinger, 2006).

Em relação aos impactos sociais, observa-se o deslocamento de populações para as cidades devido a introdução da monocultura da soja por meio da mecanização, uso de fertilizantes e sementes melhoradas geneticamente, além de expansão de grandes propriedades de terra. As grandes empresas ocupam espaços no campo antes ocupado por 
culturas familiares diversificadas, reduzindo o emprego no campo, a capacidade de produção de alimentos tradicionais, comprometendo a segurança alimentar da população.

A soja é notadamente a cultura mais bem estabelecida no território brasileiro e pode representar uma das principais oleaginosas do Programa Nacional do Biodiesel. Entretanto, isso poderá colaborar para uma alteração ainda maior da paisagem geográfica do país, causando malefícios à biodiversidade e às populações do campo.

Logo, este trabalho tem por objetivo analisar o avanço da soja e sua relação com a produção de biodiesel e desmatamento, o que será especificado no subcapítulo 1.2. Objetivos, onde tratou-se de especificar quais as metas a serem cumpridas. A Metodologia deste trabalho pode ser verificada no subcapítulo 1.3, mostrando quais ferramentas serão utilizadas para esse fim.

O capítulo 2 traz as diretrizes e a implementação do Programa Nacional de Produção e Uso de Biodiesel (PNPB), com a contextualização do programa desde sua criação até o momento atual. Mostra sua estrutura regulatória, econômica e produtiva, e ainda traz uma avaliação crítica apontando alguns erros ou sugerindo melhorias para a gestão do PNPB.

O capítulo 3 disserta sobre a cultura de soja no Brasil e sua relação com o PNPB, relatando a evolução desta cultura no país, sua estrutura produtiva e seus impactos no meio ambiente: nas águas e no solo e na biodiversidade e no clima. Também, mostra qual a efetiva participação dessa matéria-prima no Programa Nacional de Biodiesel.

O capítulo 4 introduz a Amazônia, com um breve histórico de ocupação, aprofundando-se no desmatamento, nas queimadas e na expansão da soja na Floresta e na área de fronteira agrícola.

Já o capítulo 5, traz o Estudo de Caso da região de São José do Xingu (MT), com histórico e economia do município, resultados da pesquisa de campo e a análise dos três mapas de uso do solo, resultados da interpretação as imagens de satélite de 1984, 1994 e 2009.

Por fim, o capítulo 6 contém as conclusões do tema investigado; o capítulo 7, as referências bibliográficas e sítios da web consultados; e os anexos no capítulo 8. 


\subsection{Objetivos}

O presente estudo pretende fazer uma avaliação histórica mais recente da soja como matéria-prima para o biodiesel, buscando-se analisar as potencialidades agrícolas da soja por região produtiva e os efeitos ambientais que serão gerados em razão dessa cultura.

Além da criação de novas relações de trabalho no modo de produção, atributos ambientais envolvidos para produção dessa planta para fins energéticos e suas consequiências para um mercado controlado por transnacionais há o aumento no preço do óleo de soja e maior controle dessas nos produtos agrícolas e dos combustíveis.

Pretende-se verificar a expansão da soja diretamente na área de Floresta Amazônica, área de fronteira agrícola ao norte do país que tem sido desmatada para avanço da pecuária e culturas para exportação.

Os objetivos específicos dessa pesquisa são:

- Analisar a evolução da área plantada de soja de 1984 a 2009 em relação ao desmatamento da Floresta Amazônica;

- Averiguar o avanço da cultura sobre a área de fronteira agrícola;

- Verificar a expansão da soja em relação aos aumentos de preço do produto no mercado internacional.

- Avaliar os mapas de uso do solo em relação a outras áreas brasileiras produtoras de biodiesel de soja e suas perspectivas futuras.

Assim, é possível discutir meios de contribuir para a implantação de um novo modelo agrícola no Brasil, baseado na defesa dos direitos humanos, na democratização do acesso a terra e aos demais recursos naturais, além de propor uma diversificação produtiva, no fortalecimento econômico e político da produção familiar, na geração de renda para o trabalhador do campo e na melhoria de sua qualidade de vida, na agroecologia e na preservação do meio ambiente.

Trata-se de enfrentar as transnacionais que concentram de maneira crescente o controle da produção agrícola brasileira, por meio de estratégias e ações conjuntas entre políticas públicas e a organização social.

Este estudo possui relevância social ao discutir sobre o processo de beneficiamento do óleo de soja por meio de transnacionais ou por cooperativas ou pequenas propriedades, que geram maiores índices de emprego. 
Possui relevância econômica ao tratar das possíveis reduções de importações do diesel comum com a possibilidade futura de exportação de biodiesel como combustível renovável, geração de renda no campo, elevações, subsídios e commodities dos preços da soja no mercado interno e externo.

E também possui relevância ambiental ao tratar do uso de combustível renovável, melhoria na qualidade de vida com a redução de emissão de gases nocivos e expansão agrícola nas áreas de floresta por meio de desmatamento e queimadas. 


\subsection{Metodologia}

Para realização desse trabalho, pesquisou-se as bibliografias disponíveis referentes ao assunto, obteve-se informações com especialistas e entidades especializadas sobre o cultivo de soja, analisando sócio-economicamente a viabilidade da produção do biodiesel em grande escala no país.

Também foram realizadas coleta e sistematização de dados, além da interpretação de imagens de satélite disponíveis das áreas de avanço da fronteira agrícola para elaboração de mapas de uso de solo.

Analisou-se estrategicamente a expansão da soja para as áreas de fronteira agrícola no período de 25 anos, de 1984-2009, e seus efeitos sócio-ambientais, por meio de imagens de satélite, a fim de elaborar uma série histórica com três datas diferentes, resultando em três mapas de uso do solo da área estudada onde foi possível analisar as potencialidades da região e as mudanças verificadas ao longo do tempo.

A metodologia adotada para a interpretação das imagens e realização dos objetivos as consagradas técnicas científicas e o uso de tecnologia de última geração, utilizando como ferramenta técnicas de sensoriamento remoto ${ }^{1}$ e SIG (Sistema de Informação Geográfica).

O sensores remoto que utilizamos neste trabalho estão instalados no Satélite Landsat 5 , satélite multiespectral que possui frequiência variada entre infra-vermelho, fornecendo dados em sete bandas diferentes. O contraste dessas bandas permite diferenciar os diferentes usos de solo.

As imagens orbitais trabalhadas passaram pelas etapas do processamento digital ${ }^{2}$, permitindo sua posterior interpretação ${ }^{3}$. Nesse trabalho, o termo uso do solo é aplicado ao espaço ocupado, quer por aspectos naturais ou por atividades desenvolvidas pelo homem, referindo-se ao uso atual da terra, ou seja, para descrição das características da paisagem em determinada época.

\footnotetext{
${ }^{1} \mathrm{O}$ sensoriamento remoto revela-se como a tecnologia que permite obter imagens e outros tipos de dados, da superfície terrestre, através da captação e do registro da energia refletida ou emitida pela superfície. O termo sensoriamento refere-se à obtenção dos dados, e remoto que significa distante é utilizado, pois a obtenção é feita à distância, ou seja, sem o contato físico entre o sensor e a superfície terrestre (Novo, 1988).

${ }_{2}$ Processamento digital define-se por um conjunto de técnicas e operações sobre uma imagem digital qualquer, com o objetivo de facilitar a extração e identificação de informações.

${ }^{3}$ A interpretação de imagens é o ato de analisar as imagens com o propósito de identificar objetos ou alvos e deduzir seu significado.
} 
Para isso é necessária a elaboração de uma chave de interpretação, que consiste na descrição de um conjunto de elementos de fotointerpretação que caracterizam um determinado alvo da superfície terrestre de forma mais precisa e objetiva. Neste caso, pretende-se utilizar chaves de interpretação voltadas para o mapeamento do uso do solo. (Pereira et al., 1998).

O objetivo final de classificação da imagem gera um mapa temático demonstrando a configuração espacial da nossa área de estudo, ou seja, um mapa de uso do solo o qual é objeto desse estudo. Pretende-se elaborar esse três mapas a partir da interpretação das imagens de satélite. (Novo, 1988).

Para tal, seguiu-se por tais procedimentos:

- Escolha da área de estudo: A área de estudo escolhida se deu por meio da sobreposição de dados: Existência de usinas de biodiesel $\mathrm{X}$ áreas de desmatamento recente $\mathrm{X}$ áreas produtoras de soja, com o objetivo de contemplar que a área de expansão da fronteira agrícola está ocorrendo pelo plantio de soja, e que esse cultivo pode estar ou poderá representar parcela para produção de biodiesel no país.

Assim sendo, a área escolhida para interpretação foi a região de São José do Xingu, município localizado ao nordeste do Mato Grosso, com cultura recente de soja e inserida no Bioma Amazônico.

Além da sobreposição de dados, as imagens de satélite escolhidas datam de 1984, 1994 e 2009, sendo possível a análise em um intervalo de tempo, obtendo-se uma série histórica de 25 anos. Referem-se a imagens do satélite LANDSAT 5, à órbita 225 e ponto 67.

A última imagem de satélite selecionada datava de julho de 2008. Porém, essa não apresentava o contraste ideal para diferenciação das áreas de cultura de soja e pastagem. Então, para melhor interpretação foi selecionada uma imagem de maio de 2009, onde há diferenciação clara de áreas de pastagem e cultura.

O Mapa 1 apresenta a localização da Área de Estudo e das imagens de satélite analisadas. 


\section{Mapa 1 - Localização da área de Estudo}
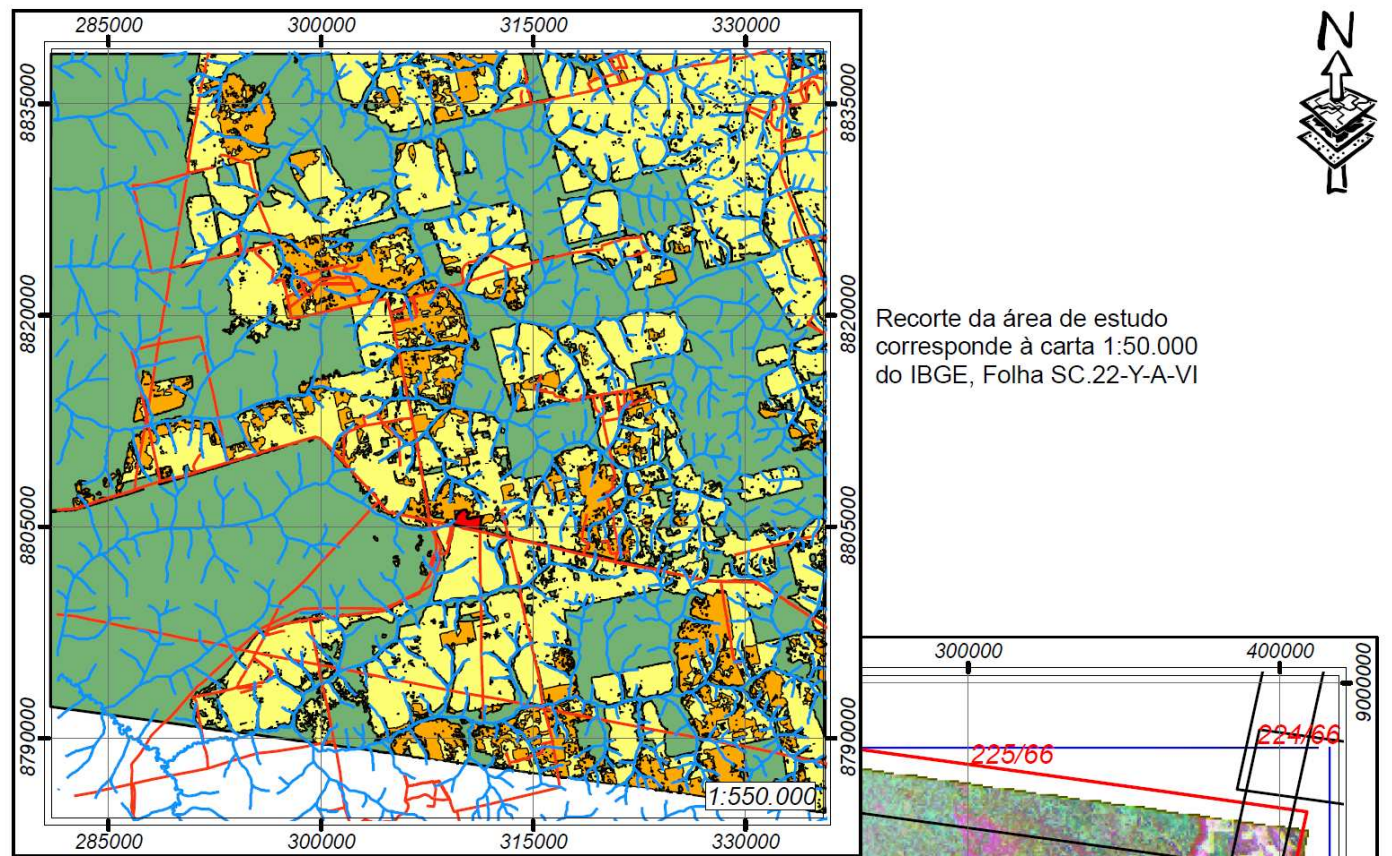

Recorte da área de estudo

corresponde à carta 1:50.000

do IBGE, Folha SC.22-Y-A-VI

Referência da Cena 225/67 do satélite Landsat - 5 TM com aplicação de constrastes, utilizada na interpretação das fisionomias estudadas no recorte a área de estudo, sobreposta na figura;
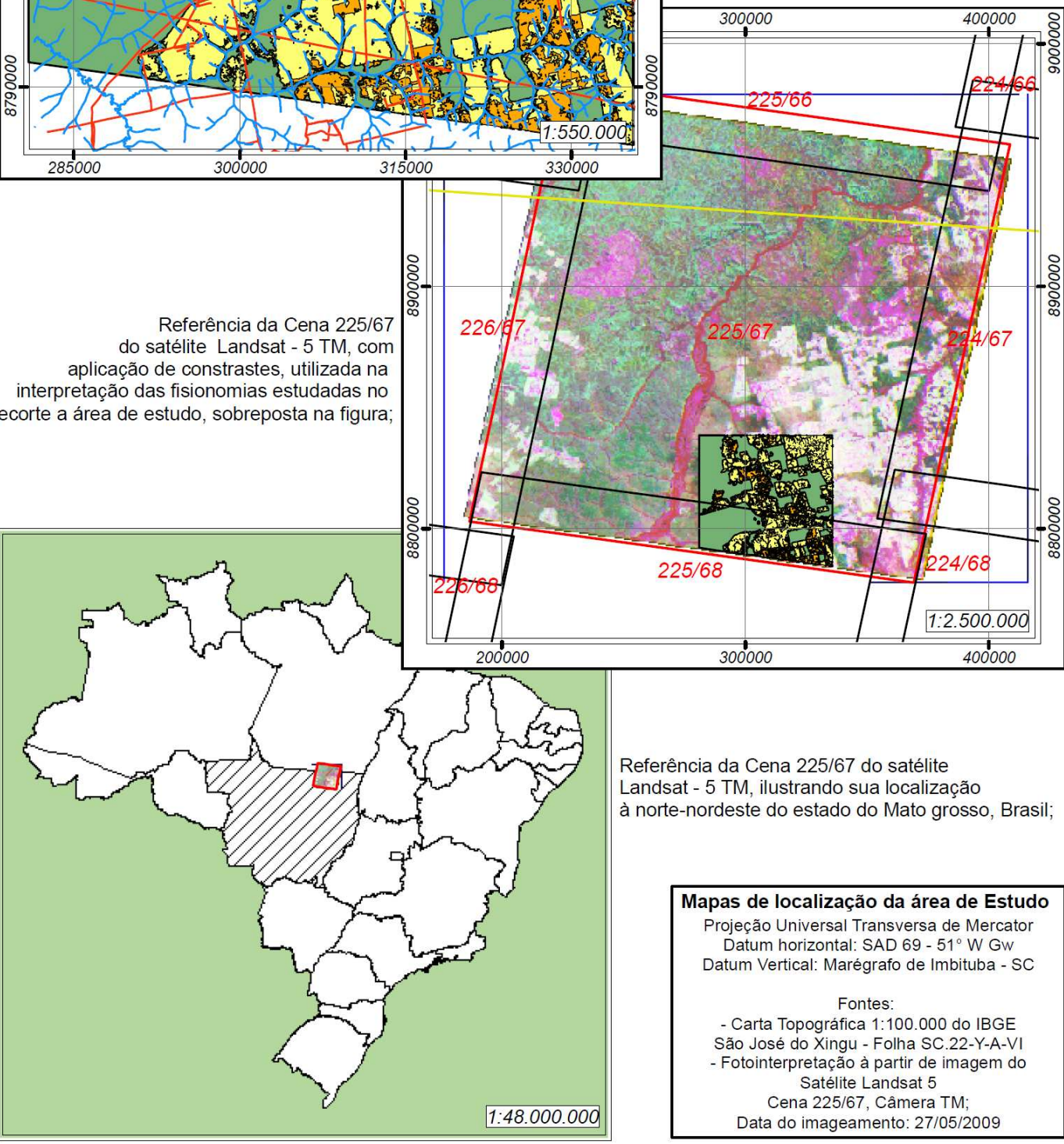

Referência da Cena 225/67 do satélite

Landsat - $5 \mathrm{TM}$, ilustrando sua localização

à norte-nordeste do estado do Mato grosso, Brasil;

Mapas de localização da área de Estudo

Projeção Universal Transversa de Mercator

Datum horizontal: SAD $69-51^{\circ} \mathrm{W}$ GW

Datum Vertical: Marégrafo de Imbituba - SC

$$
\text { Fontes: }
$$

- Carta Topográfica 1:100.000 do IBGE São José do Xingu - Folha SC 22-Y-A-VI

- Fotointerpretação à partir de imagem do Satélite Landsat 5

Satélite Landsat 5
Cena $225 / 67$, Câmera TM

Data do imageamento: 27/05/2009 
- Levantamento cartográfico: Um levantamento cartográfico confiável, conhecido e consagrado é ponto fundamental de partida para a criação de qualquer sistema digital de levantamento geo-ambiental. A base cartográfica digital para este estudo foi preparada a partir da digitalização da carta topográfica disponível de São José do Xingu, do IBGE, com escala 1:100.000, datada de 1986, e seu posterior georreferenciamento.

O georreferenciamento da carta topográfica foi feito através da grade de coordenadas, adotando-se o padrão de projeção UTM (Universal Transversa de Mercator). Esta carta compõe o "plano de fundo" sobre o qual foram vetorizadas as curvas de nível, sistemas viários, drenagem e demais informações pertinentes, ou seja, o enquadramento entre a carta topográfica e as imagens.

- Interpretação das imagens: Utilizou-se a composição das bandas 5,4,3 (RGBRed Green Blue) para interpretação das imagens. Tal composição foi a mais adequada para obter o contraste procurado: os diferentes usos das terras, visando diferenciar a cultura de soja num contexto com variadas culturas agrícolas e, principalmente, com a pecuária, definindo quatro grandes grupos de classificação: mata nativa, cultura de soja, pecuária e áreas urbanas. A classificação dos mapas de foi feita manualmente.

A partir da definição de classes da imagem, foi feita a vetorização baseada nos limites previamente definidos na interpretação, o que permitiu a quantificação das áreas estudadas. Dentro do recorte estabelecido para área de estudo quantificou-se a área total de cada classe em metros quadrados e hectares, cujo dados foram trabalhados no Excel para obtenção gráficos comparativos: dados relativos (porcentagem) e absolutos (metros e hectares) de cada classe de uso do solo.

- Análise dos mapas de uso do solo: Com os mapas prontos foi possível fazer uma análise dos dados apresentados e realizar trabalho de campo na região, obtendo novas informações e verificando as já diagnosticadas, avaliando a expansão da soja na Floresta Amazônica na região de São José do Xingu - MT. O capítulo 5 trará os mapas de uso do solo da região e sua interpretação.

- Pesquisa de campo: Essa pesquisa foi realizada entre os dias 20 e 29 de setembro de 2009, na região norte do Mato Grosso. Teve por intuito verifica in 
loco as informações obtidas na interpretação das imagens de satélite e analisar a região como área produtora de soja para biodiesel e o desmatamento associado a essa cultura.

O levantamento de campo teve como objetivo avaliar as conseqüências ambientais e sociais na área de estudo identificada a partir da superposição dos seguintes dados: existência de usinas de biodiesel $\mathrm{x}$ áreas de desmatamento recente (a partir de imagens do satélite Landsat) $\mathrm{x}$ áreas produtoras de soja.

A pesquisa de campo iniciou-se no município de Sorriso, passando por Feliz Natal, Sinop e Colíder até São José do Xingu. No período mencionado da realização desta pesquisa de campo, foram visitadas usinas de biodiesel e plantios de soja da região, assim como foram obtidas informações históricas e recentes com entidades públicas e privadas. $\mathrm{O}$ que orientou os caminhos realizados no campo foi a localização das usinas de biodiesel, até a chegada no destino final: o município de São José do Xingu, área da interpretação das imagens de satélites. 


\section{O PROGRAMA NACIONAL DE BIODIESEL}

Durante quase meio século, o Brasil desenvolveu pesquisas sobre biodiesel, promoveu iniciativas para usos em testes e foi um dos pioneiros ao registrar a patente sobre o processo de produção de combustível, em 1980.

Todos essas pesquisas foram motivadas pela dependência externa que o país possui em relação ao diesel, importando parte desse insumo. A tabela 2.1 representa os percentuais de dependência e auto-suficiência em relação às importações e exportações de gasolina, diesel, álcool e gás natural segundo dados da Petrobrás.

Tabela 2.1- Produção de Combustíveis e Dependência Externa - 2005

\begin{tabular}{|c|c|c|c|c|c|}
\hline \multirow{2}{*}{ Combustível } & Produção & $\begin{array}{c}\text { Importação } \\
\text { Líquida }\end{array}$ & $\begin{array}{c}\text { Exportação } \\
\text { Líquida }\end{array}$ & $\begin{array}{c}\text { Importação } \\
\text { Líquida }\end{array}$ & $\begin{array}{c}\text { Exportação } \\
\text { Líquida }\end{array}$ \\
\cline { 2 - 6 } & Mil m ${ }^{3}$ & Mil m & Mil m & $\begin{array}{c}\% \mathrm{da} \\
\text { demanda }\end{array}$ & $\begin{array}{c}\% \mathrm{da} \\
\text { produção }\end{array}$ \\
\hline Gasolina A & 19.978 & -- & 2.760 & -- & $14 \%$ \\
\hline Diesel & $\mathbf{3 9 . 3 9 6}$ & $\mathbf{2 . 0 7 0}$ & -- & $\mathbf{5 \%}$ & -- \\
\hline Álcool & 16.030 & -- & 2.592 & -- & $16 \%$ \\
\hline $\begin{array}{c}\text { Gás natural } \\
\left.\text { (milhões de } \mathrm{m}^{3} / \mathrm{d}\right)\end{array}$ & 48,5 & 24.4 & -- & $33 \%$ & -- \\
\hline GLP & 8.519 & 1795 & 23 & $17 \%$ & -- \\
\hline
\end{tabular}

Fonte: Elaboração própria a partir dos dados estatísticos da ANP (2008).

A tabela 2.1 mostra que, em relação ao diesel, há produção interna de $39.396 \mathrm{mil} \mathrm{m}^{3}$. Porém há ainda dependência externa com importação líquida de $2.070 \mathrm{mil} \mathrm{m}^{3}$, o que representa 5\% da demanda, de acordo com os dados de 2008 da ANP.

Outra justificativa que incentiva o desenvolvimento de pesquisas no âmbito do biodiesel é a ambiental. De acordo com Meirelles (2005), comparado ao óleo diesel derivado do petróleo, o biodiesel pode reduzir em $78 \%$ as emissões líquidas de gás carbônico, considerando-se a reabsorção pelas plantas. Além disso, reduz em $90 \%$ as emissões de fumaça e praticamente elimina as emissões de óxido de enxofre. 
Logo, o biodiesel agride menos o meio ambiente, podendo consolidar-se como combustível alternativo para o atendimento da demanda energética. No Gráfico 2.1, observa-se o efeito do biodiesel sobre as emissões atmosféricas em relação ao diesel.

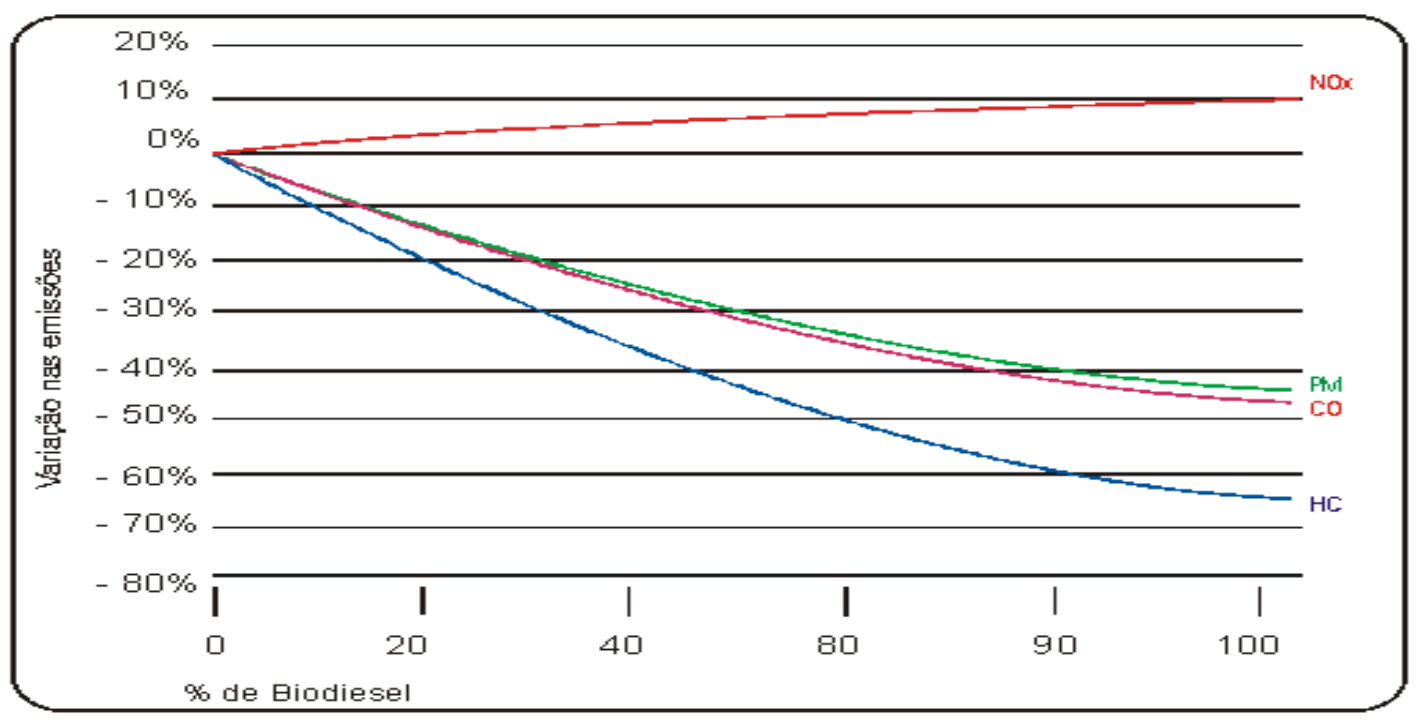

Fonte: Meirelles, 2005

Gráfico 2.1 - Efeito do biodiesel sobre as emissões associadas ao diesel

Assim, desde a década de 70, por intermédio do Instituto Nacional de Tecnologia (INT), do Instituto de Pesquisas Tecnológicas (IPT) e da Comissão Executiva do Plano da Lavoura Cacaueira (CEPLAC), o Brasil vem desenvolvendo projetos de óleos vegetais como combustíveis, destacando-se entre eles o Dendiesel.

Com a crise do petróleo na década de 70, o Brasil implantou o Programa Nacional do Álcool - Pró-álcool - para abastecer com etanol, de forma extensiva, a nova frota de veículos, em substituição a frota existente movida a gasolina, conforme plano de governo da época.

Como tendência natural, muitos veículos normalmente movidos à gasolina foram revertidos para consumir o produto disponível no mercado (álcool), justamente devido à escassez e os altos preços da gasolina. Atualmente, a tendência são os carros movidos a bicombustível, ou seja, a álcool ou gasolina, ou movidos com gás GNV - Gás Natural Veicular.

Contudo, nesse período, mesmo entre erros e acertos, o Pró-álcool apresentou um saldo positivo, pois as metas, apesar de muito ambiciosas, foram atingidas e superadas, 
demonstrando, sobretudo, a potencialidade brasileira na produção de biomassa para geração de energia (Bermann, 2007).

Todavia, cabe ressaltar a necessidade da demanda por grandes extensões de terra para produção deste combustível. Na época foram devastadas grandes extensões para atendimento dessa demanda energética, tendo como resultado a destruição de importantes e significativos nichos ecológicos e a mata atlântica (Bermann, 2007).

Em 1980, o Governo Federal criou o Programa Nacional de Produção de Óleos Vegetais para Fins Energéticos (Pró-óleo). O objetivo desse programa era gerar e introduzir o uso de óleos de origem vegetal como substituto do diesel de petróleo a preços competitivos. Esse programa não teve sucesso, em razão da falta de tecnologia adequada na época (Agência CT, 2008).

Em 1983, o Governo brasileiro motivado pela elevação desproporcional dos preços de petróleo determinou a implementação do Projeto OVEG - Programa Nacional de Energia de Óleos Vegetais - no qual foi testada a utilização de biodiesel e misturas combustíveis em veículos que percorreram mais de um milhão de quilômetros. Esta iniciativa coordenada, pela Secretaria de Tecnologia Industrial, contou com a participação da indústria automobilística, fabricantes de autopeças, produtores de lubrificantes e combustíveis, indústria de óleos vegetais e institutos de pesquisa (Agência CT, 2008).

Os resultados constataram a viabilidade técnica da utilização do biocombustível, aproveitando a logística de distribuição existente. Entretanto, naquele momento, os custos do biodiesel eram muito mais elevados do que o diesel, desta forma não foi implementado sua produção em escala comercial.

Em julho de 2001, o Ministério de Ciência e Tecnologia (MCT) instituiu o Programa de Produção de Biomassa Energética em Assentamentos do Incra na Amazônia (Probioamazon) em micro e pequenas propriedades rurais. Compreende ações de pesquisa e desenvolvimento tecnológico que viabilizem o desenvolvimento sócio-econômico de assentamentos rurais pela produção de eletricidade e combustíveis (Eco21, 2003).

Em abril de 2002, foi criado o PROINFA - Programa de Incentivo às Fontes Alternativas de Energia Elétrica. Representou uma iniciativa relevante na definição de uma política estrutural para as energias alternativas renováveis e sua implantação é marco definitivo para a ampliação de novas fontes como o biodiesel na matriz energética brasileira. 
O Programa, coordenado pelo Ministério de Minas e Energia (MME), estabelece a contratação de $3.300 \mathrm{MW}$ de energia no Sistema Interligado Nacional (SIN), produzidos por fontes eólica, biomassa e pequenas centrais hidrelétricas (PCHs), sendo 1.100 MW de cada fonte.

Em outubro de 2002, foi elaborado o Programa Brasileiro de Biocombustíveis Pró-biodiesel - coordenado pelo Ministério da Ciência e Tecnologia/ Secretaria de Política Tecnológica Empresarial tem como principal agente executor o Centro Brasileiro de Referência em Biocombustíveis - CERBIO. O Pró-biodiesel compreende ações de viabilização das tecnologias de adição do etanol e de óleos vegetais ao óleo diesel derivado de petróleo.

Diante esse cenário de ascensão de biocombustíveis, foi criado em dezembro de 2004 o Programa Nacional de Produção e Uso do Biodiesel - PNPB - um programa interministerial do Governo Federal que objetiva a implementação sustentável, técnica e econômica da produção e uso do biodiesel, com enfoque na inclusão social e no desenvolvimento regional, via geração de emprego e renda (Chiaranda, 2005).

O Programa Nacional de Produção e Uso de Biodiesel (PNPB) é um programa interministerial do Governo Federal que objetiva a implementação de forma sustentável, tanto técnica como economicamente, a produção e uso do biodiesel, com enfoque na inclusão social e no desenvolvimento regional, via geração de emprego e renda (Portal do Biodiesel, 2006).

O PNPB surgiu baseado no Pró-biodiesel, de outubro de 2002. O Pró-biodiesel foi coordenado pelo Ministério da Ciência e Tecnologia/Secretaria de Política Tecnológica Empresarial e tinha como principal agente executor o Centro de Referência em Biocombustíveis - CERBIO. O Programa compreende ações de viabilização das tecnologias para adição de biodiesel ao diesel de refinaria.

O Pró-biodiesel partia da ação integrada, em rede de pesquisas, para o desenvolvimento das tecnologias de produção e uso de misturas biocombustíveis, visando a avaliação da sua viabilidade e competitividade técnica, socioambiental e econômica para o mercado brasileiro e para exportação futura, além de sua produção e distribuição espacial nas diferentes regiões do país.

Compreendia ações de pesquisa e desenvolvimento tecnológico, incluindo testes em campo, nas adições óleos vegetais/ óleo diesel em proporções variadas, além de tecnologias 
específicas que viabilizassem o desenvolvimento sócio-econômico de assentamentos rurais pela produção de eletricidade e combustíveis (Eco 21, 2003).

O Programa Brasileiro de Biocombustíveis foi o resultado da interação e parceria para o desenvolvimento oriundos da Rede Nacional de Biocombustíveis, que congrega mais de 200 especialistas, representantes de entidades de pesquisa, associações empresariais, agências reguladoras e de fomento, Governos Federal, Estadual e Municipal e da Comissão de Minas e Energia da Câmara dos Deputados.

Nesse programa destacavam-se as entidades com responsabilidades diretas de coordenação das atividades do Programa, entre eles institutos privados, públicos e universidades associadas, tais como: IPT, CENPES, UNICAMP, USP, SINDIPEÇAS BOSCH, UNICA, ANP, PETROBRAS, IBAMA, FGV (Eco 21, 2003).

Um dos grandes desafios do Pró-biodiesel era o de constituir um projeto ecológico brasileiro; tratou-se de um esforço coordenado de remodelação das cidades, das tecnologias, das indústrias e das estruturas físicas a fim de torná-las ecologicamente sustentáveis; ou seja, capaz de atender às necessidades e satisfazer às aspirações da população sem diminuir as oportunidades das gerações futuras. (Eco21, 2003).

Assim, o Governo Federal de 2003 a 2006, criou do Programa Nacional de Produção e Uso do Biodiesel (PNPB), e, por meio deste, organizou a cadeia produtiva, definiu as linhas de financiamento, estruturou a base tecnológica e editou o marco regulatório do novo combustível (Portal do Biodiesel, 2006). 


\subsection{Marco Regulatório}

A Presidência da República instituiu, por meio de Decreto, um Grupo de Trabalho Interministerial encarregado de apresentar estudos sobre a viabilidade de utilização de biodiesel como fonte alternativa de energia. Como resultado foi elaborado um relatório que deu embasamento ao Presidente da República para estabelecer o PNPB como ação estratégica e prioritária para o Brasil.

Esse Grupo de Trabalho é constituído pela competência da Comissão Executiva Interministerial (CEIB) para elaborar, implementar e monitorar programa integrado, propor os atos normativos que se fizessem necessários à implantação do Programa, assim como analisar, avaliar e propor outras recomendações e ações, diretrizes e políticas públicas.

O Projeto de lei $n^{\circ} 3.368$, encontrado no Anexo 1, que deu origem ao Programa, formulado em 2004 pelo deputado federal Ariosto Holanda, onde ele dispõe sobre a obrigatoriedade da adição de $2 \%$ de biodiesel ao óleo diesel, sobre o cultivo de oleaginosas a serem utilizadas na fabricação de biodiesel e sobre a sua produção e comercialização.

Esse projeto procura ressaltar a importância da adição desse novo combustível à matriz energética brasileira ao valorizar as produções agrícolas familiares com a criação de empregos no meio rural, além de reduzir o consumo de diesel convencional com ganhos tanto econômico - diante a redução de importações, que correspondem a cerca de $15 \%$ (6 bilhões de litros ao custo de 1,2 bilhões de dólares) - quanto ambientais - diante as reduções nas emissões de dióxido de carbono, óxidos de enxofre e material particulado, além do desenvolvimento da indústria nacional de pesquisa e equipamentos (Inovação tecnológica, 2006).

Também, o Projeto destaca a importância de uma agência específica para controle e fiscalização do biodiesel, assim como sua competência em registro e autorizações de produção do biocombustível, instituindo a ANP - Agência Nacional de Petróleo e Biocombustíveis - para tal.

A partir desse Projeto, então, foi criada a lei no 11.097 de 13 de janeiro de 2005, verificada na íntegra no Anexo 2, que dispõe sobre a introdução de biodiesel na matriz energética, altera leis afins e dá outras providências, tais como estabelecimento de prazos para a inserção do biodiesel ao diesel comum.

A lei $n^{\circ} 11.097 / 2005$ promove a inserção do Programa Nacional de Produção e Uso do Biodiesel, com a observação de alguns critérios, tais como: 
"I - a disponibilidade de oferta de matéria-prima e a capacidade industrial para produção de biodiesel;

II - a participação da agricultura familiar na oferta de matérias-primas;

III - a redução das desigualdades regionais;

IV - o desempenho dos motores com a utilização do combustível;

$\mathrm{V}$ - as políticas industriais e de inovação tecnológica”.

A Figura 2.2 mostra a estrutura do PNPB

A lei também estabelece competência à ANP - Agência Nacional do Petróleo, Gás Natural e Biocombustíveis - como órgão regulador para

"promover a regulação, a contratação e a fiscalização das atividades econômicas integrantes da indústria do petróleo, do gás natural e dos biocombustíveis".

Seus principais objetivos são:

- Implantar um programa sustentável, promovendo inclusão social;

- Garantir preços competitivos, qualidade e suprimento;

- Produzir o biodiesel a partir de diferentes fontes oleaginosas e em regiões diversas.

A Figura 2.1 mostra a Estrutura do Programa.

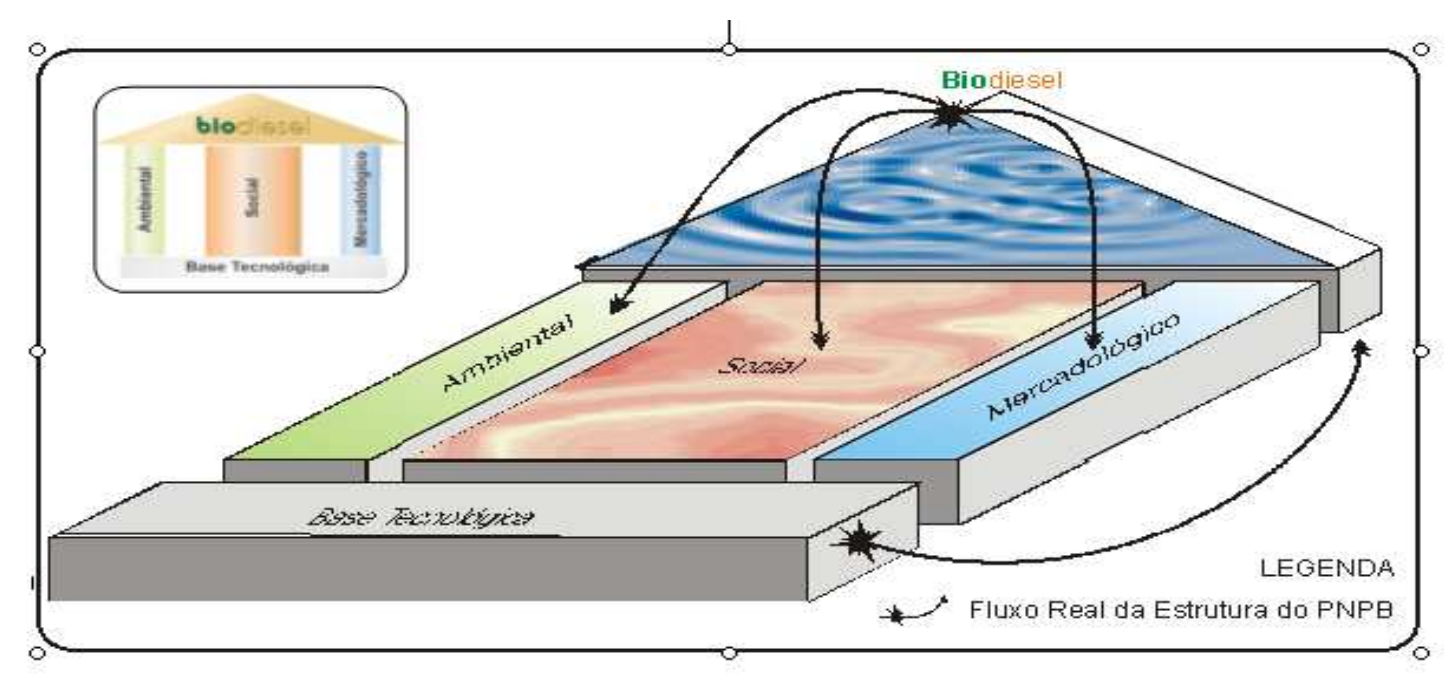

Fonte: Damasceno \& Domingues (2008)

Figura 2.1 - Estrutura do PNPB. 
Atualmente, essas ações estão articuladas por meio de diretrizes, legislações, tributações, entre outras que, por meio da lei $\mathrm{n}^{\mathrm{o}}$ 11.097, de 13 de janeiro de 2005. Inicialmente, propõe a adição do biodiesel ao óleo diesel comercializado em um percentual mínimo obrigatório de 5\% (cinco por cento), em volume, no prazo de 8 (oito) anos a partir de 13 de janeiro de 2005. Entretanto, há um prazo de 3 (três) anos, após essa data, para se utilizar um percentual mínimo obrigatório intermediário de $2 \%$ (dois por cento), em volume.

Interessante notar que o percentual obrigatório de adição de $5 \%$ de biodiesel requerido pelo Programa é a porcentagem de diesel importado pelo Brasil, como atesta na Tabela 2.1 da página 28.

O governo previa a possibilidade de alterar os percentuais de adição disponibilidade de oferta de matéria-prima, capacidade industrial para produção de biodiesel e comportamento da demanda.

Com a Resolução $\mathrm{n}^{\circ} 03$ de setembro de 2005, esse cronograma foi alterado e o Conselho Nacional de Política Energética (CNPE) antecipou a adição de B2, que passou a ser obrigatório entre 2008 e 2010. E o B5 passou a ser obrigatório a partir de 2010.

A Resolução CNPE n ${ }^{\circ} 02$ de março de 2008.

“estabelece em três por cento, em volume, o percentual mínimo obrigatório de adição de biodiesel ao óleo diesel comercializado ao consumidor final, nos termos do art. $2^{\circ}$ da Lei $n^{\circ} 11.097$, de 13 de janeiro de 2005". 4

Nesta resolução a adição passa a ser mandatória de 3\% de biodiesel ao diesel mineral a partir de $1^{\circ}$ de julho de 2008.Um ano depois, em abril de 2009, a Resolução novamente se altera e

“estabelece em quatro por cento, em volume, o percentual mínimo obrigatório de adição de biodiesel ao óleo diesel comercializado ao consumidor final, nos termos do art. $2^{\circ}$ da Lei $n^{\circ} 11.097$, de 13 de janeiro de $2005 \%$.

Diante a oferta e a demanda, a lei novamente se altera com adição de $4 \%$ de biodiesel ao diesel mineral a partir de $1^{\circ}$ de julho de 2009. Dessa forma houve redução da

\footnotetext{
${ }^{4}$ Resolução CNPE n ${ }^{\circ} 02$ de 13/03/2008, disponível em www.mme.gov.br, acessado em dez/2009

${ }^{5}$ Resolução CNPE n ${ }^{\circ} 02$ de 27/04/2009, disponível em www.mme.gov.br, acessado em dez/2009.
} 
participação de óleo diesel na matriz energética, contribuindo para menor importação desse insumo.

De acordo com dados estatísticos da ANP (2009), até outubro de 2009 a importação de óleo diesel respondeu a cerca de 17 milhões de barris, 15 milhões de barris a menos que a importação registrada em 2007. Isso corresponde a um dispêndio de um pouco mais de US\$ 1 trilhão e 255 milhões, o que responde a uma economia de US\$ 1 trilhão e 700 milhões. ${ }^{6}$

Para melhor entender as leis, decretos, portarias e instruções normativas que disciplinam o segmento da produção e utilização de biodiesel no Brasil, segue o quadro 2.1 que está dividido cronologicamente.

\footnotetext{
${ }^{6}$ Dados estatísticos disponíveis em www.anp.gov.br, acessado em dez/2009.
} 


\section{Quadro 2.1 - Relação de leis, decretos, portarias e instruções normativas que disciplinam o segmento do biodiesel no Brasil.}

\begin{tabular}{|c|c|c|}
\hline Ato & Tema & Assunto \\
\hline $\begin{array}{l}\text { Decreto de } 02 \\
\text { de julho de } \\
2003\end{array}$ & $\begin{array}{l}\text { Pré-programa } \\
\text { Nacional de } \\
\text { Biodiesel }\end{array}$ & $\begin{array}{l}\text { Institui o Grupo de Trabalho Interministerial encarregado de } \\
\text { apresentar estudos sobre a viabilidade de utilização de óleo } \\
\text { vegetal (e/ou biodiesel) como fonte de energia alternativa, } \\
\text { propondo, caso necessário, as ações necessárias para o uso de } \\
\text { biodiesel. }\end{array}$ \\
\hline $\begin{array}{l}\text { Portaria ANP } \\
240, \text { de } 25 \text { de } \\
\text { agosto de } 2003 .\end{array}$ & $\begin{array}{l}\text { Utilização de } \\
\text { combustíveis }\end{array}$ & $\begin{array}{l}\text { Estabelece a regulamentação para a utilização de combustíveis } \\
\text { sólidos, líquidos ou gasosos não específicos no país. }\end{array}$ \\
\hline $\begin{array}{l}\text { Decreto de } 23 \\
\text { de dezembro de } \\
2003\end{array}$ & $\begin{array}{l}\text { Pré-programa } \\
\text { Nacional de } \\
\text { Biodiesel }\end{array}$ & $\begin{array}{l}\text { Institui a Comissão Executiva Interministerial encarregada da } \\
\text { implantação das ações direcionadas produção e uso de óleo } \\
\text { vegetal - biodiesel - como fonte de energia alternativa }\end{array}$ \\
\hline $\begin{array}{l}\text { Resolução } \\
\text { ANP n } 41 \text {, de } \\
24 \text { de } \\
\text { novembro de } \\
2004\end{array}$ & $\begin{array}{l}\text { Agência } \\
\text { Regulatória do } \\
\text { Mercado de } \\
\text { biodiesel }\end{array}$ & $\begin{array}{l}\text { Fica instituída a regulamentação e a obrigatoriedade de } \\
\text { autorização da ANP para o exercício da atividade de produção } \\
\text { de biodiesel }\end{array}$ \\
\hline $\begin{array}{l}\text { Resolução } \\
\text { ANP n42, de } \\
24 \text { de } \\
\text { novembro de } \\
2004\end{array}$ & $\begin{array}{l}\text { Comercia- } \\
\text { lização }\end{array}$ & $\begin{array}{l}\text { Estabelece a especificação para comercialização de biodiesel } \\
\text { que deverá ser adicionado ao óleo diesel na proporção de } 2 \% \text { em } \\
\text { volume }\end{array}$ \\
\hline $\begin{array}{l}\text { Decreto } \\
\mathrm{n}^{\circ} 5.297 \text { de } 06 \\
\text { de dezembro de } \\
2004 .\end{array}$ & Tributação & $\begin{array}{l}\text { Dispõe sobre os coeficientes de redução de alíquota de } \\
\text { contribuição para o PIS/Pasep e da Cofins, incidentes na } \\
\text { produção e comercialização de biodiesel, sobre os termos e as } \\
\text { condições para utilização das alíquotas diferenciadas, e dá outras } \\
\text { providências. }\end{array}$ \\
\hline $\begin{array}{l}\text { Lei } n^{\circ} 11.097 \\
\text { de } 13 \text { de } \\
\text { janeiro de } \\
2005 .\end{array}$ & $\begin{array}{l}\text { Abertura do } \\
\text { mercado para o } \\
\text { biodiesel }\end{array}$ & $\begin{array}{l}\text { Dispõe sobre a introdução do biodiesel na matriz energética } \\
\text { brasileira; altera as leis } 9.478 \text {, de } 06 \text { de agosto de } 1997 ; 9.847 \text { de } \\
26 \text { de outubro de } 1999 ; \text { e } 10.636 \text { de } 30 \text { de dezembro de } 2002 \text {, e } \\
\text { dá outras providências. }\end{array}$ \\
\hline $\begin{array}{l}\text { Instrução } \\
\text { Normativa SRF } \\
n^{\circ} 516, \text { de } 22 \\
\text { de fevereiro de } \\
2005 .\end{array}$ & Tributação & $\begin{array}{l}\text { Dispõe sobre o Registro Especial a que estão sujeitos os } \\
\text { produtores e os importadores de biodiesel, e dá outras } \\
\text { providências. }\end{array}$ \\
\hline $\begin{array}{l}\text { Instrução } \\
\text { Normativa SRF } \\
\mathrm{n}^{\circ} 526 \text {, de } 15 \\
\text { de março de } \\
2005 .\end{array}$ & Tributação & $\begin{array}{l}\text { Dispõe sobre a opção dos regimes de incidência da contribuição } \\
\text { do PIS/Pasep e da Cofins, de que se tratam o artigo } 52 \text { da lei n } \\
10.833 \text {, de } 29 \text { de dezembro de } 2003 \text {, o art. } 23 \text { da lei } 10.865 \text {, de } 30 \\
\text { de abril de } 2004 \text { e o ar. } 4^{\circ} \text { da Medida Provisória n }{ }^{\circ} 227 \text {, de } 06 \text { de } \\
\text { dezembro de } 2004 \text {. }\end{array}$ \\
\hline
\end{tabular}




\begin{tabular}{|c|c|c|}
\hline $\begin{array}{l}\text { Lei } \mathrm{n}^{\circ} 11.116 \text {, } \\
\text { de } 18 \text { de maio } \\
\text { de } 2005 \text {. }\end{array}$ & Tributação & $\begin{array}{l}\text { Dispõe sobre o Registro Especial, na Secretaria da Receita } \\
\text { Federal do Ministério da Fazenda, de produtor ou importador de } \\
\text { biodiesel e sobre a incidência da contribuição para o PIS/Pasep e } \\
\text { da Cofins, sobre as receitas decorrentes da venda desse produto; } \\
\text { altera as leis } n^{\circ} 10.451 \text {, de } 10 \text { de maio de } 2002 \text { e } 11.097 \text { de } 13 \text { de } \\
\text { janeiro de } 2005 \text {, e dá outras providências. }\end{array}$ \\
\hline $\begin{array}{l}\text { Decreto } n^{\circ} \text {. } \\
5.448 \text { de } 20 \text { de } \\
\text { maio de } 2005\end{array}$ & $\begin{array}{l}\text { Abertura do } \\
\text { mercado para o } \\
\text { biodiesel }\end{array}$ & $\begin{array}{l}\text { Regulamenta o parágrafo } 1^{\circ} \text { do artigo } 2^{\circ} \text { da lei } n^{\circ} 11.097 \text {, de } 13 \\
\text { de janeiro de } 2005 \text {, que dispõe sobre a introdução de biodiesel } \\
\text { na matriz energética brasileira, e dá outras providências. }\end{array}$ \\
\hline $\begin{array}{l}\text { Decreto } 5.457 \text {, } \\
\text { de } 06 \text { de junho } \\
\text { de } 2005 .\end{array}$ & Tributação & $\begin{array}{l}\text { Reduz as alíquotas da contribuição para o PIS/Pasep e da Cofins } \\
\text { incidente sobre a importação e a comercialização de biodiesel. }\end{array}$ \\
\hline $\begin{array}{l}\text { Instrução } \\
\text { Normativa } \\
\text { MDA n }{ }^{\circ} 01 \text {, de } \\
05 \text { de julho de } \\
2005 .\end{array}$ & $\begin{array}{l}\text { Selo } \\
\text { Combustível } \\
\text { Social }\end{array}$ & $\begin{array}{l}\text { Dispõe sobre os critérios e procedimentos relativos a concessão } \\
\text { de uso de Selo Combustível Social }\end{array}$ \\
\hline $\begin{array}{l}\text { Resolução } \\
\text { CNPE n³, 23 } \\
\text { de setembro de } \\
2005 .\end{array}$ & Mercado & $\begin{array}{l}\text { Reduz o prazo de que trata o parágrafo } 1^{\circ} \text { do artigo }{ }^{\circ} \text { da lei } \\
11.091 \text {, de } 13 \text { de janeiro de } 2005 \text {, e dá outras providências. }\end{array}$ \\
\hline $\begin{array}{l}\text { Instrução } \\
\text { Normativa } \\
\text { MDA n }{ }^{\circ} 02 \text {, de } \\
30 \text { de setembro } \\
\text { de } 2005 \text {. }\end{array}$ & $\begin{array}{l}\text { Selo } \\
\text { Combustível } \\
\text { Social }\end{array}$ & $\begin{array}{l}\text { Dispõe sobre os critérios e procedimentos relativos ao } \\
\text { enquadramento de projetos e produção de biodiesel ao Selo } \\
\text { Combustível Social. }\end{array}$ \\
\hline $\begin{array}{l}\text { Resolução } \\
\text { ANP n³1, de } \\
04 \text { de } \\
\text { novembro de } \\
2005 .\end{array}$ & Mercado & $\begin{array}{l}\text { Regula a realização de leilões públicos para aquisição de } \\
\text { biodiesel. }\end{array}$ \\
\hline $\begin{array}{l}\text { Resolução } \\
\text { CNPE n } 02 \text { de } \\
13 \text { de março de } \\
2008\end{array}$ & Mercado & $\begin{array}{l}\text { Estabelece em três por cento, em volume, o percentual } \\
\text { mínimo obrigatório de adição de biodiesel ao óleo diesel } \\
\text { comercializado ao consumidor final, nos termos do art. } 2^{\circ} \\
\text { da Lei } \mathrm{n}^{\circ} 11.097 \text {, de } 13 \text { de janeiro de } 2005 \text {. }\end{array}$ \\
\hline $\begin{array}{l}\text { Resolução } \\
\text { CNPE n } 02 \text { de } \\
27 \text { de abril de } \\
2009 .\end{array}$ & Mercado & $\begin{array}{l}\text { Estabelece em quatro por cento, em volume, o percentual } \\
\text { mínimo obrigatório de adição de biodiesel ao óleo diesel } \\
\text { comercializado ao consumidor final, nos termos do art. } 2^{\circ} \\
\text { da Lei } \text { n }^{\circ} 11.097 \text {, de } 13 \text { de janeiro de } 2005 \text {. }\end{array}$ \\
\hline
\end{tabular}

Fonte: Elaboração própria com base nos decretos, leis e resoluções referente ao PNPB. 


\subsection{Estrutura econômica do PNPB}

Em relação aos encargos financeiros, o BNDES - Banco Nacional de Desenvolvimento Econômico e Social - deve criar linha de crédito específica para o financiamento das instalações das cooperativas ou associações de pequenos agricultores, e o Banco do Brasil S.A., o Banco do Nordeste S.A. e o Banco da Amazônia S.A. devem criar linhas de crédito específicas para o cultivo de oleaginosas pelas unidades familiares (Bermann, 2007).

O BNDES criou o Programa de Apoio Financeiro a Investimentos em Biodiesel que pretende financiar a construção da infra-estrutura industrial para a produção do novo combustível, desde o processamento das oleaginosas, até o armazenamento e a distribuição. Os recursos serão liberados à medida que os projetos cheguem aos bancos e sejam aprovados (Chiaranda, 2005).

Serão aprovados pelo BNDES até $90 \%$ dos itens em projetos que contemplem a inclusão social e até $80 \%$ para os demais projetos. Também foi ampliado em $25 \%$ o prazo total de financiamento para máquinas e equipamentos com motores preparados para usar uma mistura de, pelo menos, 20\% de biodiesel ou óleo bruto vegetal (ABDL, 2006).

De acordo com o Superintendente de Abastecimento e Coordenador de Biodiesel e etanol da ANP - Agência Nacional de Petróleo, Roberto Furian Ardenghy, ainda há disponibilidade de linhas de crédito do BNDES e Banco do Brasil específicas para novos empreendimentos na produção de biodiesel, com juros baixos, como indicado no quadro 2.2, que demonstra o programa de apoio financeiro a investimentos do biodiesel. 


\section{Quadro 2.2 - Programa de Apoio Financeiro a Investimentos do Biodiesel}

\begin{tabular}{|c|c|c|c|}
\hline Finalidade & $\begin{array}{l}\text { Participação do } \\
\text { BNDES }\end{array}$ & Custo de Operação & Garantias \\
\hline $\begin{array}{l}\text { Investimento em todas } \\
\text { as fases do biodiesel } \\
\text { (fase agrícola, produção } \\
\text { de óleo bruto, produção } \\
\text { de biodiesel, } \\
\text { armazenamento, } \\
\text { logística e } \\
\text { equipamentos para a } \\
\text { produção de biodiesel), } \\
\text { sendo que, em relação } \\
\text { às fases agrícola e de } \\
\text { produção de óleo bruto, } \\
\text { podem ser apoiados } \\
\text { projetos desvinculados } \\
\text { da produção imediata de } \\
\text { biodiesel desde que seja } \\
\text { formalmente } \\
\text { demonstrada a } \\
\text { destinação futura do } \\
\text { projeto agrícola ou do } \\
\text { óleo bruto para a } \\
\text { produção de biodiesel. } \\
\text { Aquisição de máquinas } \\
\text { e equipamentos } \\
\text { homologados para uso } \\
\text { de biodiesel ou de óleo } \\
\text { vegetal bruto. } \\
\text { Investimentos em } \\
\text { beneficiamento de co- } \\
\text { produtos e subprodutos } \\
\text { de biodiesel. }\end{array}$ & $\begin{array}{l}\text { Até } 90 \% \text { (noventa } \\
\text { por cento) dos } \\
\text { itens de apoio } \\
\text { para projetos com } \\
\text { Selo Combustível } \\
\text { Social } \\
\\
\text { Até } 80 \% \text { (oitenta } \\
\text { por cento) dos } \\
\text { itens de apoio } \\
\text { para projetos sem } \\
\text { o Selo } \\
\text { Combustível } \\
\text { Social. }\end{array}$ & $\begin{array}{l}\text { Micro, pequenas e médias } \\
\text { empresas, apresentando projetos } \\
\text { com Selo Combustível Social: } \\
\text { TJLP + 1\% a.a. } \\
\text { Micro, pequenas e médias } \\
\text { empresas, apresentando projetos } \\
\text { sem Selo Combustível Social: } \\
\text { TJLP + 2\% a.a. } \\
\text { Grandes empresas apresentando } \\
\text { projetos com Selo Combustível } \\
\text { Social: TJLP + 2\% a.a. } \\
\text { Grandes empresas apresentando } \\
\text { projetos sem Selo Combustível } \\
\text { Social: TJLP + 3\% a.a }\end{array}$ & $\begin{array}{l}\text { As garantias exigidas serão } \\
\text { definidas de acordo com as } \\
\text { Políticas Operacionais do } \\
\text { BNDES } \\
\text { No caso de hipoteca, } \\
\text { penhor (inclusive de títulos) } \\
\text { e/ou alienação fiduciária, o } \\
\text { valor de garanta deve ser } \\
\text { correspondente, no mínimo, } \\
\text { a 100\% (cem por cento) do } \\
\text { valor da colaboração } \\
\text { financeira. } \\
\\
\text { Na fase de operação, } \\
\text { poderá haver dispensa, sob } \\
\text { condições, de garantia real } \\
\text { e pessoal, se houver em } \\
\text { favor do BNDES e/ou dos } \\
\text { agentes financeiros, } \\
\text { vinculação de receitas } \\
\text { provenientes de Contrato de } \\
\text { Compra e Venda de } \\
\text { Biodiesel. }\end{array}$ \\
\hline
\end{tabular}

Fonte: Abiodiesel, 2006.

Os incentivos são auxílio em capital que o governo oferece sem esperar contraprestação econômica alguma por parte da pessoa que é beneficiada. Os órgãos financiadores entregam de maneira seletiva e temporal, sendo responsabilidade do governo selecionar objetivamente, as pessoas a serem beneficiadas e o valor do incentivo, assim como os requisitos e as condições que devem cumprir o solicitante (Abiodiesel, 2006).

No Brasil, os agricultores contam com regime tributário especial para o novo combustível, como a redução de alíquotas de PIS/Pasep e Cofins que varia de acordo com a região, a oleaginosa utilizada e a categoria de produção (agronegócio e agricultura familiar), a isenção do Imposto sobre Produtos Industrializados (IPI) e a possibilidade de 
participação nos leilões de aquisições de biodiesel organizados pela ANP (Portal do Biodiesel, 2006).

Uma característica comum em termos de impostos é que o biodiesel é o Selo Combustível Social, também é parte das regras tributárias do programa, conforme pode ser visualizado no quadro 2.3 .

\section{Quadro 2.3 - Características tributárias do PNPB}

\begin{tabular}{|c|c|c|c|c|c|}
\hline \multirow[b]{2}{*}{$\begin{array}{l}\text { Tributos } \\
\text { federais }\end{array}$} & \multicolumn{4}{|c|}{ Biodiesel } & \multirow[b]{2}{*}{$\begin{array}{l}\text { Diesel de } \\
\text { Petróleo }\end{array}$} \\
\hline & $\begin{array}{c}\text { Agricultura Familiar } \\
\text { nas regiões N e NE, e } \\
\text { Semi-árido, com } \\
\text { mamona ou palma }\end{array}$ & $\begin{array}{l}\text { Agricultur } \\
\text { a Familiar }\end{array}$ & $\begin{array}{l}\text { Regiões N e NE, e } \\
\text { Semi-árido, com } \\
\text { mamona ou palma }\end{array}$ & $\begin{array}{l}\text { Regra } \\
\text { Geral }\end{array}$ & \\
\hline IPI & Alíquota Zero & $\begin{array}{l}\text { Alíquota } \\
\text { Zero }\end{array}$ & Alíquota Zero & $\begin{array}{l}\text { Alíquota } \\
\text { Zero }\end{array}$ & $\begin{array}{l}\text { Alíquota } \\
\text { Zero }\end{array}$ \\
\hline CIDE & Inexistente & Inexistente & Inexistente & Inexistente & $\mathrm{R} \$ 0,070$ \\
\hline $\begin{array}{l}\text { PIS/COF } \\
\text { INS }\end{array}$ & Redução de $100 \%$ & $\begin{array}{l}\text { Redução } \\
\text { de } 68 \%\end{array}$ & Redução de $32 \%$ & $\begin{array}{l}\leq \text { diesel } \\
\text { mineral }\end{array}$ & $\mathrm{R} \$ 0,148$ \\
\hline $\begin{array}{l}\text { Total } \\
\text { tributos } \\
\text { federais }\end{array}$ & $\begin{array}{l}\text { R \$litro } \\
\text { R \$ 0,00 }\end{array}$ & $\begin{array}{l}\text { R\$/litro } \\
\mathrm{R} \$ 0,070\end{array}$ & $\begin{array}{l}\text { R \$litro } \\
\mathrm{R} \$ 0,151\end{array}$ & $\begin{array}{l}\text { R \$/litro } \\
\mathrm{R} \$ 0,218\end{array}$ & $\begin{array}{l}\text { R\$/litro } \\
\mathrm{R} \$ 0,218\end{array}$ \\
\hline
\end{tabular}

Legenda: IPI: Imposto sobre Produtos Industrializados; CIDE: Contribuição de Intervenção no Domínio Econômico.

Fonte: Bermann, 2007

Os custos de produção do biodiesel dependem do óleo vegetal, dos custos de transformação industrial e transporte. Em geral, o custo do óleo vegetal corresponde a aproximadamente $85 \%$ do custo do biodiesel, quando este é produzido em plantas de alta capacidade (Bermann, 2007).

A diferença entre custos de produção do diesel, sem impostos, e custos de oportunidade, que são os valores pagos no mercado internacional para os óleos vegetais, indica o valor do subsídio a ser pago diretamente ou por meio de renúncia fiscal. Mesmo no caso da soja, que conta com um subsídio mínimo, apenas a renúncia fiscal não seria suficiente para atingir o valor ideal para a incorporação do biodiesel como alternativa econômica ao óleo mineral. O óleo de dendê apresenta custo de produção baixo, 
equivalente ao do diesel mineral, sem impostos. Mas o maior custo de oportunidade do óleo torna necessário um subsídio direto mais elevado que o da soja (Bermann, 2007).

O programa de biodiesel prevê que o combustível seja comprado pelas refinarias por meio de leilões promovidos pela ANP. Esses leilões podem exigir ou não que as empresas participantes tenham o selo, como aconteceu nos quatro leilões já realizados.

O objetivo desse formato de compra prévia do biodiesel é garantir aos produtores e aos agricultores um mercado para a venda da produção. Afinal, o fabricante já pode iniciar a produção sabendo quanto poderá vender, correndo, portanto, menos riscos. O sistema também é favorável do lado do mercado consumidor, já que garante, com antecedência, a disponibilidade do combustível. A definição das datas dos leilões é feita pelo governo federal. (Abiodiesel, 2006)

Após a contratação, a entrega do biodiesel é feita diretamente pelos produtores às distribuidoras, em cujas instalações ocorre a mistura. A diferença entre o preço do diesel de refinaria e do biodiesel é dividida entre todos os litros de diesel vendidos para os consumidores. Ou seja, se o biodiesel é negociado a $\mathrm{R} \$ 2,40$ por litro e o litro do diesel derivado de petróleo custa $R$ \$1,40 para a refinaria, a diferença de $R$ \$1,00 é repassada para todos os litros de diesel comercializados, incluam ou não o combustível de origem vegetal, logo, a diferença é repassada ao consumidor (Ardenghy, 2007).

O preço final do produto ao consumidor varia em relação à proporção de diesel utilizada, mas seu custo na bomba será dado pela seguinte equação:

\section{Preço na bomba $=$ preço do biodiesel puro com $\mathrm{X} \%$ do biodiesel utilizado + preço do diesel mineral com $\mathrm{X} \%$ do diesel utilizado.}

Assim, o impacto do custo do biodiesel no preço final do produto será diretamente proporcional a sua participação na mistura. Como os preços dos combustíveis estão liberados no Brasil, existe uma razoável variação entre as regiões, que pode abrir oportunidades mais interessantes para o uso de biocombustíveis nos mercados onde os diferenciais de preço frente ao diesel forem menores.

Nesta direção, deve-se observar que os valores de realização do diesel, aos quais se agregam os tributos estaduais, fretes e margens na formação do preço para o consumidor têm sido cerca de 5\% inferiores no Nordeste, e $4 \%$ maiores no Centro-oeste, isto devido à paridade de preços com o mercado internacional, e à distância desses mercados das fontes de fornecimento. 


\subsection{Estrutura produtiva do PNPB}

O mercado de biodiesel é realizado por meio de leilões. Entre as 23 empresas ganhadoras, há várias que fazem parte do mesmo complexo industrial, com a Brasil biodiesel que participa no Norte e Nordeste. Porém, há uma quantidade maior de participantes no Sudeste e Centro-Oeste

O Quadro 2.4 indica os resultados dos leilões realizados pela ANP Nesse quadro é possível verificar que os empreendimentos que utilizam soja como matéria-prima, respondem a cerca de $14 \%$ do volume total contratado nos leilões 
Quadro 2.4 - Resultado dos leilões realizados pela ANP

\begin{tabular}{|c|c|c|}
\hline Empresa e sede & $\begin{array}{c}\text { Volume } \\
\text { contratado } \\
\left(\mathrm{m}^{3}\right)\end{array}$ & Oleaginosas usadas \\
\hline Agropalma - Belém (PA) & 7.200 & Óleo de palma \\
\hline Agrosoja - Sorriso (MT) & 5.000 & Soja \\
\hline Barrálcool - Barra dos Bugres (MT) & 16.629 & nabo forrajeiro, girassol e pinhão manso \\
\hline Binatural - Formosa (GO) & 1.320 & girassol, nabo forrajeiro e pinhão manso \\
\hline Biocapital - Charqueada (SP) & 60.000 & $\begin{array}{l}\text { soja, girassol, amendoim, mamona, nabo } \\
\text { forrageiro, pinhão manso }\end{array}$ \\
\hline Biominas - Itatiaiuçu (MG) ${ }^{\star}$ & 2.651 & $\mathrm{Nd}$ \\
\hline Brasil Biodiesel - Floriano (PI) & 78.000 & Mamona \\
\hline Brasil Biodiesel - Crateús (CE) & 90.000 & Mamona \\
\hline Brasil Biodiesel - Porto Nacional (TO) & 90.000 & Mamona \\
\hline Brasil Biodiesel - Rosário do Sul (RS) & 80.000 & mamona e girassol \\
\hline $\begin{array}{l}\text { Brasil Biodiesel - São Luís (MA) } \\
\text { Brasil Biodiesel - }\end{array}$ & 50.000 & Mamona \\
\hline Itaquara/Morro do Chapéu (BA) & 100.000 & Mamona \\
\hline Bsbios - Passo Fundo (RS) & 70.000 & soja, girassol e canola \\
\hline Caramuru - São Simão (GO) & 30.000 & soja, milho, girassol e canola \\
\hline Fertibom - Catanduva (SP) & 6.000 & $\begin{array}{l}\text { pinhão-manso, girassol, } \\
\text { mamona, soja e amendoim }\end{array}$ \\
\hline Fiagril - Lucas do Rio Verde (MT) & 27.500 & soja $(70 \%)$ e sebo bovino (30\%) \\
\hline Granol - Campinas (SP) & 20.100 & Soja \\
\hline Granol - Anápolis (GO) & 36.000 & Soja \\
\hline Oleoplan - Veranópolis (RS) & 10.000 & Soja \\
\hline Ponte di Ferro - Rio de Janeiro (RJ) & 31.000 & sebo bovino \\
\hline Ponte di Ferro - Taubaté (SP) & 19.000 & Soja \\
\hline Renobrás - Dom Aquino (MT) & 900 & soja, girassol e nabo forrageiro \\
\hline Soyminas - Cássia (MG) & 8.700 & Soja \\
\hline TOTAL & 840.000 & \\
\hline
\end{tabular}

Fonte: Bermann (2007), p. 47. Elaboração com base em informações da ANP e empresas.

A distribuição espacial das usinas de biodiesel é retratada na figura 2.3. Essa figura e a análise da tabela que a compõe, permite verificar que mais de $50 \%$ dos das usinas de biodiesel estão localizadas na região Nordeste e Centro-oeste, porém concentradas na mão de grandes empresas como a Brasil Biodiesel. 


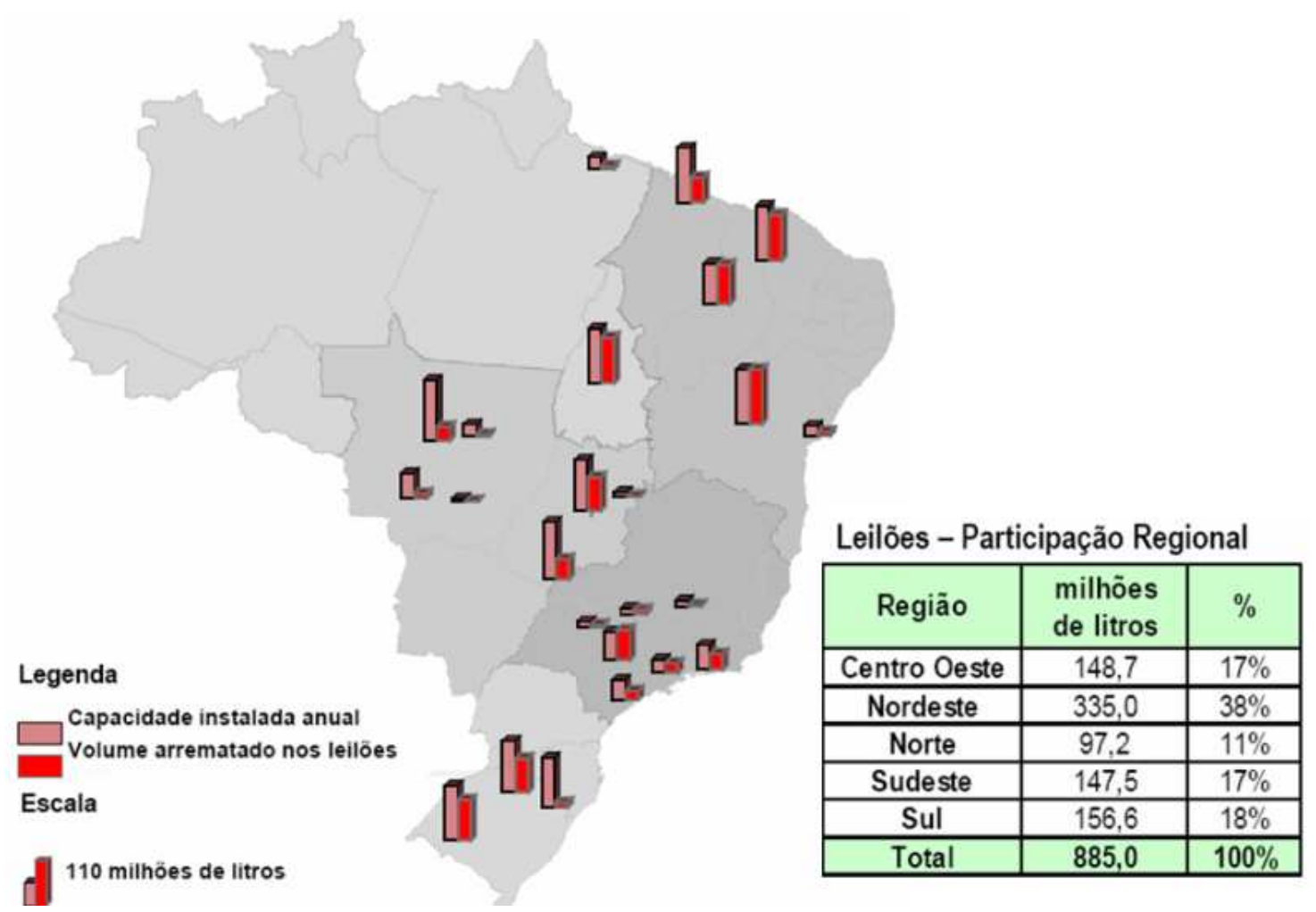

Fonte: MDA, $2007^{7}$

Figura 2.2 - Usinas de Biodiesel vencedoras de leilões

As empresas que produzem biodiesel podem adquirir, junto a ANP o Selo Combustível Social. Esse Selo, dado aos produtores de biodiesel que adquirirem determinadas quantidades das matérias-primas de agricultores familiares, tem por objetivo estimular a participação da agricultura familiar no programa e garantir o cumprimento de um de seus objetivos - gerar renda no campo.

A tabela 2.2 identifica as principais características do empreendimento para obter o selo.

\footnotetext{
${ }^{7}$ Apresentação realizada pela Secretaria de Agricultura Familar do MDA no Seminário Agrocombustíveis e Agricultura Familiar e Camponesa, no Rio de Janeiro em julho de 2007.
} 
Tabela 2.2 - Participação mínima de agricultura familiar entre os fornecedores de matéria-prima para a obtenção do Selo Combustível Social

\begin{tabular}{ccc}
\hline Região & $\begin{array}{c}\text { Participação de Agricultura } \\
\text { Familiar (\%) }\end{array}$ & $\begin{array}{c}\text { Participação de Agricultura } \\
\text { Intensiva (\%) }\end{array}$ \\
\hline Norte & 10 & 90 \\
Nordeste e Semi-Árido & 50 & 50 \\
Centro-Oeste & 10 & 90 \\
Sudeste & 30 & 70 \\
Sul & 30 & 70 \\
\hline
\end{tabular}

Fonte: Bermann, 2007

As empresas interessadas devem solicitar o Selo Combustível Social ao Ministério do Desenvolvimento Agrário (MDA). Os percentuais mínimos descritos na Tabela 2.2 são calculados sobre o custo da matéria-prima adquirida do produtor familiar ou cooperativa agropecuária em relação ao custo das aquisições anuais totais feitas pelo produtor de biodiesel.

Esses critérios estão estabelecidos na Instrução Normativa $n^{0} 1$ do MDA, na qual também estão estabelecidas outras formas de compra de matéria-prima, como, por exemplo, de meeiros e também a possibilidade de uso de matéria-prima de produção própria. Além disso, essa instrução prevê que o produtor de biodiesel deve prestar assistência técnica e de capacitação aos agricultores familiares com o objetivo de contribuir para a sua melhor inserção da cadeia produtiva.

Para obter o selo, o produtor de biodiesel tem que celebrar contratos com todos os fornecedores de matérias-primas previamente. Esses contratos devem incluir uma terceira entidade para aumentar as garantias dos produtores rurais. Essa entidade pode ser um sindicato de trabalhadores rurais ou de trabalhadores na agricultura familiar.

Outras possibilidades são as federações filiadas à Confederação Nacional dos Trabalhadores na Agricultura (Contag), à Federação dos Trabalhadores da Agricultura Familiar (Fetraf) ou à Associação Nacional dos Pequenos Agricultores (ANPA), entre outras instituições credenciadas pelo MDA.

A fiscalização do Selo Combustível Social poderá ser feita no produtor de biodiesel, no agricultor familiar fornecedor da matéria-prima, ou nos sindicatos e federações listados no parágrafo anterior. É feita por meio da análise das notas fiscais de compra de matériasprimas ou contratos entre as partes, ou registros de ATER (Assistência Técnica e Extensão Rural) pelo próprio MDA, empresa contratada para esse fim ou banco, desde que estejam 
enquadrados em projetos sociais, mediante Termo de Cooperação Técnica (TCT) com o MDA.

Essas informações são cruzadas entre si e com os dados existentes no MDA. Foi definido pelo MDA que essa avaliação será feita na concessão do selo, a cada ano civil ou a qualquer tempo se houver indícios de irregularidades.

A assistência técnica aos agricultores também é fiscalizada através de registros de visitas, reuniões, atas, listas de presença, fotos, comprovação fiscal de gastos (registro funcionários, pagamento salários, notas de serviços de terceiros) e contratos de prestação de serviços e TCTs com empresas públicas.

Até agora, o biodiesel foi comprado dos produtores por meio de leilões promovidos pela ANP. Todos os quatro leilões realizados exigiram que as empresas participantes tivessem o Selo. A partir de 2008, quando a mistura de $2 \%$ de biodiesel passou a ser obrigatória, as negociações foram feitas diretamente entre produtores e distribuidoras de combustíveis. Desse modo, não necessariamente foi mantida a exigência do Selo para todos os produtores.

Os leilões são feitos por sistema reverso, ou seja, é estabelecido um preço máximo e os ofertantes apresentam propostas de preços menores pelos quais aceitam vender seu produto. $\mathrm{O}$ sistema, semelhante ao utilizado atualmente para a contratação de energia elétrica e de linhas de transmissão de energia, apresenta a vantagem de permitir que se pague o menor preço possível (aceito pelo produtor) pelo produto em negociação.

Ao longo desse estudo isso será comprovado ao demonstrar os diferentes preços pelo qual o biodiesel foi adquirido nas usinas visitadas. É importante citar que, por enquanto, a Petrobrás é responsável pela retirada e transporte do produto da usina, não havendo gastos com fretes e logística. Ao longo do tempo, a tendência é que haja abertura do mercado, esses custos serão repassados ao vendedor, que deverá embutir esse ônus no preço do biodiesel. 


\subsection{Avaliação crítica ao PNPB}

Portanto, o Programa Nacional de Produção e Uso de Biodiesel apresenta vantagens ao estimular o uso de combustíveis alternativos, diminuir a dependência de combustíveis fósseis, ao desenvolver tecnologias ambientalmente benéficas (estímulo ao mercado de créditos de carbono, por exemplo) e partir de uma política pública de incentivo ao desenvolvimento no campo e inclusão social.

Porém, há algumas críticas que podem ser feitas ao PNPB como: a utilização do grão de soja como base para o mercado de produção do biodiesel, restringindo a viabilidade de outras matérias-primas existentes; início abrupto do programa do biodiesel sem definição de ações passo-a-passo e estratégias de ação por parte do governo; e construção do programa de biodiesel de forma paternalista não sendo regulada pelo mercado como acontece com o etanol.

Para melhor atender o mercado e seus objetivos, pesquisas sobre matérias-primas variadas devem ser estimuladas para que possam atender as premissas de produção em pequenas propriedades e estimular a agricultura familiar, visto que a soja é uma cultura preponderantemente monocultora e agrega pouca mão-de-obra por ser tipicamente mecanizada.

Como o mercado mundial de biocombustíveis está em expansão, há necessidade de pesquisas acerca de matérias-primas que viabilizem a produção em grande escala. Falta domínio tecnológico e infra-estrutura logística.

No Brasil, a produção de biodiesel pode representar uma expansão da produção agrícola e geração de postos de trabalho no campo. Porém, há necessidade de políticas públicas para a implementação efetiva do programa de biodiesel, como uma carga tributária diferenciada, estimulando a competitividade; assegurando a regulamentação da produção do biodiesel, visando padronização e garantia de qualidade. (Damasceno \& Domingues, 2008).

Mesmo porque, de acordo com Brien (2009), o biodiesel sempre representará um custo significativo para a sociedade já que seus gastos não o tornam competitivo. Mas como a tendência é o aumento do preço do petróleo e diminuição no preço do óleo de soja, há interesse no biodiesel.

Para que o biodiesel se torne um vetor de desenvolvimento, gerando empregos, renda e energia em bases sustentáveis, é importante que seja implantada uma política 
ampla, levando em conta as dotações regionais, as culturas melhores adaptadas, a infraestrutura existente e, também, que seja garantida a produção/distribuição do biodiesel em todas as regiões brasileiras. (Damasceno \& Domingues, 2008).

O principal erro de estratégia do PNPB consiste em pensar a construção do elo agrícola da cadeia produtiva do biodiesel em base a sistemas agrícolas tradicionais e pouco tecnificados. Deve haver incentivo à implementação de políticas que promovam a formação de cooperativas de pequenos produtores que atuem em todos os sentidos da cadeia de produção do biodiesel, gerando empregos de qualidade, de modo a permitir a implantação de uma estratégia de desenvolvimento ambientalmente sustentável, economicamente sustentada e socialmente inclusiva no campo.

Grande parte do biodiesel adquirido nos leilões tem como matéria-prima a soja. O Capítulo 3 que se segue trata da cultura de soja no Brasil, com seu histórico, impactos e distribuição espacial no país. 


\section{A CULTURA DE SOJA NO BRASIL E O PNPB}

\subsection{Evolução da Produção de soja}

Impulsionada pela expansão da demanda, principalmente internacional, lavoura de soja começou a se expandir mais vigorosamente no Brasil na segunda metade dos anos 70 . Essa expansão atingiu principalmente os estados do sul do país, em regiões de ocupação agrícola antiga, onde a soja passou a ocupar áreas antes exploradas com outras lavouras ou áreas de pastagem.

Ela começou a ser cultivada no Rio Grande do Sul, como uma opção de rotação com o trigo. Depois de assentada nesse estado, expandiu-se para o norte, chegando a Santa Catarina, Paraná e São Paulo (Mueller, 2002).

A partir da década de 80, a soja começou a se expandir para o cerrado. Inicialmente, essa cultura não penetrou de forma significativa; os cerca de $15 \%$ da área cultivada com soja fora da região Sul e de São Paulo incluíam o sul de Mato Grosso do Sul, o sul de Goiás e a região do Triângulo Mineiro.

Estimulada por programas de desenvolvimento do governo do estado de Minas Gerais, a soja já havia atingido os cerrados do Triângulo Mineiro e do oeste do estado. Ainda de forma incipiente, a lavoura havia alcançado também zonas de cerrado no centro e no norte de Mato Grosso do Sul e no sudeste de Mato Grosso (Mueller, 2002).

Em 1990, as áreas de concentração de soja já formavam um contínuo bastante expressivo na parte central do país, associado, em grande medida, à expansão da lavoura no cerrado. Mato Grosso já era o terceiro maior produtor no Brasil, com cerca de 1,6 milhões de hectares plantados.

Em 2009, a lavoura já tinha expressão em quase todo o estado, à exceção da região do pantanal, na faixa oeste. Essa expansão foi fortemente influenciada pelas condições naturais antes consideradas inóspitas, pelos investimentos em tecnologia, como melhoramento genético, e em infra-estrutura. Isso levou a uma maior competitividade da soja do Centro-oeste, mesmo com um maior custo de transporte (Bermann, 2007).

A tabela 3.1 apresenta os dados da evolução da produção, área plantada e produtividade da soja no Brasil, no período de 1990 a 2006. 
Tabela 3.1 - Evolução da produção, área plantada e produtividade da soja no Brasil - 1990 a 2006.

\begin{tabular}{|c|c|c|c|}
\hline Safra & $\begin{array}{c}\text { Produção } \\
\text { (milhões t) }\end{array}$ & $\begin{array}{c}\text { Arrea Plantada } \\
\text { (milhões ha) }\end{array}$ & $\begin{array}{c}\text { Produtividade } \\
\text { (kg/ha) }\end{array}$ \\
\hline $1990 / 91$ & 15,39 & 9,7 & 1.580 \\
\hline $1995 / 96$ & 23,19 & 10,7 & 2.175 \\
\hline $2000 / 01$ & 38,43 & 14,0 & 2.751 \\
\hline $2003 / 04$ & 49,79 & 21,4 & 2.329 \\
\hline $2005 / 06$ & 55,03 & 22,7 & 2.419 \\
\hline $2007 / 08$ & 60,02 & 21,3 & 2.816 \\
\hline $2008 / 09$ & 57,63 & 21,56 & 2.674 \\
\hline
\end{tabular}

Fonte: MAPA, 2009.

Observa-se um aumento de produção e da área plantada de soja no Brasil. A produção passou de 15,39 milhões de toneladas em 1990/91 para 53,43 milhões de toneladas em 2006/07, com maior acréscimo entre 2001/02 e 2003/04, quando a produção aumentou 10,1 milhões de toneladas, o que corresponde a um acréscimo de 19,42\% em relação à safra anterior.

Em relação à área plantada, observa-se um aumento de 9,7 milhões de hectares em 1990/91 para 22,2 milhões de hectares em 2005/06, devido principalmente à maior produção constatada no mesmo período. O maior crescimento se deu entre 2001/02 e 2004/05, com acréscimo de 6,7 milhões de hectares de área plantada no Brasil.

Em 2003 e 2004, o Brasil se configurou como o maior exportador mundial de soja, representando cerca de $8 \%$ das exportações do país. Os estados do Paraná, Mato Grosso e Mato Grosso do Sul são os principais produtores de soja do país, sendo o estado do Mato Grosso o maior produtor de soja do país, responsável por $27 \%$ da produção nacional, de acordo com dados de 2007 do Ministério da Agricultura, Pecuária e Abastecimento (MAPA).

A soja já chegou moderna ao Brasil, mas o crescente emprego de tecnologia e o desenvolvimento de variedades adaptadas a diferentes ecossistemas do país, principalmente pela Embrapa e empresas de sementes do setor privado, permitiram um aumento continuado do rendimento da lavoura.

Abaixo, a Figura 3.1 mostra as principais áreas de produção de soja no Brasil onde é possível observar a concentração na região sul, nos estados do Paraná, Santa Catarina e Rio 
Grande do Sul e nas áreas centrais do país, nos estados de Minas Gerais, Goiás, Mato Grosso e Mato Grosso do Sul com tendências a expansão no sentido norte do país.

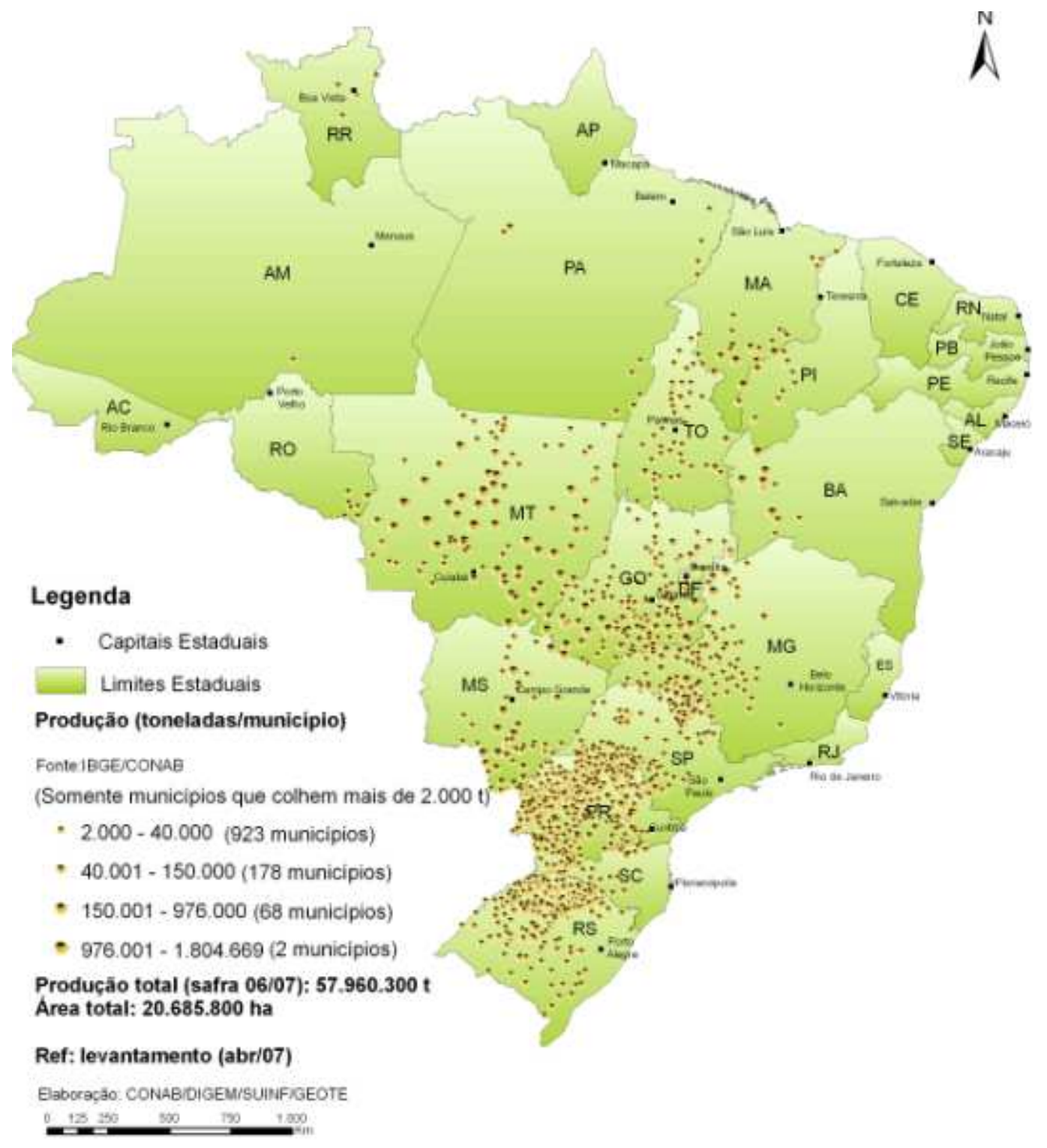

Fonte: CONAB, 2008

Figura 3.1 - Produção de Soja no Brasil

Ao analisar a distribuição da produção de soja por região, de acordo com dados do MAPA (2007), observa-se que em 1990/91 a região Sul representava 40\% da produção do país, com expressividade nos estados do Paraná (23\%), maior estado produtor, e Rio Grande do Sul (15\%). A região Centro-Oeste representava 43\%, e os estados com maior representatividade eram Mato Grosso (17\%) e Mato Grosso do Sul (15\%), sendo Goiás o 
quinto maior estado produtor, com $11 \%$, ocupando áreas de cerrado especialmente no leste do seu território. Quanto às demais regiões, a Sudeste representava 13\%, a Nordeste $4 \%$ e a região Norte não tinha expressividade na produção.

Mesmo possuindo as maiores áreas ocupadas com cultura de soja (57\%), a região Sul apresentava a menor produtividade do país, cerca de 1.100 quilos por hectare. A maior produtividade apresentava-se no Centro-Oeste, com mais de 2.200 quilos por hectare, mesmo sendo uma área consideravelmente de menor ocupação com cultivo de soja (30\%). As regiões Nordeste e Sudeste, aparecem em seguida com uma produtividade de cerca de 2.000 quilos por hectare, ultrapassando até mesmo os níveis de produtividade da região Sul.(Bermann, 2007).

Em 2000/01, a produção de soja aumentou em todas as regiões, menos na Sudeste, que apresentou $7 \%$ da produção (um decréscimo de 5\%). Por sua vez, a região Norte começou a aparecer, representando $1 \%$ da área produtora total. A região Centro-Oeste representava 45\%, com grande expressividade de Mato Grosso, onde a produção passou de $17 \%$ para $25 \%$ (um acréscimo de $8 \%$ ), enquanto os estados de Mato Grosso do Sul e Goiás apresentaram, respectivamente, área produtora de 8\% e 11\%. (Mapa, 2007)

A região Sul manteve-se como segunda área produtora, com representatividade de 42\% (um acréscimo de $2 \%$ em relação à 1990/91), com expressividade do Paraná, com $22 \%$ da produção, e Rio Grande do Sul, com 19\% da produção. (Mapa, 2007)

O Paraná perdeu a primeira posição como estado produtor, que passou a ser ocupada por Mato Grosso. Nessa mesma safra houve decréscimo da participação da região Sul na área total cultivada, passando a $43 \%$, enquanto a participação da região CentroOeste aumentou para $41 \%$.

A produtividade da região Sul aumentou para 2.718 quilos por hectare, representando a segunda região com maior produtividade, atrás apenas do Centro-Oeste, que também aumentou sua produtividade para 2.952 quilos por hectare. As outras regiões também tiveram aumento de produtividade, mas não chegaram a 2.500 quilos por hectare. (Mapa, 2007)

Em 2006/07, a região Centro-Oeste disparou como maior área produtora (47\% da produção no Brasil), com destaque para Mato Grosso, que mais uma vez aumentou a produção para $27 \%$ e permaneceu como o maior estado produtor. A região Sul diminuiu sua expressividade para $37 \%$ da produção brasileira; destacaram-se os estados do Paraná 
(21\%) e Rio Grande do Sul (14\%). A região Sudeste manteve sua produção, representando $7 \%$, e as regiões Nordeste e Norte aumentaram para $7 \%$ e $2 \%$, respectivamente.

O gráfico 3.1 ilustra a produção da soja na safra 2006/07:

\section{Gráfico 3.1 - Distribuição da produção da soja por estado. Safra 2006/2007}

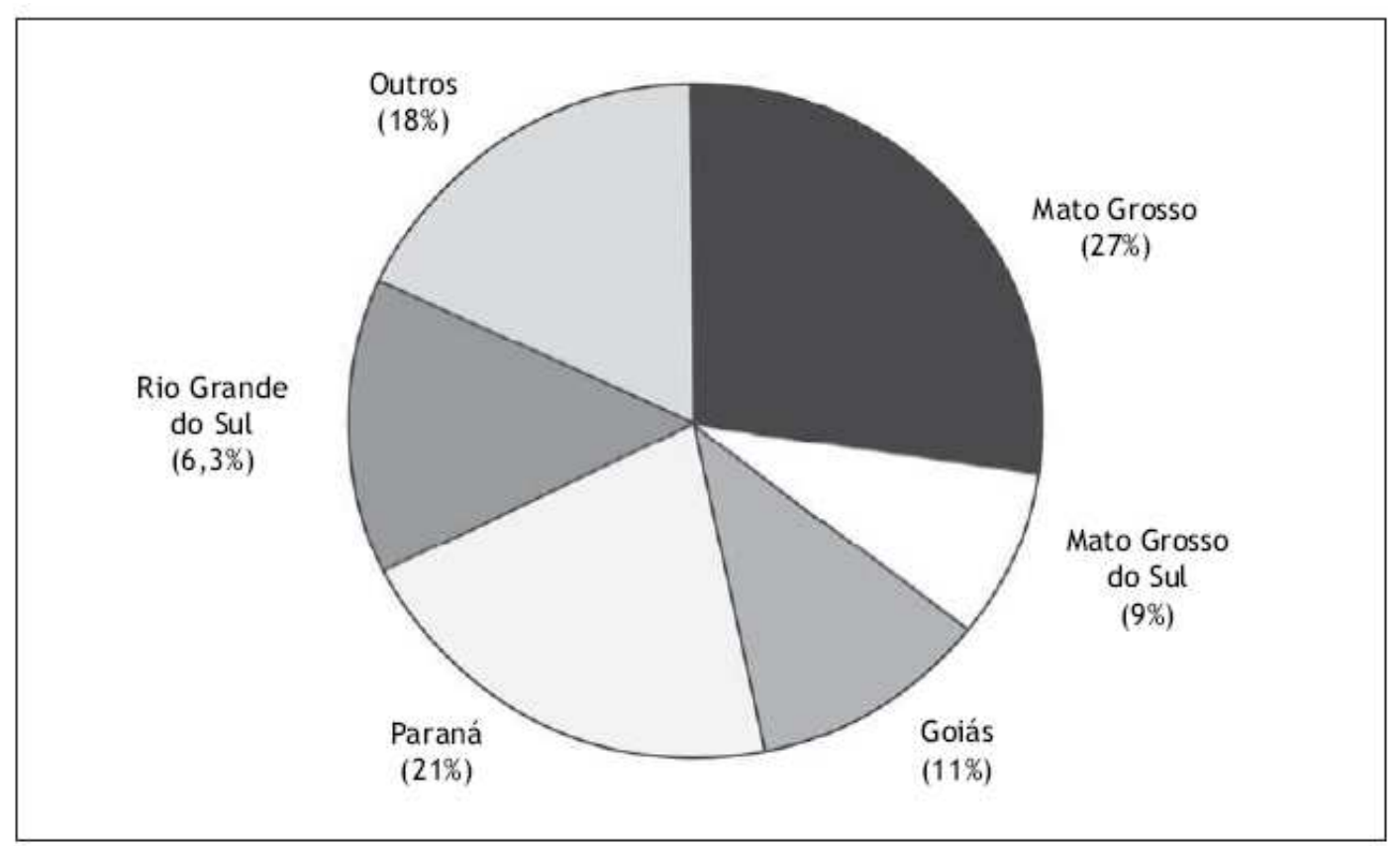

Fonte: MAPA, 2007

A área plantada de soja aumentou na região Centro-Oeste para 44\%, um acréscimo de 3\% em relação aos anos de 2000/01, e a região Sul teve um decréscimo de 3\%, representando $40 \%$ da área total no país. As outras regiões continuaram a concentrar menos de $20 \%$ da área total plantada. (Mapa, 2007)

Dados recentes demonstram que o estado de Mato Grosso apresenta cerca de 6,1 milhões de hectares cultivados com soja (MAPA, 2007), o que o transformou no maior produtor brasileiro desse produto, superando o Paraná.

Esse rápido crescimento e o espetacular avanço territorial da soja foram induzidos e favorecidos pelo desenvolvimento tecnológico da pesquisa agropecuária brasileira, que adaptou a cultura da soja às condições do meio tropical (Arvor et al., 2007).

Muitos fatores contribuíram para que a soja se estabelecesse como uma importante cultura, primeiro no sul do Brasil (anos 60 e 70) e, posteriormente, nos Cerrados do Brasil Central (anos 80 e 90). Com relação à região central do Brasil, considerada a nova e 
principal fronteira da soja, podemos destacar as seguintes causas para explicar o espetacular crescimento da sua produção: (Embrapa, 2004).

* construção de Brasília na região, determinando uma série de melhorias na infraestrutura regional, principalmente vias de acesso, comunicações e urbanização;

* incentivos fiscais disponibilizados para a abertura de novas áreas de produção agrícola, assim como para a aquisição de máquinas e construção de silos e armazéns;

* estabelecimento de agroindústrias na região, estimuladas pelos mesmos incentivos fiscais disponibilizados para a ampliação da fronteira agrícola;

* baixo valor da terra na região, comparado ao da Região Sul, nas décadas de 1960/70/80;

* desenvolvimento de um bem sucedido pacote tecnológico para a produção de soja na região, com destaque para os novos cultivos adaptados à condição de baixa latitude da região;

* topografia altamente favorável à mecanização, favorecendo o uso de máquinas e equipamentos de grande porte, o que propicia economia de mão de obra e maior rendimento nas operações de preparo do solo, tratos culturais e colheita;

* boas condições físicas dos solos da região, facilitando as operações da maquinaria agrícola e compensando, parcialmente, as desfavoráveis características químicas desses solos;

* melhorias no sistema de transporte da produção regional, com o estabelecimento de corredores de exportação, utilizando articuladamente rodovias, ferrovias e hidrovias;

* bom nível econômico e tecnológico dos produtores de soja da região, oriundos, em sua maioria, da Região Sul, onde cultivavam soja com sucesso previamente à sua fixação na região tropical; e

* regime pluviométrico da região altamente favorável aos cultivos de verão, em contraste com os freqüentes veranicos ocorrentes na Região Sul, destacadamente no RS.

* mercado internacional em alta, principalmente em meados dos anos 70, em resposta à frustração da safra de grãos na Rússia e China, assim como da pesca da anchova no Peru, cuja farinha era amplamente utilizada como componente protéico na fabricação de rações para animais, para o que os fabricantes do produto passaram a utilizar-se do farelo de soja;

* substituição das gorduras animais (banha e manteiga) por óleos vegetais, mais saudáveis ao consumo humano; 
* facilidades de mecanização total da cultura;

* surgimento de um sistema cooperativista dinâmico e eficiente, que apoiou fortemente a produção, a industrialização e a comercialização das safras;

* melhorias nos sistemas viário, portuário e de comunicações, facilitando e agilizando o transporte e as exportações.

O gráfico 3.2 ilustra a evolução da produtividade da soja nas regiões do Brasil. Observa-se que sempre houve uma evolução crescente da produtividade de soja no Brasil, com destaque para a região Centro-Oeste, que atingiu, na safra 2006/07, a produtividade de 2.941 quilos por hectare.

\section{Gráfico 3.2 - Evolução da Produtividade da soja em regiões do Brasil em anos selecionados}

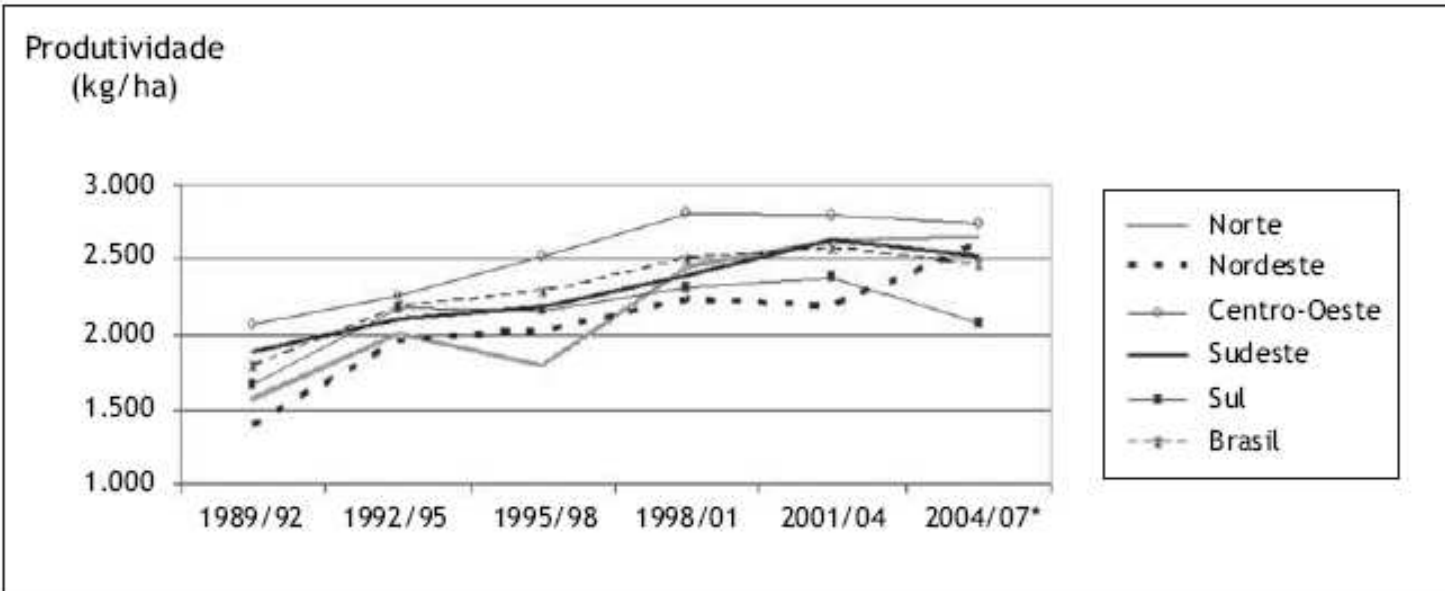

Fonte: MAPA, 2007

Ressalta-se os saldos positivos dessa região, que nas safras de 1990/91 obteve 2.263 quilos por hectare. A produtividade também aumentou, no período citado, principalmente devido às melhores técnicas empregadas no plantio, como sementes modificadas, mecanização da agricultura, uso de fertilizantes e agricultura de alta precisão, com um aumento de 1.580 quilos por hectare em 1990/91 para 2.736 quilos por hectare em 2006/07.

Entre 2004/05 e 2006/07, houve um aumento considerável na produtividade, de 528 quilos por hectare. Ressalta-se o desempenho recente do Centro-Oeste, que concentra boa parte da produção de soja no bioma cerrado. A média para a região na safra de 2000/01 foi de 2.845 quilos por hectare, bem acima da média nacional; nessa safra, o rendimento de 
Mato Grosso (3.050 quilos por hectare) foi o mais alto do país, fato que vem se repetindo nos últimos anos (Mapa, 2007).

Porém, em 2003/04 foram registradas as menores produtividades no país, com índices entre 2.100 e 2.700 quilos por hectare. A região Sul teve o maior crescimento percentual, já que em 1990/91 tinha produtividade de 1.224 quilos por hectare e alcançou, atualmente, 2.530 quilos por hectare.

Tomando o conjunto das regiões, observa-se que há uma tendência a uma relativa homogeneização dos comportamentos regionais quanto à produtividade da soja. A Tabela 3.2 apresenta as áreas potenciais para expansão agrícola de acordo com as estimativas do BNDES:

Tabela 3.2 - Potencial para expansão agrícola

\begin{tabular}{|l|c|}
\hline \multirow{2}{*}{ Área Total do Brasil } & Em MM por hectare \\
\cline { 2 - 2 } & 855 \\
\hline Áreas com Restrição Ambiental & 418 \\
\hline Áreas Urbanizadas & 3 \\
\hline Área Agriculturável & 435 \\
\hline Área de Produção de Grãos & 46 \\
\hline Área Total de Pecuária & 180 \\
\hline Áreas de Pastagens Cultivadas & 90 \\
\hline Área Disponível & 299 \\
\hline Área com Potencial Agrícola & 68 \\
\hline
\end{tabular}

Fonte: BNDES, $2007^{8}$

Na verdade, a adoção de tecnologia para elevar a produtividade e reduzir os custos vem sendo essencial para contrapor o elevado custo de transporte da soja nas zonas novas do cerrado (Mueller, 2002). A agricultura de precisão, que calcula a produtividade por metros quadrados, facilita a inserção de fertilizantes e nutrientes nas áreas em que se faz necessário para o aumento da produtividade.

\footnotetext{
${ }^{8}$ Apresentação realizada pelo BNDES no Seminário: Agrocombustíveis e Agricultura Familiar e Camponesa, no Rio de Janeiro em julho de 2007.
} 
Entretanto, a inserção de fertilizantes, a mecanização da produção, o uso de sementes modificadas geneticamente causa impactos no solo. Assim sendo, a soja tem se expandido para as áreas da Floresta Amazônica, como pode ser observado na Figura 3.2.

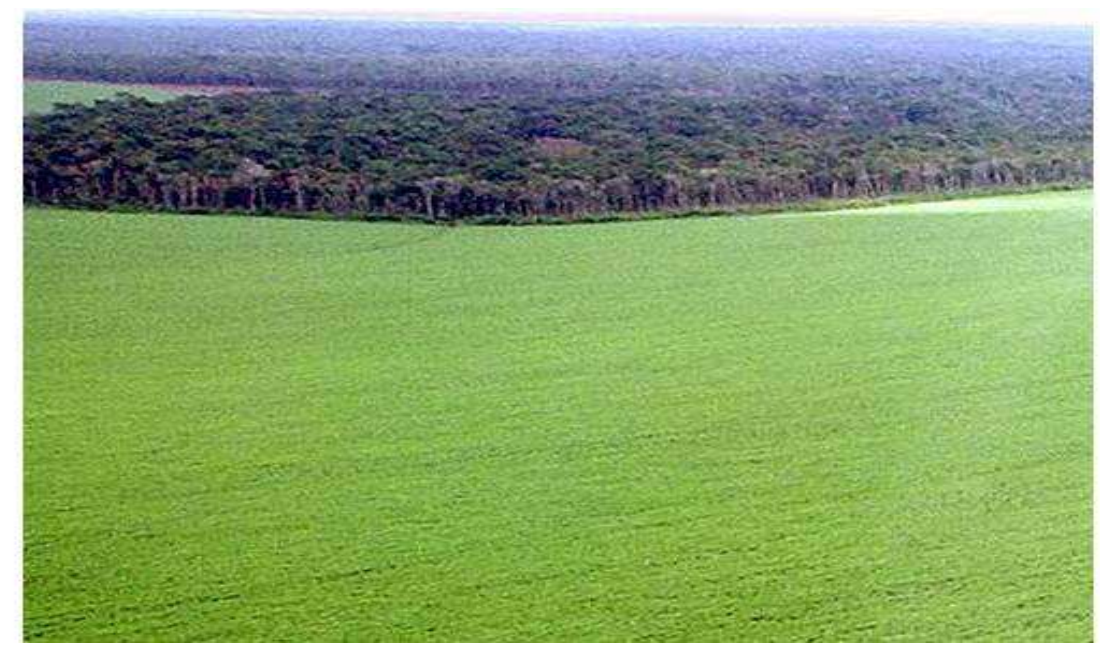

Fonte: http://www.socioambiental.org/esp/soja.br

Figura 3.2: Soja ao lado da Floresta Amazônica

E, com a expansão da fronteira agrícola para as áreas de florestas os impactos podem ser irreversíveis, como veremos no Capítulo 3.2 adiante. 


\subsection{Estrutura Produtiva da Soja}

Em função da atividade sojeira, foram geradas aberturas de fronteiras, fundando cidades no interior do país, transformando os pequenos conglomerados urbanos em centros maiores. Esse processo, determinou uma cadeia de mudanças sem precedentes na história do país.

Foi a soja, inicialmente auxiliada pelo trigo, responsável pela implementação da agricultura comercial no Brasil. Apoiou a aceleração da mecanização das lavouras brasileiras, a modernização do sistema de transportes, a expansão da fronteira agrícola, o incremento do comércio internacional e a aceleração da urbanização do país.

De certa forma, a cultura da soja interiorizou parte população brasileira (concentrada no sul, sudeste e litoral do Norte e Nordeste) e ajudou na tecnificação de outras culturas (destacadamente a do milho). De qualquer forma, a soja interiorizou a agroindústria nacional e expandiu da avicultura e da suinocultura brasileiras.

Entretanto, a organização não-governamental Greenpeace Brasil verificou que, a partir de 2004, a indústria da soja surgiu como um novo ator nas fronteiras de destruição da floresta. Ainda, identificou quatro multinacionais na área: Archer Daniels Midland (ADM), Bunge, Dreyfus e Cargill. Essas empresas formam quase um monopólio na prensagem de soja na Europa, fornecendo matéria-prima para a indústria de ração animal.

Elas estão agindo no setor no fornecimento de quase toda a cadeia produtiva, desde sementes e agrotóxicos à construção de infra-estrutura, como portos e armazéns, sem favorecer o desenvolvimento regional. Juntas, financiam cerca de $60 \%$ da produção de soja brasileira.

Grupos brasileiros, como o Grupo André Maggi, também são atores fortes no setor. Como governador de Mato Grosso, Blairo Maggi, líder do Grupo André Maggi, que estabeleceu a meta de duplicar a produção agrícola do estado em dez anos. Outros atores financeiros internacionais também têm importante papel no financiamento da plantação.

Segundo o artigo "Que fim levaram os fazendeiros?” (2000), elaborado por Brian Halweil, as já citadas empresas transnacionais que controlam a produção de soja no Brasil são os maiores processadores e comerciantes de soja ao longo do rio Mississipi, nos EUA, e dos rios Paraguai e Paraná, no Brasil. O primeiro é a principal via de escoamento da soja americana para os mercados mundiais, e os segundos fluem pelo centro da emergente região de soja no Brasil. 
Essas empresas de commodities fazem lobby junto aos estados em prol da expansão da infra-estrutura ao longo dos rios, argumentando que isso aumentaria a competitividade dos fazendeiros no mercado global. No entanto, essa situação aumenta o confronto entre fazendeiros brasileiros e americanos, acabando numa corrida onerosa para maximizar a produção, provocando práticas que essencialmente degradarão seus solos e lançarão às favas os investimentos de longo prazo.

$\mathrm{Na}$ prática, as empresas que realizam o processamento, transporte e comércio dos grãos é que saem beneficiadas. $\mathrm{O}$ autor revela que, como conseqüência do aumento da competição entre os fazendeiros pelo mercado global, os preços da soja se deprimem, diminuindo a margem de lucro, acabando por gerar menos receita por tonelada produzida. Dessa forma, os fazendeiros serão engolidos pelas grandes fazendas corporativas, que podem compensar as margens menores por tonelada produzindo volumes maiores.

Halweil (2000) mostra também que o processo de industrialização da agricultura mundial levou à diminuição da margem dos fazendeiros e ao incremento do lucro das empresas de insumo e comercialização. Assim, surgiram vários grupos de empresas que, por meio de fusões, aquisições e alianças com outros elos da cadeia alimentícia, possuem hoje um controle inconsútil e totalmente verticalizado da rede alimentícia, desde o gene até a prateleira do supermercado.

Observa-se o deslocamento de populações para as cidades, devido à introdução da monocultura da soja por meio da mecanização, uso de fertilizantes e sementes melhoradas geneticamente, além da expansão de grandes propriedades de terra.

As grandes empresas ocupam espaços no campo antes ocupado por culturas diversificadas e familiares, reduzindo o emprego, a capacidade de produção de alimentos tradicionais e comprometendo a segurança alimentar da população. Esse processo tem levado ao aumento do deslocamento de pequenos colonos, em razão de conflitos sociais ou da compra de lotes, com a conseqüente expulsão dos colonos. 


\subsection{Impactos da cultura sojeira}

Os sistemas monocultores, como a soja, foram viabilizados graças aos avanços do setor industrial agrícola e das pesquisas nas áreas de química, mecânica e genética. Este pacote tecnológico data do início da década de 1970 e ficou conhecido como "Revolução Verde" ${ }^{\text {. }}$. Este advento levava a crer que o aumento da produção e produtividade agrícola proporcionado por ele solucionaria a questão da fome no mundo.

Na Índia, a "Revolução Verde" permitiu um aumento na produção agrícola mais veloz que o crescimento populacional, com as exportações cobrindo as importações e a tornando auto-suficiente. Entretanto a disponibilidade de alimentos continuava medíocre e a sua distribuição continuava sendo tão desigual quanto antes (Veiga, 1993).

De acordo com Leonel (1998), na década de 1980 a "Revolução Verde" duplicou a produtividade por hectare de alguns grãos e aumentou a área cultivada em 24\%, mas:

“(...)ao custo de um notável incremento de energia comercial, mediante insumos de toda ordem: máquinas, combustíveis, fertilizantes, pesticidas herbicidas, irrigação, eletricidade e transporte" (Batista, 1994 ).

Mueller (1995) questiona a sustentabilidade das tecnologias advindas da "Revolução Verde" e cita os impactos provocados por esta nos cerrados:

a) compactação e impermeabilização dos solos pelo uso intensivo de máquinas agrícolas;

b) erosão;

c) contaminação por agrotóxicos nas águas, alimentos e animais;

d) impactos danosos da retirada da vegetação nativa de áreas contínuas extensas;

e) assoreamento de rios e reservatórios;

\footnotetext{
${ }^{9}$ Revolução verde refere-se à invenção e disseminação de novas sementes e práticas agrícolas que permitiram um vasto aumento na produção agrícola em países menos desenvolvidos durante as décadas de 60 e 70 . O modelo se baseia na intensiva utilização de sementes melhoradas (particularmente sementes híbridas), insumos industriais (fertilizantes e agrotóxicos), mecanização e diminuição do custo de manejo. Também são creditados à revolução verde o uso extensivo de tecnologia no plantio, na irrigação e na colheita, assim como na gerenciamento de produção. A introdução destas técnicas em países menos desenvolvidos provocou um aumento brutal na produção agrícola de países não-industrializados. Países como o Brasil e a Índia foram alguns dos principais beneficiados na produção, mas também mais prejudicados ambientalmente e culturalmente, pois muitas técnicas agrícolas que harmonizavam com a produção de alimentos, foi tratada como "atraso", e em busca da modernidade, efetuou-se um caso clássico de modernização conservadora, onde, em benefício de poucos se destruiu o patrimônio de todos.
} 
f) aparecimento de novas pragas ou aumento das já conhecidas;

g) risco à sobrevivência de espécies vegetais e animais com a perda de habitat natural devido a expansão agrícola (Cunha, 1994).

A perda de solo por quilo de grão de soja produzido pode chegar a 10 quilos (Novaes, 2000). Outros impactos causados por longos períodos de exploração agrícola pesada, mecanizada e tecnologicamente inadequada nos ecossistemas do extremo sul, da região dos pinheirais e dos cerrados são apontados no estudo realizado pelo Ministério do Meio Ambiente, são eles: desmatamento e degradação dos solos (erosão e em alguns casos desertificação) e quadro crítico quanto à disponibilidade de recursos hídricos devido à irrigação.

Diante um quadro extenso de impactos advindos da cultura da soja, os capítulos 3.3.1 e 3.3.2 pretendem tratar de alterações significativas em alguns ambientes específicos, como nas águas, nos solos e na biodiversidade, no clima.

\subsubsection{Nas águas e no solo}

Quando se substituem as pastagens por lavouras de soja, o quadro de impactos se altera substancialmente. Há problemas significativos que se referem ao uso da água como: alterações na qualidade da água dos rios, a eliminação da mata ciliar, que protege as margens dos rios da erosão podendo ocasionar perda de ecossistemas como as florestas e os cerrados e um processo intenso de assoreamento de muitos córregos e nascentes.

A presença de agrotóxicos na água é de difícil verificação, porém já fora observado que nas áreas do rio Xingu, por exemplo.Houve uma diminuição no número de peixes dos rios e que a água tem sofrido alterações, como ficar turva em alguns pontos, o que está associado ao assoreamento de cursos d'água.

A contaminação da água por agrotóxicos pode ocorrer de duas formas: através do lençol freático ou pelo escoamento superficial da água. No Cerrado, onde predominam as areias quartzozas, que são altamente suscetíveis à erosão e à lixiviação, a chuva carrega as camadas mais superficiais do solo, e com elas os resíduos químicos, diretamente para dentro dos rios.

Já nas áreas de floresta de transição, onde predominam os solos do tipo latossolo vermelho-amarelo - que são muito ácidos, profundos e de boa drenagem - a chuva leva os 
agrotóxicos para dentro do solo, onde ficam acumulados nas águas subterrâneas do lençol freático.

É importante ter cautela no plantio para que o manejo não ocorra de modo predatório dos recursos naturais e desmatamento de vastas áreas, pois os impactos sobre os rios não passaram despercebidos aos produtores como o assoreamento, a escassez e a mudança da qualidade da água. Por isso, a nova geração de sojicultores tem deixado a mata nas beiras dos rios se regenerarem.

A utilização agrícola de algumas terras da floresta revela-se um fracasso devido à deficiência na distribuição de nutrientes e solos ácidos dessas florestas. No entanto, muitos projetos comerciais agrícolas são ainda realizados em florestas tropicais, embora muitos destes reverter para pastagem, após o esgotamento dos solos. Algumas regiões, como aquelas da baixa Amazônia (várzea), são mais adequadas para a agricultura comercial porque as inundações anuais reconstituirão a reserva de nutrientes.

Em relação ás perdas de solo, o Instituto Agronômico de Campinas (IAC, 1997) estima que cada hectare cultivado no país perde, em média, 25 toneladas de solo, o que significa uma perda anual de cerca de um bilhão de toneladas ou, aproximadamente, um centímetro da camada superficial do solo.

Mesmo com o atual sistema de plantio direto (sem aração) há perda de solo, ainda que seja menor que no sistema tradicional de grade - com aração. Segundo o estudo "Uso de instrumentos econômicos para defesa do Bioma Cerrado”, de Maurício Gallinkin (2008), o plantio direto causa perdas de cerca de $40 \%$ menores em relação ao sistema de aragem.

Além disso, no sistema de monocultura exige a aplicação de maiores quantidades de insumos agrícolas para manter a fertilidade do solo. Pesquisa do IAC de 1997 mostra que cerca de 10 milhões de toneladas de fertilizantes foram utilizados nos 40 milhões de hectares cultivados com grãos no país. Considerando que a aplicação desses insumos se dá principalmente sobre as camadas superficiais do solo, a erosão acarreta também perdas de fertilizantes, o que pode levar à contaminação de águas superficiais.

A Figura 3.3 mostra a utilização de trator na preparação do solo para plantio. 


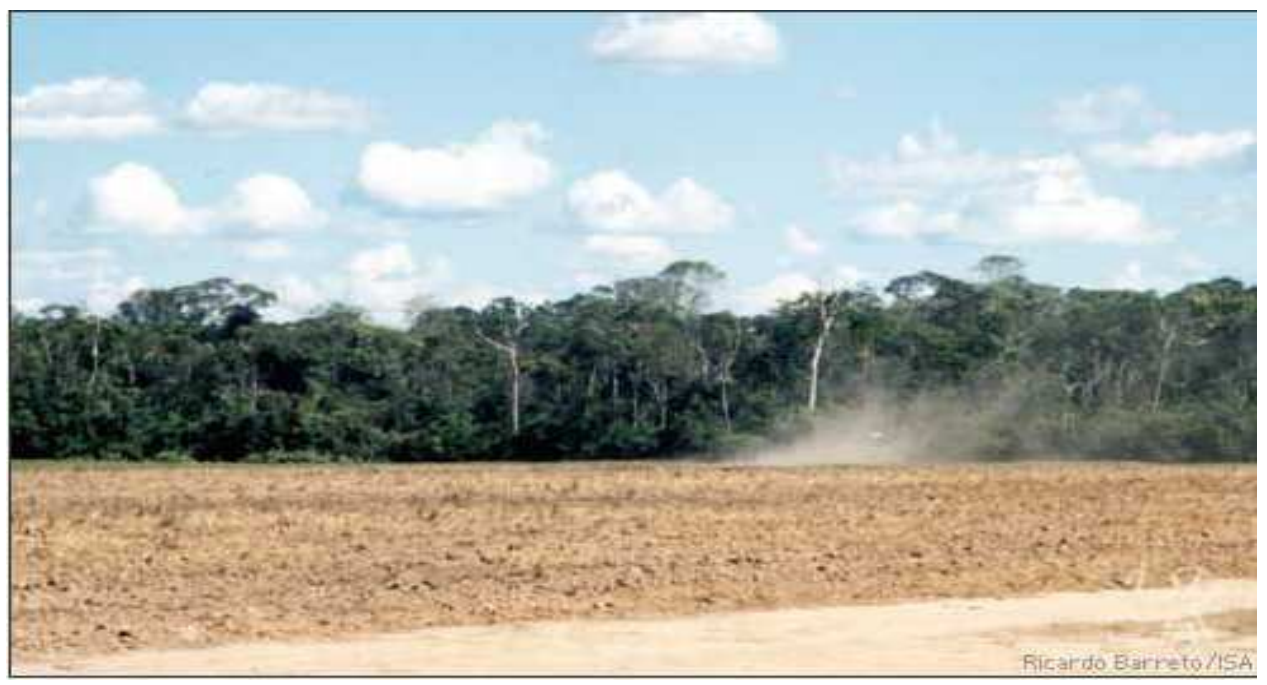

Fonte: http://www.socioambiental.org/esp/soja.br

Figura 3.3: Trator encoberto pela poeira preparando o plantio, com floresta remanescente ao fundo em Canarana - MT.

\subsubsection{Na biodiversidade e no clima}

Outro impacto desse sistema de cultivo é a perda de diversidade biológica e a ruptura do equilíbrio natural existente entre a vegetação nativa e o solo, visto que exige desmatamentos em larga escala.

Segundo estudo apresentado por Assad (2008), em seu artigo "Conservação de Solos e Biodiversidade", que integra a publicação do ISA "Seria Melhor mandar ladrilhar?", nas condições do clima tropical, são necessárias centenas de anos para a formação de um centímetro de solo bem estruturado. Assad explica que :

"Os processos erosivos que ocorrem nos solos são tanto mais intensos quanto maior for a ruptura entre o equilíbrio existente no ambiente, em particular entre solos e organismos que evoluíram a partir de relações independentes."

As atividades antrópicas, portanto, quando realizadas nessa amplitude e em um curto espaço de tempo exercem grande impacto sobre o ambiente, pois acontecem em velocidade muito maior do que os processos evolutivos dos organismos e de formação dos solos, que são bastante lentos.

Impacto difícil de mensurar é a perda de biodiversidade. A origem de toda biodiversidade está associada à história geológica e à evolução dos diferentes relevos que, ao longo de milhares de anos, propiciaram condições especiais para o desenvolvimento de 
uma paisagem dominada pelas florestas. O Instituto Brasileiro do Meio Ambiente e dos Recursos Naturais Renováveis (Ibama) estima que exista no Cerrado mais de 10 mil espécies de plantas, sendo 4.400 endêmicas.

As características físicas e bióticas fazem dessa região uma das áreas prioritárias para a conservação A partir daí podemos buscar alternativas que explorem de maneira sustentável as potencialidades dos recursos naturais da região e seus serviços ambientais.

Os cerrados, que correspondem a $23 \%$ da superfície do Brasil, dominavam as áreas ao sul do Parque Indígena do Xingu e abrangiam cerca de um terço de toda a região das nascentes do Rio Xingu. Porém, o que se constata hoje é que destes $23 \%$, mais de $30 \%$ desapareceram e cerca de $60 \%$ está antropizado em diferentes graus, segundo dados do Ministério do Meio Ambiente.

Já nas áreas de floresta, existem evidências de que essa atividade antrópica exerce pressão sobre o clima da região. No estudo de Fisch (2006), afirma-se que:

"A substituição da cobertura vegetal de floresta por pastagens modifica as interações entre o sistema solo-planta-atmosfera, com a conseqüente alteração no microclima local”.

Como exemplo, ele revela que dados de sua pesquisa observados durante dez anos na Amazônia mostraram que a ocorrência de chuvas em Rondônia é 28\% superior na área de floresta tropical do que o existente em áreas abertas para pastagens.

Os sojicultores da região são bons termômetros. Segundo eles, é possível identificar variações na ocorrência de chuvas de uma safra para outra, como, por exemplo, no período 2002/2003, cuja estação seca prolongada atrasou o plantio. Já no momento da colheita, houve chuva em demasia. Como resultado, algumas fazendas chegaram a perder até $30 \%$ da safra prevista.

Provavelmente por não existirem pesquisas mostrando a relação entre a alteração do regime de chuvas e as atividades antrópicas no Mato Grosso, os produtores da região não acreditam que o nível de desmatamento tenha relação com as mudanças no regime de chuvas e em outros aspectos climáticos da região.

O estudo de Fish (2006) aborda as atividades antrópicas na Amazônia, que revelam sua influência no clima em escala macro. Segundo o cientista, resultados de simulações numéricas a partir dos Modelos de Circulação Geral da Atmosfera mostram que caso houvesse um "desmatamento completo e imediato" da Amazônia, haveria um aumento da temperatura do ar próximo à superfície na ordem de $0,6^{\circ}$ a $2^{\circ} \mathrm{C}$, uma redução no total de 
precipitação e evaporação (de 20 a 30\% do que acontece normalmente na floresta) e uma estação seca mais prolongada.

Atualmente, a temperatura do planeta vem subindo um décimo de grau por década ou um grau por século, o que é considerado gravíssimo pelos especialistas em mudanças climáticas. 


\subsection{A Participação da soja no PNPB}

O principal uso da soja se dá para a indústria alimentícia. É um grão rico em proteínas, cultivado como alimento tanto para humanos quanto para animais. Além da margarina e do óleo, a soja está presente em cerca de $60 \%$ dos alimentos vendidos nos supermercados. Entra na formulação de pães, bolos, bolachas, massas, sorvetes, chocolates e até alimentos infantis, entre outros.

Também, seu componente, a lecitina de soja é útil na indústria química como matéria-prima para fabricação de tintas e inseticidas, e na indústria farmacêutica, na fabricação de anticoncepcionais. Seus principais produtos definem-se por meio do grão, farelo e óleo de soja. Outros produtos derivados da soja incluem farinha, sabão, cosméticos, resinas, solventes e agora como alternativa para produção de biocombustíveis.

Apesar de adição de biodiesel ao combustível comum, praticada no país desde janeiro de 2008, ajudou o Brasil a reduzir sua dependência do diesel mineral importado, mas ainda não conseguiu cumprir uma de suas principais metas: diversificar a matriz energética nacional para a produção de combustível limpo.

A soja ainda é o carro-chefe. O grão foi base para a produção de 949 milhões de litros de biodiesel no ano de 2008, o equivalente a $81 \%$ dos 1,17 bilhão de litros de B100 fabricados no país. A participação da soja na matriz energética dos biocombustíveis vem caindo, mas o ritmo da diversificação ainda está abaixo do desejado (ANP, 2008).

A produção da soja para óleos vegetais é um mercado secundário, ela está direcionada ao mercado alimentício. 80\% como farelo para produção de ração animal, 19\% aproveitado como óleo para alimento e energia e $1 \%$ representa a perda na produção. Apesar disso, como há grande exportação de soja no Brasil, seu óleo é matéria-prima para biodiesel no exterior (Brien, 2009)

Em janeiro de 2008, o porcentual chegava a 90\%. Na época, ainda vigorava o B2, adição obrigatória de $2 \%$ de diesel vegetal ao combustível fóssil. A mistura foi incrementada para 3\% na metade de 2008 e, em 2009, o programa entrou em uma nova fase. Desde o início do julho, todo o combustível vendido nas bombas dos postos de gasolina do país precisa, obrigatoriamente, conter $4 \%$ de biodiesel.

Todos esses números mostram que o cronograma do PNPB vem sendo cumprido, que o país já avançou muito nesta área e que os benefícios trazidos pelo programa são inegáveis. Mas, por outro lado, indicam também que, apesar de todos os esforços do 
governo e do setor produtivo, a viabilidade do biodiesel ainda depende da soja, mesmo sendo a cultura com menos teor oleaginoso, como visto na tabela 3.3, que identifica a potencialidade de algumas oleaginosas para produção de biodiesel:

Tabela 3.3 - Características de alguns vegetais com potencial para produção de biodiesel

\begin{tabular}{ccccc}
\hline Espécie & $\begin{array}{c}\text { Origem do } \\
\text { óleo }\end{array}$ & $\begin{array}{c}\text { Conteúdo de } \\
\text { óleo }(\%)\end{array}$ & $\begin{array}{c}\text { Meses de } \\
\text { colheita }\end{array}$ & $\begin{array}{c}\text { Rendimento em } \\
\text { óleo (t/ha) }\end{array}$ \\
\hline Dendê (Elaeis guineensis N.) & Polpa & 26 & 12 & $3,0-6,0$ \\
Babaçu (Attalea speciosa M.) & Amêndoa & 66 & 12 & $0,4-0,8$ \\
Girassol (Heleianthus annus) & Grão & $38-48$ & 3 & $0,5-1,5$ \\
Canola (Brassica camprestris) & Grão & $40-48$ & 3 & $0,5-0,9$ \\
Mamona (Ricinus Communis) & Grão & $43-45$ & 3 & $0,5-1,0$ \\
Amendoim (Arachis ipogaea) & Grão & $40-50$ & 3 & $0,6-0,8$ \\
Soja (Glycine max) & Grão & 17 & 3 & $0,2-0,6$ \\
\hline
\end{tabular}

Fonte: Macedo; Nogueira, 2005.

Como demonstrado na tabela, o conteúdo de óleo de 17\% é inferior a outras matérias-primas, como girassol, babaçu ou dendê e possui baixo rendimento por hectare $(0,2$ a $0,6 \mathrm{t} / \mathrm{ha})$.

Atualmente, além do grão, apenas o sebo bovino tem alguma representatividade. Em 2008, foi a matéria-prima utilizada para produzir $16 \%$ do biodiesel brasileiro. $\mathrm{O}$ Gráfico 3.3 representa a porcentagem das matérias-primas utilizadas para produção de biodiesel, segundo dados de outubro de 2009 da ANP. Interessante notar que, tanto o ólo de soja quanto o sebo bovino vão ter maior expressividade na região Centro-Oeste, que é a maior produtora de grãos de soja e gado bovino do Brasil. 


\section{Gráfico 3.3: Matérias-primas utilizadas para produção de biodiesel}

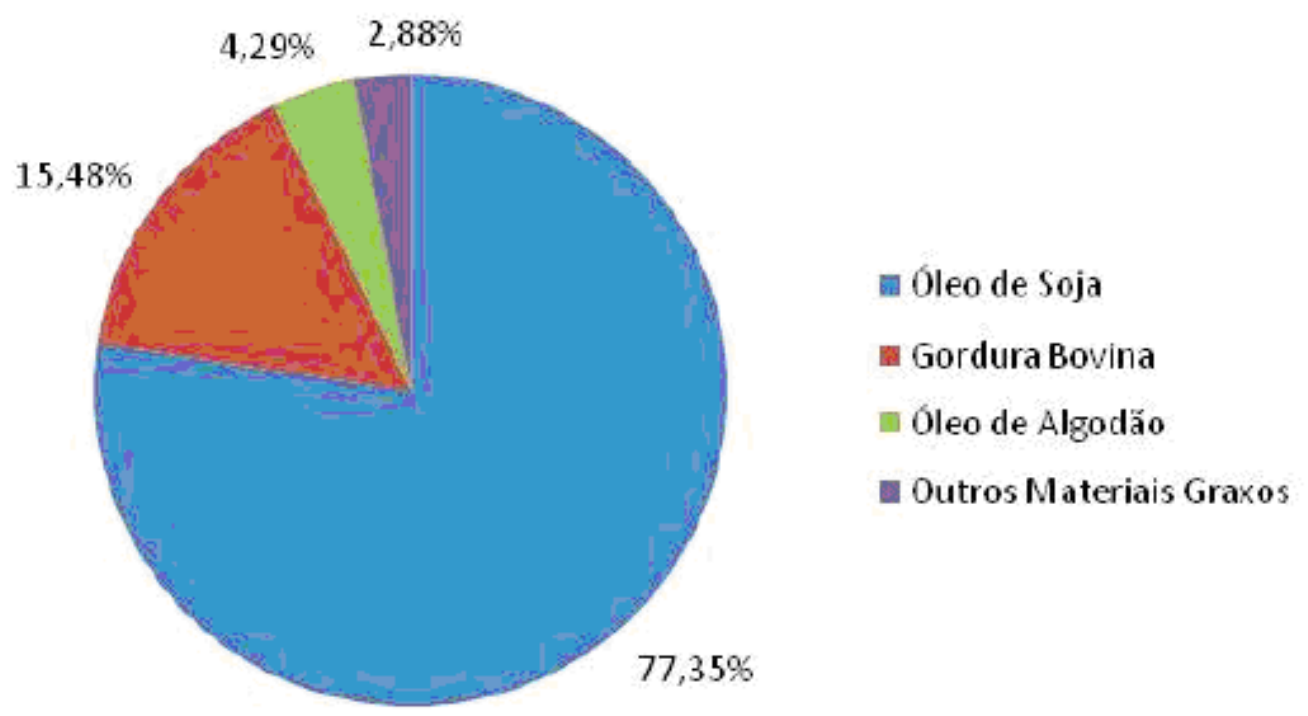

Fonte: ANP, outubro de 2009

No início do Programa Nacional de Produção e Uso de Biodiesel (PNPB) a participação da soja era marcante porque era um cultivo mais resistente aos ciclos de preços altos e baixos. De acordo com Ferres (2009), a soja tem $80 \%$ de farelo que é a proteína que também agrega valor à produção, pois é utilizado na alimentação animal. Então, quando o óleo cai de preço a soja não sofre tanto como amendoim, o girassol.

Assim, quando o governo brasileiro deixou de manter uma política de preços mínimos, houve uma concentração na produção da soja e do milho, porque são as culturas que menos dependem de preço de teor de óleo. Na opinião de Ferres (2009), o PNPB reverte essa lógica e cria um patamar de preços para as matérias-primas com teores de óleo mais elevados, como girassol, amendoim e mamona.

A soja teve sua produção significante no Brasil a partir de 1960, inicialmente na região sul. Com sua adaptação genética ao clima e solos do cerrado, houve sua expansão para região Centro-oeste, e o Mato Grosso passou a ser o principal estado produtor do país.

Entre as principais empresas que atuam no setor estão a ADM, Bunge, Cargill, Louis Dreyfus e Amaggi. Importante citar que a ADM, multinacional norte-americana, possui uma usina de biodiesel em Rondonópolis (MT). Hoje o Mato Grosso concentra 30\% 
da produção de soja do país, e lá se encontram facilmente latifúndios de 5 mil, 10 mil e 40 mil hectares, tendo o maior deles com mais de 150 mil hectares, localizado em Barra do Garça, norte do estado, limite com São José do Xingu. (IEA, 2009)

Com o surgimento do PNPB, e a consequiente necessidade de se adicionar aproximadamente $800 \mathrm{mil} \mathrm{m}^{3}$ de óleos vegetais nos cerca de 40 milhões de $\mathrm{m}^{3}$ de diesel mineral, a soja logo se apresentou como uma cultura indispensável nesse processo. A produção de biodiesel passou a ser vista pelo complexo sojeiro como mais uma opção, quase que uma válvula de escape, espécie de controle regulador de preços, evitando crises de excesso de oferta do grão.

Calcada em grandes unidades produtivas, no emprego de mão-de-obra relativamente qualificada, altamente capitalizada e tecnificada, insere-se totalmente no circuito superior da economia agrícola (IEA, 2009). Assim, a soja apresenta uma estrutura produtiva latifundiária e acaba contradizendo a lei que fixa que:

“O biodiesel necessário ao atendimento dos percentuais mencionados, terá que ser processado, preferencialmente, a partir de matérias-primas produzidas por agricultor familiar, inclusive as resultantes de atividade extrativista”. (Artigo 2, § 4 , Lei 11.097/2005).

Logo, o incentivo à agricultura familiar e inclusão social no campo, como previsto pelo Programa não é contemplado com esse tipo de ocupação. Os incentivos fiscais e tributários concedidos a empresas multinacionais com o intuito de produção de biodiesel não visam à produção local e de pequenos proprietários, não promovendo o desenvolvimento regional e sustentável, caráter conferido ao Programa Nacional de Produção e Uso de Biodiesel.

De acordo com dados da ANP, até outubro de 2009, o Brasil teve uma produção de 1.291.800 $\mathrm{m}^{3}$ de biodiesel B100, adicionados posteriormente ao diesel mineral e comercializados. O estado do Mato Grosso teve uma produção de $292.062 \mathrm{~m}^{3}$, equivalente a 22,6\% do total. O estado do Mato Grosso é representativo para este estudo haja vista sua importância como maior exportador de soja do país.

Do total de 61 plantas para a produção de biodiesel, 22 estão instaladas neste estado (ANP, setembro de 2008). É importante sublinhar que esta escala de produção é garantida através de uma estrutura concentrada da terra, bem como de arranjos políticos locais, 
parcerias entre setores públicos e privados que promovem a eficiência necessária a tais investimentos (Cafezeiro, 2008).

Sendo a área dedicada ao cultivo da soja mais de 120 vezes maior que a dedicada ao cultivo da mamona, aquela é, para a produção do biodiesel, uma espécie de antítese desta. Por isso, afirma-se que, ainda que seja evidente e concreto o apoio oficial do PNPB, dado à utilização de oleaginosas consideradas "alternativas", a produção brasileira de biodiesel ainda não deslanchou nesta direção. É justamente o inverso que ocorre, já que o que se vê é o fortalecimento do agronegócio, sobretudo o da soja na cadeia de produção do biodiesel brasileiro.

Em relação ao alcance do PNPB na geração de ocupação e renda entre os agricultores familiares, o Programa de Pós-Graduação em Administração de Organizações da FEA-RP/USP, junto aos produtores de Goiás, realizou uma pesquisa que mostrou que estados do Mato Grosso e Goiás tem avançado na produção se biodiesel em função das condições oferecidas pelo programa para a região Centro-Oeste como um todo.

Nesta pesquisa, buscou-se medir qual o nível de variação na renda e na ocupação dos produtores inseridos no PNPB. O critério adotado foi a renda informada pelos produtores, com suas atividades no contrato que firmaram para o fornecimento de matériaprima para o biodiesel, além da renda das demais atividades que continuaram a desenvolver (biodieselbr, 2008).

Constatou-se que a composição da renda familiar era constituída, principalmente, da produção de soja, algodão, milho, feijão e leite. Observou-se também que os produtores utilizavam em média 68 hectares para o desenvolvimento de suas atividades e diminuíram para 39 hectares, após a entrada no programa, uma redução, portanto, de 77,11\% em relação ao tamanho anterior. (biodieselbr, 2008).

A área média encontrada nos contratos para a produção de biodiesel foi de 42 ha, uma área considerada grande para agricultores familiares. Não é difícil entender que a cultura da soja exige áreas maiores, para ser economicamente viável, do que culturas como a mamona.

A área média da cultura voltada para o biodiesel, 42 ha, somada com a área destinada a outras atividades, 39 ha, totaliza uma área de 81,21 hectares em uso. Isto significa que os produtores que entraram no PNPB aumentaram, em média, de 68 para 81 hectares, o que representa uma variação de 19,44\% (biodieselbr, 2008). 
Podemos perceber, assim, que existe uma divisão, ao meio, da área contratada para produzir matéria-prima destinada ao biodiesel e aquela das demais culturas. Essa decisão indica uma opção dos produtores familiares pela diversificação.

O Gráfico 3.4 representa a porcentagem da participação dos produtores e a renda em cada atividade.

Gráfico 3.4: Participação dos produtores e a renda em cada atividade

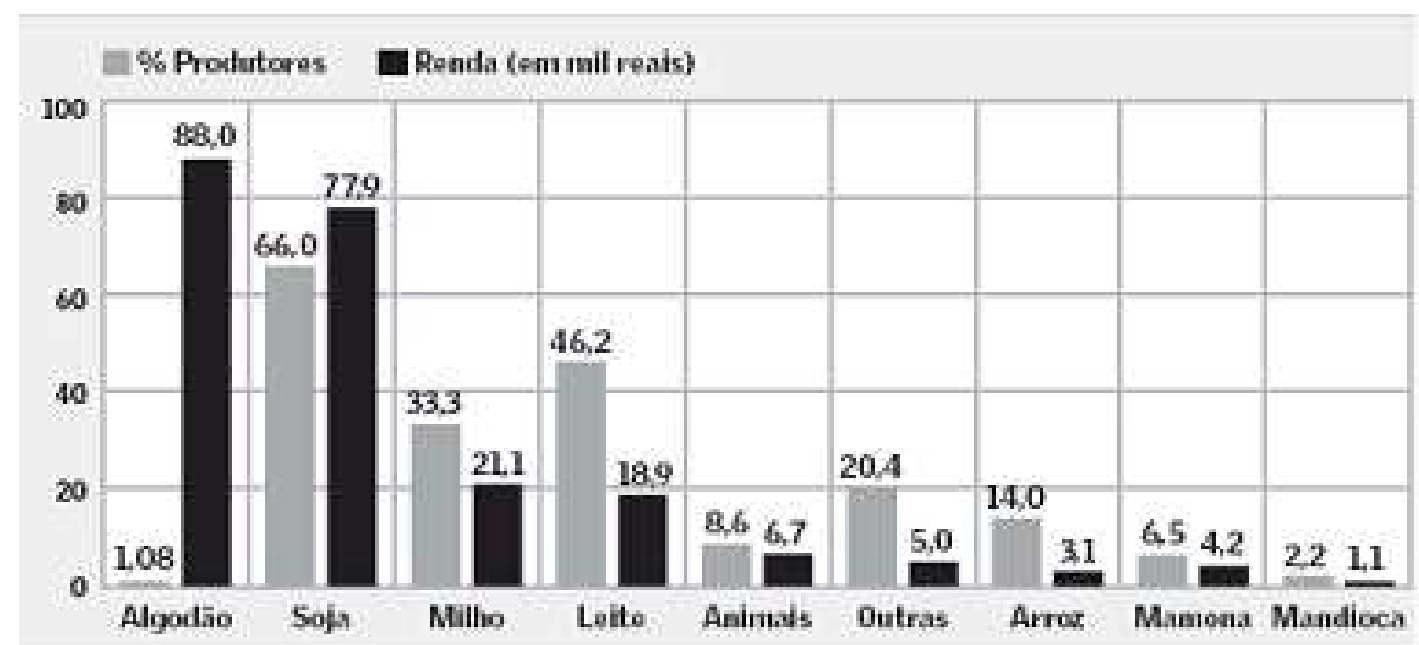

Fonte: biodieselbr, 2008

Percebemos, pelo gráfico, que a soja, o milho, o leite e o arroz são as atividades mais importantes, tanto do ponto de vista da renda quanto da presença dos produtores familiares. Observamos, também, que os contratos pelo PNPB, por enquanto, têm provocado pequena mudança, pois a soja já era uma cultura que compunha parte das atividades desses produtores, e a mamona ainda é insignificante. Por outro lado, entende-se que isso pode ser considerado bom para os produtores, pois continuam produzindo a cultura com a qual já têm experiência, ou seja, a soja.

De acordo com Cafezeiro (2008), diversas contradições aparecem ao confrontarmos a realidade e a proposta do Programa: o nível técnico exigido para a produção da soja e as possibilidades do pequeno produtor familiar; as dificuldades de localização dos mesmos na área "concentrada" da soja; as contradições existentes entre o discurso da preservação ambiental e o que vem sendo realizado neste estado.

A partir das contradições expostas acima e das reflexões da geografia sobre a apropriação e uso dos espaços, é que nos debruçamos sobre essa problemática, onde Santos 
(2000) sugere que "há transformação do meio natural em técnico e em meio técnicocientífico-informacional em função da extensão e densidade dos objetos técnicos e de lógicas esquizofrênicas".

Como se sabe, hoje, a agroindústria se apropria das possibilidades geradas pelas novas tecnologias para garantir maior acúmulo de capital. Tais investimentos aumentam as possibilidades de êxito do território, gerando maior inserção na economia global. Segundo Santos (2000), essa escolha gera localmente "um efeito desestruturador: cria novos papéis, estranhos à sociedade local e gera impactos ambientais de diversas ordens" (Santos, 2000).

Tais formas resultantes, que já ocorrem no espaço brasileiro com a agroindústria da soja, podem se tornar cada vez mais dominantes dependendo do modelo que seja implementado para a produção do biodiesel. Necessitamos, portanto de estudos que acompanhem as políticas públicas voltadas para esta atividade econômica, bem como uma maior compreensão das áreas aonde tais dinâmicas já vêm ocorrendo (Cafezeiro, 2008).

Logo, percebe-se que o PNPB tem provocado pouca mudança de cultura, pois a soja que já era utilizada ainda prevalece nos cultivos do Centro-oeste e apresenta uma grande participação na produção de biodiesel. Porém, esse cultivo é dominante monocultor e de grandes propriedades favorecendo a concentração de terra e capital, sem atender aos princípios iniciais do Programa de inclusão social e agricultura familiar.

Ainda, a soja é a matéria-prima que apresenta menor produtividade de óleo por hectare, enquanto outras fontes de óleo vegetal como palmáceas em geral (dendê, macaúba, babaçu) apresentam maior rendimento de óleo na produção. Tais culturas devem ser estimuladas por políticas públicas para promover o desenvolvimento agrícola do campo como maior eficiência e para atendimento das premissas do PNPB. 


\section{4 - O PROCESSO DE DESMATAMENTO DA AMAZÔNIA}

\subsection{Contextualização Econômica}

A região amazônica possui uma grande heterogeneidade biogeográfica e diferentes formas de ocupação humana, incorporadas na paisagem a partir de diversos padrões espaciais, que podem estar associados aos diferentes atores, tipos e históricos de ocupação (Costa et al., 2007).

A Amazônia está associada a uma área aproximadamente 7,5 milhões de $\mathrm{km}^{2}$, localizada na porção centro-oriental da América do Sul, cortada pela Linha do Equador. Tem clima quente e úmido e é coberta por densa floresta tropical úmida - a Floresta Amazônica.

Banhada por uma intricada e extensa rede hidrográfica, tem o rio de maior volume de água do mundo, o Solimões-Amazonas como eixo principal. É habitada por uma população rarefeita constituída basicamente de indígenas ou caboclos e que abriga riquezas naturais incalculáveis.

As mudanças na região amazônica estão fortemente associadas aos processos de desenvolvimento socioeconômico, onde a ocupação do território ocorre de maneira desordenada e sem planejamento. É importante o desenvolvimento de estudos para um melhor entendimento dos complexos processos antrópicos que atuam nos sistemas terrestres.

As mudanças de uso e ocupação do solo podem ser percebidas a partir da identificação da ação de diferentes atores envolvidos nesses processos: populações tradicionais, agricultores familiares, fazendeiros, madeireiros e mineradores.

Até 1960, o perfil econômico da região Amazônica estava baseado nas atividades extrativistas primárias, mas os projetos econômicos promovidos com o incentivo ao Estado, nos chamados Pólos de Desenvolvimento da Amazônia, ligados à exploração agropecuária, floresta e mineral e ao desenvolvimento industrial mudaram esse perfil.

A Amazônia passou a representar uma região de expansão da fronteira econômica nacional, cuja ocupação ocorreu com base em empreendimentos agropecuários e de atividades econômicas diversas.

Com a ditadura militar, a partir de 1964, o processo desenvolvimentista e de segurança nacional enfatizava os aspectos geopolíticos do processo de ocupação da 
Amazônia ("integrar para não entregar"). Além da abertura de estradas e asfaltamento das já existentes, outras ações foram tomadas pelos governos militares na Amazônia:

- Criação da Superintendência para o Desenvolvimento da Amazônia (Sudam) substituindo a SPVEA (Superintendência do Plano de Valorização Econômica da Amazônia);

- Criação da Superintendência da Zona Franca de Manaus (Suframa);

- Implantação de Programas de colonização que incluíam o assentamento de famílias de trabalhadores rurais;

- Desenvolvimento de Projetos Agropecuários;

- Implementação de projetos de exploração mineral;

- Construção de obras de infra-estrutura, como hidrelétricas e portos para escoamento da produção.

De qualquer forma, tais obras e projetos contaram com a participação de grupos estrangeiros interessados em explorar os abundantes recursos da região.

Em 1966, institui-se a Amazônia Legal (AC, PA, AM, AP, RR RO e áreas do MT, GO e MA) e a Sudam, além de organizações para captação de créditos e incentivos como o Banco da Amazônia.

A Suframa foi criada um ano depois da Sudam e tinha por responsabilidade planejar e coordenar a transformação da cidade em um centro industrial de grande porte. Para promover a instalação de indústrias, a Zona Franca foi definida como área isenta de impostos de importação, podendo comprar peças a baixo custo do exterior e montar produtos de bens de consumo, como eletrodomésticos, voltados para o Centro-Sul brasileiro.

Ao longo da década de 70, a ditadura implantou o Projeto Radam (radares para a Amazônia) e construiu a infra-estrutura viária - Transamazônica, Cuiabá-Santarém, Manaus-Rio Branco, Perimetral Norte - ferroviária - Carajás-Itaqui - e energética - Usinas hidrelétricas de Tucuruí, Balbina e Samuel.

Com as pesquisas realizadas pelo Projeto Radam-Brasil foi feito o inventário das reservas, sendo possível observar áreas minerais muito promissoras. Observa-se que até 1969, com exceção da exploração empresarial do manganês por uma empresa norteamericana na Serra do Navio, no Amapá, a exploração mineral era uma das alternativas de pequenos produtores, ex-lavradores que perdiam suas terras e que exploravam o ouro e o 
diamante, produtos de elevado valor por unidade de peso e que não demandavam infraestruturas complexas e pesadas.

A partir de 1970, a exploração se volta para a produção de matérias-primas para fins industriais, como o ferro, o cobre, a bauxita, demandando maior infra-estrutura de transportes de energia. O Estado se fez fortemente presente nesses setores com empréstimos internacionais.

Na década de 1970, foi instituído o Projeto Trombetas, envolvendo a exploração da bauxita de jazidas localizadas no Vale do Rio Trombetas, no Pará. Em 1980, foi criado o Programa Grande Carajás, com associação de empresas estatais que se associaram ao capital privado nacional e transnacional para exploração de jazidas de ferro, manganês, níquel, estanho, entre outros minérios.

As rodovias Belém-Brasília e Brasília-Acre se tornaram eixo de ligação entre a área mais industrializada e economicamente desenvolvida, o Centro-Sul e a "grande fronteira de recursos do país”, a Amazônia. Surgiram grandes projetos agropecuários e de extração mineral, desenvolvidos por grupos estrangeiros e nacionais beneficiados por incentivos da Sudam (Torres, 2005).

Em 1985, o Projeto Calha Norte surgiu com o objetivo de estabelecer o controle militar sobre a área, na qual as fronteiras internacionais não estavam precisamente demarcadas e para disciplinar a ação de garimpeiros, inibir o narcotráfico, garantir a integridade territorial das reservas indígenas e prestar apoio às comunidades ali localizadas.

Em 1990, surge o Projeto Sivam - Sistema de Vigilância da Amazônia - para vigiar a Amazônia Legal por meio de uma rede integrada de comunicações, envolvendo aviões, radares fixos, satélites que forneceriam dados e informações destinadas ao controle aéreo da região, identificar os focos de incêndio nas matas e mapear os recursos naturais da região.

Em 24 de agosto de 2001, o presidente Fernando Henrique Cardoso, na medida provisória $\mathrm{n}^{\mathrm{o}}$. 2.157-5, criou a Agência de Desenvolvimento da Amazônia (ADA) e extinguiu a Sudam. Essa decisão foi tomada após várias críticas quanto à eficiência desta autarquia, passando a ser a responsável pelo gerenciamento dos programas relativos à Amazônia Legal. Em agosto de 2003 o presidente Luiz Inácio Lula da Silva recriou a Sudam. 
Em relação à expansão do agronegócio, um grande número de empresas agropecuárias implantou projetos na Amazônia. Foram mais de 580, concentrados principalmente na região do Araguaia mato-grossense e paraense e no atual Estado do Tocantins. Aliás, Mato Grosso e Pará foram os estados que receberam o maior número de projetos agropecuários incentivados pela Sudam (mais de 400 - 72\% do total) (Oliveira, 2005).

Depois, aparece a porção leste do PA (área de Paragominas) e, com menor incidência, o Amazonas, na área próxima a Manaus, em direção a Roraima e ao Pará. A distribuição espacial dos projetos demonstra que a região do Araguaia mato-grossense corresponde à área de maior concentração.

A tabela 4.1 mostra a distribuição dos projetos agropecuários aprovados pela Sudam na década de 60 .

Tabela 4.1 - Distribuição dos projetos aprovados pela Sudam na década de 1960

\begin{tabular}{|c|c|c|}
\hline ESTADO & NÚMEROS & \% \\
\hline Pará & 212 & $37 \%$ \\
\hline Mato Grosso & 207 & $35 \%$ \\
\hline Goiás & 52 & $9 \%$ \\
\hline Amapá & 29 & $5 \%$ \\
\hline Maranhão & 24 & $4 \%$ \\
\hline Amazonas & 22 & $4 \%$ \\
\hline Acre & 18 & $3 \%$ \\
\hline Rondônia & 11 & $2 \%$ \\
\hline Roraima & 6 & $1 \%$ \\
\hline TOTAL & $\mathbf{5 8 1}$ & $\mathbf{1 0 0 \%}$ \\
\hline
\end{tabular}

Fonte: Oliveira, 2005

Projetos agroindustriais representavam 40 entre 947 projetos da Sudam. Os incentivos fiscais ficavam a cargo do Tesouro Nacional, e os projetos que não cumprissem as normas poderiam ser cancelados e deveriam devolver o dinheiro ao Tesouro Nacional pelos valores históricos das quantias recebidas.

Foi por essa razão que a maior parte dos grandes grupos econômicos, nacionais ou estrangeiros, criou suas agropecuárias, pois assim podiam desviar dinheiro do imposto de 
renda. A área ocupada pelos projetos agropecuários e agroindustriais na Amazônia Legal abrangeu mais de 9 milhões de ha, sendo 31.400 ha no Mato Grosso (Oliveira, 2005).

Logo, a ditadura militar construiu uma imagem da Amazônia como se fosse uma nova "terra de oportunidades", celebrando a força do homem contra a natureza e acentuando traços catastróficos da mentalidade colonialista em relação à região. Essas concepções permaneceram, principalmente com a propaganda e incentivo ao agronegócio e as conquistas tecnológicas da biogenética, como necessárias para o processo civilizatório gerando riquezas para a nação e alimentos (Torres, 2005).

A ocupação da região obedeceu a lógica do colonizador, ancorada na idéia de apropriação da natureza, sempre subordinada aos interesses do capital internacional e da elite, que nunca criou um projeto genuinamente integrador com uso dos potenciais criativos dos brasileiros a partir das várias classe econômicas. 


\subsection{O desmatamento na Amazônia}

A Amazônia abriga vastos recursos naturais e muitas vezes vista como vazio demográfico, portanto vulnerável a eventuais pretensões de potências internacionais. Nesse espaço, a habitação se torna um desafio à inteligência e à convivência com a diversidade, que ocorre na Amazônia da mata e numa Amazônia desmatada.

$\mathrm{Na}$ Amazônia desmatada a ocupação é dada pelo pasto, geralmente latifundiário, e os plantios camponeses. Já a Amazônia da mata é habitada de múltiplas comunidades indígenas, caboclas, ribeirinhas, extrativistas, negras remanescentes de quilombos, de mulheres quebradeiras de coco de babaçu, de migrantes recém-chegados que, tal e qual o migrante anterior, se vê desaparelhado culturalmente para viver com ecossistemas extremamente delicados e complexos.

Nos últimos anos, particularmente a partir da década de 1960, com a abertura da Rodovia Bernardo Sayão a Belém-Brasília, e da criação da Suframa, a região vem passando por um intenso processo de transformação na organização do seu espaço geográfico.

Sob o regime ditatorial, o Estado adquiriu muitos empréstimos em bancos privados e multilaterais (BID - Banco Interamericano de Desenvolvimento - e BIRD - Banco Internacional de Reconstrução e Desenvolvimento) além da entrada de corporações transnacionais que obtinham vantagens fiscais e redução de impostos.

Como se fosse região colonial, um vazio demográfico e somente portadora de recursos naturais, a Amazônia se transformou num cenário de enormes tensões e conflitos, além de devastações, exploração, violência e resistência.

Atualmente, o crime organizado na Amazônia atua por meio de fraudes financeiras, narcotráfico, biopirataria, desmatamento por meio da extração e comércio ilegal de madeira nativa e ação de pecuaristas no processo de grilagem de terras para confirmar posses, atividades associadas, tais como tráfico de armas, de pedras preciosas, trabalho escravo, comércio de carros roubados e de carga de caminhões roubadas, entre outras.

Entretanto, tais termos não são fenômenos novos no cotidiano amazônico. O que se observa é uma nova configuração que vem se instituindo no contexto de reorganização societária em curso no mundo atual. Esse processo de reorganização societária tem tido o ambientalismo como um de seus principais vetores (Gonçalves, 2005).

A própria configuração da Amazônia é uma construção erguida no bojo da ordem mundial que se foi desenhando com o colonialismo, o imperialismo, e os marcos do 
processo de reorganização societária em curso, que aponta a uma nova escala de organização territorial que supera muitas vezes a participação do Estado Territorial Moderno (Gonçalves, 2005).

Nas últimas décadas, o processo de ocupação e de exploração dos recursos naturais da Amazônia intensificou o ritmo de deflorestamento na região. A devastação pressiona a floresta amazônica de maneira constante, seguindo-se via de regra três etapas consecutivas de exploração comercial: primeiro a retirada de madeira, em seguida o estabelecimento de pastagens e por fim o plantio da soja.

Entretanto, o desmatamento progressivo tem gerado a fragmentação e perda de grandes áreas e de floresta. Há uma infinidade de espécies que estão desaparecendo antes que os pesquisadores tenham tempo de registrá-las, ameaçando o equilíbrio do ecossistema e a biodiversidade existente nesse domínio natural.

Vários estudos, produzidos a partir de levantamentos de campo e por sensoriamento remoto (imagens de satélite e radar), mostram um progressivo aumento da área deflorestada na região Amazônia.

A maioria dos desmatamentos está concentrada em uma faixa de terras que se estende desde o nordeste do Pará, passando pelo noroeste do Maranhão e Tocantins, pelo norte do Mato Grosso, seguindo por Rondônia e chegando ao Acre. É o chamado arco de deflorestamento da Amazônia, que está representado na figura 4.1. 


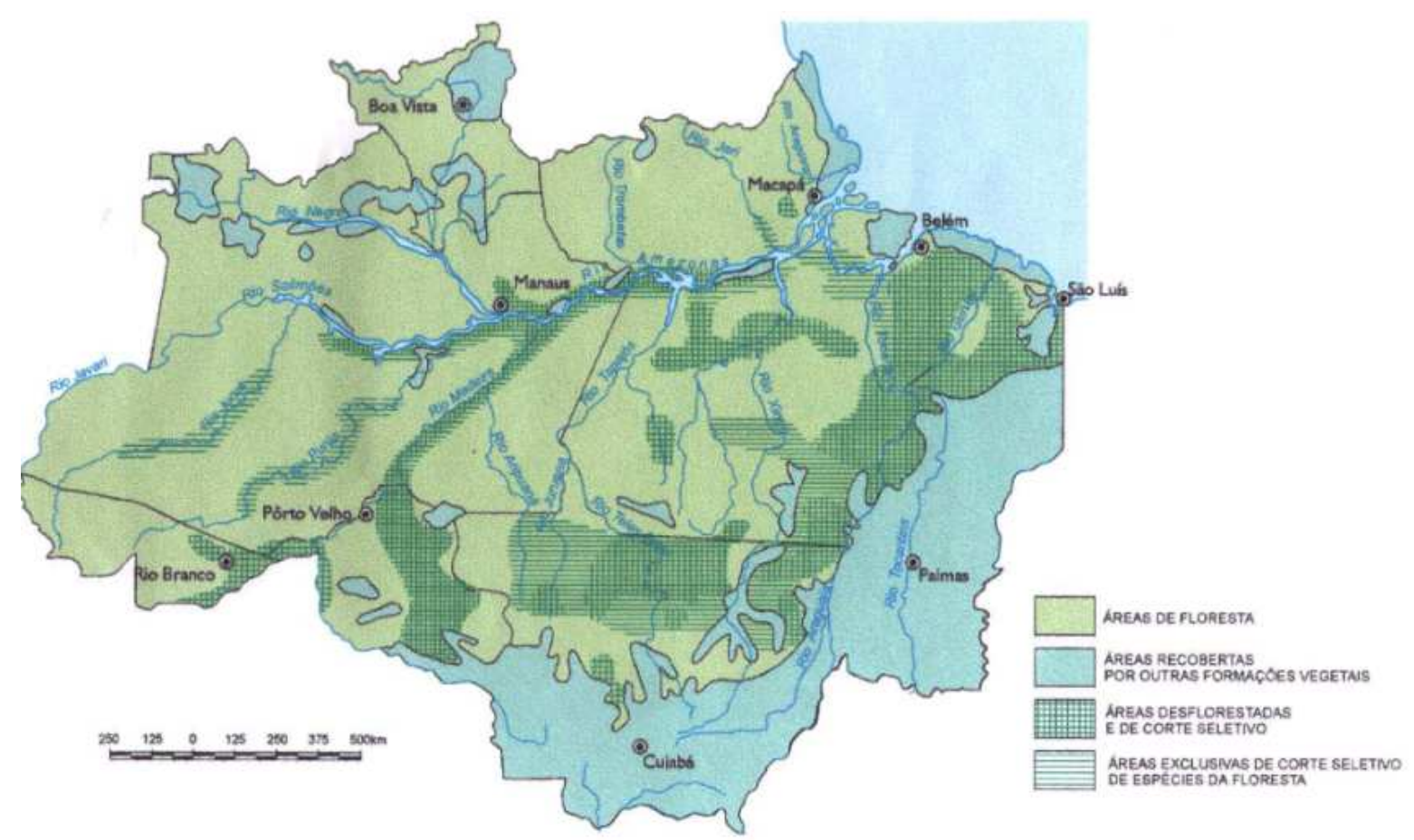

Fonte: IBGE, 2000

Figura 4.1 - Arco de deflorestamento da Amazônia

$\mathrm{Na}$ figura 4.1 nota-se que a área que abrange a o arco de deflorestamento corresponde ao norte do Mato Grosso, desde divisa com Roraima a noroeste, estendendo-se pela divisa com Pará até a divisa com Tocantins a nordeste.

A região de São José do Xingu, no nordeste do Mato Grosso, divisa com estado do Pará, está inserida no arco de deflorestamento e de expansão da fronteira agrícola. Por isso, e pela representatividade que a região apresenta como potencial produtora de soja foi escolhida como área de estudo. O subcapítulo 3 descreve a história dos municípios e arredores.

Em relação ao desmatamento na Amazônia, segue a tabela 4.2 que mostra estimativas do ritmo de desmatamento da Floresta nas últimas décadas. 


\begin{tabular}{|c|c|c|c|c|c|c|c|}
\hline \multicolumn{7}{|c|}{ Tabela 4.2 - Estimativas anuais desde 1988 até 2006 em anos selecionados } \\
\hline \multicolumn{1}{|c|}{ Taxa de desmatamento anual (km²/ano) } \\
\hline Estados & $\mathbf{1 9 8 8 *}$ & $\mathbf{1 9 9 1}$ & $\mathbf{1 9 9 4 * *}$ & $\mathbf{1 9 9 7}$ & $\mathbf{2 0 0 0}$ & $\mathbf{2 0 0 3}$ & $\mathbf{2 0 0 6 * * *}$ \\
\hline Acre & 620 & 380 & 482 & 358 & 547 & 1061 & 323 \\
\hline Amapá & 60 & 410 & & 18 & & 25 & 30 \\
\hline Amazonas & 1510 & 980 & 370 & 589 & 612 & 1587 & 780 \\
\hline Maranhão & 2450 & 670 & 372 & 409 & 1065 & 993 & 651 \\
\hline Mato & $\mathbf{5 1 4 0}$ & $\mathbf{2 8 4 0}$ & $\mathbf{6 2 2 0}$ & $\mathbf{5 2 7 1}$ & $\mathbf{6 3 6 9}$ & $\mathbf{1 0 4 0 5}$ & $\mathbf{4 3 3 3}$ \\
Grosso & & & & & & & \\
\hline Pará & 6990 & 3780 & 4284 & 4139 & 6671 & 6996 & 5505 \\
\hline Rondônia & 2340 & 1110 & 2595 & 1986 & 2465 & 3620 & 2062 \\
\hline Roraima & 290 & 420 & 240 & 184 & 253 & 439 & 231 \\
\hline Tocantins & 1650 & 440 & 333 & 273 & 244 & 156 & 124 \\
\hline Amazônia & $\mathbf{2 1 0 5 0}$ & $\mathbf{1 1 0 3 0}$ & $\mathbf{1 4 8 9 6}$ & $\mathbf{1 3 2 2 7}$ & $\mathbf{1 8 2 2 6}$ & $\mathbf{2 5 2 8 2}$ & $\mathbf{1 4 0 3 9}$ \\
\hline
\end{tabular}

Fonte: http://www.obt.inpe.br/prodes/prodes_1988_2006.htm

* Média entre 1977 e 1988

** Media entre 1993 e 1994

****Taxas Anuais de 2005 e 2006

A tabela 4.2 mostra que o estado do Mato Grosso teve um avanço muito grande no desmatamento, com dados representam $41 \%$ do total no ano de 2003 . Isso chegou a representar uma taxa de desmatamento de $133 \%$ no estado de 2002 e 2003. Dados sobre a representatividade da expansão da soja sobre a floresta e especificamente do estado do Mato Grosso Serão trabalhados no subcapítulo 4.3.

Uma das principais técnicas utilizadas para abertura de pastos e área agriculturável na Amazônia são as queimadas. O subcapítulo 4.1.1 pretende trabalhar esse assunto.

\subsubsection{Queimadas}

Alguns dos impactos ambientais sobre a região estão associados às técnicas utilizadas na agropecuária que ainda repete métodos empregados há 30 anos, em que pese o avanço da tecnologia nesse tipo de sistema. 
Em geral, a abertura das áreas se inicia com a atividade madeireira. O trabalho de máquinas na floresta e a queda e extração das árvores causam movimentação do solo. Além disso, apesar dos madeireiros terem como objetivo as espécies que têm valor econômico, sua derrubada acaba arrastando outras árvores, menos valorizadas, e arrasando-as por tabela.

O passo seguinte da limpeza é o chamado correntão. Essa etapa consiste em dois tratores atados às extremidades de um cabo de aço ou de uma corrente de mais ou menos 20 metros de comprimento, que andam paralelos pelo terreno, arrancando as árvores desde a raiz. Além de suprimir a cobertura vegetal de áreas inteiras, a prática também causa movimentação do solo. Depois coloca-se fogo em todo o resto, que é enfileirado e passa-se os tratores com correntão que arrastam as árvores e o mato remanescente e deixando o solo livre, finalmente, para a semeadura do pasto ou da lavoura.

Agricultores freqüentemente utilizam técnicas como queimadas para limpar terras e na abertura de novas áreas para uso agropecuário. O fogo é considerado uma técnica de manejo barata e faz parte de todas as formas de uso do solo da região. É muito comum a utilização do fogo para a recuperação de pastagens degradadas, o controle de pragas, a abertura de novas áreas e o plantio.

Entretanto, em vez de queimar os 2-10 acres (1-4 ha) que pretendiam cultivar, agricultores queimam centenas de milhares de hectares. Esta técnica é geralmente um desperdício porque uma vez que as árvores são removidas antes do tempo, a mesma é cortada e colocada para secar. Após o corte, a área é queimada para liberar nutrientes e produzir uma camada de material rico acima dos solos pobres da antiga floresta tropical.

A área é apagada rapidamente e plantada apóia crescimento vigoroso durante alguns anos, após os quais os nutrientes são esgotados e ações abundância de fertilizantes são necessárias para manter a operação viável.

Primeiro, ateia-se fogo na mata e depois semeia-se a braquiária, gramínea que servirá de alimento para o gado. Parte da mata que restou na primeira queimada não resistirá, contudo, no ano seguinte. A braquiária é uma espécie invasora agressiva e se alastra rapidamente.

Na próxima estação seca, a grande quantidade de biomassa formada no período, ou seja, a quantidade de material vivo existente na área, naquele momento, que pode incluir 
também organismos mortos como cascas de árvore, gramíneas, torna-se um combustível a ser queimado.

Os incêndios florestais rasteiros podem eliminar até $80 \%$ da biomassa florestal acima do solo, sendo que as árvores que restaram morrem lentamente ao longo do tempo. A atividade madeireira leva ao "esgarçamento" da floresta, facilitando o alastramento do fogo mesmo em áreas preservadas. Além disso, a queimada para desmatar a floresta é responsável por $75 \%$ das emissões de gases do efeito estufa.

O estudo intitulado "O custo econômico do fogo na Amazônia", do Instituto de Pesquisas de Economia Aplicada (Ipea), estima que os custos anuais das queimadas na região do Mato Grosso são da ordem de US\$ 102 milhões, tendo em vista a destruição acidental de cultivos, pastos e benfeitorias; as perdas associadas a doenças respiratórias provocadas pela fumaça e a perda de carbono das florestas. O estudo aponta que esse resultado pode ser até 45 vezes maior, dependendo de como é valorado o carbono liberado pela floresta.

A figura 4.2 mostra uma queimada na área de Floresta.

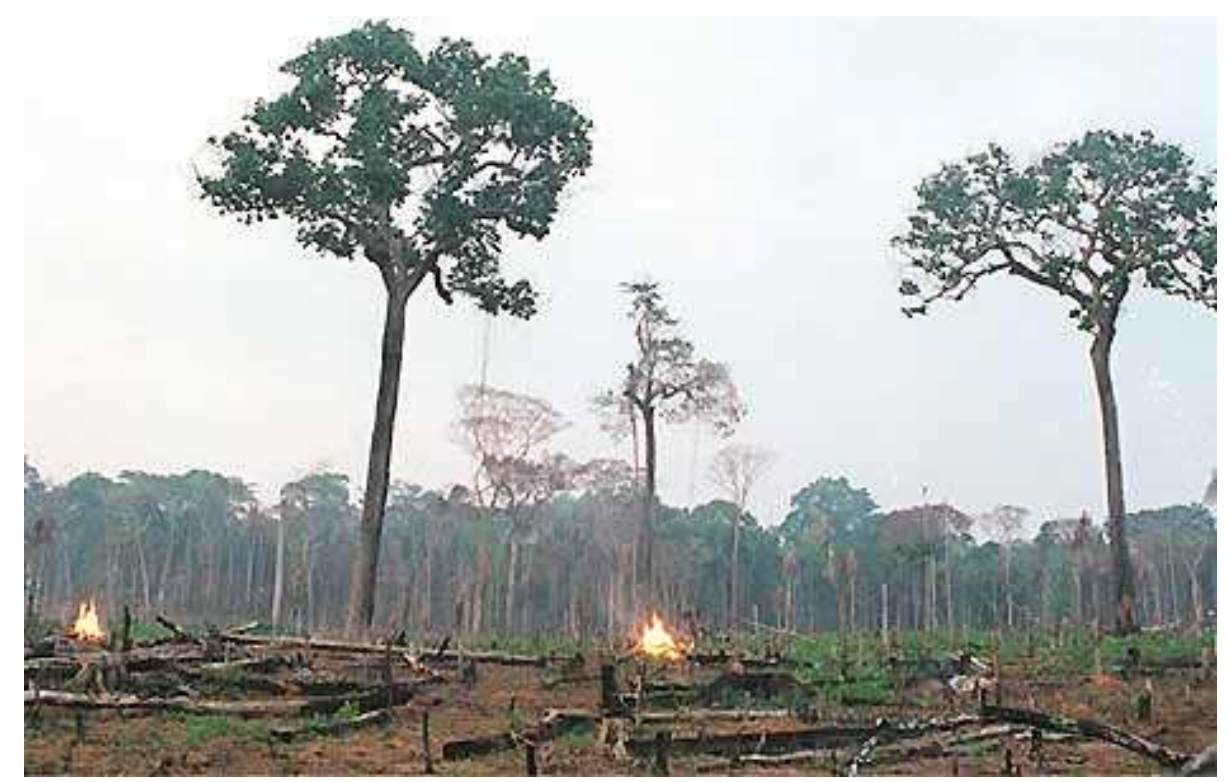

Fonte: http://www.socioambiental.org/esp/soja.br

Figura 4.2: Queimada em área de floresta 


\subsection{Expansão da soja e Desmatamento}

Em relação às áreas de expansão da soja, verificou-se que o crescimento agrícola recente se caracterizou por um aumento muito rápido: nada menos que $22,8 \%$ da área plantada ao longo de apenas três anos agrícolas (2001/2002, 2002/2003 e 2003/2004).

Essa expansão recente difere radicalmente do padrão que prevaleceu durante toda a década de 90, quando a área agrícola total com lavouras permaneceu constante e todo o aumento da produção deveu-se ao crescimento da produtividade. Considerando os três anos agrícolas do período que vai de 2001 a 2004, a expansão foi de 39,8\% nas regiões Sul e Sudeste e 66,1\% na região Centro-Oeste (Brandão, 2005).

Sobretudo por conta de incentivos para a produção de soja, a disponibilidade e a oferta de terras para cultivo e a introdução de novas tecnologias e de sementes mais adaptadas ao clima tropical chuvoso da Amazônia. A soja vem, portanto, se expandindo sobre as áreas de floresta e, apesar de muitos produtores agrícolas estarem utilizando antigas pastagens para plantar soja, grandes extensões de floresta não estão sendo poupadas.

O domínio vegetacional que se estabelece na região de avanço agrícola é a Floresta Amazônia que representa um dos ecossistemas de maior importância no mundo devido à colaboração na regulagem climática, através evapotranspiração e seqüestro de carbono, a conservação da biodiversidade, entre outros benefícios.

Porém, isso não impediu que houvesse abertura de novas áreas para a monocultura da soja, às custas do desmatamento de florestas, o que pode intensificar processos de erosão, perda de solo e lixiviação.

$\mathrm{Na}$ pesquisa realizada pelo GT Florestas do FBOMS em Mato Grosso, foram analisadas as áreas onde ocorreram os maiores desmatamentos ilegais nos anos de 2001, 2002 e 2003, incluindo a evolução do uso do solo e a freqüência da conversão de uma modalidade de uso para outra. Em 2004/2005, foram plantados 1,2 milhões de hectares de soja na Floresta Amazônica brasileira, o que representa cerca de 5\% da área plantada nacional

Segundo relatório do Greenpeace “Eating Up the Amazon”, de 2006, desde o início de 2002 até abril de 2006 foram destruídos setenta mil quilômetros quadrados da Floresta Amazônica. Somente entre 2003 e 2004, foram 27 mil quilômetros quadrados, sendo que três quartos dessa área foram destruídos ilegalmente. 
Em Mato Grosso, na região Centro-oeste, a área plantada com soja aumentou 400\% nos últimos dez anos. O plantio começou nos cerrados centrais e migrou para o norte cerca de 500 quilômetros, deslocando a fronteira agrícola.

O domínio vegetacional que se estabelece na região de avanço agrícola é a Floresta Amazônia que representa um dos ecossistemas de maior importância no mundo devido à colaboração na regulagem climática, através evapotranspiração e seqüestro de carbono, a conservação da biodiversidade, entre outros benefícios.

Simetricamente, no mesmo período, a área desmatada no estado aumentou em dimensões semelhantes e de forma progressiva, até chegar ao aumento de $133 \%$ apontado pelo governo estadual entre 2002 e 2003.

Abaixo, segue o gráfico 4.1 que ilustra o aumento das plantações de soja no estado.

\section{Gráfico 4.1 - Evolução da produção de soja no Estado do Mato Grosso}

1976 -2005.

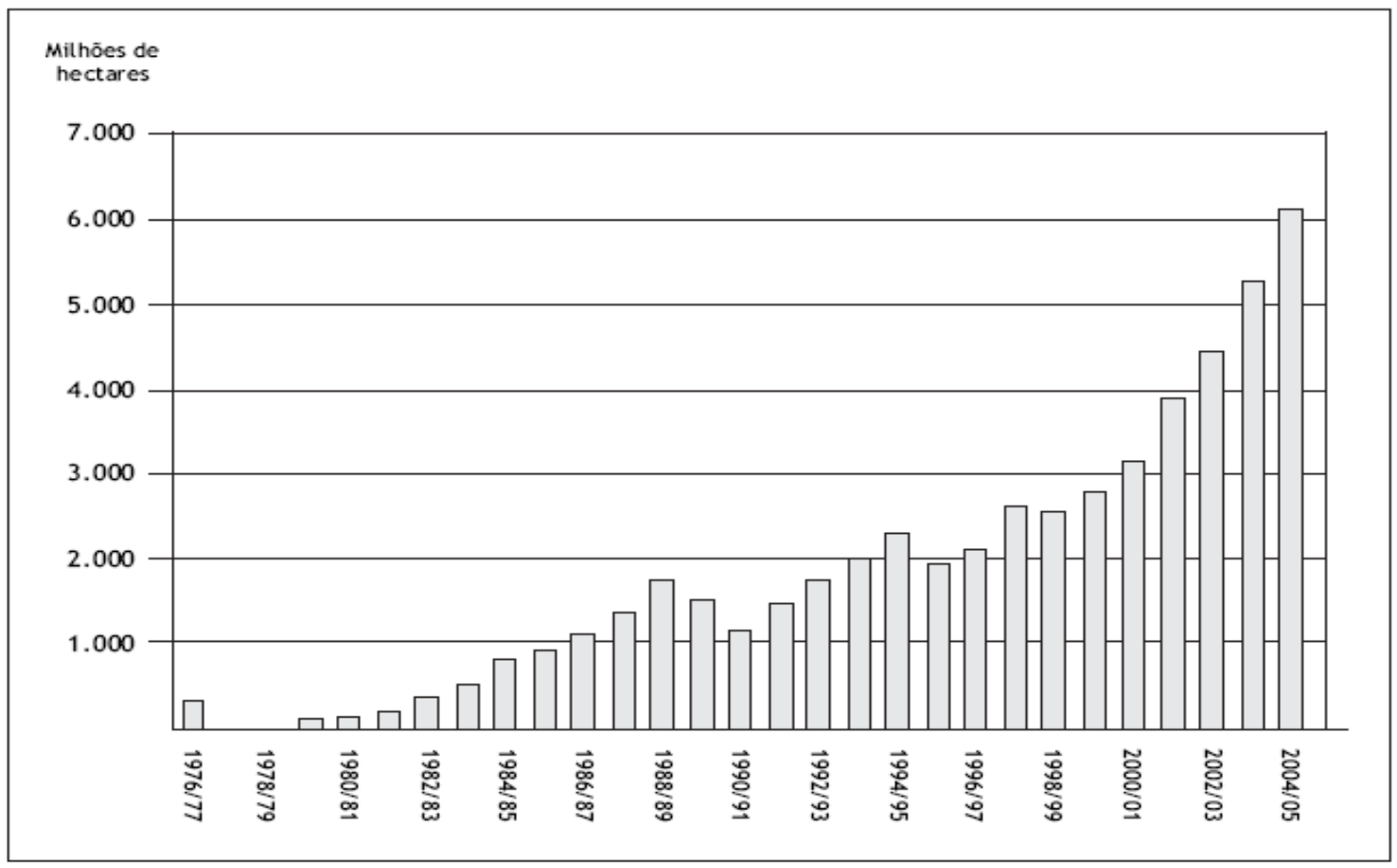

Fonte: Conab, jan/ 2006

Isso corresponde a um crescimento percentual de $6 \%$ em relação ao período anterior, ou seja, cerca de 26.130 quilômetros quadrados de desmatamento, grande parte dele causado pela expansão da soja (Schlesinger, 2006).

Cerca de $90 \%$ do cultivo de soja em áreas amazônicas ocorre no Mato Grosso. O estado de Mato Grosso vem apresentando um significativo desenvolvimento agrícola nos 
últimos trinta anos. Essa vasta região tropical situa-se ao sul da floresta amazônica, dominada por uma vegetação natural constituída majoritariamente pelo cerrado (savana arbórea). Entretanto, o avanço da fronteira agrícola rumo ao norte tem provocado uma rápida substituição da cobertura vegetal natural pelas lavouras de soja, que se tornou a maior fonte de renda do estado (Arvor et al., 2007).

A região noroeste de Mato Grosso apresenta uma grande extensão de terras protegidas, populações tradicionais e assentamentos rurais. Essa região vem sofrendo fortes pressões devido a interesses econômicos diversos, como a exploração de minérios, de madeira e a expansão da pecuária, provocando conflitos com as populações locais e o comprometimento da floresta e da biodiversidade. As regiões do noroeste do estado são aquelas que mais crescem em termos demográficos.

Boa parte desse crescimento se deve ao surgimento de novos núcleos rurais. $\mathrm{O}$ noroeste de Mato Grosso se configura como alternativa para a absorção de um grande contingente de pessoas que exerce atividades ligadas a terra. A duração do ciclo de culturas nas áreas recém-desmatadas está se tornando mais curta.

Esse processo é mais evidente nas regiões que já possuem uma fronteira agrícola relativamente consolidada, além de acesso à infra-estrutura e topografia plana. Há indícios de que o prazo de aproximadamente cinco anos entre o desmatamento e a mecanização estimado pela maior parte dos observadores esteja se reduzindo para aproximadamente dois a três anos. Em 20\% dos casos analisados, o prazo foi de apenas um ano (FBOMS/ISA, 2007).

De acordo com as informações do Greenpeace, mais de um milhão de hectares de florestas foram convertidos em campos de soja na Amazônia, mesmo com estudos que apontam que a fragilidade do solo da região não sustenta mais que três anos de produção sojeira e alertam para uma possível contaminação de lençóis freáticos por agrotóxicos (Bermann et al, 2007).

Esse debate gerou uma polêmica especial quando, em julho de 2005, foi apresentado pelo IPEA um estudo intitulado "Crescimento agrícola no Brasil no período 1999-2004: explosão da soja e da pecuária bovina e seu impacto sobre o meio ambiente”. O documento analisa os fatores que levaram ao crescimento da produção de soja no Brasil. 
A principal controvérsia surgiu no tópico chamado "A soja deve ser vista como amiga ou inimiga da floresta amazônica?" Ali se afirma que a expansão da soja ocorria por meio do uso das áreas utilizadas anteriormente para pecuária.

Outra tese apresentada é que as melhorias de infra-estrutura na região amazônica levariam ao aumento do preço da terra e, com isso, à sua utilização mais racional, ou seja, esse processo modernizaria a agricultura nortista, transformando as atuais atividades predominantes na região, e que são responsáveis pelo atual uso predatório da floresta: Seriam elas:

a) a agricultura itinerante, de baixo nível tecnológico e usuária do fogo para abertura de área;

b) a extração irracional de madeira;

c) a atividade pecuária de baixo nível técnico e destruidora dos recursos naturais.

Esse estudo gerou uma resposta quase imediata do Grupo de Trabalho sobre Florestas do Fórum Brasileiro de ONGs e Movimentos Sociais para o Meio Ambiente e Desenvolvimento (FBOMS), num documento elaborado em conjunto com o ISA, intitulado "Relação entre cultivo de soja e desmatamento: compreendendo a dinâmica".

A tese central do estudo é que a expansão da produção de soja está causando um grave desmatamento por meio da dinâmica de derrubada da floresta, implantação da pecuária e transformação posterior da área em agricultura mecanizada.

Esse processo especulativo leva à expansão da fronteira agrícola. Com a crescente modernização da produção, muitos trabalhadores ficam excluídos desses processos, mas também tendem a serem deslocados para áreas marginais, onde contribuem para a abertura de novas fronteiras móveis ou expandem o alcance daquelas existentes.

Uma das consequiências do processo de expansão da fronteira agrícola na região Centro-oeste e Norte é a concentração fundiária, de renda e dos sistemas produtivos grandes fazendas de gado e monoculturas mecanizadas. É o caso da soja, com a subordinação dos padrões culturais e produtivos das comunidades locais e regionais ao padrão dos novos atores sociais, de modo geral imigrantes de outras regiões, com acesso a capital e tecnologia.

Os investimentos em infra-estrutura na região hidrovias, portos, armazéns e estradas têm incentivado o desmatamento. Cerca de $85 \%$ do desmatamento ocorre a cinqüenta 
quilômetros de alguma estrada. Segundo o mesmo estudo, a soja é o grão que emprega menos trabalhadores por área.

A análise parcial de fatores limitantes e estímulos para a futura definição de cenários de expansão da soja na região mostrou que os principais corredores disponíveis para o escoamento Porto Velho/ Itacoatiara e Porto de Itaqui tornam grandes áreas ao longo de rodovias e estradas vicinais suscetíveis à conversão à cultura de soja. A zona de influência da infra-estrutura é definida em função da relação custo-dificuldade de acesso e do retorno econômico da atividade (ISA, 2007).

Uma área de cem quilômetros em torno das estradas apresenta as maiores extensões de áreas já desmatadas, porém sem uso atual para a soja, no norte de Mato Grosso, região central de Rondônia, leste do Pará, norte de Tocantins e sul do Maranhão. Na mesma zona de influência, as áreas de floresta mais suscetíveis ao desmatamento são as de transição entre o cerrado e a floresta, localizadas principalmente no sul de Rondônia, leste e centrooeste de Mato Grosso (ISA, 2007).

O estudo do FBOMS apresenta a tese de que a soja está sendo plantada em antigas regiões de pecuária. Em todas as etapas do processo de desmatamento, os direitos de propriedade são assegurados com a ocupação física da terra, presença que é muito mais importante do que qualquer documento de posse, incentivando a ação de grileiros ou posseiros.

No entanto, como conseqüência desse processo, a pecuária está expandindo a fronteira agrícola. A partir de análises estatísticas, concluiu-se que as taxas de desmatamento são positivamente correlacionadas (50\%) com o incremento do cultivo de soja, e essa correlação é perspectivas dos extremamente significativa do ponto de vista estatístico (mais de $99 \%$ de probabilidade).

A análise da correlação entre a expansão da soja e as taxas de desmatamento em escala municipal mostram que existe uma relação indireta entre os dois fenômenos e indicam que a soja é um dos fatores do desmatamento, mas não o único. Há indícios de que a sua expansão direciona o desmatamento para novas áreas pioneiras e desloca a pecuária para outras áreas.

Além disso, cenários futuros apontam um aumento da expansão da cultura em função da disponibilidade de terra e presença de infra-estrutura disponível. Há elementos que indicam que a soja desloca a pecuária para novas áreas, com provável efeito de 
desmatamento adicional. Isso pode ser observado pelo fenômeno da redução do rebanho bovino nos principais municípios produtores de soja, porém com aumento de rebanho nas regiões limítrofes, com destaque, no caso de Mato Grosso, para os municípios das regiões de fronteira móvel. Nesse estado, particularmente, foram analisadas diversas variáveis para a quantificação desse processo.

Nas áreas de expansão da soja, é a lucratividade da pecuária e a posterior transformação ou venda da terra para a agricultura intensiva que sinaliza, tanto para os agentes iniciais quanto para os próprios pecuaristas, que o desmatamento e a conversão das florestas em pastagens é rentável. Se não existissem lucros, não haveria interesse pela apropriação ou compra de terras convertidas, e os desmatamentos certamente teriam um ritmo muito menos intenso (ISA, 2007).

Essa expansão da cultura de soja na região pode causar impactos irreversíveis, tanto sócio como ambientalmente. A figura 4.3 mostra o solo descampado em função da cultura de soja em áreas da Amazônia:

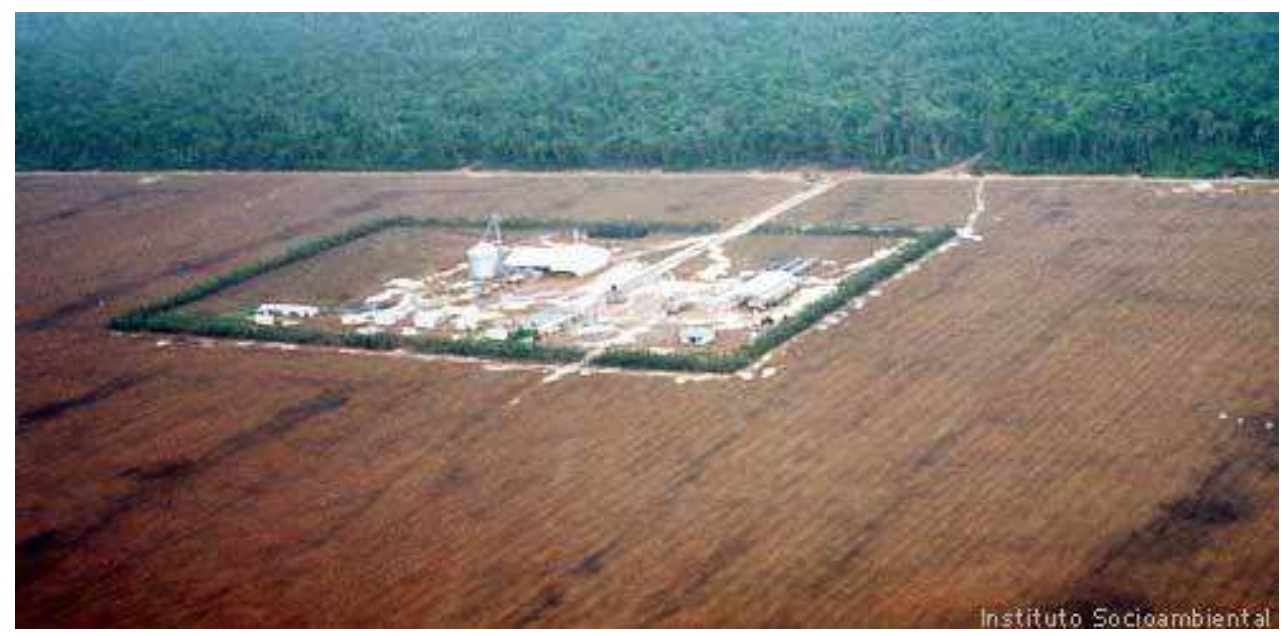

Fonte: http://www.socioambiental.org/esp/soja.br

Figura 4.3: Evolução da plantação de soja 


\section{ESTUDO DE CASO: A REGIÃO DO MUNICÍPIO DE SÃO JOSÉ DO XINGU}

\subsection{Histórico de São José do Xingu (MT) e arredores}

São José do Xingu está localizado na região Centro-Oeste do Brasil e na região nordeste do estado de Mato Grosso. Faz limites ao leste com o município de São Félix do Araguaia e Canabrava do Norte, a oeste com o município de Santa Cruz Do Xingu e Peixoto de Azevedo, ao norte com o município de Porto Alegre do Norte e Confresa e ao sul com o município de Marcelândia. A figura 5.1 mostra uma vista aérea do município.

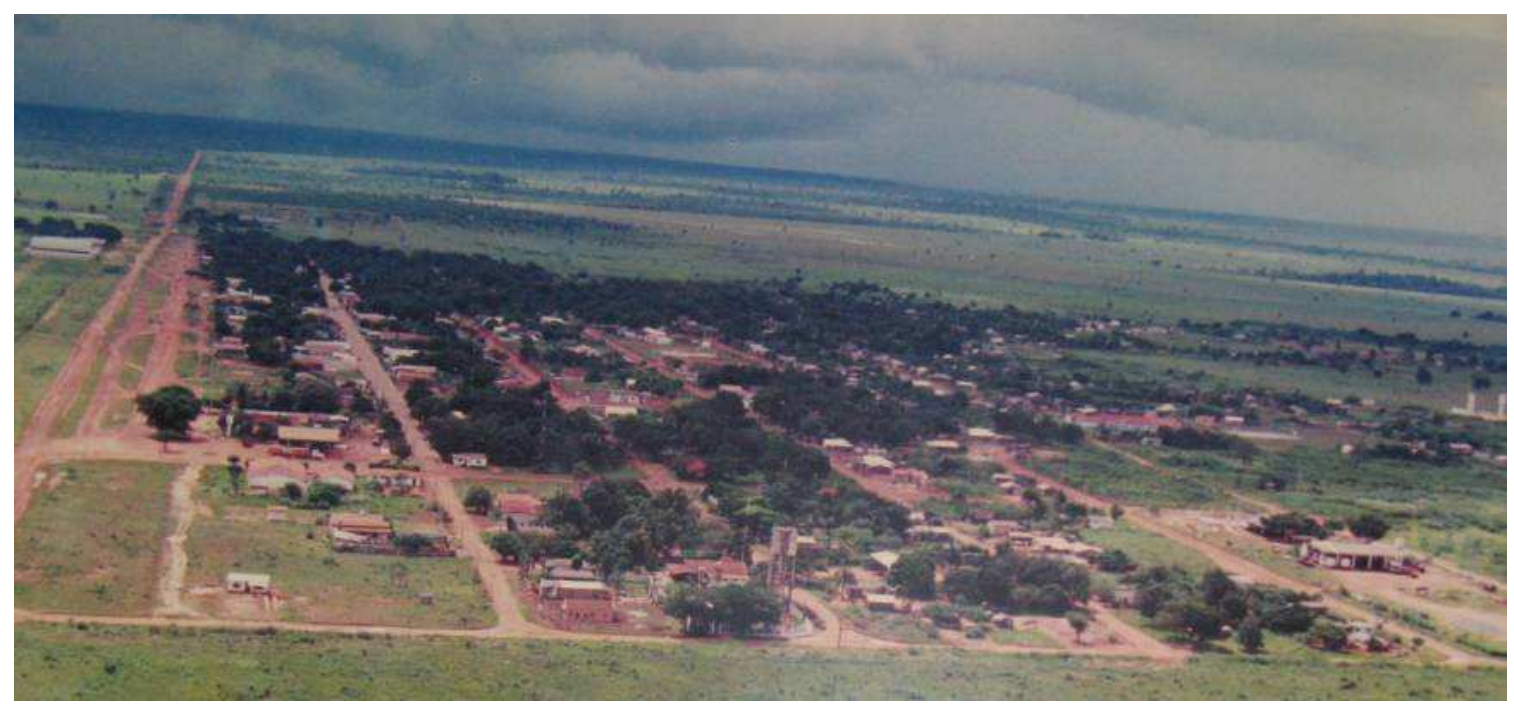

Fonte: Prefeitura municipal de São José do Xingu, 1998

Figura 5.1: vista aérea de São José do Xingu

A área de superfície do município é de $8.010 \mathrm{~km}^{2}$ e a distância da capital matogrossense Cuiabá é de $970 \mathrm{~km}$. A população está atingindo cerca de 6.700 habitantes, sendo cerca de 3.200 eleitores (Empaer, 2009).

O município de São José do Xingu tem clima equatorial, predominantemente quente e úmido com temperaturas elevadas na maior parte do ano, média anual de $24^{\circ} \mathrm{C}$ e máximas de variação térmica entre $40^{\circ} \mathrm{C}$ e $19^{\circ} \mathrm{C}$. A precipitação pluviométrica varia entre $1850 \mathrm{a}$ $2300 \mathrm{~mm} / \mathrm{ano}$, com época seca somente durante 3 meses: junho, julho e agosto, favorecendo a presença da vegetação típica da floresta amazônica.

Os solos predominantes são podzólicos vermelho amarelo, com textura variando de arenosa, média e argilosa. A topografia é plana o que propicia o plantio de lavouras e demais práticas agropecuárias. A hidrografia é perene, com muitos rios afluentes dos 
principais rios das sub-bacias pertencentes à Bacia Amazônica, como Bacia do rio Comandante, do rio Fontoura ou do rio Xingu.

A localização do município se dá a $300 \mathrm{~km}$ de distância de um centro urbano de maior importância. Durante muito tempo manteve-se fora dos mapas por apresentar pouca expressividade econômica. Está encravada no eixo da BR 080, que ainda não é pavimentada, gerando transtornos para o acesso a cidade (Santos, 2008).

A maior parte das cidades brasileiras cresceu e desenvolveu-se espontaneamente, a partir da chegada de pessoas e formação de núcleos urbanos. São José do Xingu nasceu dessa mesma forma como uma invasão de grupos sem terra.

A colonização do núcleo que deu origem ao município de São José do Xingu deu-se a partir da fixação da nova fronteira agrícola brasileira, no estado de Mato Grosso, na década de 70. Os incentivos fiscais permitiram que novas áreas fossem povoadas, aumentando o contingente populacional estadual e criando novas unidades de colonização. O município foi, então, fundado em 1974.

O município desenvolveu-se a partir da abertura de pastos para pecuária bovina sobre as áreas florestadas, ainda sendo a atual base da economia local. Nos últimos anos tem sido alvo da expansão da produção de grãos, principalmente soja e milho para atender as empresas locais. A Agroindústria é movimentada por duas indústrias de secagem e armazenamento de grãos, a Cargil e Canic, além de um entreposto de recebimento de leite do grupo Piracanjuba (Empaer, 2009).

De acordo com fontes locais, a Fazenda Reunidas foi a primeira a instalar-se no local, importante pólo de atração para população já que criava empregos na formação da cidade. Vieram de Barra do Garça (MT), São Félix do Araguaia (MT) e Goiás.

Mas núcleo original de povoamento surgiu na Fazenda Bang Bang, do Sr. Maurin, de Goiânia, que tinha este nome em função dos inúmeros casos resolvidos à bala. Consta na história oral pelos mais antigos moradores que qualquer "pendenga" ${ }^{10}$ se resolvia em tiros. Lembrava os filmes de "Bang-bang" - daí o nome que se deu ao lugar: Povoado do Bang Bang (Empaer, 2009).

Com o passar dos tempos a comunidade incorporou o nome do santo, ficando São José do Bang Bang. Não ficava bem o nome do santo ao lado de lembranças desagradáveis

\footnotetext{
${ }^{10}$ Assunto a resolver, pendência.
} 
que a palavra "Bang-bang" sugeria. Era um núcleo de povoamento com sede no município de Luciara. (Empaer, 2009). A figura 5.2 mostra um centro importante da cidade.

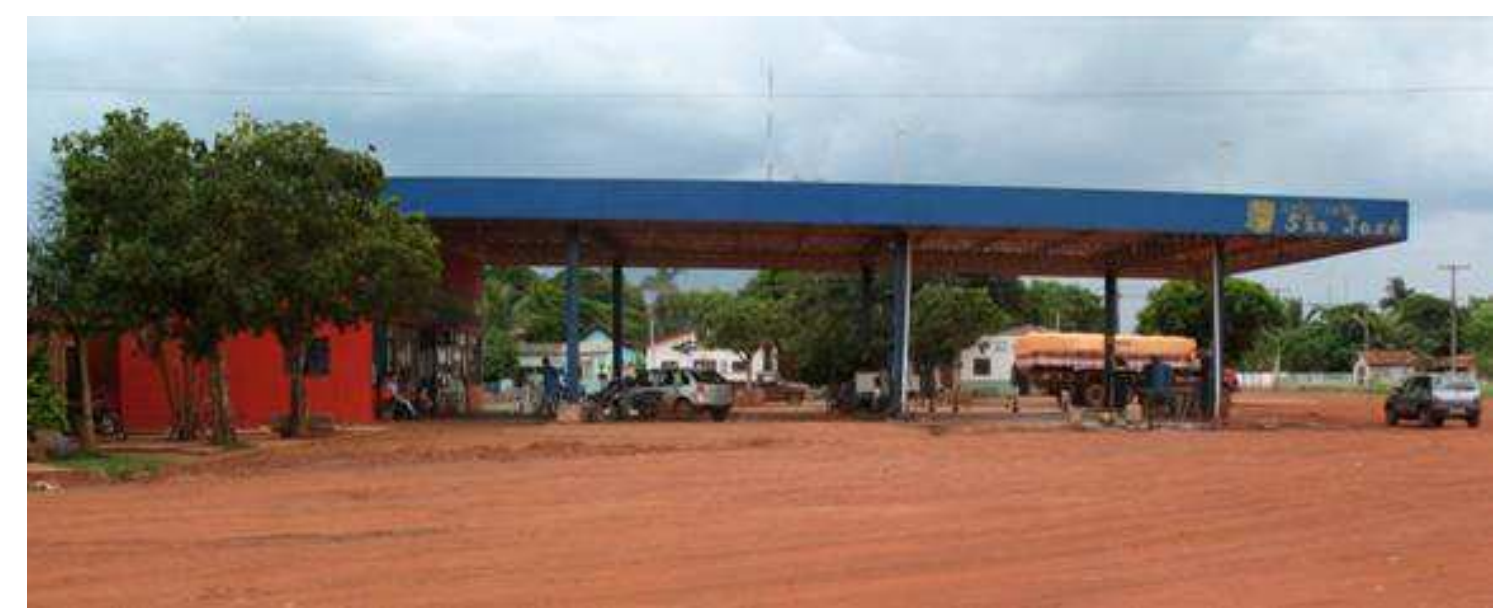

Fonte: Pesquisa de campo, 24/09/2009

Figura 5.2: Município de São José do Xingu

No início da década de 90, optou-se pela alteração da denominação. Em 20 de dezembro de 1991, através da Lei Estadual no 5.904, foi criado o município de São José do Xingu. A comunidade optou por deixar o nome do santo protetor no nome da localidade: São José; e acrescentar "do Xingu", em homenagem ao Rio Xingu, que passa a $42 \mathrm{~km}$ da sede municipal e ao Parque Nacional do Xingu, que faz divisa com o município.

Xingu é o nome de um ente mítico no Brasil. Já o era para muitos povos indígenas que viviam nas margens do grande rio e seus afluentes há séculos, talvez mais de mil anos. O rio é afluente da margem direita do Amazonas e o nome traz associação direta com os índios da região, que ainda preservam hábitos indígenas fortes (Sevá $\mathrm{F}^{\circ}$, 2005).

Os irmãos Villas-Boas, Leonardo, Cláudio e Orlando, indigenistas respeitados, funcionários do antigo SPI - Serviço de Proteção ao Índio (posteriormente absorvido pela FUNAI - Fundação Nacional do Índio) obtiveram do governo federal que decretasse, na década de 1960, a demarcação de um conjunto de terras indígenas, o PIX - Parque Indígena do Xingu, no quadrante nordeste do território de Mato Grosso, atualmente com cerca de 25 $\mathrm{km}^{2}$ de extensão (Sevá $\left.\mathrm{F}^{\circ}, 2005\right)$.

Mesmo com terras demarcadas, os limites que supostamente estariam protegidos são alvos de ação de invasores, garimpeiros, madeireiros, grandes grileiros entre outros. Outro 
meio de exploração ocorre quando caciques são postos a negociar acordos e compensações pelo uso das riquezas localizadas perto de suas aldeias, no interior de suas terras legalizadas (Sevá $\left.\mathrm{F}^{\circ}, 2005\right)$.

São José do Xingu limita o PIX ao norte. Ali o perímetro Indígena é limitado por um ângulo quase reto contido pelo traçado da rodovia BR 080/ MT 332. O Parque Nacional do Xingu cobre cerca de $30 \%$ da área do município, com aproximadamente 260.mil hectares e 14 etnias indígenas (Empaer, 2009; Sevá Fº 2005).

Diferentemente da reserva, nas áreas de fazendas há várias partes degradadas, devido ao processo de ocupação do território que sempre estimulou a substituição da floresta pela atividade agropecuária. Áreas de APP's (áreas de preservação permanente) e áreas de reserva legal foram derrubadas, havendo vários problemas com assoreamento e poluição de nascentes de rios, acarretado pela expansão da pecuária, por plantio de lavoura e práticas agrícolas não adequadas (Empaer, 2009).

O município de São José do Xingu abrange um distrito chamado Santo Antonio do Fontoura com cerca de 1500 habitantes, e existem três comunidades formadas por assentamentos do Incra ocupando $7,41 \%$ da área do município com aproximadamente 59.250 hectares: Yamin com 90 familias; Aymoré com 70 familias; e Santo Antonio do Fontoura I, com 340 famílias (Empaer, 2009).

O perfil fundiário é representado por grandes fazendas que representam cerca de 62,5\% da área do município, com aproximadamente 481 wmil hectares. Conforme levantamento feito junto ao sindicato existe cerca de 120 propriedades de porte grande no município de São José do Xingu. No Indea, existem 326 propriedades com movimentação, isto é, que criam bovinos, mas no município existe cerca de 300 produtores assentados pelo Incra apesar dos 540 lotes da reforma agrária, distribuídos nos três assentamentos. Seguem os Projetos de Assentamento (PA) da região (Indea, 2009).

- PA Yamin: localiza-se a $5 \mathrm{~km}$ da sede do município e é servido pela MT 322 e por estradas vicinais do Incra. Configura-se como uma PA emancipada com $80 \%$ das áreas tituladas, 99 lotes e todas as famílias estão bem estruturadas. No período chuvoso a logística é comprometida devido às más condições das estradas. Este PA recebe assistência técnica da Empaer (Empresa Mato-grossense de Pesquisa, Assistência e Extensão Rural S/A, - MT) em conjunto com a Secretaria Municipal 
da Agricultura e o ISA (Instituto Sócio-ambiental ), que tem um projeto de recuperação de nascentes e matas ciliares.

- PA Aymoré: está localizado a $2 \mathrm{~km}$ da sede do município e tem melhor serviço de estradas vicinais feitas pelo Incra e pela MT 322. O PA está emancipado com $80 \%$ das áreas tituladas e 79 lotes, onde somente a Empaer - MT prestou assistência técnica neste PA.

- PA Santo Antonio do Fontoura I: é um assentamento mais recente criado em 1999 com 340 famílias. Localiza-se a $110 \mathrm{~km}$ da sede do município, na divisa com o município de Confresa com difícil acesso no período das chuvas. Ainda está em fase de estruturação, mas $100 \%$ dos agricultores receberam crédito Pronaf (Programa Nacional de Fortalecimento da Agricultura Familiar) para implantação e 50\% já receberam crédito moradia. Precisa de melhoria e manutenção das estradas vicinais construídas pelo Incra nos anos de 2001/2002. É um PA atendido pela Empaer MT.

A força de trabalho predominante nas áreas dos assentamentos é a familiar e o uso de tecnologia é baixo. Já nas fazendas, a mão de obra utilizada é a contratada com aplicação de técnicas tradicionais e modernas de produção.

No município de São José do Xingu é possível encontrar pontos de comércio e serviços simples na sede municipal, além de

- Instituições Públicas de atendimento prioritário do Estado, Município e Federação: Policias Militar e Civil na área de segurança pública;

- Hospital conveniado com o SUS (Sistema Único de Saúde) e com a Secretaria Municipal de Saúde e a Funasa, que atende aos indígenas ocupantes do Parque Nacional do Xingu - MT, na área da saúde;

- Escolas municipais na sede e no distrito de Santo Antonio do Fontoura, uma escola estadual na sede e a Unitins com curso de nível superior de formação a distância, na área da educação; e

○ Órgãos de Defesa e Extensão Rural como o Indea (Instituto de Defesa Agropecuária) e Empaer-MT (Empresa Matogrossense de Pesquisa, Asssistência e Extensão Rural S/A, e a Famato (Federação da Agricultura e Pecuária do Estado do Mato Grosso) representada pelo sindicato rural. 
Os serviços especializados prestados no município se referem a um cartório de $2^{\circ}$ oficio e escritórios de contabilidade que atendem o comércio local e as fazendas da região. Há ainda um viveiro de mudas municipal hoje funcionando em parceria com o ISA e uma empresa de georreferenciamento e levantamento topográfico com sede em São José do Xingu-MT.

O abastecimento energético é feito através do Sistema Interligado de Transmissão a partir da energia hidrelétrica gerada na região. O fornecimento é feito através da rede CEMAT, atendendo $100 \%$ da zona urbana e $85 \%$ das propriedades rurais do município.

A partir de 2002, os fazendeiros de São José do Xingu estão substituindo os pastos degradados por plantação de grãos, como é o caso da soja. Desde então, a cidade torna-se uma parte desse sistema moderno de plantio e venda de soja para as empresas locais, e conseqüentemente, para o exterior. (Santos, 2008).

De 2002 a 2005 São José do Xingu passou por uma mudança econômica. Houve forte queda dos preços da arroba do gado e sensibilização do setor, com o surgimento da "febre aftosa" em Mato Grosso do Sul, o que gerou uma crise no setor. A dificuldade propiciou a procura de novas áreas para diversificação da produção, investindo em áreas paralelas (pecuária x agricultura) buscando agregar valor à produção primária.

Quando a Cargill chegou à cidade, os agricultores foram ainda mais estimulados para o plantio. Pesquisas começaram a ser realizadas com o propósito de dar sustentabilidade à produção, utilizando alta tecnologia, diversificando cultivo, o aumento da produtividade e o crescimento da concorrência. Buscava-se viabilidade de transporte para atingir novos mercados, agregando valor através de processos agro-industriais.

Com tudo isso, os empresários decidiram apostar no plantio de várias culturas de terra para aumentar a renda, gerar empregos e aumentar a economia da cidade. Desde 2002, cerca de 365 fazendas de São José do Xingu e arredores iniciaram o plantio de grãos como arroz, milho, sorgo e soja. Vários coeficientes foram determinantes para o desenvolvimento progressivo da agricultura, como as condições geográficas (solo, clima) associada à disponibilidade de terras com topografia plana e boas condições para mecanização agrícola.

A figura 5.3 demonstra uma interface entre a floresta Amazônica e área de plantio de soja. 


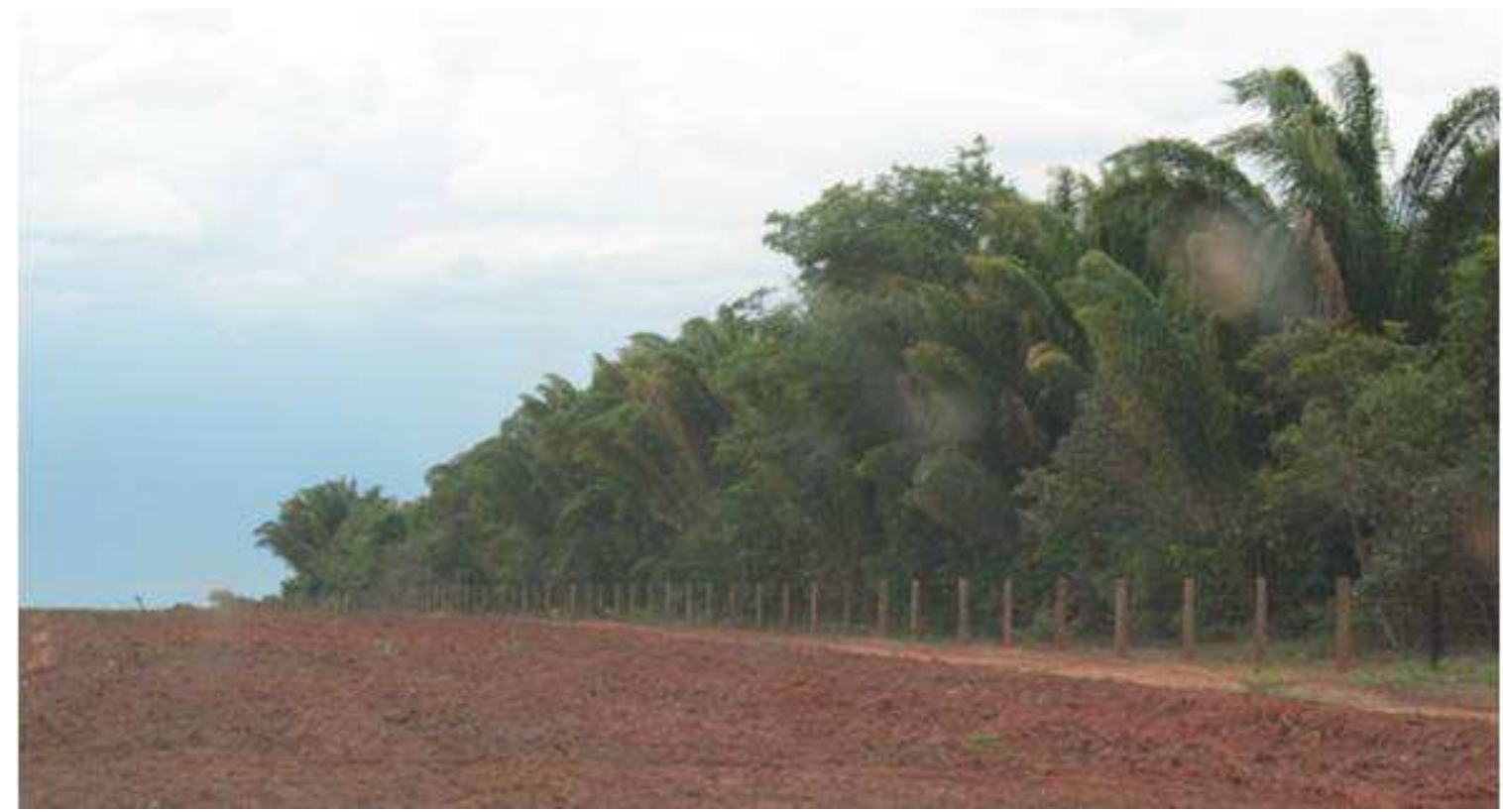

Fonte: Pesquisa de campo, 26/09/2009.

Figura 5.3: Interface entre área de preparo de solo para

Plantio de soja e Floresta Amazônica.

Segundo a Secretaria Municipal da Agricultura (2009), a cidade iniciou o plantio de grãos em 2002/2003, com uma área de 16.800 hectares sendo estável em 2003/2004. A principal cultura era de soja em uma área de 6.500 hectares e 19.500 toneladas de produção. O milho representava 1.000 hectares e 4.800 ton de produção; sorgo 300 hectares e uma produção de cerca 360 ton e o arroz 9.000 hectares e com 3.000 ton de produção. Importante ressaltar que sorgo e milho fazem parte das culturas de rotação nas áreas de plantio de soja.

A tabela 5.1 demonstra as principais atividades econômicas do município. 
Tabela 5.1-Principais Atividades Econômicas em São José do Xingu - MT

Agricultura (2006)

Pecuária (2006)

\begin{tabular}{|c|c|}
\hline Cultura & Produção (toneladas) \\
\hline Soja & 21.600 \\
\hline Arroz & 6.000 \\
\hline Mandioca & 4.800 \\
\hline Milho & 4.200 \\
\hline Banana & 730 \\
\hline Borracha & 126 \\
\hline
\end{tabular}

\begin{tabular}{|c|c|}
\hline Rebanho & quantidade \\
\hline Bovino & 357.789 \\
\hline Aves & 23.547 \\
\hline Suínos & 4.764 \\
\hline Equinos & 2.323 \\
\hline Ovinos & 519 \\
\hline
\end{tabular}

Fonte: Santos, 2008

Fonte: Santos, 2008.

Área Plantada com culturas de Sorgo e Soja em São José do Xingu

\begin{tabular}{|c|c|c|c|c|}
\hline \multirow{2}{*}{ Ano } & \multicolumn{2}{|c|}{ Sorgo } & \multicolumn{2}{c|}{ Soja } \\
\cline { 2 - 5 } & Área (ha) & Produção (ton) & Área (ha) & Produção (ton) \\
\hline 2001 & 300 & & 6500 & 19500 \\
\hline 2002 & 300 & 360 & 6500 & 19500 \\
\hline 2003 & 300 & 360 & 6500 & 19500 \\
\hline 2004 & 600 & 720 & 2000 & 6000 \\
\hline 2005 & 500 & 600 & 2000 & 6000 \\
\hline
\end{tabular}

Fonte: Santos, 2008.

De acordo com agricultores locais, o plantio de grãos era motivado pela ação na recuperação do solo devido à erosão e acidificação ocasionada pelas más técnicas pecuárias empregadas. Em alguns anos, com o uso de fertilizantes, adubação e o plantio de culturas de soja e arroz, foi possível a recuperação do solo, onde nem a grama brotava mais.

Também, nos anos iniciais do plantio houve incentivos governamentais com financiamentos do Propasto (Programa de Recuperação de Pastagens Degradadas) e Prosolo (Programa de Incentivo ao Uso de Corretivos de Solo) (Nogueira Netto, 2004).

Entretanto, houve uma queda de preço expressiva no caso do arroz, que passou de $\mathrm{R} \$ 37,00$ por saca no primeiro ano para custar $\mathrm{R} \$ 7,00$. Já no caso da soja, o retorno é rápido, em seis meses, com uma boa colheita paga-se os investimentos do plantio, mas oscilam com os preços internacionais das commodities. No caso de bovinos, o retorno é mais lento e menor, porém mais seguro, pois o capital flutuante é menor.

Agricultura é um bom empreendimento para o produtor e para a cidade, já que colabora com a geração de empregos. Porém, não há incentivos governamentais para o plantio Para viabilizar o plantio foi necessário utilizar corretivos no solo, como calcário, 
fosfatos, fertilizantes, já que se encontrava degradado devido às técnicas pecuárias mal empregadas. E os subsídios e incentivos governamentais não ocorreram mais.

Ainda, órgãos ambientais como a SEMA - Secretaria Estadual do Meio Ambiente o Ibama, e o ISA, iniciaram projetos na região para reconstrução das áreas degradadas pela pecuária, e atualmente, a soja é plantada como produto para reconstituir os nutrientes do solo e as áreas das cabeceiras dos rios - APP's - que foram amplamente desmatadas. Na pecuária, tais áreas não foram poupadas de desmate, pois eram abertas para chegada do gado aos açudes. Isso gerou seca ou migração de algumas nascentes, piorando ainda mais a drenagem dos solos.

Entretanto, observa-se empenho das fazendas em reconstituir a mata nativa dessas APP's. Há 5 anos o ISA tem projetos na cabeceiras dos rios da bacia do rio Xingu que visam a recuperação dessas áreas com plantios alternados de espécies que possa reconstruir a mata com o semblante mais próximo do nativo. A fazenda Bang-bang já faz parte do projeto e tem áreas muito próximas de recuperação total.

Na figura 5.4 observa-se uma área em reconstituição de mata da fazenda Bang-bang.

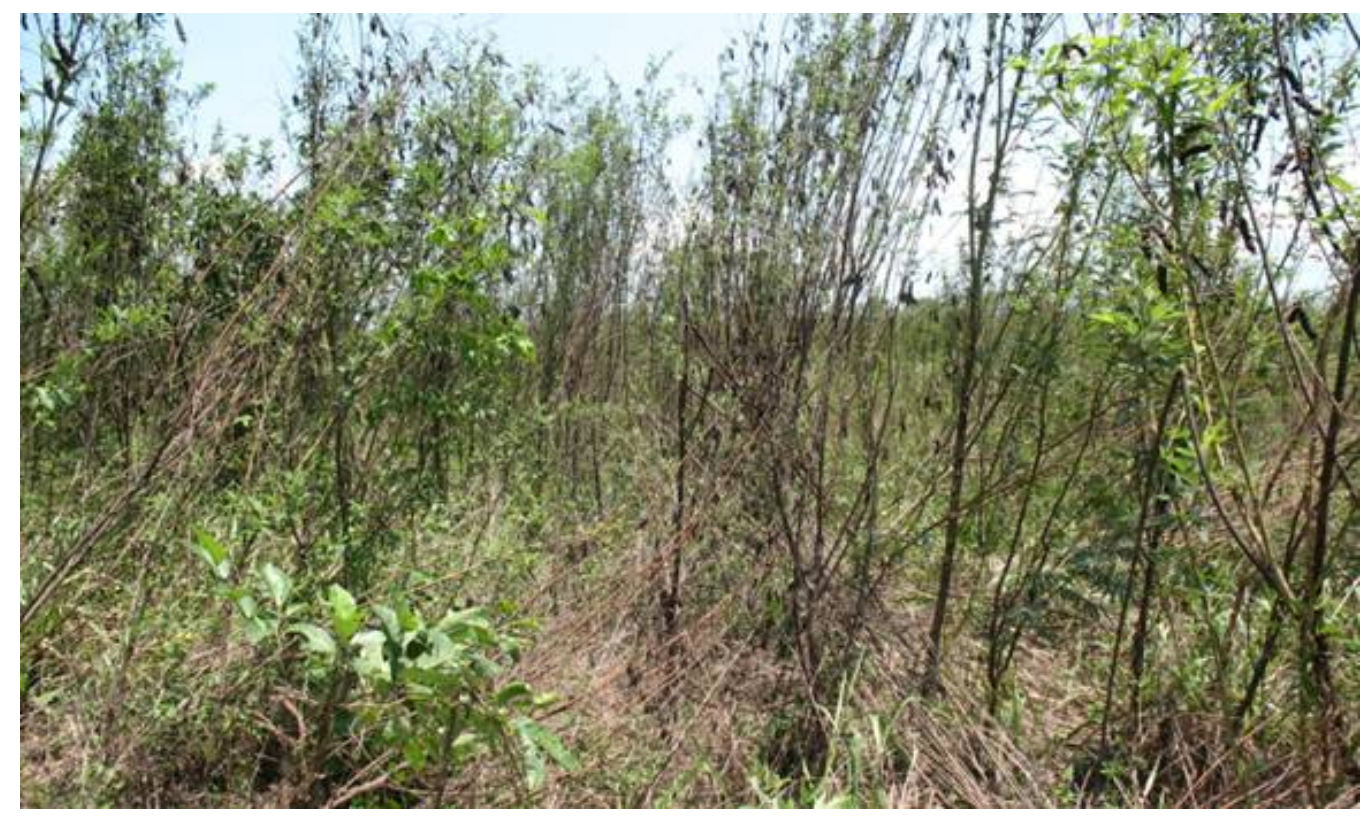

Fonte: Pesquisa de campo, 26/09/2009.

Figura 5.4: Área de APP em reconstituição de mata nas cabeceiras dos rios.

Ainda, as técnicas empregadas pelos fazendeiros e administradores procuram minimizar os impactos da agricultura sojeira. A rotação de culturas é uma delas, com 
plantios alternados de milho e sorgo ou milhete nas épocas de colheita da soja. O milhete ou sorgo são utilizados somente para agregar palha ao terreno e propiciar adubo natural ao plantio que se segue, que é o de soja. Como referido anteriormente, fertilizantes como calcários e fosfatos são amplamente utilizados para correção da acidez do solo.

Na figura 5.5 há imagem de cultura de soja de abril de 2007 da fazenda Barra do Dia.

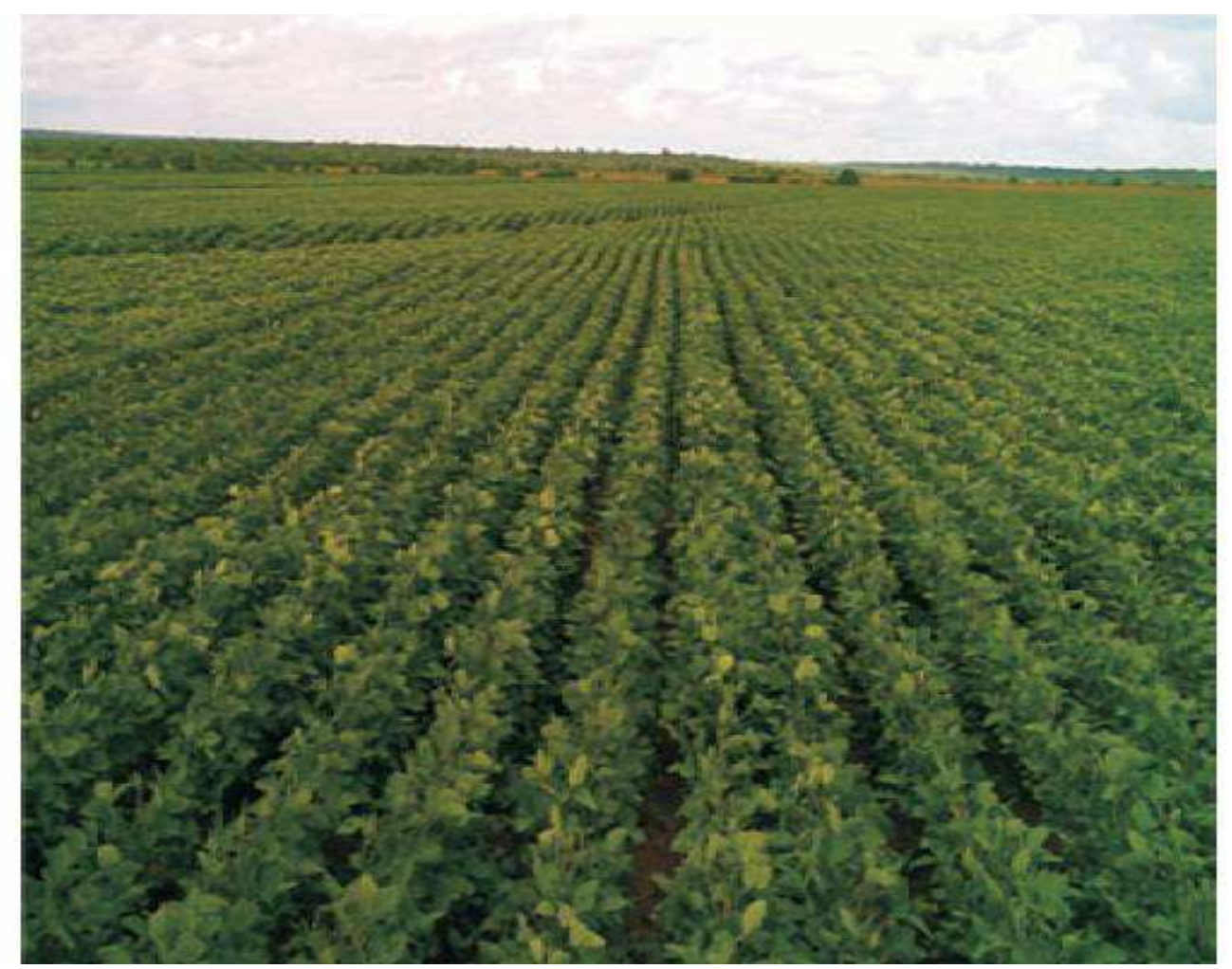

Fonte: Santos, 2008.

Figura 5.5- Cultura de soja em abril de 2007, na fazenda Barra do Dia

Diante o exposto, a área de estudo escolhida São José do Xingu (MT), tem grande potencial de crescimento agrícola com base na soja. Ainda, representa um local que, ao longo dos anos, passou a se inserir no arco de deflorestamento, ou seja, área de fronteira agrícola limitante com a Floresta Amazônica. 


\subsection{Pesquisa de campo}

Essa pesquisa foi realizada entre os dias 20 e 29 de setembro de 2009, na região norte do Mato Grosso. Seu objetivo foi verificar in loco as informações obtidas na interpretação das imagens de satélite e analisar a região como área produtora de soja para biodiesel e o desmatamento associado a essa cultura.

Para isso, foi selecionado um trajeto a ser percorrido a fim de avaliar as consequiências ambientais e sociais na área de estudo. $\mathrm{O}$ que orientou os caminhos realizados no campo foi a localização das usinas de biodiesel, até a chegada no destino final: o município de São José do Xingu, área da interpretação das imagens de satélites.

No período mencionado da realização desta pesquisa de campo, foram visitadas usinas de biodiesel e plantios de soja da região, assim como foram obtidas informações históricas e recentes com entidades públicas e privadas.

A pesquisa de campo iniciou-se no município de Sorriso, passando por Feliz Natal, Sinop e Colíder até São José do Xingu. Nesses pontos usinas de biodiesel e fazendas com cultura de soja foram visitadas e seus representantes entrevistados.

O Mapa 1 demonstra a localização geral da área de estudo e das imagens de satélite analisada. A figura 5.7 demonstra-se a área coberta pelo trabalho de campo com os pontos indicativos de visita, de 1 a 5 , que serão descritos posteriormente. 

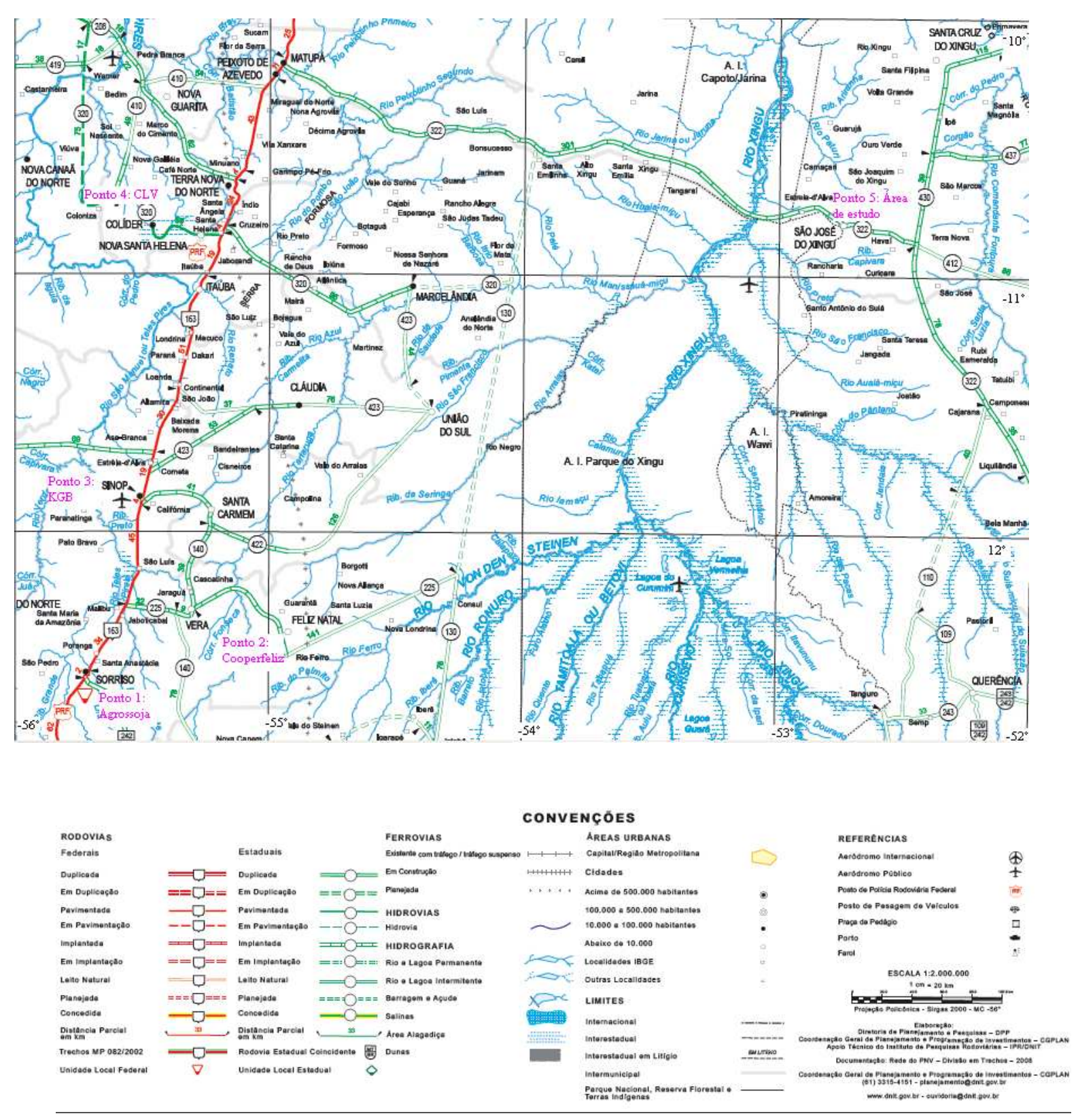

Fonte: DNIT, 2009.

Figura 5.6 - Área de visita a campo 
A área de estudo refere-se ao norte do Mato Grosso. As imagens de satélite analisadas são da região de São José do Xingu, extremo nordeste matogrossense. Para analisar o processo de ocupação histórica da região e uso do solo foram percorridas áreas consolidadas de plantio de soja na expansão ocorrida nas décadas de 80 e 90, além de verificar as usinas de biodiesel presentes no entorno.

A pesquisa de campo foi dividida em pontos de visita de 1 a 5 que representam, respectivamente, os municípios de Sorriso, Feliz Natal, Sinop, Colíder e, como principal objeto de estudo São José do Xingu.

Os pontos de 1 a 4 serão relatados nos capítulos 5.2.1 a 5.2.4 descrevendo um pouco do seu histórico de ocupação, atividades econômicas preponderantes, as usinas de biodiesel visitadas e as informações obtidas. Entretanto, São José do Xingu já foi descrito no capítulo 5.1 relatando seu histórico. Mas os dados específicos das fazendas da região produtoras de soja serão trabalhados no capítulo 5.2.5. 


\subsubsection{Ponto 1 - Município de Sorriso (MT) - usina Agrossoja}

O primeiro ponto de visita foi o município de Sorriso, onde encontra-se a usina Agrossoja. O município de Sorriso está situado na região norte do Estado, no km 742 da rodovia BR 163, Cuiabá-Santarém, a $412 \mathrm{~km}$ da Capital, Cuiabá. A sua fundação deu-se através de um projeto de colonização privada, com a maioria absoluta de sua população constituída de migrantes provenientes da região sul do país, principalmente dos estados do Rio Grande do Sul, Paraná e Santa Catarina.

Em 26 de dezembro de 1980, a pequena agrovila encravada em pleno sertão Matogrossense, foi elevada a categoria de Distrito, pertencente ao Município de Nobres. Em 20 de março de 1982, foi instalada a Sub-Prefeitura no Distrito de Sorriso. A Assembléia Legislativa do Estado do Mato Grosso aprovou em 13 de maio de 1986, e o governador Júlio Campos, através da lei 5.002/86 elevou, então, o Distrito de Sorriso á categoria de Município, desmembrado dos Municípios de Nobres, Sinop, e Diamantino, com uma área de 10.480 km². (Tnbrasil, 2008).

A economia de Sorriso tem sua principal fonte geradora de renda na agricultura mecanizada (arroz, soja, milho e agora está se tornando um grande produtor de algodão), sendo o maior produtor de grãos do Brasil, representando $2 \%$ da produção nacional e 15,5\% da produção estadual. É o município com maior área plantada de soja do estado, chegando a 600 mil hectares.

A Agrossoja, empresa privada localizada no Município de Sorriso, foi criada em 1999 com o processamento de óleo de soja e, a partir de 2007, passou a produzir biodiesel. É a única usina do município que faz a extração do óleo e beneficiamento da soja, existindo outras usinas em outros municípios ou somente armazéns geralmente de empresas transnacionais para estocagem, como Cargil, Bunge, ADM, Maggi.

Essas, por sua vez, encaminham aos locais de processamento que se estabeleceram em Cuiabá, Primavera, Lucas do Rio Verde, entre outras localidades. Os grãos de soja utilizados como matéria-prima são fornecidos por fazendas que estão localizadas nos arredores, nos municípios de Sorriso e Boa Esperança.

A usina utiliza como principal matéria-prima para o biodiesel a soja. Importante ressaltar que as tecnologias empregadas em cada usina diferem-se, o que viabiliza ou não certas produções e uso de matérias-primas. Testes foram realizados na empresa para utilização de 
sebo bovino como ácido graxo, porém, a tecnologia empregada pela usina inviabilizou sua produção. Essa matéria-prima só foi viável com mistura adequada de proporções de outras fontes, o que muitas vezes compromete a viabilidade econômica, devido ao custo que o sebo bovino alcançou no mercado após sua vocação de uso para produção de biodiesel.

Quando os valores abaixam, é possível utilizá-lo em proporções pequenas (cerca de $10 \%$ ), pois o biodiesel com $100 \%$ de sebo bovino encontra obstáculos qualitativos, não cumprindo as exigências solicitadas pela ANP. Na usina, a rota tecnológica utilizada é a metílica, tendo o metanol importado e o metilato de sódio pronto como catalisadores.

Inicialmente, a produção de soja era comercializada ao exterior, mas com o aprimoramento das técnicas e o processamento dos grãos, o óleo de soja passou a ser o principal produto da usina, tendo como destino o abastecimento do mercado interno. A capacidade de processamento da usina é 1000 ton/dia de grãos para produção de óleo e farelo, sendo utilizados para produção de biodiesel $25 \%$ desse total. Atualmente, a capacidade de geração de biodiesel da usina é de 80 mil 1/dia, com pretensão de produção de 120 mil l/dia.

A ANP possui um processo para licitação caracterizado como "lento, burocrático e complicado, porém necessário" de acordo com Sr. Cássio Graciolli, gerente de produção da usina. Os documentos, as avaliações, os testes, as certificações eram demorados por que a própria ANP readequava as solicitações diante o que a empresa enviava.

Após um projeto e sua execução, ainda cerca de 8 meses foram necessários para testes com o produto final para cumprimento das exigências de qualidade de ANP. Nesse ínterim, foram necessárias algumas alterações no processo, assim como escolher a matéria-prima mais adequada e tentar o uso do etanol (rota etílica) na produção. Apesar disso, a licença levou um ano para ser adquirida. Depois disso, apenas pequenas adaptações foram feitas, sem comprometer a qualidade do produto.

Muitas usinas da região com pequenas produções ( $2 \mathrm{mil}$ 1/dia, por exemplo) desistiram de pedir autorização da ANP devido à burocracia e às exigências documentais, como certificados de processos e outros cumprimentos técnicos. Atualmente, para autorização de ampliação da planta de produção de biodiesel, o processo é mais fácil e menos burocrático.

As vendas do biodiesel são direcionadas à Petrobrás que é obrigada a comprar para o cumprimento da lei na adição de 3\% de biodiesel ao diesel mineral. A Petrobrás realiza leilões onde as empresas participantes têm custos de produção muito próximos, assim preço pago 
geralmente cobre os gastos. No último leilão realizado, em agosto de 2009, a Agrossoja vendeu seu produto a $R$ \$ 2,34/1 a serem entregues em janeiro, fevereiro e março de 2010, embora tenham ocorrido vendas a $\mathrm{R} \$ 2,15 / 1$ por outras usinas. Atualmente, os custos da empresa com a produção estão em torno de $\mathrm{R}$ \$2,20/1, mas são extremamente variáveis.

Essa variação ocorre porque o preço do óleo de soja que oscila no mercado durante o ano, obedecendo aos valores estabelecidos nas commodities. O ônus da Petrobrás despendido na compra do biodiesel é repassado ao consumidor, na proporção da adição do produto ao diesel mineral. Hoje em dia, essa proporção é de $3 \%$ com projeções, a longo prazo, de um aumento de até $8 \%$.

Com a eficácia da legislação e fiscalização ambiental, que cada vez mais tem sido efetiva, a preocupação da usina está acerca em cumprir as exigências legais e ambientais no processo de obtenção da soja, privilegiando sua compra em áreas de agricultura familiar, como exige o Selo Social. No contexto da Agrossoja, o biodiesel de soja que provêem de pequenas propriedades representa cerca de $5 \%$ de sua produção.

O governo repassa somente benefícios fiscais à produção de biodiesel, tais como isenções ou renúncia de parte do ICMS estadual (imposto sobre operações relativas à circulação de mercadorias e sobre prestações de serviços de transporte interestadual e intermunicipal e de comunicação) cedidos pelo Prodeic (Programa de Desenvolvimento Industrial e Comercial de Mato Grosso) ou por meio de financiamentos com pagamentos a longo prazo e juros muito baixos.

No mês de setembro foi possível observar uma paralisação das atividades da usina para produção de biodiesel devido ao excesso de glicerina estocado na usina (aproximadamente 800 toneladas), resultado do processo de produção do biodiesel. Apesar do uso intensivo desse produto nas indústrias química, farmacêutica e de cosméticos e sua queima para geração de calor ou energia em indústrias pesadas, a Agrossoja têm encontrado dificuldades em escoar o volume alto residual do processo.

No futuro, sua comercialização como produto beneficiado poderá atender mercados externos, como a China que teria interesse em sua compra, ou na geração de energia a partir de sua queima na própria usina (podendo representar potencial em cogeração). Mas até então, a glicerina bruta tem se apresentado como um empecilho, pois ainda possui entraves tecnológicos para seu aproveitamento. 
Outro entrave refere-sea localização distante da usina dos centros consumidores (regiões sul e sudeste). Até agora, a Petrobrás é responsável pelo frete do biodiesel comprado nos leilões, ou seja, ela vai até usina para sua retirada. Apesar da soja na região ser adquirida a preços baixos, os gastos com transporte encarecem a produção. No caso do metanol, além de ser importado seu frete representa cerca de $10 \%$ do custo envolvido na produção.

Ainda, com a tendência que se aproxima para a venda ao mercado aberto, os custos com a logística serão repassados ao produtor, o que pode inviabilizar sua venda. Por isso é provável que um mercado regional deverá surgir para absorção dessa produção. Muitas vezes é mais rentável vender apenas o óleo de soja que é processado na indústria e não o biodiesel que envolve adição de outras matérias primas para reação, encarecendo o processo. 


\subsubsection{Ponto 2 - Município de Feliz Natal (MT) - Usina Cooperfeliz}

O município de Feliz Natal está localizado a $530 \mathrm{~km}$ ao norte da capital Cuiabá, estando a uma altitude de 370 metros. Sua população estimada em 2008 era de 10.013 habitantes, a maior parte proveniente de estados do Sul. A emancipação do município ocorreu em 1995, tendo sua área territorial inteiramente desmembrada do município de Vera.

A figura 5.7 mostra a rua principal do município.

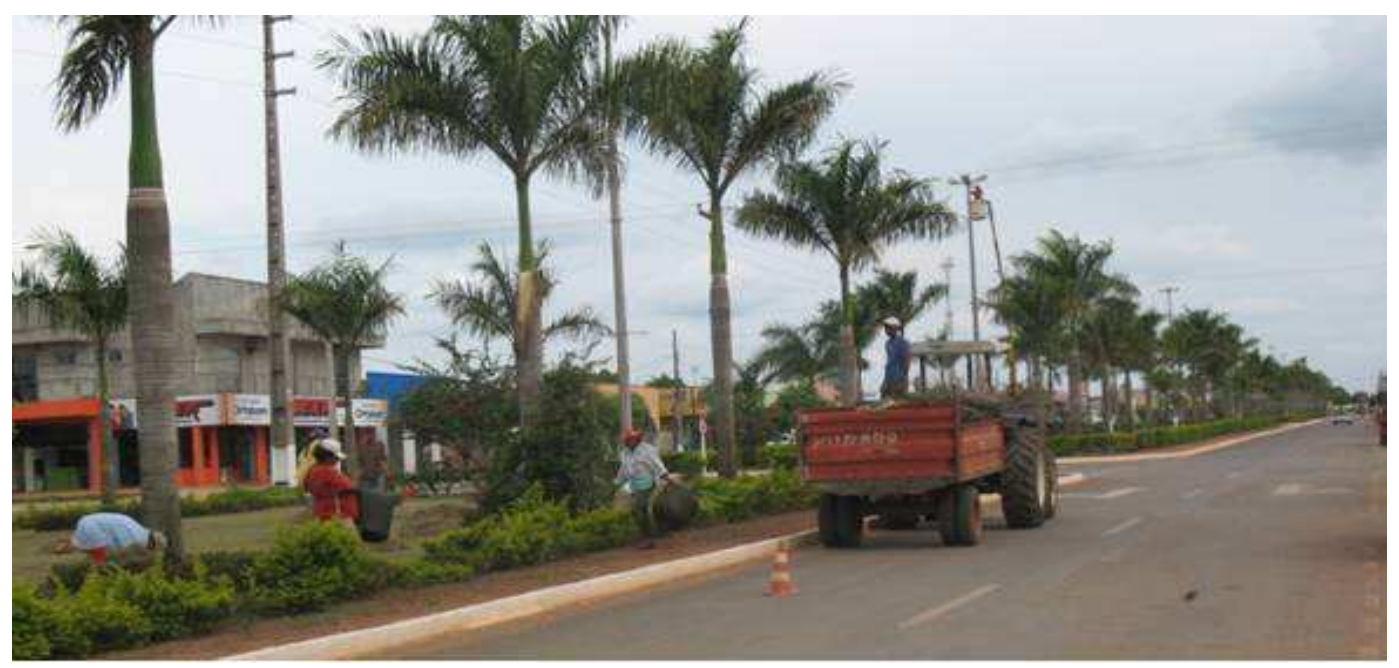

Fonte: Pesquisa de campo, 22/09/2009

Figura 22: Rua principal do Município de Feliz Natal

Dentre as principais atividades econômicas do município, apresentam expressividade a indústria madeireira e agropecuária. Este último esta em fase de crescimento, representando mais de 50\% (cinqüenta por cento) da economia do município. Os principais cultivos são de arroz e soja (com maior área plantada, 3.090 ha). Ainda há rebanho expressivo de 12.000 cabeças de bovinos, de acordo com dados obtidos na prefeitura do município.

A usina Cooperfeliz criou-se em 2007 a partir de uma associação de 21 agricultores. Esses fornecem a matéria-prima e recebem de volta o biodiesel, que será utilizado pelo próprio cooperado na proporção B-100 em suas máquinas agrícolas. Como matérias-primas para produção de biodiesel, a cooperativa utiliza banha de porco e óleo de caroço de algodão que tem origem na região do Norte do Mato Grosso, nos municípios de Terra Nova, Colíder, Sinop, Sorriso.

As figuras 5.8 e 5.9 mostram um panorama da usina Cooperfeliz e maquinário da usina. 


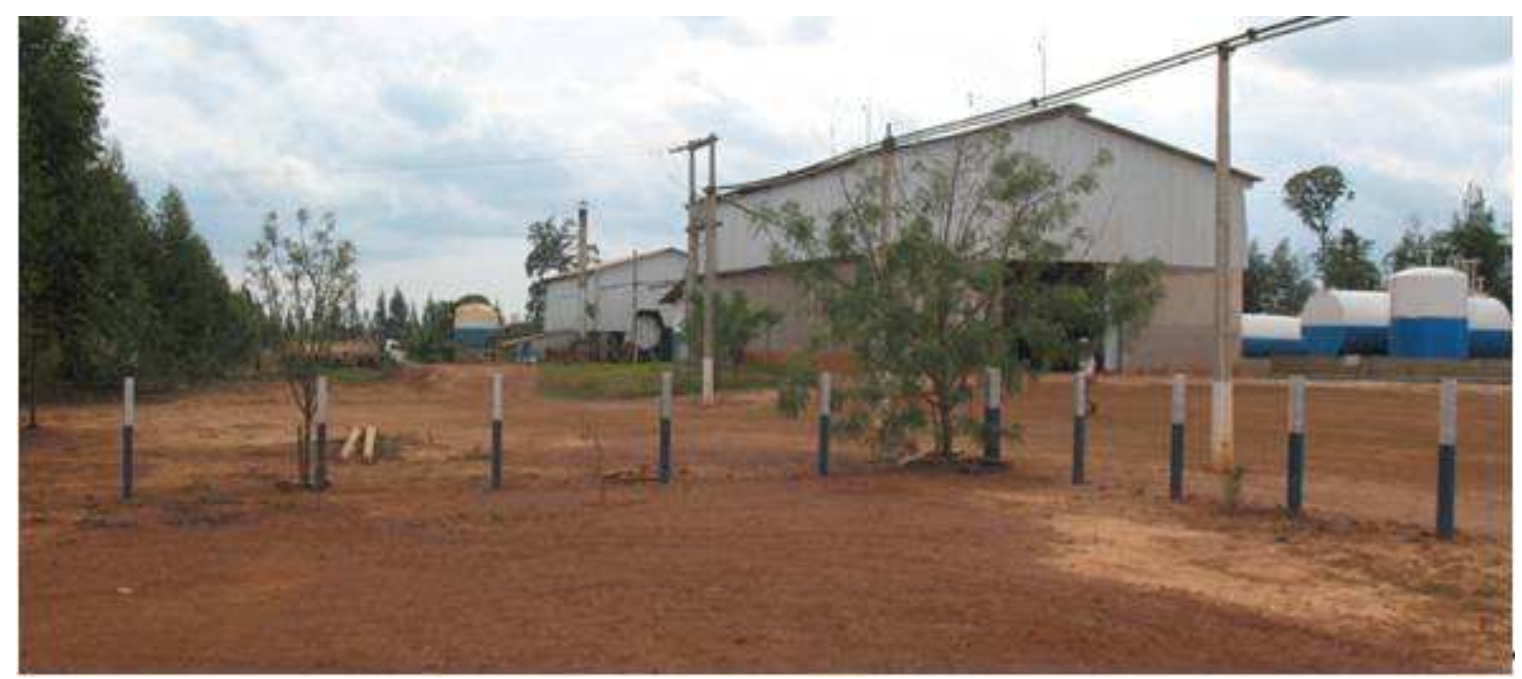

Fonte: Pesquisa de campo, 22/09/2009.

Figura 5.8: Perfil panorâmico da Usina Cooperfeliz - Feliz Natal - MT.

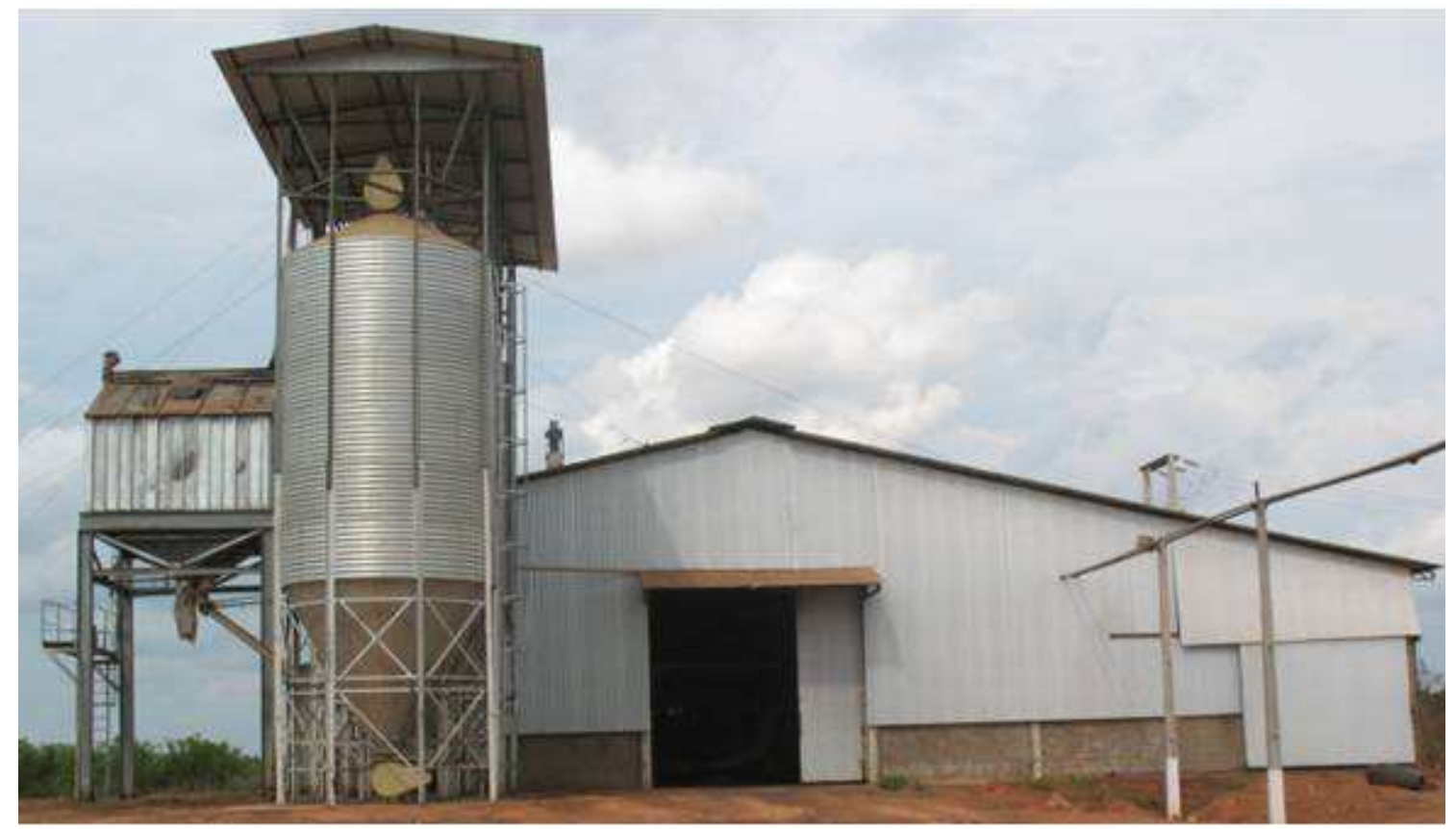

Fonte: Pesquisa de campo, 22/09/2009.

Figura 5.9: Descaroçador de sementes e armazém da

\section{Usina Cooperfeliz - Feliz Natal -MT.}

A produtividade da usina está em cerca de 10 mil litros por dia, autorizados pela ANP. O processo para autorização da ANP ocorreu de "forma tranqüila, simples, em 60 dias, devido 
ao volume produzido que é baixo", de acordo com informações obtidas com representante da usina, Sr. Leandro Martins. Também, não há venda para o mercado por se tratar de uma cooperativa, amparada na Lei do Ato Cooperativo, não recebendo nenhum subsídio ou isenção fiscal dos programas do governo.

Como não tem fins lucrativos, não há venda direta do biodiesel, somente a troca de produtos, dando um custo de cerca de $5 \%$ a mais do preço do diesel mineral, ou seja, $\mathrm{R} \$ 2,05$. A rota tecnológica utilizada é a metílica, e a compra do metanol importado vem do Rio de Janeiro. Equivale a $20 \%$ do valor do diesel.

A preocupação ambiental da usina foi consolidada com o processo de licenciamento e autorização outorgado pela ANP que prevê atendimento à legislação ambiental quanto à origem, produção e utilização de matérias-primas. Assim como para atender às exigências e padrões de qualidade do biodiesel produzido, ensaios foram realizados a fim de contemplar processo adequadamente.

A produção dos 10 mil litros de biodiesel gera um excedente de $12 \%$ de glicerina. Como o volume é baixo, a venda é direcionada a Votorantim, que queima a matéria-prima para produzir cimento, e para assentamento rurais, que produzem sabonetes.

Apesar das dificuldades de grandes usinas em utilizar a banha de porco como matériaprima, a Cooperfeliz, que gera menor volume, podendo acompanhar a produção in loco, com controle mais acirrado de cada processo de produção, viabilizando o seu uso. Numa usina maior, com produção de 80 mil a 200 mil litros por dia, a produção tem que ser padronizada, não permitindo variações ao longo do processo.

Para a produção de 10 mil litros por dia, são realizadas 5 bateladas de 2 mil litros, e todas com acompanhamento do profissional responsável, capaz de averiguar a qualidade do produto, nível de acidez, quantidade de metanol a ser adicionado, de hidróxido, averiguando todo o processo distintivamente. 


\subsubsection{Ponto 3 - Município de Sinop (MT) - Usinas desativadas (KGB)}

O processo de ocupação da área onde hoje está localizado a cidade de Sinop teve início no ano de 1972, quando a Colonizadora Sinop S.A. adquiriu de terceiros, aproximadamente 500 mil hectares de terra situados a 500 km de Cuiabá na BR 163 (Cuiabá-Santarém) e criou a Gleba Celeste.

$\mathrm{Na}$ implantação e execução do projeto, 400 homens e máquinas atravessaram, inicialmente, o rio Verde, abrindo as primeiras picadas na selva para plantar quatro cidades (Sinop, Vera, Santa Carmem e Cláudia), 1.400 quilômetros de estradas vicinais, campos experimentais, centro comunitários, escolas infra-estrutura de apoio para atender aos novos habitantes.

Brasileiros de todas as regiões do país que, num fenômeno de explosão populacional, correram para enfrentar os desafios de ocupação da Amazônia mato-grossense. A abertura das primeiras ruas de Sinop teve início em maio de 1972 e logo as primeiras famílias de pioneiros chegaram à cidade. Naquela época, uma viagem do interior do Paraná até Sinop demorava cerca de sete dias. Mas, apesar dessa grande dificuldade, o fluxo migratório na direção oeste, que acompanhava a expansão da fronteira agrícola no Norte de Mato Grosso, foi crescendo.

O resultado não poderia ter sido outro: no dia de sua fundação, em 14 de setembro de 1974, a cidade de Sinop era um verdadeiro canteiro de obras, com mais de 20 quadras. Tudo foi muito rápido, em menos de dois anos, no dia 24 de julho de 1976, o então governador José Garcia Neto assinou a Lei 3.754/76 elevando Sinop à categoria de distrito do município de Chapada dos Guimarães. Menos de quatro anos depois, no dia 17 de dezembro de 1979, o governador Frederico Campos assinou a Lei 4.156/79, que elevou Sinop à categoria de município.

Hoje, Sinop não pára de crescer. No ano de 1974, ninguém seria capaz de imaginar que após três décadas de emancipação, Sinop contaria com uma população estimada em mais de 100 mil habitantes nesta região norte do Mato Grosso. A cidade é atualmente pólo de referência em todo nortão matogrossense, no que diz respeito à saúde, a educação, indústria, comércio, lazer e entre outras tantas áreas municipais.

Os primeiros agricultores que vieram para Sinop, em 1972/73 dedicaram-se inicialmente ao plantio de café e arroz (riquezas agrícolas representadas na bandeira de Sinop). Enfrentaram um elevado número de dificuldades em razão do elevado teor de acidez 
do solo, terras mais fracas, clima diferente, falta de recursos e outras adversidades. Porém aos poucos foram se adaptando a realidade da região e dedicando-se a outras atividades agrícolas como o cultivo da pimenta do reino, guaraná, milho etc.

A partir de 1975 a agricultura passou a ter um impulso maior principalmente no plantio de arroz, graças à correção do solo com calcário (programa lançado pelo Ministro da Agricultura em Sinop).

Em 1979 foi lançado o programa do plantio da mandioca, este programa era destinado a fornecer matéria prima (mandioca) para a Agro-Química Industrial que estava sendo instalada em Sinop pela colonizadora, para fabricar álcool combustível. Porém vários fatores negativos acabaram frustrando mais uma vez os agricultores locais.

Em razão das tecnologias voltadas à produção agrícola, nos últimos anos, Sinop tem apresentado uma produção agrícola desenvolvida principalmente nas áreas de: soja, algodão, arroz, milho.

Quanto à pecuária, teve um relativo desenvolvimento no município em razão da abertura de várias fazendas de grande porte destinadas à criação de gado, além dos incentivos fiscais concedidos pelo governo Federal através da SUDAM.

Em contato com as usinas produtoras de biodiesel do município autorizadas pela ANP, como a KGB e a Usibio, a inviabilidade de produção paralisou suas atividades, diante os altos preços do óleo de soja. No caso da usina Beira Rio biodiesel, em Terra Nova do Norte, essa desistiu de iniciar a produção devido a dificuldade de legalização da usina e a burocratização solicitada pela ANP, além dos preços não competitivos para a produção de biodiesel.

Outras usinas de pequeno porte também desistiram do processo de licenciamento devido aos custos e a burocratização, já que a solicitação da capacidade a ser autorizada era baixa. Para as usinas que adquirem o selo social são dadas isenções fiscais, mas as que não o obtém arcam com altos impostos e tarifas.

Entre elas, foi possível identificar os motivos mais específicos aos quais levaram a paralisação da KGB, em entrevista com Sr. Camilo Perazolli, dono da usina. A usina está paralisada a quatro meses e tinha produção de 5 mil 1/dia com utilização de principalmente de soja, seguidos de girassol e sebo como matérias-primas.

O girassol era utilizado quando havia excedente, já que nem todo óleo produzido era vendido à indústria alimentícia. Para viabilidade do uso de sebo bovino era feita uma mistura 
com as outras matérias-primas e também considerava-se o preço de venda pago pelo sebo no frigorífico.

As vendas do biodiesel eram destinadas à Petrobrás e a uma transportadora da região, em Rondonópolis que, atualmente, tem sua própria produção de biodiesel. A última venda foi de $\mathrm{R} \$ 2,35$ /l. Porém, como a usina beneficia a soja e o girassol extraindo o óleo, tornou-se mais lucrativo a venda direta para o consumo humano no mercado interno que saiu a $R \$$ $2,00 / 1$.

No caso do óleo de girassol, há demanda em um mercado para um óleo considerado “óleo fino” rico em ômega 9, que, futuramente poderá atender o mercado externo.

Sua transformação em biodiesel envolveria os custos com a importação do metanol e com outros processos. Esses custos acresceriam em torno de $\mathrm{R} \$ 0,55$ ao preço do óleo, dando maior gasto ao processamento.

A glicerina excedente era filtrada e pulverizada nas culturas das fazendas próprias, utilizada como fertilizante. Pouca matéria-prima era comprada de outros fornecedores, sendo esses não participantes de agricultura familiar. A KGB não conseguiu adquirir o Selo Social junto à ANP.

O processo para licenciamento e autorização de produção da usina foi demorado (um ano) e burocrático. A usina atua desde 2007 com a licença, porém já produzia sem autorização. Com a fiscalização, a autorização foi solicitada e atualmente, para produção de biodiesel, a usina está legalizada.

No início, não havia grande competitividade e poucas usinas produziam biodiesel, tendo margem de lucro frente ao custo de produção. Atualmente, sem as isenções fiscais concedidas pelo selo social, há inviabilidade de produção devido aos altos gastos.

$\mathrm{Na}$ opinião do dono da usina, para a viabilidade de sua usina voltar a produzir biodiesel é necessário que preço do óleo abaixe ou os preços de venda do biodiesel aumentem ou que os subsídios do governo atinjam as usinas sem o selo social. 


\subsubsection{Ponto 4 - Município de Colíder (MT) - usina CLV}

A ocupação das terras da região ocorreu no tempo dos incentivos fiscais e projetos do Governo Federal da década de 1970. Quando os soldados do $9^{\circ}$ Batalhão de Engenharia de Construção (BEC) ainda rasgavam a BR 163, Raimundo Costa Filho decidiu colonizar a região, nela entrando no sentido leste-oeste. Raimundo Costa Filho já tinha experiência em colonização no estado do Paraná, e em 1973 chegou a Mato Grosso. Sobrevoou a região e adquiriu extensa área de terras, mudou-se então para o lugar da futura cidade de Colíder, que inicialmente foi denominada de Cafezal.

A criação oficial do patrimônio de Cafezal se deu a 07 de Maio de 1973, considerando o dia do aniversário de Colíder, com o erguimento de um ranchão, que passou a servir de dormitório, armazém, enfermaria e pensão. Era tal a procura de terras que, em 1974, quase toda a Gleba Cafezal já havia sido ocupada. Programou-se, então, a cidade.

A povoação cresceu, passando à denominação de Colíder, utilizou-se das iniciais da palavra Colonizadora Líder (Co + líder), cujo significado descrevia que ali nascia uma unidade social de grande importância ao lado de outra, pois na época, Ênio Pipino já desenvolvia uma colonização de vulto naquela região, estabelecendo Sinop como sede dos empreendimentos. Colíder vinha a ser, então, outra Sinop. Os colonizadores tencionavam criar uma estrutura tal que justificasse o seu nome de liderança.

Em 18 de Dezembro de 1979, através da Lei Estadual nº.4.158, foi criado o município de Colíder, que se tornou famoso devido à produção agropecuária e também aos garimpos nas décadas de 80 a 90; passando pelo processo de extração de madeiras e, por conseguinte a pecuária e a industrialização através de frigoríficos, laticínios e curtume, atividades do comércio e prestação de serviços.

Atualmente, tem destaque a criação bovina com 400 mil cabeças, além de pequenos projetos de agricultura familiar com produtividade significativa de produtos hortifrutigranjeiros, valorizando a produção de produtos orgânicos e fruticultura.

A usina CLV Agrodiesel pertence ao grupo Guaporé carnes. Sua certificação ocorreu em 2007, mas devido aos custos altos das matérias-primas, manteve-se paralisada iniciando suas atividades em 2008. Apesar da atividade principal da empresa ser frigorífico, o sebo bovino não é a matéria-prima base para produção de biodiesel, ele é utilizado somente 
misturado. As matérias-primas são óleo de soja, girassol e algodão, sendo a soja a base principal, com participação de $70 \%$.

A figura 5.10 mostra os tanques de armazenamento da usina CLV.

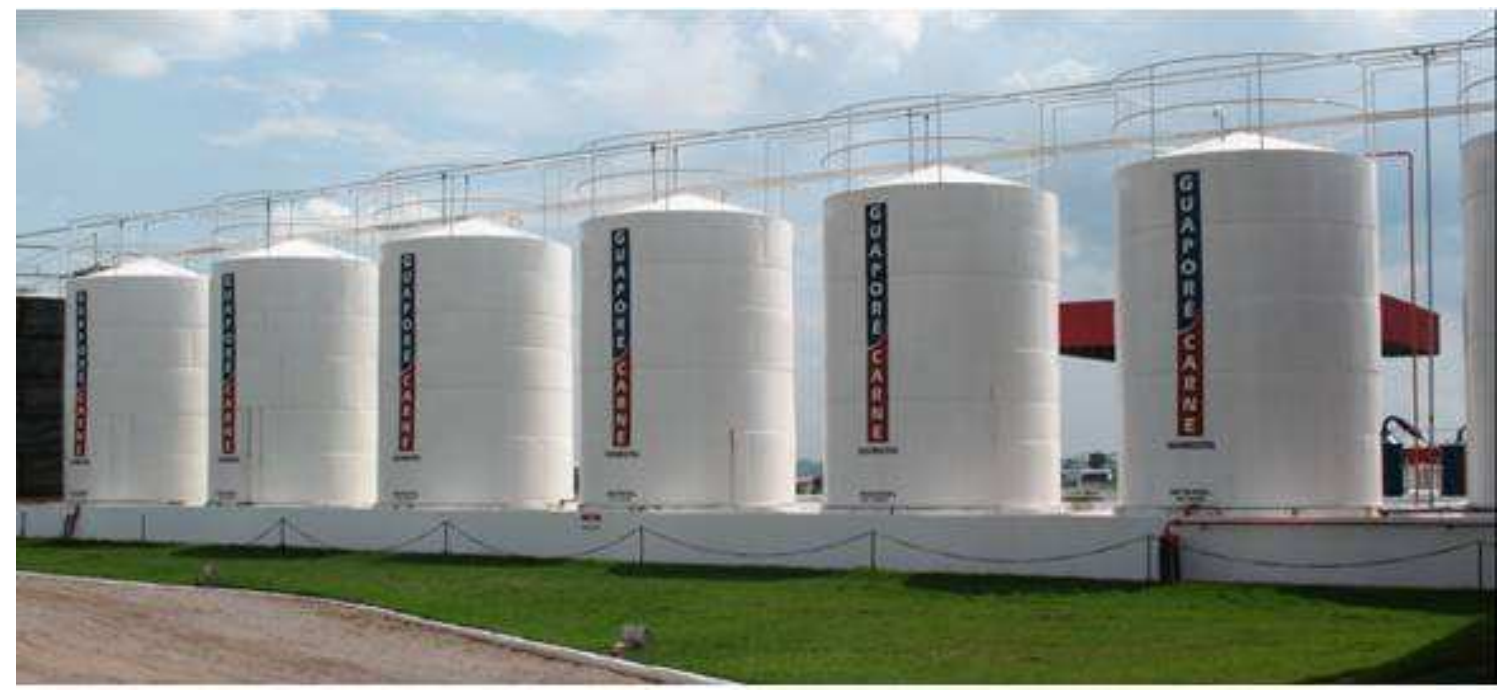

Fonte: Pesquisa de campo, 23/09/2009.

Figura 5.10: Tanques de armazenamento da Usina CLV - Colíder - MT.

A produtividade da usina é de 150 mil litros por dia, sendo 100 mil 1/dia autorizados pela ANP. Atualmente, solicitou-se a autorização para produção de $200 \mathrm{mil}$ 1/dia. A venda é destinada diretamente à Petrobrás, que arca com frete e retirada do produto. Os leilões são realizados trimestralmente e no último leilão, ocorrido em agosto de 2009, a CLV teve sua venda a $\mathrm{R}$ \$2,28/1. A empresa vendeu 6 milhões de litros.

O óleo de soja é adquirido de empresas esmagadoras da região, como a Agrossoja e a Bunge. Para minimizar os gastos com transporte e logística, a empresa prioriza esmagadoras que estão localizadas entre Cuiabá e Colíder. Há projetos para o processamento do óleo na empresa, mas que deverão ser colocados em prática somente a partir de 2010, como informado pelo diretor geral Sr. Usias Isidoro.

Os custos referem-se à compra do óleo de soja, que foi adquirido por $\mathrm{R} \$ 1,50$ na última vez e mais os custos operacionais, que estão em torno de $\mathrm{R} \$ 0,40$ a 0,50. Apesar dos preços do óleo serem dados pelas commodities internacionais, sendo desvalorizado, regionalmente, ele é comercializado a preços maiores. 
A rota utilizada é a metílica e o metanol importado chega por meio dos portos de Santos - SP e Paranaguá - PR. A proporção de metanol adicionado no processo é de 16 a 20\% da quantidade de óleo. A empresa não recebe subsídios para produção, mas tem alguns descontos em impostos como ICMS e Cofins.

O licenciamento solicitado pela ANP foi, inicialmente, menos rigoroso do que a solicitação para ampliação de produção da usina, que é mais burocrático e exigente. Pela avaliação do diretor, o processo de licenciamento é burocrático, embora seja necessário para que as usinas possam produzir com qualidade, atendendo as especificações exigidas.

A glicerina excedente é vendida à indústria de cimento Votorantim, que a queimam para os processos que exigem altas temperaturas. Para a substituição da lenha queimada na caldeira da usina, algumas pesquisas foram realizadas acerca da queima da glicerina. Porém, foram detectados entraves tecnológicos os quais exigem grandes investimentos e compra de peças importadas, o que inviabiliza esse aproveitamento na escala atual.

A figura 5.11 mostra um dos tanques de armazenamento de glicerina.

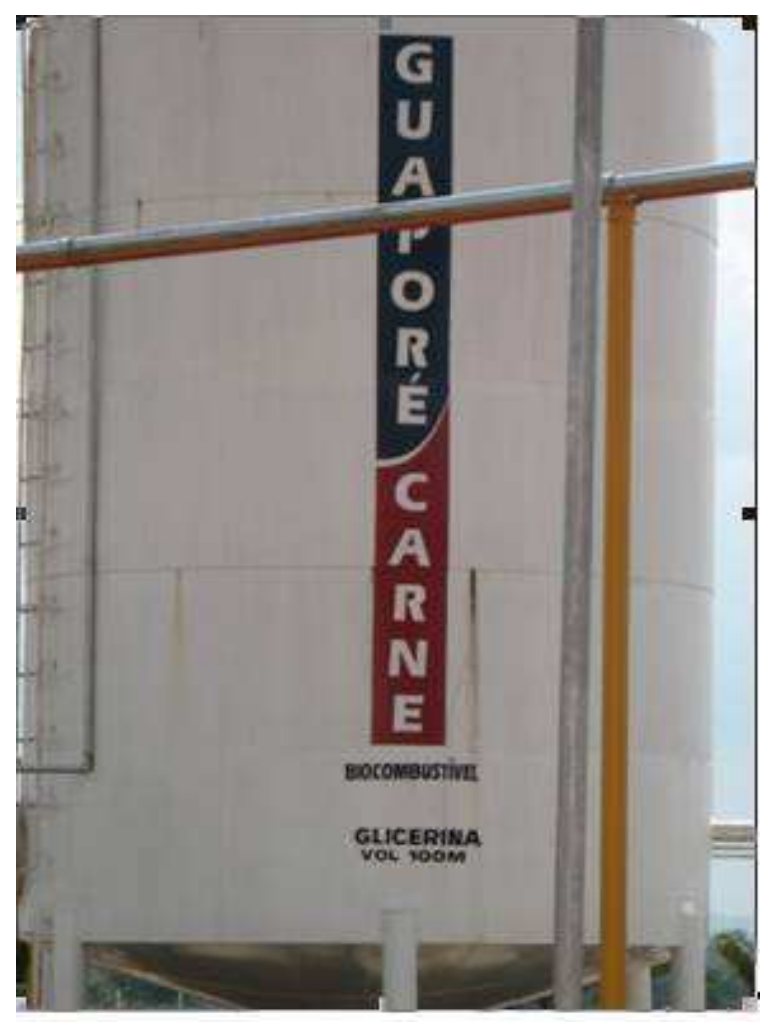

Fonte: Pesquisa de campo, 23/09/2009.

Figura 5.11: Tanque de glicerina da usina CLV - Colíder - MT. 
No futuro, com abertura do mercado as vendas da usina deverão abranger sua região, ou seja, atendimento a um mercado regional no Mato Grosso, para que os custos com frete e logística não inviabilizem a produção. Mesmo com caminhões próprios, o combustível utilizado é o diesel vendido nos postos, pois o biodiesel apresenta maiores custos.

A preocupação ambiental é dada pelo cumprimento da legislação e exigências da ANP e SEMA. Como a usina compra o óleo diretamente da beneficiadora, não é possível saber a origem da soja (agricultura familiar ou não). Há projetos recentes na cidade de Colíder com agricultura familiar de amendoim, porém o biodiesel de amendoim é mais custoso. Ainda sim, a usina compra óleo ou grãos de cooperativas, localizadas em Terra Nova do Norte, Feliz Natal (Cooperfeliz).

Quando há compra de grãos, troca-os por óleo em empresas esmagadoras, estimulando a produção de pequenos agricultores. Também, a usina oferece assistência técnica de profissionais especializados, como agrônomos e técnicos agrícolas às cooperativas.

Ainda, há um projeto da usina em parceria com a SEMA de ferti-irrigação do pinhão manso. Há uma pequena plantação na área da usina que utiliza a água residual do processo na irrigação. Não cogita-se sua utilização como matéria-prima para produção de biodiesel pois ainda é uma cultura muito nova, necessitando de pesquisas mais aprofundadas para viabilidade e segurança de produção.

A figura 5.12 mostra a plantação de pinhão manso.

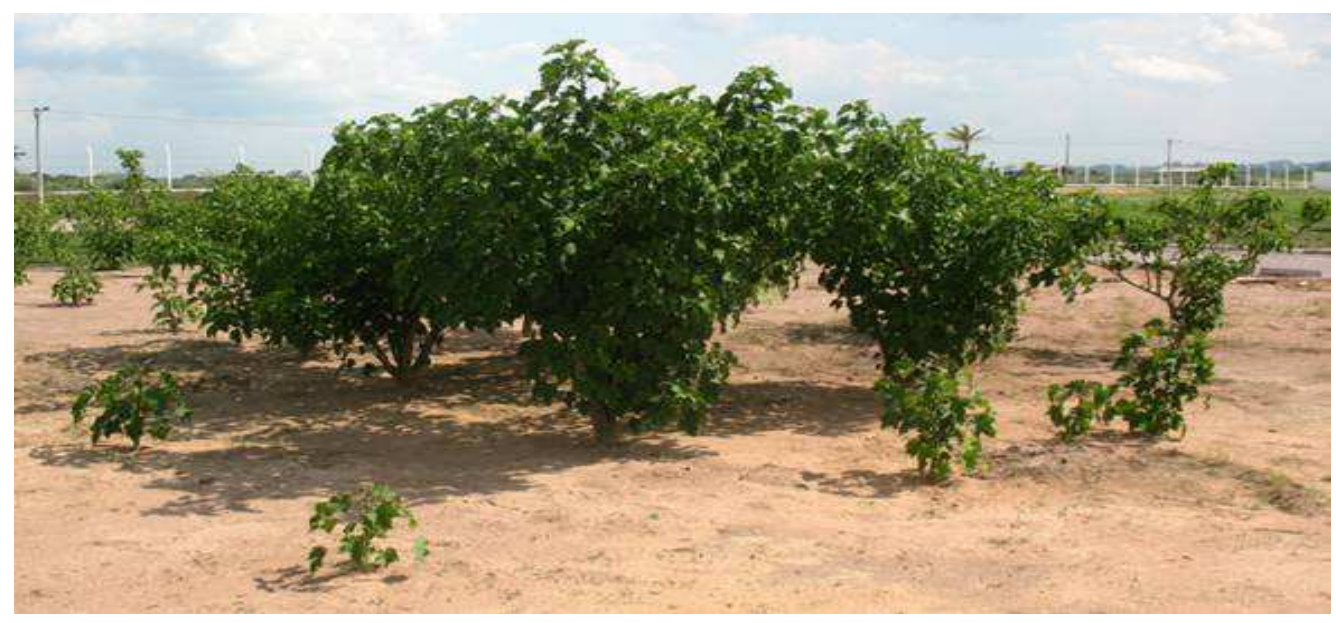

Fonte: Pesquisa de campo, 23/09/2009.

Figura 5.12: Projeto de plantação de pinhão-manso promovido pela usina CLV e SEMA para ferti-irrigação. 


\subsubsection{Ponto 5 - Município de São José do Xingu}

Como mencionado anteriormente, o histórico do município de São José do Xingu e suas características gerais foram descritos no capítulo 5.3. Verifica-se que a região está consolidada como área produtora de gado bovino, entretanto, desde 2002, a soja vem se expandindo nas fazendas.

Foram visitadas a prefeitura, o Empaer, o Indea e as fazendas Santa Maria, Bang-bang e Limoeiro (as maiores que apresentam plantio de soja) e realizadas entrevistas com os responsáveis locais para averiguar como a soja tem se expandido na região e quais seus destinos. Também, foram abordadas questões sobre meio ambiente e sua recuperação.

$\mathrm{Na}$ prefeitura foram entrevistados Sr. Alcides Martins, secretário da agricultura do município e o Sr. Gilberto Mendes Leoncini, prefeito do município. Foram obtidas informações referentes à história da cidade e a economia local.

A figura 5.13 mostra a fachada da Prefeitura Municipal.

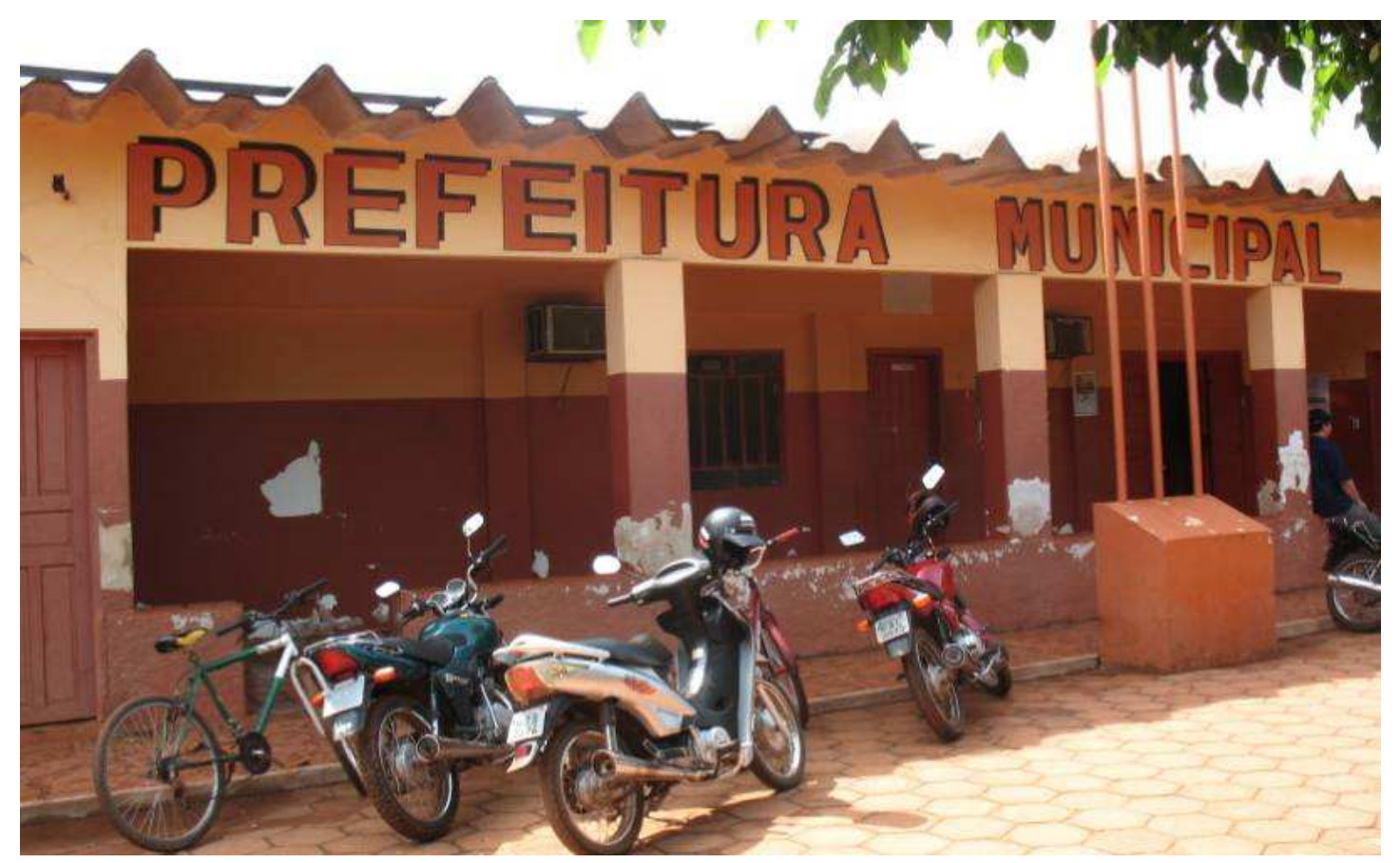

Fonte: Pesquisa de campo, 24/09/2009.

Figura 5.13: Fachada da Prefeitura Municipal de São José do Xingu

A pecuária ainda é o carro-chefe de geração de renda na região. A produção de soja, que iniciou-se na região a partir de 2002, encontra-se em algumas fazendas como a Reunidas, 
Bang-bang, Santa Maria, Limoeiro, Felicidade, Califórnia, Flor da Mata, Barra do Dia. Importante lembrar que a maior parte dos proprietários das fazendas da região mora no estado de São Paulo e Rio de Janeiro, estando no local somente uma vez ao ano.

Contudo, como não há beneficiadoras de grãos na região, a soja apresenta baixo valor agregado Seu principal destino são as secadoras mais próximas, como a Cargill, que localizase a $35 \mathrm{~km}$ do município, e a Bunge, a $70 \mathrm{~km}$. A usina de biodiesel mais próxima está localizada em Porto Alegre do Norte, cerca de 200 km de distância de São José do Xingu, o que inviabiliza a produção de soja de São José do Xingu para tal fim.

A maior preocupação da produção da soja é a questão da logística e transporte. A maior parte das estradas que ligam o município a outras regiões são de terra, de difícil acesso e, ainda, propensas a alagamentos em época chuvosa (de setembro a maio), que acarretam até o isolamento da cidade.

Os custos com frete representam ônus aos produtores que muitas vezes optam pela criação de gado que têm preços que não oscilam tanto no mercado e se apresenta como investimento de menor risco. A soja depende dos preços internacionais, dos insumos e das condições climáticas, o que pode acarretar maiores custos ou, até mesmo, perda da produção.

O Senhor Prefeito Gilberto Leoncini relatou que, além dos entraves com transporte, há gastos com adubos e corretivos de solo, como o calcário, além de alta nos preços do grão, como ocorreu em 2004. Esses fatores desmotivaram a produção em 2005/06, apesar do potencial iminente do município devido às condições geográficas favoráveis.

No Empaer foi entrevistado o Sr. Emanuel Martins, técnico agrícola. O Empaer promove assistência aos assentamentos e à agricultura familiar da região. Sr. Emanuel relatou sobre o início dos assentamentos na cidade. Os terrenos foram invadidos em 1973, ocorrendo o loteamento e assentamento em 1978, dando origem ao projeto Aimoré e Yamin, assim como Santo Antonio do Fontoura (descritos no capítulo 5.3)

Atualmente, apenas $10 \%$ dos assentamentos correspondem à produção agrícola familiar já que a maior parte dos lotes foram vendidos e seus proprietários migraram à cidade. As vendas fazem com que os lotes se emendem e virem fazendas de criação de gado. Em Santo Antonio do Fontoura há maior produção, principalmente de milho e arroz porque os loteamentos são maiores que dos outros assentamentos. 
Interessante relembrar que, no início da ocupação da região, na década de 70, havia incentivos para o desmatamento da floresta, por meio de leis, recursos financeiros que estimulavam a criação de pastos. Era nessa época que os conflitos entre peões de fazendas aconteciam levando a muitas mortes e dando origem ao nome do vilarejo de Bang-bang.

Atualmente, as áreas desmatadas devem ser recuperadas sob fiscalização do IBAMA e SEMA. Até maio de 2001, a lei determinava que desmatamentos que representassem até 50\% da área total do terreno poderiam manter-se. Porém a partir de 2001, os estabelecimentos rurais têm obrigação de recuperar $80 \%$ da área desmatada. Como há predomínio de latifúndios, há grande dificuldade em cumprimento da lei, dando prioridade às cabeceiras e leito dos rios, assim como áreas alagáveis, que correspondem às APPs.

Junto com o sindicato rural e o ISA há projetos de recuperação de APPs, conscientização ambiental e regularização de terras como o o Y Ikatu e Proxingu. As APPs devem ser recuperadas e não podem ser compensadas, tentando ao máximo, restabelecer a vegetação nativa do local. Muitas foram desmatadas inteiramente o que gerou erosão do solo e assoreamento dos córregos.

Apesar da conscientização ambiental, percebe-se que a preocupação dos produtores está muito mais ligada à produção e venda do boi ou grãos que efetivamente com o meio ambiente. Isso porque as certificações ambientais devem ditar o mercado de venda e compra de produtos, que só serão aceitos se produzidos adequadamente, em respeito à lei e ao meio ambiente. O mercado está começando a se preocupar não só com o produto final, carne ou grão, mas como ele foi produzido.

No Indea - Instituto de Defesa Agropecuária - foi entrevistado Sr. Elmídio. A função do Indea no município é fiscalizar o trânsito de animais, vegetais e de agrotóxicos da região. Sr. Elmídio relatou que as culturas de grãos estão ocorrendo em áreas de pastagem antiga Há a areação e adubação do pasto desgastado para plantar capim para novo pasto ou lavoura de milho, soja ou arroz. Também relatou sobre os destinos do gado e grãos da região.

O gado destina-se para cidades de maior porte, como Vila Rica, Independência, Matupá e Barra do Garça no estado do Mato Grosso e Araguaína no Tocantins, onde existem os frigoríficos, como JTF e Betim. E a soja, após passar pelas secadoras, dirige-se aos portos de Santarém e Belém no Pará, e Itaqui em São Luis no Maranhão. 
Em visita à fazenda Bang-bang, foi entrevistada Sra. Marta, gerente administrativa da fazenda, que atua desde 1993, junto ao proprietário Sr. Luis Carlos Castelo que adquiriu posse nesse mesmo ano. A fazenda possui 13 mil hectares de área útil, sendo 3 mil reservadas a APP e conservação e 4 mil hectares de área de compensação no município de Colniza (MT).

Sempre foi consagrada pela produção agropecuária, principalmente de gado bovino. Em 2004, associou-se à pecuária a agricultura de soja e arroz com objetivo de reformar os pastos degradados.

As áreas de plantio variam nos anos dependendo dos preços dos produtos no mercado. A soja deixou ser plantada em 2007 e 2009, devido aos custos altos e preços não atraentes. Em 2009, apenas pequenas áreas iriam ser utilizadas para testes e para não manter o solo descampado e propenso à erosão. As culturas de soja da fazenda são em áreas grandes e planas, havendo pouca mão-de-obra envolvida sendo que todo o processo ocorre por meio de máquinas agrícolas.

A figura 5.14mostra solo sendo preparado com uso de arado

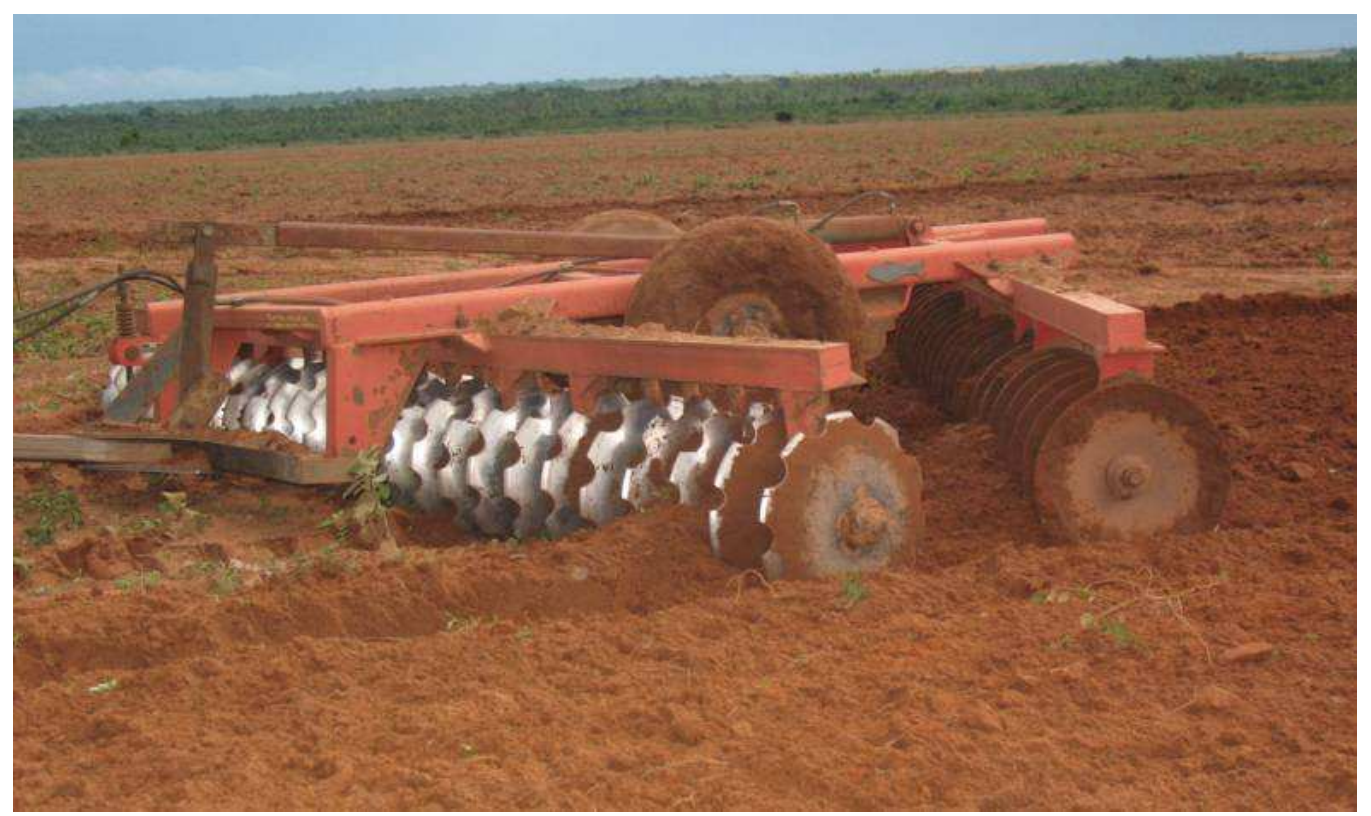

Fonte: Pesquisa de campo, 26/09/2009.

Figura 5.14: Preparo de solo para plantio com uso do arado.

Mais uma vez, citam-se os custos altos envolvidos no transporte do produto, seja para o frete do calcário, defensivos agrícolas e adubo, ou seja, para levar a soja ao seu destino final. 
Apesar da volatilidade de produção, calcula-se uma produtividade média de 48 sacas por hectare, sendo que de $30 \%$ a $40 \%$ dos custos referem-se ao transporte.

A soja era repassada às secadoras mais próximas, Cargill e Bunge, porém, devido ao baixo volume de produção da região, a Cargill foi desativada, restando a Bunge como principal destino dessa soja. Como essas são empresas transnacionais, o preço da soja pago às fazendas é determinado diretamente pelo preço do produto no mercado internacional.

A fazenda Bang-bang, em sua última safra de 2008/09, vendeu a saca do grão de soja a $\mathrm{R}$ \$ 40,00, sendo que as previsões para maio/2010 são de $\mathrm{R} \$ 20,00$ a saca, embora os preços dos insumos não caíram nada, tornando inviável a produção para o ano de 2009.

Em relação à preocupação ambiental, Sra Marta relata que, apesar de ser um conceito novo, já que o governo incentivava o desmatamento na região, atualmente é um item fundamental, e grande parte do desmatamento da região cessou. Para cumprimento da lei, em 2003/04 a fazenda iniciou um processo de recuperação das áreas degradas. Foi feito um levantamento ambiental identificando, com uso do georreferenciamento, as áreas degradadas e cabeceiras de rios,

A partir desse documento, obteve-se o TAC - Termo de Ajustamento de Conduta que indicava a obrigatoriedade da fazenda em adequar 50\% de sua área como uma reserva ambiental e restabelecer as 49 nascentes degradadas no período de 10 anos. Quatro mil hectares foram adquiridos em Colniza (MT) e três mil respondem a reservas na própria fazenda, em geral as APPs.

As figuras 5.15 e 5.16 mostram áreas de APP com mata nativa não degradada e degradada. 


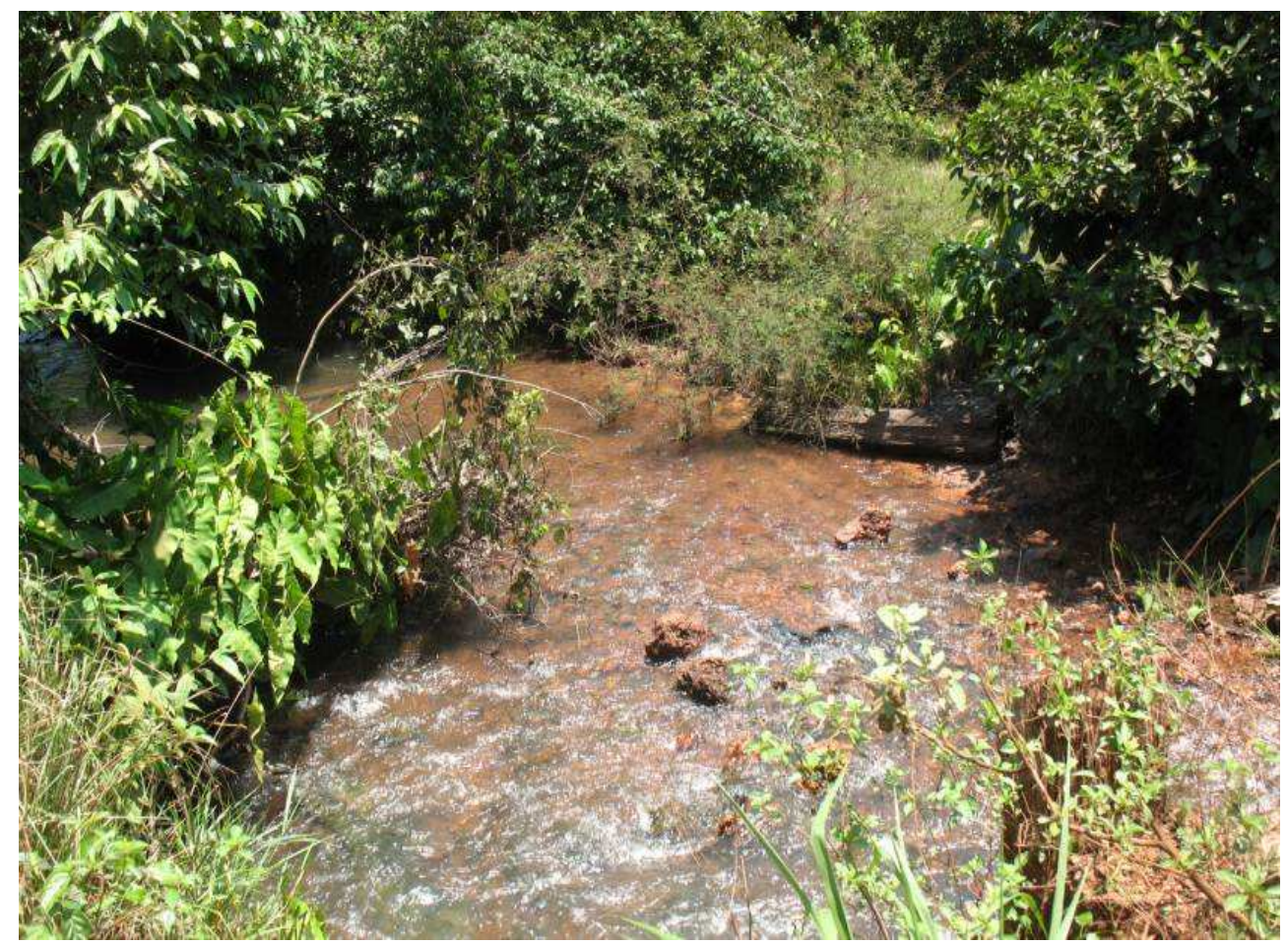

Fonte: Pesquisa de campo, 26/09/2009.

Figura 5.15: APP não degradada com mata nativa na Fazenda Bang-bang

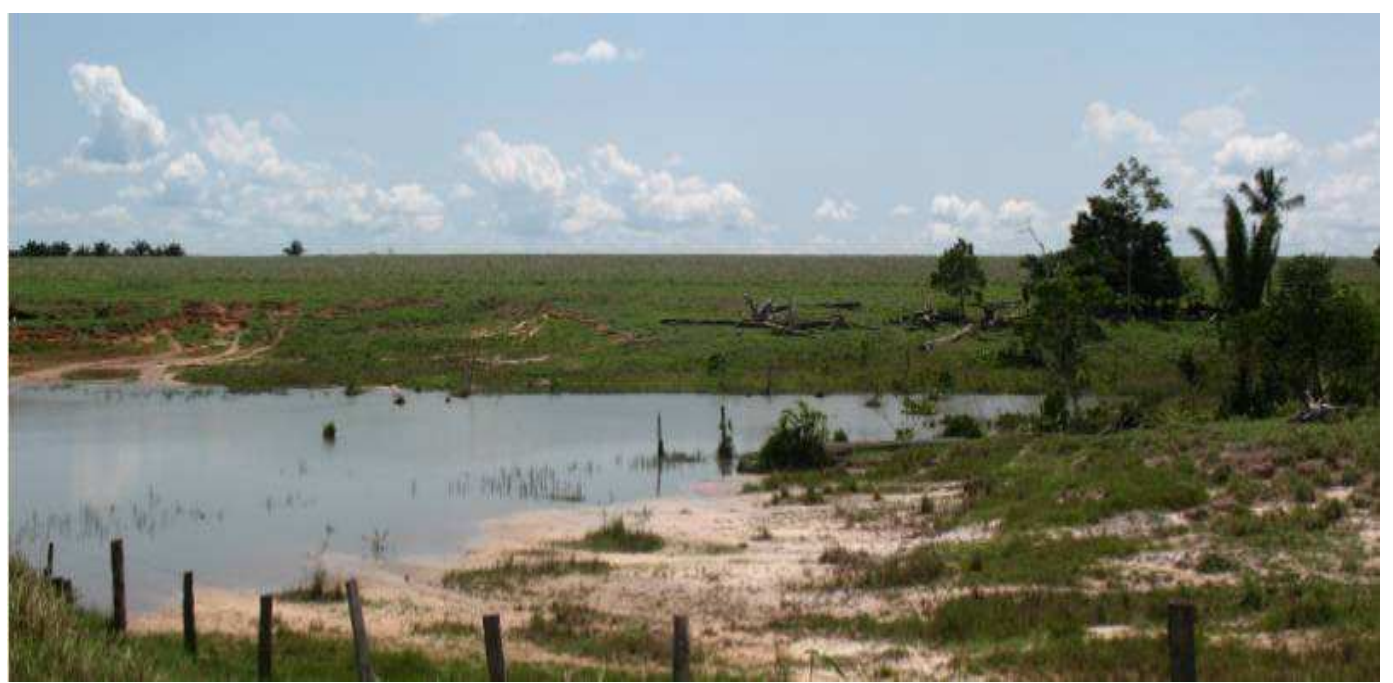

Fonte: Pesquisa de campo, 26/09/2009

Figura 5.16: Degradação de APP na cabeceira do rio na Fazenda Bang-bang 
Com isso, adquiriu-se a LAU - licença ambiental única. Essa licença certifica que toda a produção da fazenda ocorre de modo ambientalmente benéfico e adequado às exigências da lei, respeitando as APPs e áreas de reserva obrigatória.

Para o reflorestamento das nascentes, várias técnicas de replantio foram testadas, havendo necessidade de especialistas para recuperação das APPs, já que elas devem ser recuperadas de acordo com a mata nativa local. Mas só em 2006, em contato com o ISA e o projeto Y Ikatu, de recuperação das cabeceiras do rio Xingu, que a Bang-bang teve êxito nas primeiras áreas recuperadas.

A figura 5.17 mostra a referência da fazenda em associação com o projeto do ISA.

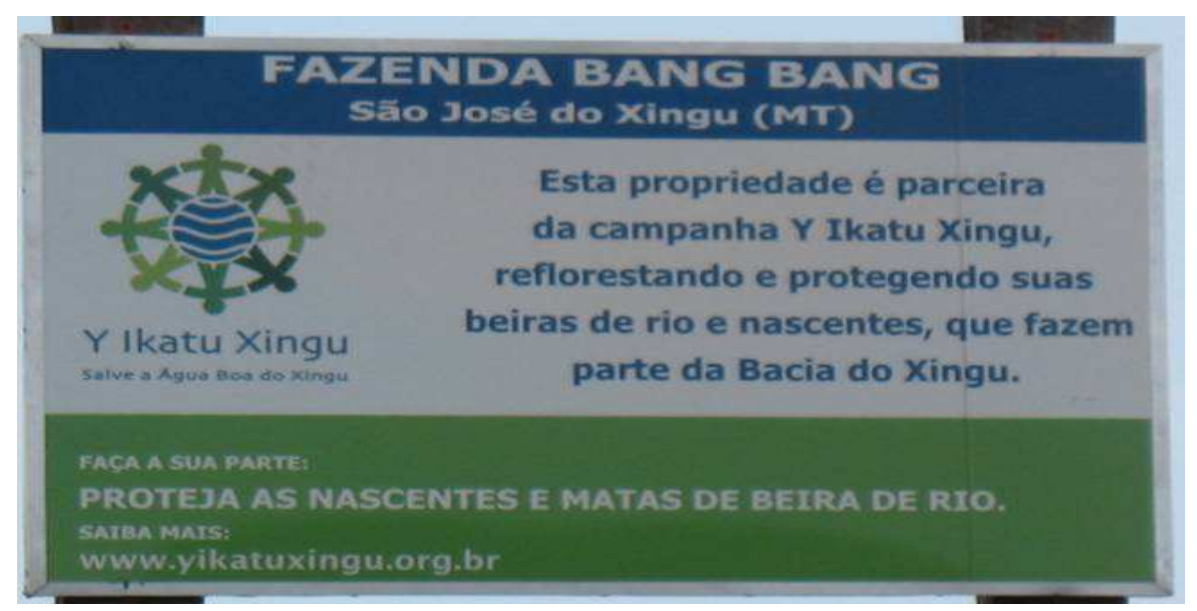

Fonte: Pesquisa de campo, 26/09/2009.

Figura 5.17: Placa da Fazenda Bang-bang em referência ao Projeto Y Ikatu.

O ISA, e também o SENAR (Serviço Nacional de Aprendizagem Rural de Mato Grosso) ensinaram técnicas de manejo florestal e reflorestamento aos funcionários da fazenda por meio de palestras e cursos. Nos fins de semana os funcionários começaram a fazer mudas de espécies nativas que, posteriormente, seriam vendidas e plantadas nas áreas de cabeceiras dos rios. Até então, as técnicas antes empregadas não tinham sido bem sucedidas.

Atualmente, a fazenda enquadra-se num contexto de responsabilidade social e sustentabilidade ao promover melhorias sociais e ambientais em sua área. Houve a contratação de mais funcionários somente em função do replantio dessas mudas que, deviam ser plantadas e monitoradas manualmente para poderem nascer corretamente e não serem sufocadas pelo capim.

Com mais experiência foi possível adquirir as sementes corretas, por meio de coletas na floresta, obter resultados positivos de reflorestamento. Para as coletas em árvores mais 
altas, o rapel foi ensinado aos trabalhadores e atualmente, a semente não representa mais um problema para a fazenda, pois os coletores formaram uma rede de sementes.

O replantio inicia-se com espécimes de leguminosas como feijão andu, feijão de porco que nascem rápido e fazem sombra para que espécies como o jatobá, pequi e a peroba-rosa possam se desenvolver. Essas áreas de recuperação podem representar mercado potencial de crédito de carbono.

Uma área consolidada demora cerca de três anos para se estabelecer e é reconhecida pelo tamanho das árvores plantadas, que ultrapassam dois metros. Essas árvores, ao tempo que crescerem, mata os capins que antes podiam danificar as plantas menores, e o único perigo iminente seria o fogo, diante a possibilidade de uma queimada natural ou predatória.

Hoje, a fazenda tem áreas em todos os níveis de reflorestamento, sendo as primeiras consolidadas a aparecerem de 2009 na figura 5.4, mostra área de recuperação de APP consolidada.

$\mathrm{Na}$ fazenda Limoeiro foi entrevistado Sr. Clésio, gerente da fazenda. Consagrada como fazenda pecuarista, se beneficiou como produtora de soja a partir de 2003. Possui uma área de 2.500 hectares, sendo 1.000 hectares reservados e 1.500 direcionados ao plantio. Assim como a fazenda Bang-bang, há um trabalho de recuperação das APPs degradadas junto ao ISA e o projeto Y Ikatu.

A produtividade média da Limoeiro é de 56 sacas por hectare e a última safra, em janeiro de 2009, a saca foi vendida a $\mathrm{R} \$ 38,00$. A fazenda possui seu próprio secador como mostra a figura 5.18 . 


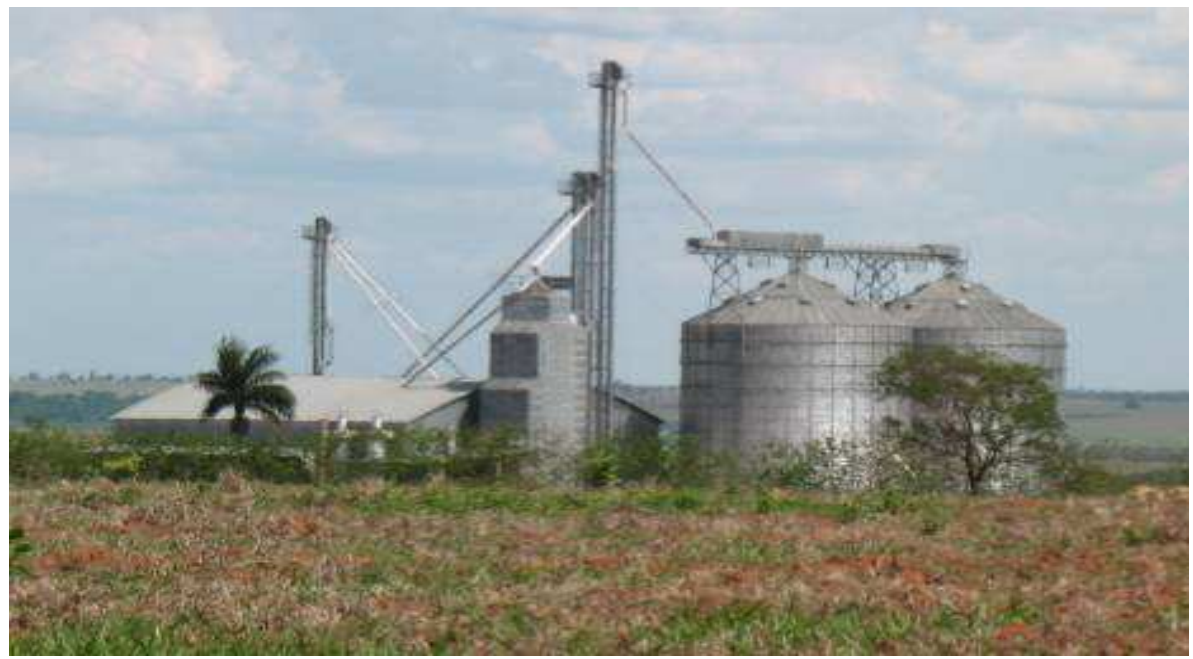

Fonte: Pesquisa de campo, 26/09/2009.

Figura 5.18: Secador de grãos da fazenda Limoeiro.

Após a secagem, a saca é direcionada aos armazéns da região ou destina-se ao Pará para ser exportada. Na produção da Limoeiro, esses gastos respondem a 20\% dos custos. Em geral, o caminhão transporta a soja para os portos e volta com insumos para o solo. Na figura 5.19 é possível observar preparo de solo da fazenda com uso do calcário.

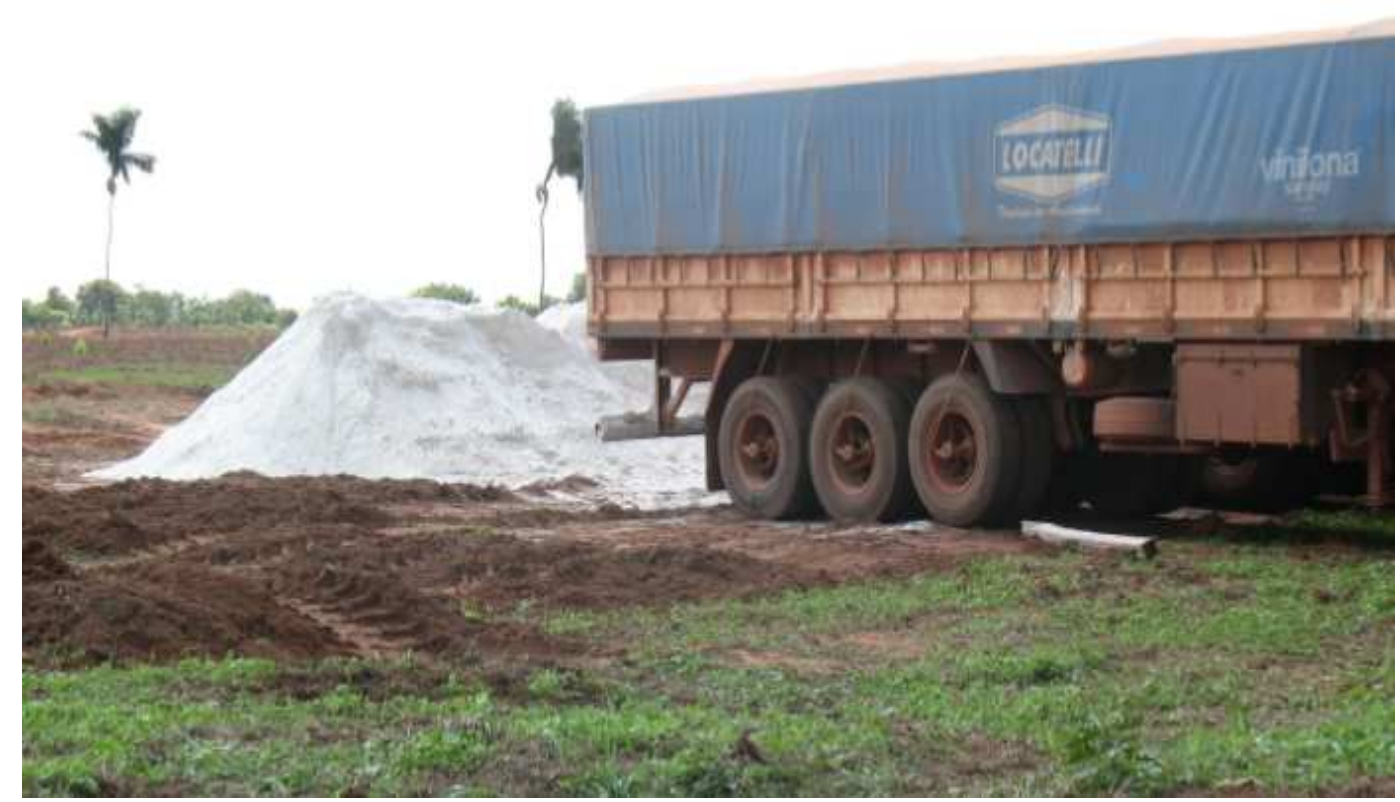

Fonte: Pesquisa de campo, 26/09/2009.

Figura 5.19 Preparo de solo com uso do calcário na Fazenda Limoeiro. 
$\mathrm{Na}$ fazenda Santa Maria foi entrevistado Sr. Aires Centenário, gerente da fazenda, que possui 15 mil hectares. A fazenda, assim como as outras, era caracteristicamente pecuarista e passou, a partir de 2005, a plantar soja. A escolha da matéria-prima foi dada pela experiência do atual proprietário, Sr. Oscar Luiz Sérgio, que possui outras fazendas em Coxim (MS) e Campo Novo (MT) com culturas de soja.

A figura 5.20 área de plantio da mesma Fazenda, com solo terreno plano que favorece a mecanização agrícola

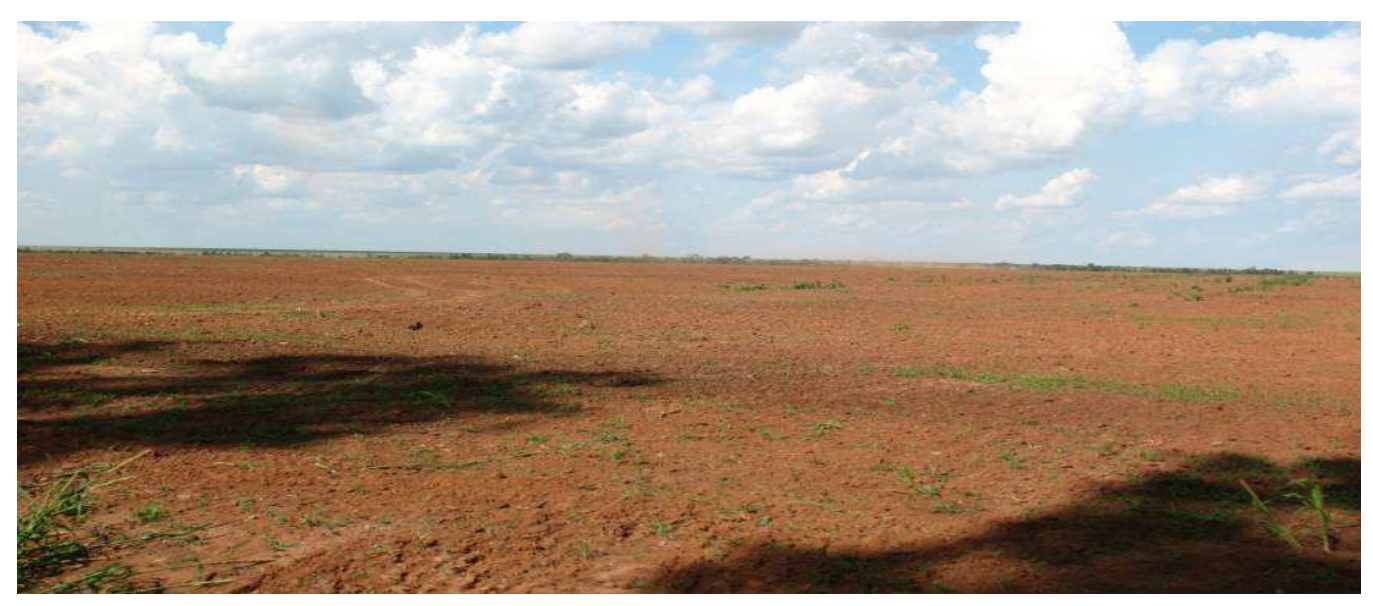

Fonte: Pesquisa de campo, 26/09/2009

Figura 5.20: Área de plantio na Fazenda Santa Maria.

A produtividade está aproximadamente em 54 sacas por hectare e a última safra foi vendida a $\mathrm{R} \$ 32,00$ a saca de $60 \mathrm{~kg}$. Alguns defensivos agrícolas são utilizados no terreno em uma proporção de $700 \mathrm{ml} /$ hectare, com intuito de matar percevejos e lagartas, pragas comumente encontradas na soja. A mão-de-obra é mecanizada e contratada sazonalmente, na época do plantio (outubro) e da colheita (janeiro)

Para garantir nutrientes no solo, há rotação de culturas. O milho é plantado após a colheita da soja, que ocorre no final de janeiro. Após a colheita do milho, que é em julho, ocorre o plantio do milhete ou sorgo. Estes dois têm por objetivo apenas manter o solo coberto, pois sua palha recupera os nutrientes e evita a erosão, funcionando como adubo natural. E, no fim do mês de outubro inicia-se o plantio da soja.

A figura 5.21 mostra o "correntão" sendo puxado por trator na fazenda Santa Maria para assentar a palha do milhete. 


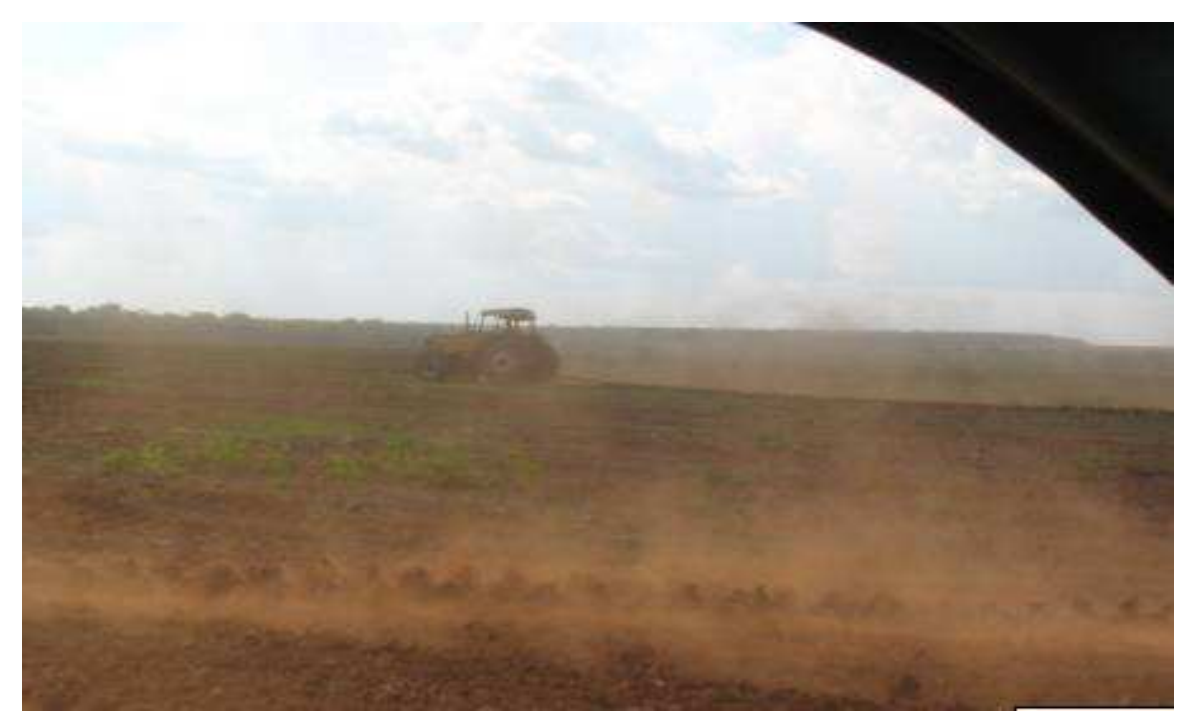

Fonte: Pesquisa de campo, 26/09/2009.

Figura 5.21: Preparo de solo com uso do “correntão"na Fazenda Santa Maria

A figura 5.22 mostra área de plantio com milhete e sua palha. Interessante notar a Floresta ao fundo dessa imagem

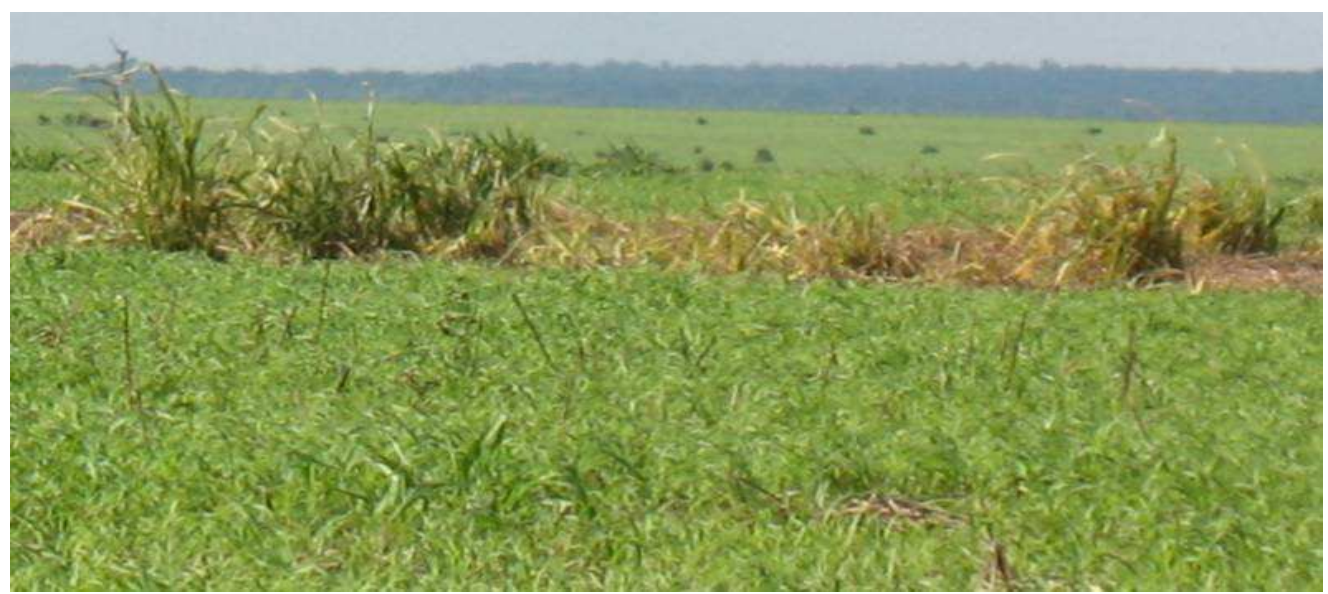

Fonte: Pesquisa de campo, 26/09/2009

Figura 5.22: Preparo de solo com a palha do milhete na Fazenda Santa Maria

Há grande preocupação em manter as áreas de cabeceira dos rios intactas. Preserva-se com mata nativa e não há o desmatamento dessas áreas. Também, como a área da fazenda limita-se com a Reserva Indígena do Xingu, há preservação de $1 \mathrm{~km}$ de mata antes mesmo da 
fronteira. A figura 5.23 mostra a área de contato entre o terreno para plantio e a Floresta Amazônica na Fazenda Santa Maria..

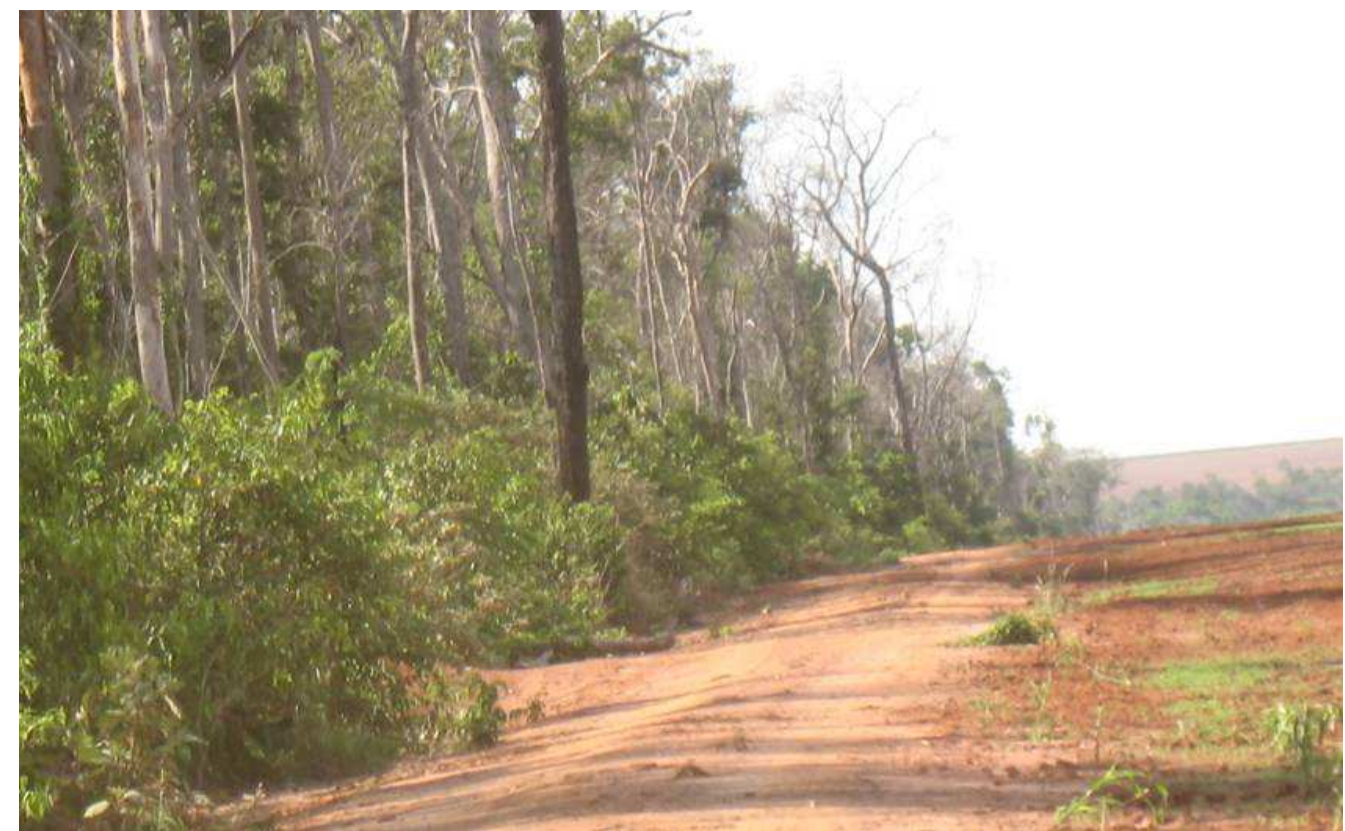

Fonte: Pesquisa de campo, 26/09/2009

Figura 5.23 Área de plantio na Fazenda Santa Maria limitando-se com a Reserva. 


\subsection{Análise dos mapas de uso de solo na região de estudo}

Como detalhado no capítulo 1.2. Metodologia, a ferramenta utilizada nesse estudo foi o geoprocessamento e o sensoriamento remoto. A partir das imagens do satélite LANDSAT 5, à órbita 225 e ponto 67 de 1984, 1994 e 2009 da área de estudo, obteve-se uma série histórica de 25 anos.

A área de estudo foi escolhida a partir da sobreposição de dados, com objetivo de contemplar a expansão da soja no limite da fronteira agrícola. A Figura 5.24 retrata a localização da área de estudo por meio da área das imagens de satélite.

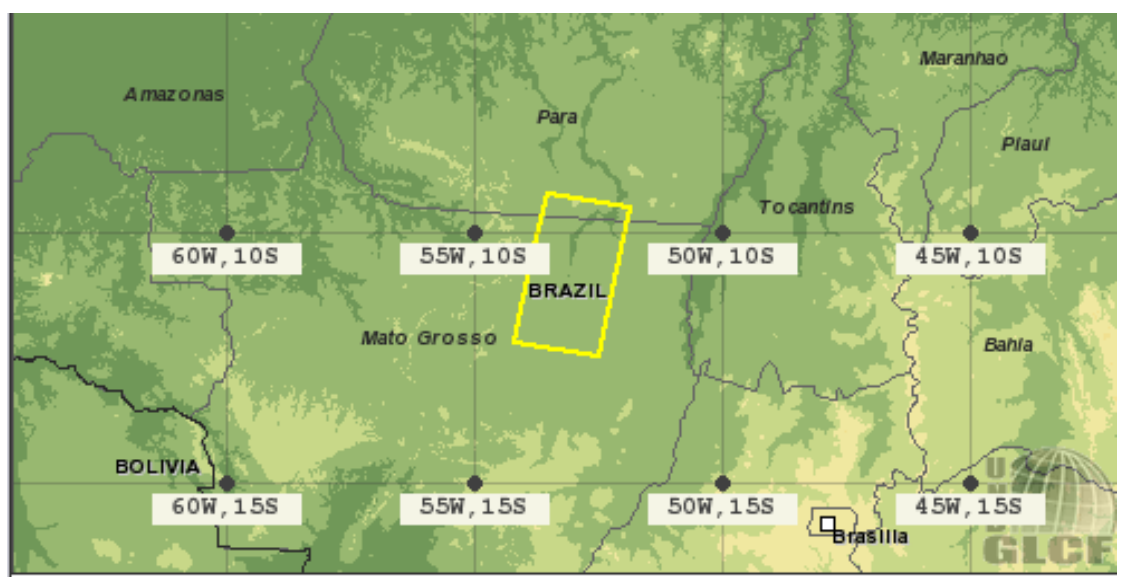

Fonte: http://www.dgi.inpe.br/CDSR

Figura 5.24 - Localização da área de estudo

A partir da carta topográfica digitalizada 1:100.000 de São José do Xingu, as imagens foram interpretadas e as diferentes classes de uso de solo identificadas e definidas: mata nativa, cultura de soja, pecuária e áreas urbanas. Com a análise e classificação das imagens, gerou-se um mapa temático demonstrando a configuração espacial da área de estudo, ou seja, um mapa de uso do solo.

Com a vetorização dos limites pré-estabelecidos na interpretação foi possível a quantificação das áreas em metros quadrados e em hectares. Esses dados trabalhados no Excel deram origem a gráficos comparativos e às porcentagens dos terrenos em cada classe de uso do solo.

A interpretação da imagem de 1984, que está figura 5.25, foi realizada dando origem ao Mapa 2 de uso do solo de São José do Xingu. Esse mapa também contém os dados quantitativo e gráfico que representam as classes de uso do solo. 


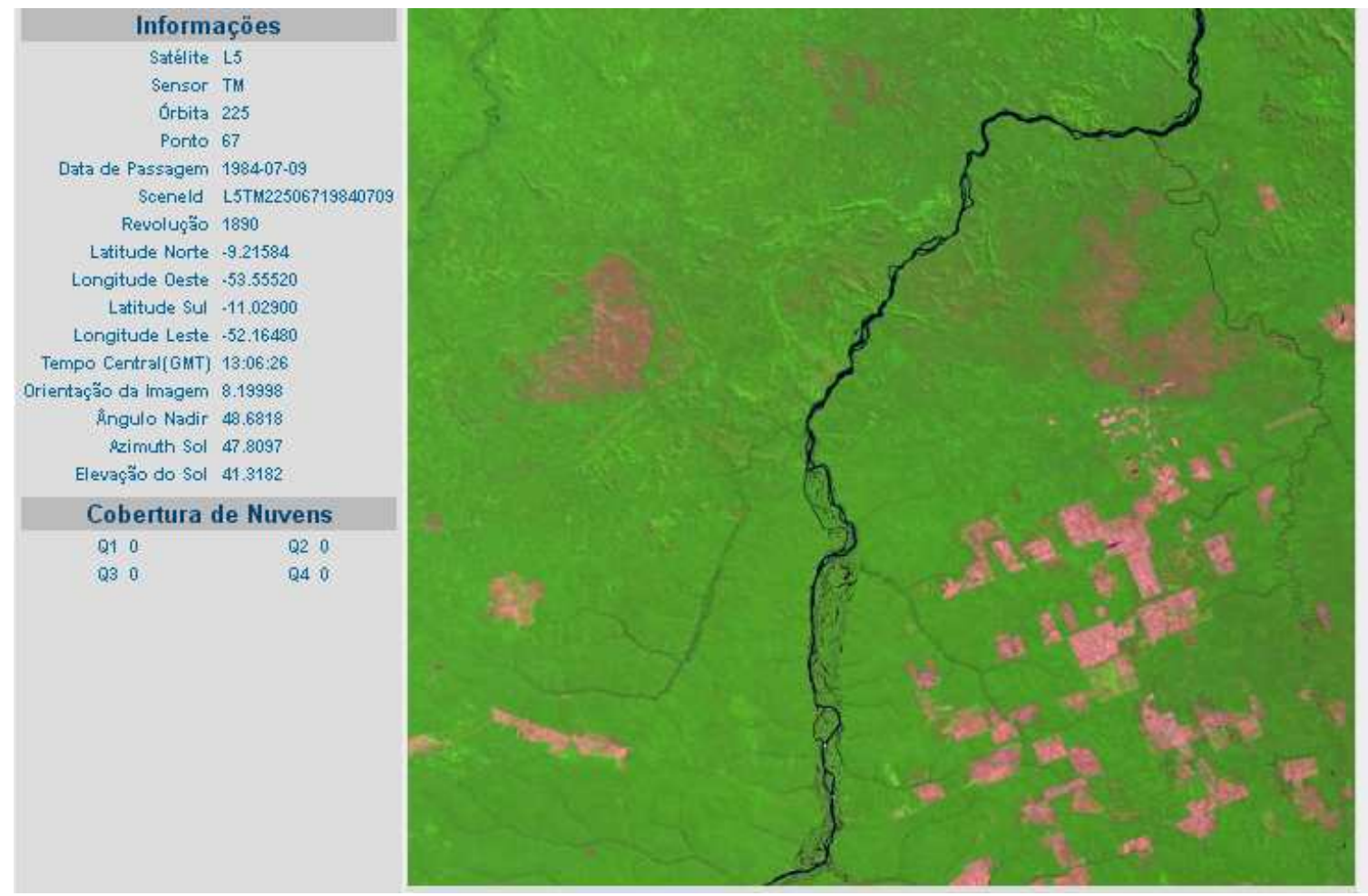

Fonte: http://www.dgi.inpe.br/CDSR

Figura 5.25 - Imagem de satélite de 1984 
Mapa 2 - Uso do Solo de São José do Xingu - 1984

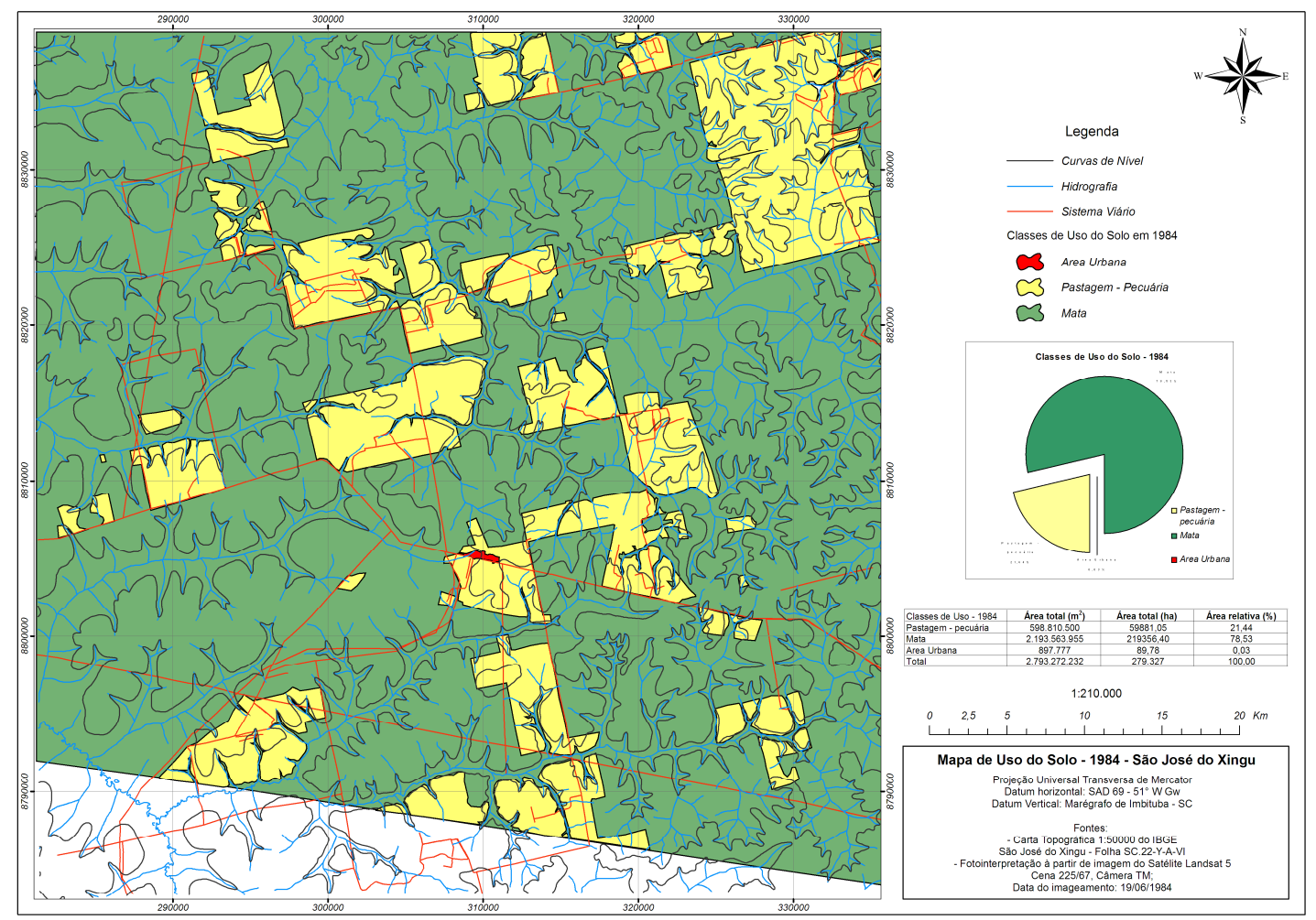


Analisando-se o mapa, podemos concluir que a mata nativa, representada pela Floresta Amazônica, ocupava a maior parte da área estudada, recobrindo cerca de 219.356 hectares, representando $78,53 \%$ da área total analisada.

Somente algumas áreas foram devastadas para prática de pecuária, representando quase 60 mil hectares, ou seja, 21,44\% da área total analisada. A cidade de São José do Xingu está representada pela área urbana que se estendia por apenas 89,78 hectares, representando $0,03 \%$ da área total analisada.

O sistema viário estende-se em algumas porções do mapa, porém há existência apenas de estradas não pavimentadas, ou seja, de terra.

É possível observar também que a maior parte das cabeceiras dos rios ainda encontrava-se recoberta por mata nativa, porém, nas áreas que já se tinha pastagem ocorria o desmatamento de algumas nascentes.

O mapa 3 apresenta o mapa de uso de solo resultado da interpretação da imagem de 1994, que segue adiante como figura 5.26. 


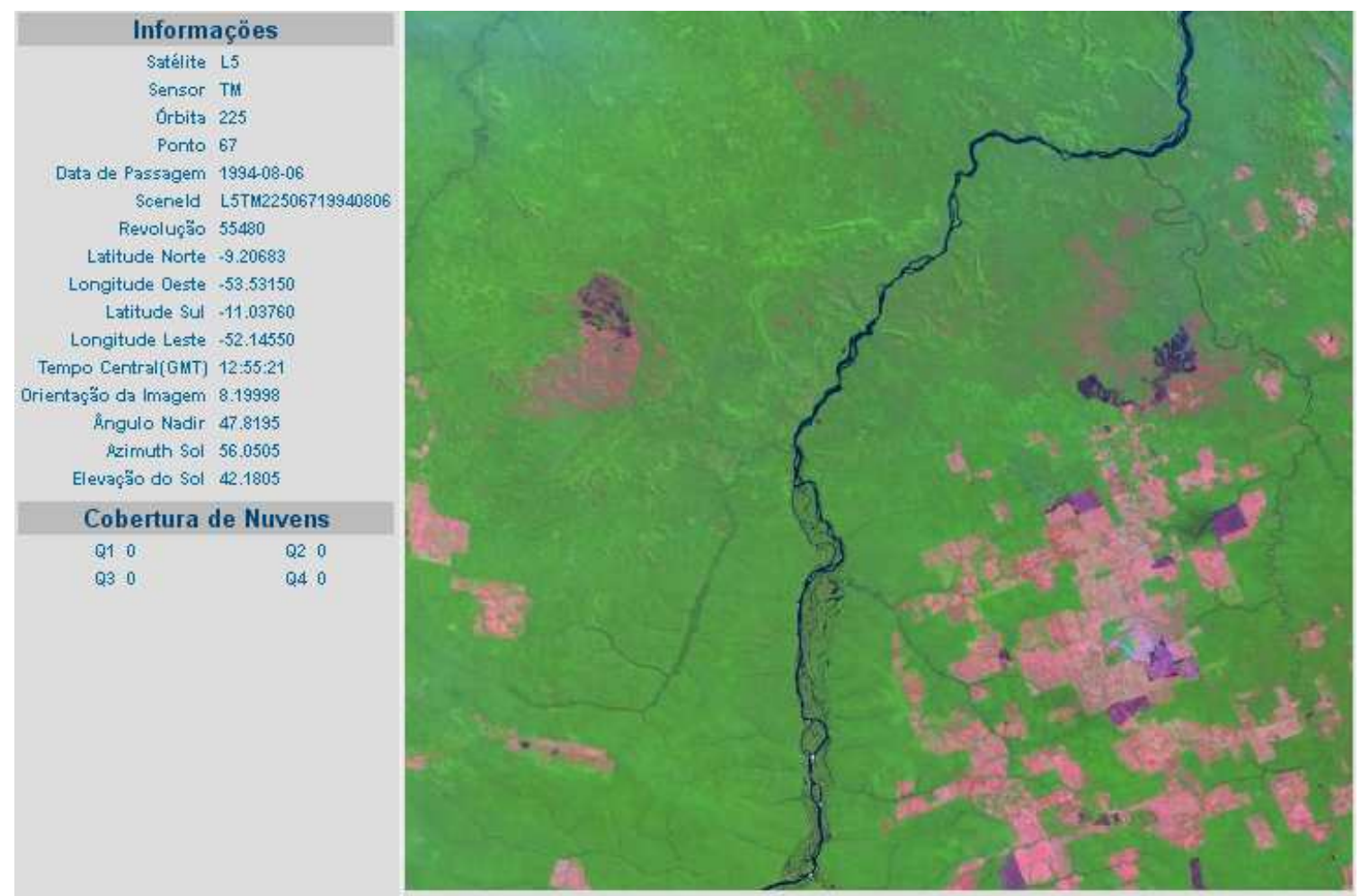

Fonte: http://www.dgi.inpe.br/CDSR

Figura 5.26 - Imagem de satélite de 1994 
Mapa 3 - Uso do Solo de São José do Xingu - 1994

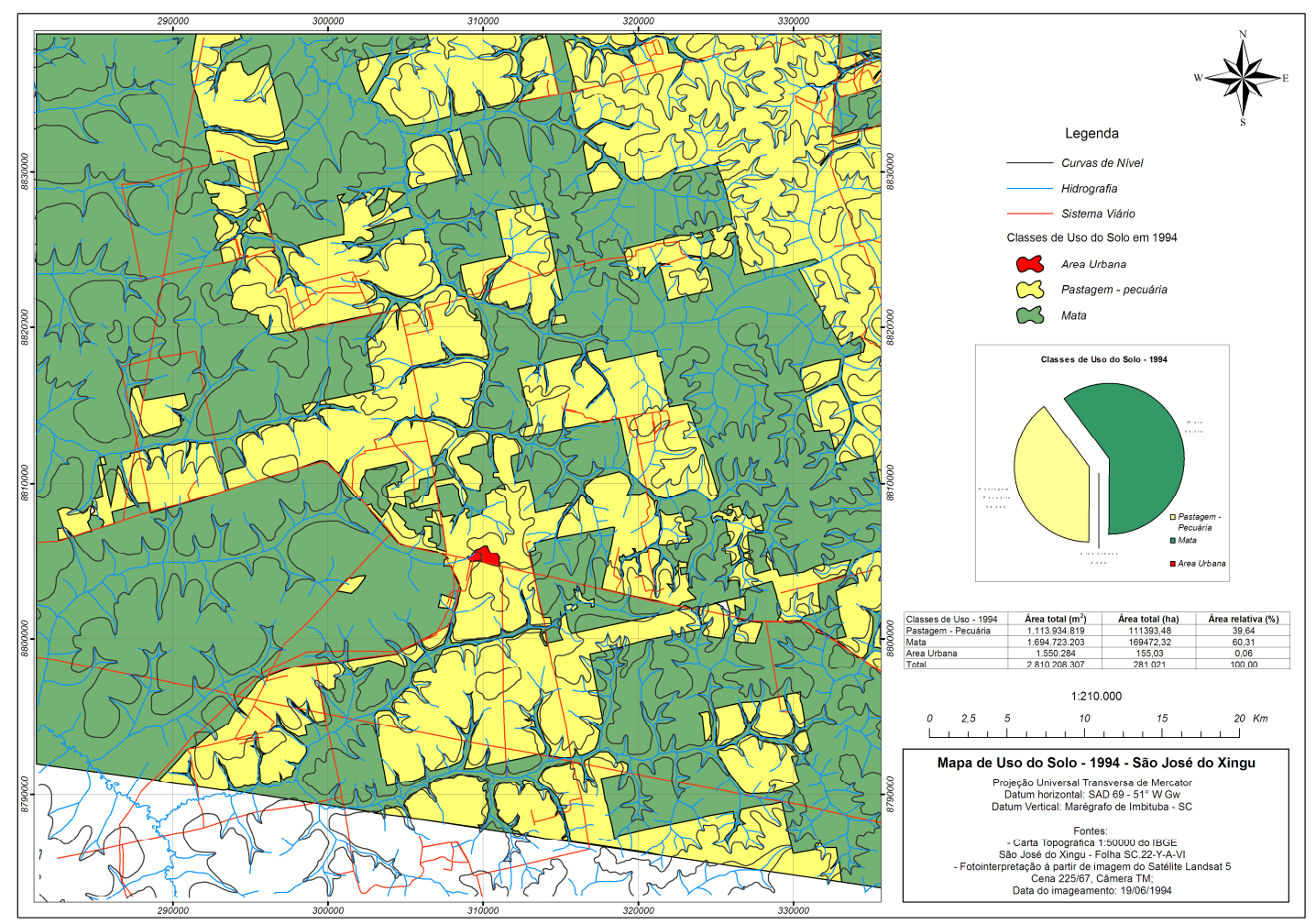


Analisando o mapa 3, é possível notar o avanço da pecuária sobre as áreas anteriormente caracterizadas pela mata nativa. No período de 10 anos houve um acréscimo de 18,22\% de área desmatada e as pastagens passaram a ocupar quase 112 mil hectares, passando a representar 39,64\% da área total analisada.

A Floresta Amazônica, que recobria 78,53\% da área total, passou a recobrir 60,31\%, representados por 169.472 hectares, um decréscimo de quase 50 mil hectares de mata na região no período de 10 anos. Esse desmatamento, como já fora dissertado anteriormente, reflete os estímulos governamentais para ocupação da região a partir de atividades agropecuárias.

No caso da região estudada a criação de gado foi a atividade que predominou para ocupação da região. Cada vez mais o município foi se consolidando como área pecuarista e, como visto anteriormente, esse avanço na década de 80 significou sua maior importância regional e emancipação do município em 1992.

Esse avanço fica bem visível quando analisado no setograma, onde os 60,31\% ficam evidentes quando comparados com o mapa de 1984. No sistema viário não houve praticamente mudanças, e as estradas de terra ainda predominavam no território, mesmo com aumento da ocupação.

Também é possível perceber que nas áreas ocupadas pela pastagem, não houve preocupação em poupar as cabeceiras dos rios, e muitas foram desmatadas. A área urbana também cresceu cerca de $42 \%$ em relação à área ocupada em 1984, representando 155,03 hectares, $0,06 \%$ da área total analisada.

A figura 5.27 mostra a imagem de satélite de 2009, qual deu origem ao Mapa 4 de uso de solo 


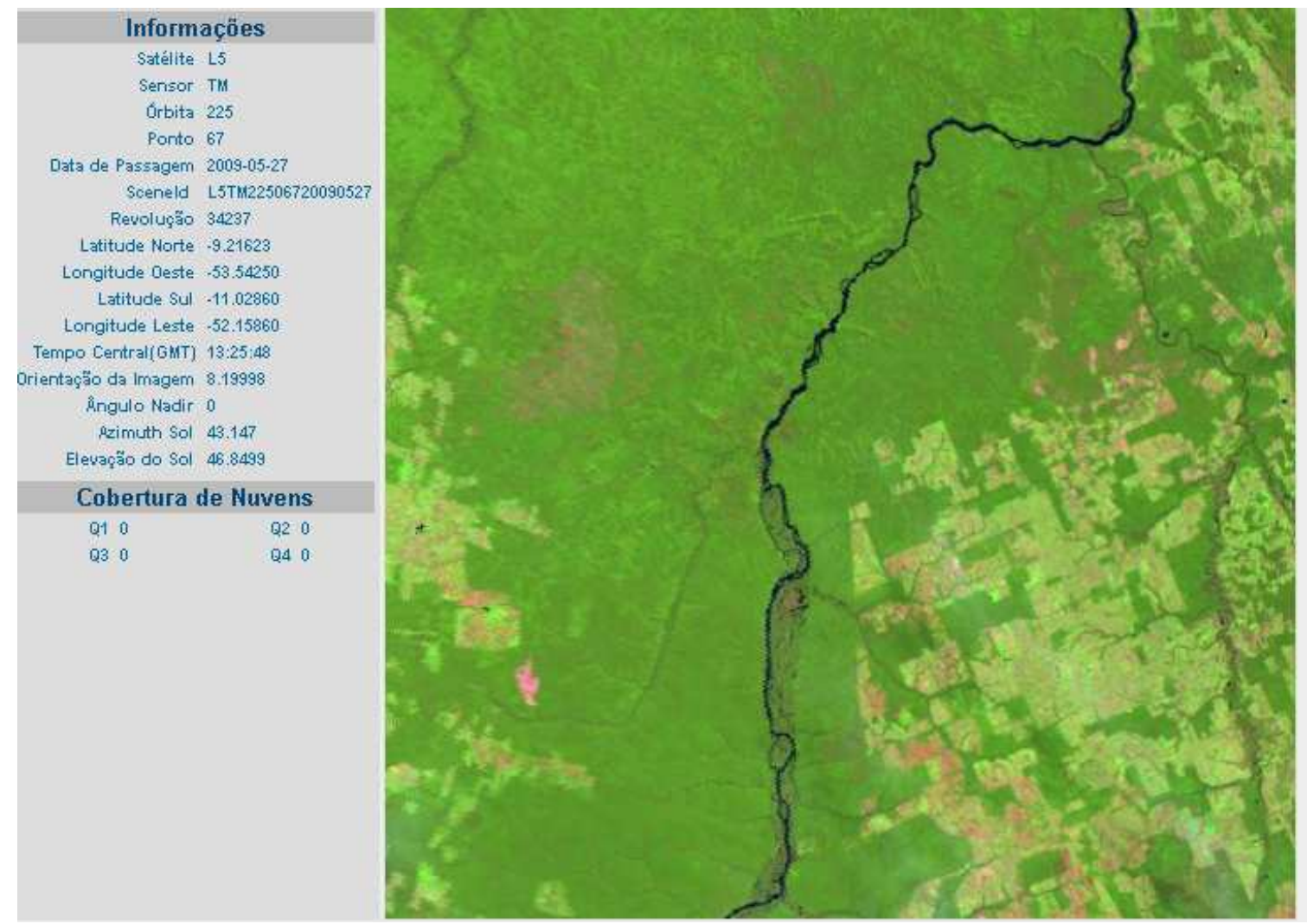

Fonte: http://www.dgi.inpe.br/CDSR

Figura 5.27 - Imagem de satélite de 2009 
Mapa 4 - Uso de Solo de São José do Xingu - 2009.

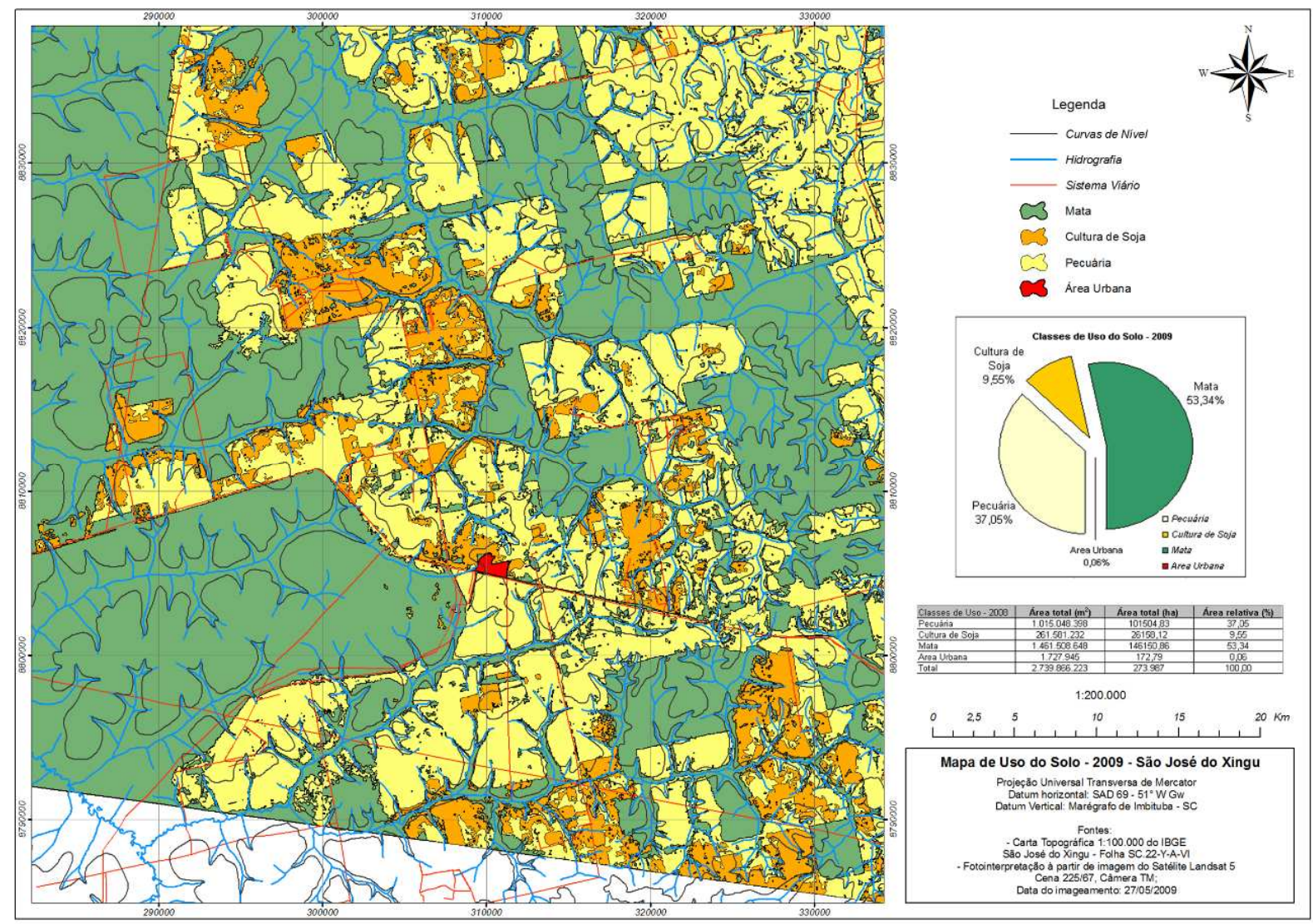


A última imagem de satélite selecionada datava de julho de 2008. Porém, na interpretação não foi possível diferenciar as áreas de cultura de soja e pastagem já que tal período é época de plantio e o solo também a aprecia descampado. Então, para melhor interpretação foi selecionada uma imagem de maio de 2009, onde há diferenciação clara de áreas de pastagem e cultura.

O mapa de uso de solo gerado traz um novo uso na legenda: a cultura de soja. Como pode ser verificado, a soja passou a ocupar áreas antigas de pastagem, ocupando cerca de 26.200 hectares, o que corresponde à $9,56 \%$ da área total analisada. A pecuária passou a ocupar uma área de 101.504 hectares, 9.888 hectares a menos que no ano de 1994, representando 37,05\% da área. Em 1994, a pecuária apresentava-se em 39,64\% do território.

Mas essa redução da pecuária não significou redução no desmatamento. Ainda, algumas áreas antes florestadas foram ocupadas por novos campos de pastagem, e a mata nativa passou a representar 53,34\% da área total, ou seja, 146.150 hectares. Uma diminuição de aproximadamente $7 \%$ se comparado com 1994, e de $25 \%$ se comparado com 1984. Ou seja, o desmatamento na região deu-se em função principalmente da atividade pecuária.

Em relação á área urbana, houve um crescimento que se estendeu por 17,19 hectares a mais que em 1994, ou seja, cresceu cerca de 10\% em relação a ocupação de 15 anos atrás. Porém esse percentual é irrelevante quando comparado com a área total, representando ainda $0,06 \%$.

De qualquer forma, nota-se que o desmatamento avançou consideravelmente no período de 25 anos analisado, representando uma perda de 1/4 da vegetação nativa de 1984 a 2009 . É possível perceber que praticamente $50 \%$ do território analisado está ocupado por atividades antrópicas, restando um pouco mais da metade de Floresta ainda preservada.

Após a elaboração dos mapas de uso de solo, foi feita a pesquisa de campo para conferir as informações obtidas. Em geral, os mapas foram interpretados a fim de permitir contextualizar a região de São José do Xingu como uma área pecuarista. Verificou-se que o município sempre teve a criação de gado como principal atividade econômica da cidade.

Até mesmo sua ocupação e emancipação foi dada diante a importância como área produtora de gado bovino. Logo, o desmatamento está totalmente vinculado à expansão da atividade pecuária. 
De 1984 a 1994, as áreas desmatadas corresponderam a 111.393,48 hectares, ocupadas por pastagens. Um aumento de 18,22\% em 10 anos, uma redução de quase 50 mil hectares de floresta nativa. A Floresta passou a recobrir $60,13 \%$, e as pastagens $39,64 \%$ da área analisada.

Em campo, foi possível obter a explicação para esse percentual alto de desmatamento. Para efetiva ocupação da região norte houve inúmeros estímulos governamentais para desenvolvimento de atividades agropecuárias na região.

A ocupação por pasto ocorria de maneira até mesmo ordenada, já que os terrenos vistos nos mapas são quadriculados e retilíneos. Logo, havia autorização para ocupação dessas áreas. Já a degradação das nascentes dos rios, recorrente em grande parte nos terrenos, era de responsabilidade dos proprietários das fazendas. Mesmo que soubessem da importância da mata ciliar a para o curso do rio, o desmatamento criava açudes para que o gado pudesse matar a sede.

Ainda, na década de 80 e 90, a fiscalização ambiental era falha. Raramente ocorria no local, que é extremamente distante e de difícil acesso. Quando ocorria, o fiscal era facilmente corrompido, havendo desrespeito à lei. Atualmente, diante a fiscalização mais severa e melhores condições aos fiscais, a lei tem que ser respeitada.

A preocupação ambiental também abrange a esfera mercadológica, a partir do momento em que a comercialização do produto é influenciada pelas regras do mercado, que tendem a aceitar somente o que for ambientalmente correto. Dessa forma, muitos proprietários estão regenerando as cabeceiras dos rios identificadas nos mapas como áreas descampadas.

Já a soja só foi incidente na região após 2002. Sua presença no mapa foi dada em 2009, na última imagem, antes, 1984 ou 1994, não havia indícios de soja na região. Atualmente, se estende por uma área de 261.58,12 hectares, representando quase 10\% do território analisado. A pecuária ocupa $37,05 \%$ e a área urbana apenas $0,06 \%$.

Esses dados demonstram que a pecuária configura-se ainda como principal atividade econômica da cidade, entretanto o crescimento do núcleo urbano, que evoluiu de aproximadamente 90 hectares a 173 hectares (quase o dobro em 25 anos), não é representativo quando avalia-se a área total do estudo, já que ocupa apenas $0,06 \%$.

Praticamente não há grande expressividade do desmatamento vinculado ao aumento populacional e urbano de São José do Xingu. Apesar do baixo crescimento relativo ao longo 
dos anos, o município possui pouca infra-estrutura e configura-se como o centro comercial de maior importância em um raio de $200 \mathrm{~km}$ das fazendas produtoras, seja de soja ou gado

A soja apresentou-se como cultivo relativamente novo, com pequena expressividade, mas importante fonte de renda. Mesmo porque, como verificado em campo, há potencialidade da região para essa cultura devido às condições favoráveis de solo e clima. Porém, não há destino dessa cultura para o biodiesel.

Mesmo com algumas usinas de biodiesel existentes no norte do Mato Grosso, a produção de soja sofre entraves logísticos devido ás péssimas condições de acesso e custo do frete, sendo totalmente direcionadas a empresas transnacionais da região, e posteriormente, ao mercado externo. 


\section{CONCLUSÕES}

Conforme exposto na Introdução desse trabalho, foi proposto fazer uma avaliação histórica mais recente da soja como matéria-prima para o biodiesel, buscando-se analisar as potencialidades agrícolas da soja por região produtiva e os efeitos ambientais que serão gerados em razão dessa cultura.

Notadamente, a soja nos apareceu como matéria-prima de maior expressividade para produção de biodiesel. Além de cultura consolidada no território brasileiro desde a década de 70, domínio tecnológico conhecido para produção de biodiesel e logística favorável, a soja atendeu às exigências do PNPB desde o início, sendo possível aumentar a porcentagem de adição de biodiesel ao diesel.

Contudo, novas matérias-primas devem ser estimuladas. Algumas culturas podem atender o mercado com maior rendimento de óleo/hectare e com incentivo à agricultura familiar no campo havendo efetivamente uma inclusão social.

Como, por exemplo, o óleo de algodão que pode representar uma alternativa para produção de biodiesel, já que seu uso para consumo é limitado, não sendo efetivamente útil, e é também um resíduo dessa matéria-prima. A Região Centro-Oeste apresenta produção de algodão, e poderia representar fonte de renda à Região Nordeste, que também tem cultivo de algodão significativo.

Algumas palmáceas também apresentam maior rendimento por hectare, como a macaúba, dendê, babaçu, entre outros, podendo representar fonte de renda para certas áreas brasileiras.

Também, como comentado anteriormente, o Programa Nacional de Produção e Uso de Biodiesel teve um início abrupto, não sendo possível a definição de ações e estratégias por parte do governo. A construção do Programa não foi regulada pelo mercado como acontece com o etanol.

Para que o PNPB se consolide há necessidade de políticas públicas que considerem as dotações regionais e as culturas melhores adaptadas, a infra-estrutura existente e, assim como a garantia da produção/distribuição do biodiesel em todas as regiões brasileiras. É necessário criar cargas tributárias diferenciadas, estimulando a competitividade; assegurando a regulamentação da produção do biodiesel, visando padronização e garantia de qualidade. 
Além disso, a construção da cadeia produtiva do biodiesel pensada em sistemas tradicionais e pouco tecnificados, não estimulam os pequenos produtores. É importante que haja implementação de políticas que promovam a formação de cooperativas que atuem em todos os estágios da produção, agregando valor ao produto e gerando melhores empregos.

Logo, para melhor atender o mercado e seus objetivos, pesquisas sobre matériasprimas variadas devem ser estimuladas para que possam atender as premissas de produção em pequenas propriedades e estimular a agricultura familiar.

O modo de produção típico da soja não estimula a fixação do homem ao campo e não agrega valor à produção, visto que é uma cultura preponderantemente monocultora e contrata pouca mão-de-obra por ser tipicamente mecanizada, modernizada, com uso de sementes melhoradas geneticamente e fertilizantes, em grandes propriedades e que favorecem a concentração de terras.

Sem dúvida, essa prática expulsa a população do campo, levando o aumento do êxodo rural e crescimento desordenado das cidades. As grandes empresas ocupam espaços no campo antes ocupado por culturas diversificadas e familiares, reduzindo os postos de trabalho e, podem, até mesmo, intensificar os conflitos de terra locais.

Como se não bastasse, seu cultivo direciona-se principalmente para o mercado exterior, por meio de empresas transnacionais que controlam o beneficiamento do grão. Essa prática e a competitividade com fazendeiros estrangeiros deprimem o preço da soja diminuindo a margem de lucro, acabando por gerar menos receita por tonelada produzida.

Dessa forma, os fazendeiros são engolidos pelas grandes fazendas corporativas, que podem compensar as margens menores por tonelada produzindo volumes maiores. E a rede de empresas de soja se associam, formando vários grupos de empresas que verticalizam a produção. Portanto, apesar de sua logística e potencial, a soja não trata-se da melhor cultura para atender os princípios do PNPB.

Além da criação de novas relações de trabalho no modo de produção, há atributos ambientais envolvidos para produção dessa planta para fins energéticos e suas conseqüências. Os impactos do seu cultivo envolvem: compactação e impermeabilização dos solos pelo uso intensivo de máquinas agrícolas; erosão; contaminação por agrotóxicos nos solos e água; aparecimento de novas pragas e; a substituição da mata nativa de áreas contínuas extensas. 
Em relação à substituição da mata nativa, este trabalho verificou, especificamente, seu avanço sobre a área de fronteira agrícola ao norte do país ocupada pela Floresta Amazônica. Foi possível observar que a atividade responsável pelo desmatamento e que tem avançado sobre o arco de deflorestamento é a pecuária.

A soja tem ocupado as áreas de pastos degradados, para até mesmo prover a recuperação dos nutrientes do solo. Por meio da rotação de culturas, a palha do milhete ou sorgo tem agregado matéria orgânica ao solo e evitado a erosão, funcionando como adubo natural. Ainda, cabeceiras de rio desmatadas tem sido restauradas e algumas APPs recuperadas com o que mais se aproxima da mata nativa, na tentativa de uma re-consolidação do ambiente.

Portanto, apesar de impactos ambientais envolvidos no plantio da soja, seu avanço não tem gerado o desmatamento, ao menos não diretamente. Pois, com a ocupação dos pastos degradados, é possível que as áreas de pastagem avancem sobre a floresta.

Apesar da conscientização ambiental, percebe-se que a preocupação dos produtores está muito mais ligada à produção e venda do boi ou grãos que efetivamente com o meio ambiente. Isso porque as certificações ambientais devem ditar o mercado de venda e compra de produtos, que só serão aceitos se produzidos adequadamente, em respeito à lei e ao meio ambiente. O mercado está começando a se preocupar não só com o produto final, carne ou grão, mas como ele foi produzido.

Em relação a evolução da área plantada na região do estudo de caso, avaliou-se que a área coberta por Floresta nativa reduziu, de 1984 a 2009, aproximadamente, 1/4. Recobria cerca de 220 mil hectares da área estudada, representando 78,53\%, e passou, no período de 25 anos a recobrir aproximadamente 147 mil hectares, 53,34\%.

Sua substituição foi dada pela atividade pecuária, que, nesse mesmo período, passou de quase 60 mil hectares $(21,44 \%)$ a cerca de 102 mil hectares $(37,05 \%)$. A soja só apareceu somente no último mapa, no uso de solo de 2009 já que foi incidente na região somente a partir de 2002. Apresentou-se em 10\% da área estudada, cobrindo 26.158 hectares.

Já a cidade teve um crescimento percentual pequeno de $0,03 \%$ no período de 25 anos. Evoluiu de uma ocupação de 90 hectares para 172 hectares, quase duplicando seu tamanho. Porém, em um período longo de tempo, e representando pouco no contexto geral, não sendo responsável pelo desmatamento da região. 
Esse crescimento da cidade está vinculado principalmente a expressividade da atividade pecuária na região. Apesar do potencial agrícola, os entraves logísticos acabam não favorecendo os plantios, já que o gado apresenta-se como atividade economicamente rentável e com menores riscos para o produtor, pois seus preços não oscilam tanto no mercado.

A maior parte das estradas que ligam o município a outras regiões são de terra, de difícil acesso e, ainda, propensas a alagamentos em época chuvosa (de setembro a maio), que acarretam até o isolamento da cidade. Logo, os custos do frete são altos, representando de 20 a $30 \%$ dos gastos do produtor.

Além dos entraves com transporte, há gastos com adubos e corretivos de solo, como o calcário, e a probabilidade de perda da produção diante algum evento climático não esperado. Também o preço da soja pago às fazendas é determinado diretamente pelo preço do produto no mercado internacional, e sua queda nos preços do grão, como ocorreu em 2004, desmotiva a produção agrícola na região.

É nesse sentido que, a produção de soja de São José do Xingu está totalmente vinculada às empresas transnacionais. Como não há beneficiadoras de grãos na região, a soja apresenta baixo valor agregado e seu principal destino são as secadoras mais próximas, como a Cargill, que localiza-se a $35 \mathrm{~km}$ do município, e a Bunge, a $70 \mathrm{~km}$.

A usina de biodiesel mais próxima está localizada em Porto Alegre do Norte, cerca de 200 km de distância de São José do Xingu, o que inviabiliza a produção de soja de São José do Xingu para tal fim, não apresentando, a curto prazo, potencialidade para produção de biodiesel.

Já a produção de biodiesel nas outras cidades do norte do Mato Grosso, como Sinop, Colíder e outras, apresenta expressividade porque há necessidade da Petrobrás em adir $4 \%$ de biodiesel ao diesel comum, comprando o insumo nos leilões e retirando-os no local. Entretanto, com a abertura das vendas, essa produção deverá atender a um mercado regional devido à distância do centro consumidor e os gastos com transporte do biodiesel.

Mas a soja não precisa ser a única matéria-prima fonte de biodiesel para atender o mercado regional. A associação com o sebo bovino pode ser uma alternativa visto que a região Centro-Oeste é a maior produtora do país também de gado bovino. Sendo a carne ou couro direcionado ao mercado interno ou à exportação, o sebo é um subproduto que pode ser valorizado sendo utilizado no consorciamento da produção biodiesel com a soja, assim como já ocorre em Colíder na usina CLV. 
Portanto, mesmo que, a longo prazo, São José do Xingu venha a ter melhor acesso pelas estradas e rodovias, com asfaltamento e condições viáveis de tráfego, sua produção de soja não deverá destinar-se ao biodiesel, já que outras empresas deverão consolidar-se no norte do Mato Grosso e atenderiam a demanda desse mercado regional. 


\section{REFERÊNCIAS BIBLIOGRÁFICAS}

AB’SABER, A. N. Amazônia: do discurso a práxis. São Paulo: Edusp, 2004.

ARBEX JR. J. Terra sem povo, crime sem castigo: pouco ou nada sabemos de concreto sobre a Amazônia In: TORRES, M. (Org). Amazônia Revelada: os descaminhos ao longo da BR 163. Brasília : CNPq, 2005.

ARVOR, D., et al. Análise dos perfis temporais de EVI/MODIS para o monitoramento da cultura da soja no estado de Mato Grosso, Brasil. In: SIMPÓSIO BRASILEIRO DE SENSORIAMENTO REMOTO, 13. Florianópolis (SC). Anais. Florianópolis: INPE, 2007, p. 51-58.

ASSAD, M.L.L. Conservação de Solos e Biodiversidade. In: BENSUSAN, N.(Org): Seria Melhor Ladrilhar? : biodiversidade: como, para que, por quê. São Paulo : Editora da Universidade de Brasília , 2008

BARRETO, C. A. Os Impactos Socioambientais do cultivo de soja no Brasil. Disponível em Disponível em: :<http://www.anppas.org.br/encontro_anual/encontro2/GT/GT05/clarissa_barreto.pdf> Acesso em: 10 ago. 2009.

BATISTA, P. N. O desafio brasileiro: a retomada do desenvolvimento em bases ecologicamente sustentáveis. Política externa. São Paulo. v.2, n.3, 1994,

BERMANN, C. (Org) As novas energias no Brasil: dilemas da inclusão social e programas de governo. Rio de Janeiro : FASE, 2007.

BERMANN, C. (Org). Desafios e Perspectivas dos agrocombustíveis no Brasil: a agricultura familiar face ao etanol da cana-de-açúcar e ao biodiesel da soja, mamona e dendê. In: Agrocombustíveis e Agricultura Familiar e Camponesa: subsídios ao debate. Rio de Janeiro: FASE, 2008.

BONALUME, W. L. Os biocombustíveis poderiam afetar a produção de alimentos? São Paulo . Revista Biodiesel, n. 20. , set. , 2007.

BRANDÃO, A. et al. Crescimento agrícola no Brasil no período 19992004: explosão da soja e da pecuária bovina e seu impacto sobre o meio ambiente. Rio de Janeiro : IPEA, jul. 2005. 
BRASIL.Ministério de Agricultura, Pecuária e Abastecimento. Balanço anual da cana-deaçúcar e agroenergia: 2007. Brasília, 2007

BRASIL. Ministério de Agricultura, Pecuária e Abastecimento. Anuário Estatístico da Agroenergia, 2009. Brasília, 2009

BRASIL.Ministério de Minas e Energia. Balanço Energético Nacional: 2005. Rio de Janeiro, 2006, 188p.

CAFEZEIRO, M.L. Reflexões sobre a pequena produção familiar e o biodiesel no Estado do Mato Grosso, no Brasil. In: Encuentro de Geógrafos de América Latina, 12., 2009, Montevideo, Uruguay. EGAL. Proceedings.

CASTRO, F. Intensifica-se o debate. Disponível em: <http://www.biodieselbr.com/noticias/energia/intensifica-se-debate-10-05-07.htm>.

Acesso em: 10 jun. 2007.

CHIARANDA, M. A produção de biodiesel no Brasil e os aspectos levantados no programa nacional. São Paulo : Edusp, 2005.

COELHO, Jorge Cals. Biomassa, Biocombustíveis, Bioenergia. Brasília : Ministério de Minas e Energia, 1982. In: COELHO, Suani T. (Org). Panorama do potencial de biomassa no Brasil. Brasília : Dupligráfica, 2003.

COHENCA, D. A expansão da fronteira agrícola e sua relação com o desmatamento detectado em imagens Landsat TM e ETM+, na região norte da BR-163, Pará, entre os anos 1999 a 2004. Monografia.- Departamento de Ciências Florestais da Universidade Federal de Lavras, dez/2005.

COMPANHIA NACIONAL DE ABASTECIMENTO. Intenção de plantio da safra de grãos Natal $(R N)$ : MAPA/Superintendência Regional do Rio Grande do Norte, Gerência de Operações e Suporte Estratégico GEOSE, Setor de Apoio à Logística e Gestão da Oferta SEGEO, fev/ 2005.

COSTA, Antônio; YAMAOKA, Ruy Seiji \& COSTA, Marco Aurélio Teixeira. Matérias Primas para Produção de Biodiesel. In: SEMINÁRIO SOBRE A PRODUÇÃO E USO DE BIODIESEL NA BACIA DO PARANÁ, 3., 2006, Curitiba . Anais.

COSTA NETO, Pedro R. et al. Produção de Biocombustível Alternativo ao Óleo Diesel Através de Transesterificação de Óleo de Soja Usado em Frituras. Curitiba :- CEFETUniversidade do Paraná, 1999. 
CUNHA, A. S. (coord.) Uma avaliação da sustentabilidade da agricultura nos cerrados. Brasília: IPEA, 1994.

DOMINGUES, Mariana Soares; DAMASCENO, Marcos Paulo Simões. Análise da utilização das oleaginosas-dendê, mamona e soja para viabilidade de implantação do Programa Nacional de Produção e uso do Biodiesel - PNPB. 2008. 108p. Monografia (Especialização em Gestão Ambiental ) - Instituto de Eletrotécnica e Energia da Universidade de São Paulo, São Paulo, 2008.

EMPRESA MATO-GROSSENSE DE PESQUISA. Assistência e Extensão Rural. Apresentação de Estudo de realidade de São José do Xingu (MT). Empaer, 2009.

EMPRESA BRASILEIRA DE PESQUISA AGROPECUÁRIA. Tecnologias da Produção de Soja na região central do Brasil. Embrapa, 2004. Disponível em: <http://www.cnpso.embrapa.br/producaosoja/SojanoBrasil.htm>. Acesso em: 10 ago. 2009.

FOOD AND AGRICULTURE ORGANIZATION OF THE UNITED NATIONS. . Food and Agricultural commodities production. Disponível em:

http://www.fao.org/es/ess/top/commodity.html;jsessionid=051B3E79C2FD549C004A923 53A80DEEC?lang=en\&item=156\&year=2004. Acesso em: 10 jun. 2007.

FÓRUM BRASILEIRO DE ONGS E MOVIMENTOS SOCIAIS PARA MEIO AMBIENTE E DESENVOLVIMENTO. Relação entre cultivo da soja e desmatamento: compreendendo a dinâmica. 2005. Disponível em:

<http://www.socioambiental.org/inst/docs/inst/docs/download/soja.pdf.> Acesso em : 10 jun. 2007.

FERRARI, Roseli Aparecida; OLIVEIRA, Vanessa da Silva \& SCABIO, Ardalla. Biodiesel de Soja: taxa de conversão em esteres etílicos, caracterização físico-química e consumo em gerador de energia. Ponta Grossa ,PR : Departamento de Engenharia de Alimentos da Universidade Estadual de Ponta Grossa, 2003.

FERREIRA, Cláudio B. Biodiesel. In: COELHO, Suani T. Parcerias para o desenvolvimento tecnológico e industrial em ecoenergia. São Paulo: CENBIO , 1998.

FISCH,G. Implicações Microclimáticas dos Processos de Superfície e da Camada Limite na Amazônia devido ao Desmatamento de Floresta Tropical. São José dos Campos: INPE, 2006. 
FLORENZANO, T. G. Imagens de satélite para estudos ambientais. São Paulo: Editora Oficina de Textos, 2002.

FONTANA, R. Viabilidade do uso do biodiesel no meio rural . Monte Alto, SP, Revista Biodiesel, n. 20, set., 2007.

GALLINKIN, M. Uso de instrumentos econômicos para defesa do Bioma Cerrado. ISA, 2008, Disponível em :<http://www.socioambiental.org/esp/soja/(vários).shtm.> Acesso em: 10 jun. 2009.

GOLÇALVES, C.W.P. Amazônia, Amazônias. São Paulo: Contexto, 2005.

GREENPEACE. Eating $U p$ the Amazon.. Disponível em: <http://www.greenpeace.org/international/press/reports.> Acesso em: 10 jun.2007.

GÖRGEN, S. A. Os novos desafios da agricultura camponesa. Porto Alegre : Editora Vozes, 2004.

GREENPEACE. Eating $U p$ the Amazon. Disponível em : <http://www.greenpeace.org/international/press/reports.> Acesso em 10 jun. 2007.

HAWEIL, B. Que fim levaram os fazendeiros? Revista Worldwatch, nov. 2005.

Disponível em: < http://www.wwiuma.org.br/qfim_levaram_faz.htm.> Acesso em : 10 jun. 2007.

HOLANDA, Ariosto. Biodiesel e Inclusão Social. Brasília : Conselho de Altos Estudos e Avaliação Tecnológica da Câmara dos Deputados, 2004.

HOMMA, Alfredo Kingo Oyama. Amazônia: como aproveitar os benefícios da destruição? . Revista Estudos Avançados, São Paulo, v.19, n. 54, p. 115 a 135, ago. 2005.

INSTITUTO BRASILEIRO DE GEOGRAFIA E ESTATÍSTICA. Matriz de InsumoProduto Brasil 1996. Rio de Janeiro, 1997.

INSTITUTO DE DEFESA AGROPECUÁRIA. Informações obtidas na sede de São José do Xingu - MT. Porto Alegre do Norte; MT: INDEA, 2009.

LEONEL, M. A morte social dos rios. São Paulo: Perspectiva: Instituto de Antropologia e Meio Ambiente: FAPESP, 1998. 
LOPES ASSAD, M.L . Conservação do Solo e Biodiversidade. In: Nurit Bensusan. (Org.). Seria melhor mandar ladrilhar? Biodiversidade: como, para que e por quê. 2.ed. Brasília: Editora Peirópolis e Editora da Universidade de Brasília, 2008. p. 1-428.

MACEDO, I. C.; NOGUEIRA H. A. L. Avaliação do biodiesel no Brasil. Brasília : Núcleo de Assuntos Estratégicos da Presidência da República, 2005. 233 p.

MEIRELLES, Fabio de Salles. O Biodiesel no Brasil e seus impactos sobre agricultura. São Paulo : Federação da Agricultura do Estado de São Paulo, 2005.

MOTTA, R. S. M.; et al O Custo Econômico do Fogo na Amazônia. Rio de Janeiro: IPEA, 2002.

MÜLLER-PLATENBERG, C. ; AB'SABER, A. N.(Orgs). "Previsão de Impactos". São Paulo : Edusp, 2006.

MUELLER, C. A sustentabilidade da expansão agrícola nos cerrados. Instituto Sociedade, População e Natureza. Documento de Trabalho n.36, 1995. (mimeo).

MUELLER, C. et al. Análise da expansão da soja no Brasil. Brasília : Banco Mundial, abr. 2002. versão preliminar.

NOVAES, W. Agenda 21 brasileira: bases para discussão. Brasília: MMA-PNUD, 2000.

NOVO, Evelyn M. L. de Morais. Sensoriamento Remoto, Princípios e Aplicações. São José dos Campos , 1988.

NUCLEO DE ASSUNTOS ESTRATÉGICOS DA PRESIDÊNCIA DA REPÚBLICA Biocombustíveis. Brasília : NAE, 2005.

OLIVEIRA, A.U. BR-163 Cuiabá-Santarém: Geopolítica, grilagem, violência e mundialização. In: TORRES, M. (Org). Amazônia Revelada: os descaminhos ao longo da BR 163. Brasília:CNPq, 2005.

ORTIZ, L. (Coord). Agronegócio + Agroenergia:impactos cumulativos e tendências territoriais da expansão das monoculturas para produção de bioenergia. Rio de Janeiro: FBOMS, 2006.

ORTIZ, L. \& RODRIGUES, D. Biocombustíveis com mais sustentabilidade. In: ORTIZ, L. (Org.) Agronegócio + Agroenergia: impactos cumulativos e tendências territoriais da expansão das monoculturas para a produção de bioenergia. Brasília : FBOMS, 2006. 
PEREIRA, M.N.; KURKDJIAN, M.L.N.O.; FORESTI C.Cobertura e uso da Terra através de Sensoriamento Remoto. Dissertação (Mestrado em Sensoriamento Remoto) Instituto Nacional de Pesquisas Espaciais. São José dos Campos, 1989.

SACHS, I. Estratégias de transição para o século XXI. In: BURSZTYN, M. (Org.) Para pensar o desenvolvimento sustentável. São Paulo: Brasiliense, 1994. p.29-56.

SANCHEZ, R., SHIMABUKURO, M. ; BARRETTO, R. O Xingu na mira da soja. São Paulo: Instituto Socioambiental, $2003 . \quad$ Disponível em:<htpp://www.socioambiental.org.br>. Acesso em: 20 nov. 2003.

SCHLESINGER, S. (Org) . Agronegócio e Biocombustíveis: uma mistura explosiva. Rio de Janeiro: FBOMS, 2006.

SCHLESINGER, S ; NORONHA, S. O Brasil está nu!: o avanço da monocultura da soja, o grão que cresceu demais. Rio de Janeiro: FASE, 2006.

SCHLESINGER, S. O grão que cresceu demais: a soja e seus impactos sobre a soja e o meio ambiente. Rio de Janeiro :FASE, 2006.

SANTOS, M. Por uma outra globalização: do pensamento único à consciência universal. São Paulo : Record, 2000.

SANTOS, C.V. ; COELHO R.A.S. My City has history: São José do Xingu (MT). Fat Cattle Capital. Realização Fazenda Bang - Programa de desenvolvimento sustentável do grupo Pão de Açúcar, dez. 2008.

SEVÁ F, A.O.(Org). Tenotã-Mo: Alertas sobre as conseqüências dos projetos hidrelétricos no rio Xingu. Berkeley, Ca.: Editora IRN, 2005.

TORRES, M. (Org). Amazônia Revelada: os descaminhos ao longo da BR 163. Brasília : CNPq, 2005.

VEIGA, J. E. A insustentável utopia do desenvolvimento. In: LAVINAS, L. (Org.) Reestruturação do espaço urbano e regional no Brasil. São Paulo: HUCITEC/ANPUR, 1993. p.149-169.

VIDAL, J.W. Bautista. Soberania e dignidade: raízes da sobrevivência. Rio de Janeiro: Vozes, 1991.

WAGNER A. et al. Estimativa de área de soja no Rio Grande do Sul utilizando imagens NDVI/ MODIS. In: Simpósio Brasileiro de Sensoriamento Remoto, 13., 2007. Florianópolis . Anais : São José dos Campos: INPE, 2007. p. 457-464. 
YUUKI, Paulo Yoshiro. Avaliação dos impactos econômicos da produção do biodiesel no Brasil. Brasília: Sober, 2005.

O que (des)mata nossa Amazônia. São Paulo, Revista Brasileira de

Bioenergia, v.1, n.1, mar., 2007.

\section{$\underline{\text { Sítios da web consultados }}$}

ANP - Agência Nacional do Petróleo. http://www.anp.gov.br/petro/dados_estatisticos.asp, $\mathrm{abr} / 2008$.

ABIODIESEL Associação Brasileira das Indústrias de Biodiesel. Disponível em http://www.biodieselbr.com. Acesso em 21/09/2006.

CONAB - Companhia Nacional de Abastecimento - www.conab.gov.br, jan/2008.

DESER Desenvolvimento de Estudos Socioeconômicos Rurais. Disponível em http://www.deser.org.br. Acesso em 21/09/2006.

DNIT - Departamento Nacional de Infra-estrutura de Transportes. www.dnit.gov.br. Mapa do Estado do Mato Grosso. Acesso em set/2009.

EMBRAPA - Empresa Brasileira de Pesquisa Agropecuária. www.cnpa.embrapa.br, set./2006.

GREENPEACE - www.greenpeace.com.br, jun/2006.

IAC Instituto agronômico de Campinas disponível em http://www.iac.sp.gov.br, ago/2006.

IBAMA Instituto Brasileiro de Meio Ambiente e Recursos Naturais Renováveis.

Disponível em http://www.ibama.gov.br/ecossistemas/ Acesso em ago/2006

ISA Instituto Socioambiental. Disponível em

http://www.socioambiental.org/esp/soja/(vários).shtm. Acesso em 10/06/2007

IPEA - Instituto de Pesquisa Econômica Aplicada - Disponível em

http://www.ipea.gov.br. Acesso em nov/2007. 
FBOMS Fórum Brasileiro de ONGs e Movimentos Sociais para o Meio Ambiente e o Desenvolvimento. Disponível em http://www.fboms.org.br. Acesso em 10/06/2007.

MMA Ministério do Meio Ambiente. Disponível em http://www.mma.gov.br/. Acesso em jun/2008

NCGA National Corn Growers Association. Disponível em

http://europa.eu/scadplus/leg/en. Acesso em 15/05/2007.

PORTAL DO BIODIESEL - GOVERNO FEDERAL - www.biodisel.gov.br, out/2006.

PORTAL O GLOBO. Disponível em http://g1.globo.com. Acesso em 14/05/2007.

SECRETARIA DA AGRICULTURA, IRRIGAÇÃO E REFORMA AGRÁRIA DA BAHIA. Disponível em http://www.seagri.ba.gov.br/RevBaAgr/ rev_112000/agribusdende.htm. Acesso em 28/10/2006.

TN Brasil - http://www.tnbrasil.com.br/cidades/sorriso.asp - Acesso em out/2009.

WORLDWATCH INSTITUTE Disponível em http://www.wwiuma.org.br. Acesso em $10 / 06 / 2007$. 


\section{ANEXOS}

Anexo 1 - Projeto de Lei No 3.368 / 2004 - Dispões sobre a obrigatoriedade da adição de dois por cento de biodiesel ao óleo diesel, sobre o cultivo de oleaginosas a serem utilizadas na fabricação de biodiesel e sobre a sua produção

Anexo 2 - Lei $N^{\circ}$ 11.097, de 13 de janeiro de 2005 - Dispõe sobre a introdução do biodiesel na matriz energética brasileira; altera as Leis $\mathrm{n}^{\mathrm{os}}$ 9.478, de 6 de agosto de 1997 , 9.847 de 26 de outubro de 1999 e 10.636, de 30 de dezembro de 2002 e dá outras providências 


\section{ANEXO 1}

Projeto de Lei No 3.368 / 2004 - Dispõe sobre a obrigatoriedade da adição de dois por cento de biodiesel ao óleo diesel, sobre o cultivo de oleaginosas a serem utilizadas na fabricação de biodiesel e sobre a sua produção e comercialização

O Congresso Nacional decreta:

Art. 1 É fixado em dois por cento o percentual mínimo obrigatório de adição de biodiesel ao óleo diesel vendido ao consumidor final, em todo o território nacional.

$\S 1^{\circ} \quad$ Para fins desta Lei, biodiesel é um aditivo para motores de combustão interna com ignição por compressão, renovável e biodegradável, derivado de óleos de plantas agrícolas ou de gorduras animais e que atenda à especificação técnica da Agência Nacional do Petróleo ANP.

$\S 2^{\circ}$ O Poder Executivo pode elevar o percentual definido no caput deste artigo para, no máximo, de cinco por cento.

$\S 3^{\circ} \quad$ É admitida a variação de dois décimos por cento, para mais ou para menos, na aferição dos percentuais de que trata este artigo.

$\S 4^{\circ} \quad$ A ANP, em razão do percentual de adição do biodiesel ao óleo diesel, deve estabelecer novo teor máximo de enxofre para esse combustível.

Art. 2 As unidades familiares que cultivem oleaginosas com capacidade de produção de até cem toneladas por ano de óleo vegetal e que se enquadrem no critério de agricultura familiar podem formar cooperativas ou associações de pequenos agricultores.

Art. 3 A atividade de produção incentivada nesta Lei consiste na fabricação de biodiesel em cooperativas ou associações de pequenos agricultores definidos no art. $2^{\circ}$, com capacidade de produção de até cinqüenta mil litros por dia, em estabelecimento denominado cooperativa ou associação de pequenos agricultores para produção de biodiesel. 
Parágrafo único. As cooperativas ou associações de pequenos agricultores para a produção de biodiesel, mencionadas no caput deste artigo, somente podem entrar em operação mediante prévia autorização da ANP e do órgão competente integrante do Sistema Nacional do Meio Ambiente - SISNAMA.

Art. 4 Não incide tributos federais sobre toda a cadeia de produção e comercialização de biodiesel produzido pelas cooperativas ou associações de pequenos agricultores definidas no art. $3^{\circ}$.

Art. 5 Pelo menos cinqüenta por cento do biodiesel necessário ao atendimento dos percentuais estabelecidos no art. $1^{\circ}$ tem que ser produzido por cooperativas ou associações de pequenos agricultores para produção de biodiesel, conforme art. $3^{\circ}$, instaladas nas Regiões Norte, Nordeste e Centro-Oeste.

Art. 6 A atividade de produção e comercialização de biodiesel puro pode ser exercida por cooperativa ou associação de pequenos agricultores constituída sob as leis brasileiras que atender, em caráter permanente, aos seguintes requisitos:

I - possuir registro de cooperativa ou associação de pequenos agricultores para produção de biodiesel expedido pela ANP; e

II - dispor de instalações de processamento, tancagem para armazenamento e equipamento medidor de biodiesel.

Art. 7 A construção das instalações e a tancagem da cooperativa ou associação de produtores deve observar as normas técnicas e os regulamentos aplicáveis.

Parágrafo único. A construção a que se refere este artigo prescinde de autorização da ANP.

Art. 8 O Banco do Brasil S.A., o Banco do Nordeste do Brasil S.A. e o Banco da Amazônia S.A. devem criar linhas de crédito específicas para o cultivo de oleaginosas pelas unidades familiares definidas no art. $2^{\circ}$.

Art. 9 O Banco Nacional de Desenvolvimento Econômico e Social - BNDES deve criar linha de crédito específica para o financiamento das instalações das cooperativas ou associações de pequenos agricultores definidas no art. $3^{\circ}$.

Art. 10. O prazo para aplicação do disposto no art. $1^{\circ}$ é de 2 anos após a publicação desta lei.

Art. 11. Esta Lei entra em vigor na data de sua publicação. 


\section{JUSTIFICAÇÃO}

Num momento em que o todo o País dá mostras de sua preocupação com a inclusão social, com a melhoria da qualidade de vida de seus cidadãos e com a conservação do meio ambiente, faz-se mister adaptar as atividades econômicas brasileiras a essa nova realidade.

Os combustíveis dito convencionais, de origem fóssil, contribuem significativamente para o aumento da poluição do meio ambiente. Os derivados de petróleo e o carvão alimentam grandes setores da economia atual, como a própria geração de energia, a produção industrial e o transporte, totalizando aproximadamente noventa por cento da energia comercial utilizada no mundo. A queima desses combustíveis lança na atmosfera mais de seis bilhões de toneladas de dióxido de carbono por ano.

O óleo diesel é, atualmente, o derivado de petróleo mais consumido no Brasil e, considerando o perfil de produção das refinarias brasileiras, uma fração crescente desse produto vem sendo importada. Nossa importação anual de óleo diesel é de cerca de quarenta milhões de barris, gerando uma despesa de cerca de 1,2 bilhão de dólares na nossa balança de pagamentos. Tendo-se em conta o potencial agrícola brasileiro e os condicionantes ambientais mundiais, torna-se oportuno discutir a produção de fontes alternativas de energia, ecologicamente sustentáveis, para esse derivado de petróleo.

No Brasil, o biodiesel, apesar da grande solução que pode representar como aditivo para o óleo diesel, ainda não passa de uma auspiciosa promessa. Em países como Alemanha, França e Estados Unidos, o biodiesel já é uma realidade.

Biodiesel é uma denominação genérica de combustíveis para motores de combustão interna com ignição por compressão, derivados de fontes renováveis, como óleos de dendê, soja, palma e mamona. O Brasil foi pioneiro em pesquisas sobre biodiesel com os trabalhos do professor Expedito Parente, da Universidade Federal do Ceará. O professor Expedito é autor da patente PI - 8007957, primeira patente, em termos mundiais, do biodiesel e do querosene vegetal de aviação, já de domínio público.

Comparado ao óleo diesel derivado de petróleo, o biodiesel puro reduz em até setenta e oito por cento as emissões de gás carbônico, considerando-se a reabsorção pelas plantas. Além disso, reduz em noventa por cento as emissões de fumaça e praticamente elimina as emissões 
de óxido de enxofre. O biodiesel pode ser usado em qualquer motor de ciclo Diesel, com pouca ou nenhuma necessidade de adaptação.

O biodiesel pode ser considerado um excelente aditivo verde para o óleo diesel, pois ele pode desempenhar o papel que o enxofre desempenha no aumento da lubricidade do óleo diesel. O biodiesel pode viabilizar a utilização de óleos diesel com baixíssimo teor de enxofre.

As propriedades lubrificantes do óleo diesel são importantes para os equipamentos de injeção do combustível, tais como injetores e bombas. Combustíveis de baixa lubricidade aumentam o desgaste e reduzem a vida útil dos componentes. Esse problema será ainda maior quando as especificações estabelecerem reduções adicionais do teor de enxofre do óleo diesel.

Testes comprovam que a adição de $2 \%$ de biodiesel ao óleo diesel será suficiente para atingir a lubricidade hoje existente. Acrescente-se que se mais biodiesel for adicionado, não haverá nenhuma conseqüência adversa para os motores.

Os Deputados Membros do Conselho de Altos Estudos e Avaliação Tecnológica da Câmara dos Deputados, após terem debatido amplamente a questão, inclusive com a colaboração de pesquisadores e especialistas nas diversas áreas que abrangem o tema, apresentam agora este Projeto de Lei, certos de que ele poderá trazer grandes contribuições não apenas para a matriz energética do país, mas também para seu desenvolvimento social.

O projeto de lei em comento estabelece a obrigatoriedade da adição de $2 \%$ de biodiesel ao óleo diesel. Dispõe, ainda, que haverá total isenção de tributos federais no caso do biodiesel ser fabricado a partir de oleaginosas cultivadas por unidades familiares, que cultivem plantas com capacidade de produzir até 100 toneladas por ano de óleo vegetal, agrupados em cooperativas ou associações de pequenos agricultores para produção de biodiesel, com capacidade de produção de até 50.000 litros por dia. Essa renúncia fiscal é tão pequena que está dentro da margem de incerteza da previsão de receitas e despesas do orçamento da União.

É criada, ainda, uma reserva de mercado, pois as empresas distribuidoras de combustível terão que comprar $50 \%$ do biodiesel, para atender o percentual de mistura com o óleo diesel exigido pelo presente Projeto, de pequenos produtores das regiões Norte, Nordeste e Centro-Oeste. Ressalte-se que a Constituição Federal permite, até mesmo, a concessão de incentivos fiscais diferenciados destinados a promover o equilíbrio do desenvolvimento socioeconômico entre as diferentes regiões do País. 
O projeto prevê também a criação, pelo Banco do Brasil, pelo Banco do Nordeste do Brasil e pelo Banco da Amazônia de uma linha de crédito específica para o financiamento do plantio de oleaginosas por unidades familiares e de uma linha de crédito, pelo Banco Nacional de Desenvolvimento Econômico e Social - BNDES, para instalação de cooperativas de pequenos agricultores. Nada mais justo que haja financiamento governamental, visto o grande alcance social do projeto e as altas taxas de juro praticadas pelo sistema financeiro nacional.

A Lei $n^{0} 9.847$, de 1999 , estabelece, em seu art. $1^{\circ}$, que a fiscalização das atividades relativas ao abastecimento nacional de combustíveis será realizada pela ANP ou mediante convênios por ela celebrados e que esse abastecimento abrange as atividades de distribuição, revenda e comercialização.

Acrescente-se que o art. $8^{\circ}$ dessa lei, que dispõe sobre a finalidade da ANP, restringese às atividades econômicas integrantes da indústria do petróleo. Depreende-se, então, que as atividades de regulação, contratação e fiscalização da produção de biocombustíveis está por exigir uma lei específica.

O projeto de lei ora proposto ensejará uma nova norma regulamentar da ANP para regular as atividades referentes ao biodiesel e às cooperativas de pequenos agricultores. A criação, regulação e fiscalização desse novo ente, a cooperativa de pequenos agricultores, não é tarefa fácil. Entretanto, a ANP, consciente de sua nobre função de agência estatal, definirá com rigor e precisão as medidas a serem adotadas para garantir um fornecimento de qualidade por parte dessas cooperativas.

Este projeto pode significar a criação de emprego e renda para milhares de excluídos das regiões mais carentes do País, a sustentabilidade da agricultura familiar e do pequeno agronegócio local para fins energéticos, além da melhoria do meio ambiente.

Sala das Sessões, em de 2004.

\author{
Deputado Ariosto Holanda (PSDB-CE) \\ Deputado Luiz Piauhylino (PTB-PE) \\ Deputado Félix Mendonça (PFL-BA) \\ Deputado Gilmar Machado (PT-MG) \\ Deputado João Paulo Gomes da Silva (PL-MG) \\ Deputado José Ivo Sartori (PMDB-RS)
}


Deputado José Linhares (PP-CE)

Deputado Luiz Carreira (PFL-BA)

Deputada Luiza Erundina (PSB-SP)

Deputado Marcondes Gadelha (PTB-PB)

Deputada Telma de Souza (PT-SP)

Deputado Luiz Bittencourt (PMDB-GO) 


\section{ANEXO 2}

Lei $\mathbf{N}^{0}$ 11.097, de 13 de janeiro de 2005 - Dispõe sobre a introdução do biodiesel na matriz energética brasileira; altera as Leis $\mathrm{n}^{\text {os }}$ 9.478, de 6 de agosto de 1997, 9.847 de 26 de outubro de 1999 e 10.636, de 30 de dezembro de 2002 e dá outras providências 


\section{Senado Federal \\ Subsecretaria de Informações \\ LEI No 11.097, DE 13 DE JANEIRO DE 2005}

Dispõe sobre a introdução do biodiesel na matriz energética brasileira; altera as Leis $\mathbf{n}^{\mathbf{0}} \mathbf{S}$ 9.478, de 6 de agosto de 1997, 9.847, de 26 de outubro de 1999 e 10.636, de 30 de dezembro de 2002; e dá outras providências.

O PRESIDENTE DA REPÚBLICA Faço saber que o Congresso Nacional decreta e eu sanciono a seguinte Lei:

Art. $1^{\circ} \mathrm{O}$ art. $1^{\circ}$ da Lei $\mathrm{n}^{\circ} 9.478$, de 6 de agosto de 1997, passa a vigorar acrescido do inciso XII, com a seguinte redação:

"Art. $1^{\circ}$

XII - incrementar, em bases econômicas, sociais e ambientais, a participação dos biocombustíveis na matriz energética nacional." (NR)

Art. $2^{\circ}$ Fica introduzido o biodiesel na matriz energética brasileira, sendo fixado em $5 \%$ (cinco por cento), em volume, o percentual mínimo obrigatório de adição de biodiesel ao óleo diesel comercializado ao consumidor final, em qualquer parte do território nacional.

$\S 1^{\circ} \mathrm{O}$ prazo para aplicação do disposto no caput deste artigo é de 8 (oito) anos após a publicação desta Lei, sendo de 3 (três) anos o período, após essa publicação, para se utilizar um percentual mínimo obrigatório intermediário de $2 \%$ (dois por cento), em volume.

$\S 2^{\circ}$ Os prazos para atendimento do percentual mínimo obrigatório de que trata este artigo podem ser reduzidos em razão de resolução do Conselho Nacional de Política Energética - CNPE, observados os seguintes critérios:

I - a disponibilidade de oferta de matéria-prima e a capacidade industrial para produção de biodiesel;

II - a participação da agricultura familiar na oferta de matérias-primas;

III - a redução das desigualdades regionais;

IV - o desempenho dos motores com a utilização do combustível;

$\mathrm{V}$ - as políticas industriais e de inovação tecnológica. 
$\S 3^{\circ}$ Caberá à Agência Nacional do Petróleo, Gás Natural e Biocombustíveis - ANP definir os limites de variação admissíveis para efeito de medição e aferição dos percentuais de que trata este artigo.

$\S 4^{\circ} \mathrm{O}$ biodiesel necessário ao atendimentos dos percentuais mencionados no caput deste artigo terá de ser processado, preferencialmente, a partir de matérias-primas processadas por agricultor familiar, inclusive resultante de atividade extrativista. (Incluído pela Lei 11.116, de 2005).

Art. $3^{\circ} \mathrm{O}$ inciso IV do art. $2^{\circ}$ da Lei $\mathrm{n}^{\circ}$ 9.478, de 6 de agosto de 1997, passa a vigorar com a seguinte redação:

"Art. $2^{\circ}$

IV - estabelecer diretrizes para programas específicos, como os de uso do gás natural, do carvão, da energia termonuclear, dos biocombustíveis, da energia solar, da energia eólica e da energia proveniente de outras fontes alternativas; ." (NR)

Art. $4^{\circ} \mathrm{O}$ art. $6^{\circ}$ da Lei $\mathrm{n}^{\circ}$ 9.478, de 6 de agosto de 1997, passa a vigorar acrescido dos incisos XXIV e XXV, com a seguinte redação:

"Art. $6^{\circ}$

XXIV - Biocombustível: combustível derivado de biomassa renovável para uso em motores a combustão interna ou, conforme regulamento, para outro tipo de geração de energia, que possa substituir parcial ou totalmente combustíveis de origem fóssil;

XXV - Biodiesel: biocombustível derivado de biomassa renovável para uso em motores a combustão interna com ignição por compressão ou, conforme regulamento, para geração de outro tipo de energia, que possa substituir parcial ou totalmente combustíveis de origem fóssil." (NR)

Art. $5^{\circ}$ O Capítulo IV e o caput do art. $7^{\circ}$ da Lei $n^{\circ} 9.478$, de 6 de agosto de 1997, passam a vigorar com a seguinte redação:

"CAPÍTULO IV

DA AGÊNCIA NACIONAL DO PETRÓLEO, GÁS NATURAL E BIOCOMBUSTÍVEIS 
Art. $7^{\circ}$ Fica instituída a Agência Nacional do Petróleo, Gás Natural e Biocombustíves - ANP, entidade integrante da Administração Federal Indireta, submetida ao regime autárquico especial, como órgão regulador da indústria do petróleo, gás natural, seus derivados e biocombustíveis, vinculada ao Ministério de Minas e Energia.

(NR)

Art. $6^{\circ} \mathrm{O}$ art. $8^{\circ}$ da Lei $\mathrm{n}^{\circ} 9.478$, de 6 de agosto de 1997, passa a vigorar com a seguinte redação:

"Art. $8^{\circ}$ A ANP terá como finalidade promover a regulação, a contratação e a fiscalização das atividades econômicas integrantes da indústria do petróleo, do gás natural e dos biocombustíveis, cabendo-lhe:

I - implementar, em sua esfera de atribuições, a política nacional de petróleo, gás natural e biocombustíveis, contida na política energética nacional, nos termos do Capítulo I desta Lei, com ênfase na garantia do suprimento de derivados de petróleo, gás natural e seus derivados, e de biocombustíveis, em todo o território nacional, e na proteção dos interesses dos consumidores quanto a preço, qualidade e oferta dos produtos;

VII - fiscalizar diretamente, ou mediante convênios com órgãos dos Estados e do Distrito Federal, as atividades integrantes da indústria do petróleo, do gás natural e dos biocombustíveis, bem como aplicar as sanções administrativas e pecuniárias previstas em lei, regulamento ou contrato;

IX - fazer cumprir as boas práticas de conservação e uso racional do petróleo, gás natural, seus derivados e biocombustíveis e de preservação do meio ambiente;

XI - organizar e manter o acervo das informações e dados técnicos relativos às atividades reguladas da indústria do petróleo, do gás natural e dos biocombustíveis;

XVI - regular e autorizar as atividades relacionadas à produção, importação, exportação, armazenagem, estocagem, distribuição, revenda e comercialização de biodiesel, fiscalizandoas diretamente ou mediante convênios com outros órgãos da União, Estados, Distrito Federal ou Municípios; 
XVII - exigir dos agentes regulados o envio de informações relativas às operações de produção, importação, exportação, refino, beneficiamento, tratamento, processamento, transporte, transferência, armazenagem, estocagem, distribuição, revenda, destinação e comercialização de produtos sujeitos à sua regulação;

XVIII - especificar a qualidade dos derivados de petróleo, gás natural e seus derivados e dos biocombustíveis." (NR)

Art. $7^{\circ}$ A alínea d do inciso I e a alínea f do inciso II do art. 49 da Lei $n^{\circ} 9.478$, de 6 de agosto de 1997, passam a vigorar com a seguinte redação:

"Art. 49.

I -

d) $25 \%$ (vinte e cinco por cento) ao Ministério da Ciência e Tecnologia, para financiar programas de amparo à pesquisa científica e ao desenvolvimento tecnológico aplicados à indústria do petróleo, do gás natural e dos biocombustíveis;

II -

f) $25 \%$ (vinte e cinco por cento) ao Ministério da Ciência e Tecnologia, para financiar programas de amparo à pesquisa científica e ao desenvolvimento tecnológico aplicados à indústria do petróleo, do gás natural e dos biocombustíveis. " (NR)

Art. $8^{\circ} \mathrm{O} \S 1^{\circ}$ do art. $1^{\circ}$ da Lei $n^{\circ} 9.847$, de 26 de outubro de 1999 , passa a vigorar com a seguinte redação:

"Art. $1^{\circ}$

$\S 1^{\circ} \mathrm{O}$ abastecimento nacional de combustíveis é considerado de utilidade pública e abrange as seguintes atividades:

I - produção, importação, exportação, refino, beneficiamento, tratamento, processamento, transporte, transferência, armazenagem, estocagem, distribuição, revenda, comercialização, avaliação de conformidade e certificação do petróleo, gás natural e seus derivados;

II - produção, importação, exportação, armazenagem, estocagem, distribuição, revenda, comercialização, avaliação de conformidade e certificação do biodiesel;

III - comercialização, distribuição, revenda e controle de qualidade de álcool etílico combustível. 
Art. $9^{\circ}$ Os incisos II, VI, VII, XI e XVIII do art. $3^{\circ}$ da Lei ${ }^{\circ} 9.847$, de 26 de outubro de 1999, passam a vigorar com a seguinte redação:

"Art. $3^{\circ}$

II - importar, exportar ou comercializar petróleo, gás natural, seus derivados e biocombustíveis em quantidade ou especificação diversa da autorizada, bem como dar ao produto destinação não permitida ou diversa da autorizada, na forma prevista na legislação aplicável:

Multa - de R \$ 20.000,00 (vinte mil reais) a R \$ 5.000.000,00 (cinco milhões de reais);

VI - não apresentar, na forma e no prazo estabelecidos na legislação aplicável ou, na sua ausência, no prazo de 48 (quarenta e oito) horas, os documentos comprobatórios de produção, importação, exportação, refino, beneficiamento, tratamento, processamento, transporte, transferência, armazenagem, estocagem, distribuição, revenda, destinação e comercialização de petróleo, gás natural, seus derivados e biocombustíveis:

Multa - de R \$ 20.000,00 (vinte mil reais) a R \$ 1.000.000,00 (um milhão de reais);

VII - prestar declarações ou informações inverídicas, falsificar, adulterar, inutilizar, simular ou alterar registros e escrituração de livros e outros documentos exigidos na legislação aplicável, para o fim de receber indevidamente valores a título de benefício fiscal ou tributário, subsídio, ressarcimento de frete, despesas de transferência, estocagem e comercialização:

Multa - de R \$500.000,00 (quinhentos mil reais) a R \$ 5.000.000,00 (cinco milhões de reais);

XI - importar, exportar e comercializar petróleo, gás natural, seus derivados e biocombustíveis fora de especificações técnicas, com vícios de qualidade ou quantidade, inclusive aqueles decorrentes da disparidade com as indicações constantes do recipiente, da embalagem ou rotulagem, que os tornem impróprios ou inadequados ao consumo a que se destinam ou lhes diminuam o valor:

Multa - de R \$ 20.000,00 (vinte mil reais) a R \$ 5.000.000,00 (cinco milhões de reais);

XVIII - não dispor de equipamentos necessários à verificação da qualidade, quantidade estocada e comercializada dos produtos derivados de petróleo, do gás natural e seus derivados, e dos biocombustíveis: 
Multa - de $\mathrm{R} \$ 5.000,00$ (cinco mil reais) a $\mathrm{R} \$ 50.000,00$ (cinqüenta mil reais)." (NR)

Art. 10. O art. $3^{\circ}$ da Lei $n^{\circ} 9.847$, de 26 de outubro de 1999, passa a vigorar acrescido do seguinte inciso XIX:

"Art. $3^{\circ}$

XIX - não enviar, na forma e no prazo estabelecidos na legislação aplicável, as informações mensais sobre suas atividades:

Multa - de R $\$ 20.000,00$ (vinte mil reais) a R \$ 1.000.000,00 (um milhão de reais)." (NR)

Art. 11. O art. $5^{\circ}$ da Lei $\mathrm{n}^{\circ}$ 9.847, de 26 de outubro de 1999, passa a vigorar com a seguinte redação:

"Art. $5^{\circ}$ Sem prejuízo da aplicação de outras sanções administrativas, a fiscalização poderá, como medida cautelar:

I - interditar, total ou parcialmente, as instalações e equipamentos utilizados se ocorrer exercício de atividade relativa à indústria do petróleo, gás natural, seus derivados e biocombustíveis sem a autorização exigida na legislação aplicável;

II - interditar, total ou parcialmente, as instalações e equipamentos utilizados diretamente no exercício da atividade se o titular, depois de outorgada a autorização, concessão ou registro, por qualquer razão deixar de atender a alguma das condições requeridas para a outorga, pelo tempo em que perdurarem os motivos que deram ensejo à interdição;

III - interditar, total ou parcialmente, nos casos previstos nos incisos II, VI, VII, VIII, IX, XI e XIII do art. $3^{\circ}$ desta Lei, as instalações e equipamentos utilizados diretamente no exercício da atividade outorgada;

IV - apreender bens e produtos, nos casos previstos nos incisos I, II, VI, VII, VIII, IX, XI e XIII do art. $3^{\circ}$ desta Lei. ." (NR)

Art. 12. O art. 11 da Lei $\mathrm{n}^{\circ}$ 9.847, de 26 de outubro de 1999, passa a vigorar acrescido do seguinte inciso $\mathrm{V}$ :

"Art. 11. A penalidade de perdimento de produtos apreendidos na forma do art. $5^{\circ}$, inciso IV, desta Lei, será aplicada quando:

V - o produto apreendido não tiver comprovação de origem por meio de nota fiscal. 
Art. 13. O caput do art. 18 da Lei $\mathrm{n}^{\circ}$ 9.847, de 26 de outubro de 1999, passa a vigorar com a seguinte redação:

"Art. 18. Os fornecedores e transportadores de petróleo, gás natural, seus derivados e biocombustíveis respondem solidariamente pelos vícios de qualidade ou quantidade, inclusive aqueles decorrentes da disparidade com as indicações constantes do recipiente, da embalagem ou rotulagem, que os tornem impróprios ou inadequados ao consumo a que se destinam ou lhes diminuam o valor.

". (NR)

Art. 14. O art. 19 da Lei $n^{\circ} 9.847$, de 26 de outubro de 1999, passa a vigorar com a seguinte redação:

"Art. 19. Para os efeitos do disposto nesta Lei, poderá ser exigida a documentação comprobatória de produção, importação, exportação, refino, beneficiamento, tratamento, processamento, transporte, transferência, armazenagem, estocagem, distribuição, revenda, destinação e comercialização dos produtos sujeitos à regulação pela ANP." (NR)

Art. $15 . \mathrm{O}$ art. $4^{\circ}$ da Lei $\mathrm{n}^{\circ} 10.636$, de 30 de dezembro de 2002, passa a vigorar acrescido do seguinte inciso VII:

"Art. $4^{\circ}$

VII - o fomento a projetos voltados à produção de biocombustíveis, com foco na redução dos poluentes relacionados com a indústria de petróleo, gás natural e seus derivados. ." (NR)

Art. 16. (VETADO)

Art. 17. (VETADO)

Art. 18. Esta Lei entra em vigor na data de sua publicação.

Brasília, 13 de janeiro de 2005; $184^{\circ}$ da Independência e $117^{\circ}$ da República.

\section{LUIZ INÁCIO LULA DA SILVA}

Luiz Paulo Teles Ferreira Barreto

Dilma Vana Rousseff 